UNIVERSIDADE DE SÃO PAULO

FACULDADE DE FILOSOFIA, LETRAS E CIÊNCIAS HUMANAS

DEPARTAMENTO DE GEOGRAFIA

PROGRAMA DE PÓS-GRADUAÇÃO EM GEOGRAFIA HUMANA

VIVIANE ALVES VIEIRA

Os reassentamentos da Vale em Moçambique: um estudo sobre mobilização do trabalho e trabalho supérfluo

VERSÃO CORRIGIDA 


\author{
UNIVERSIDADE DE SÃO PAULO \\ FACULDADE DE FILOSOFIA, LETRAS E CIÊNCIAS HUMANAS \\ DEPARTAMENTO DE GEOGRAFIA \\ PROGRAMA DE PÓS-GRADUAÇÃO EM GEOGRAFIA HUMANA
}

\title{
Os reassentamentos da Vale em Moçambique: um estudo sobre mobilização do trabalho e trabalho supérfluo
}

\author{
Viviane Alves Vieira
}

\begin{abstract}
Dissertação apresentada ao Programa de pós-graduação em Geografia Humana da Faculdade de Filosofia, Letras e Ciências Humanas da Universidade de São Paulo, para obtenção do título de Mestra em Geografia.
\end{abstract}

Orientador: Prof. Dr. Carlos de Almeida Toledo

VERSÃO CORRIGIDA 
Autorizo a reprodução e divulgação total ou parcial deste trabalho, por qualquer meio convencional ou eletrônico, para fins de estudo e pesquisa, desde que citada a fonte.

Catalogação na Publicação

Serviço de Biblioteca e Documentação

Faculdade de Filosofia, Letras e Ciências Humanas da Universidade de São Paulo

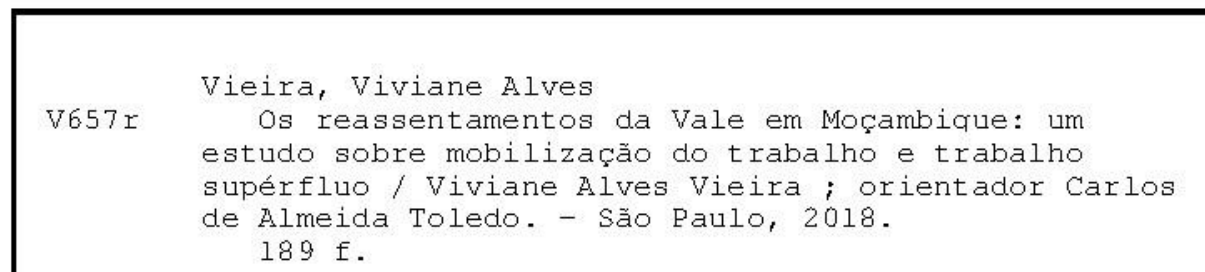

1. Expropriaçäo. 2. Mineração. 3. Mobilidade do trabalho. 4. Brasil - Moçambique. 5. Crise do

trabalho. I. Toledo, Carlos de Almeida, orient. II.

Título. 
ENTREGA DO EXEMPLAR CORRIGIDO DA DISSERTACÃO/TESE

Termo de Ciência e Concordância do (a) orientador (a)

Nome do (a) aluno (a): Viviane Alves Vieira

Data da defesa: $26 / 02 / 2019$

Nome do Prof. (a) orientador (a): Carlos de Almeida Toledo

Nos termos da legislação vigente, declaro ESTAR CIENTE do conteúdo deste EXEMPLAR CORRIGIDO elaborado em atenção às sugestões dos membros da comissão Julgadora na sessão de defesa do trabalho, manifestando-me plenamente favorável ao seu encaminhamento e publicação no Portal Digital de Teses da USP.

São Paulo, 25/04/2019

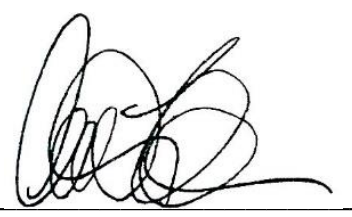

Prof. Dr. Carlos de Almeida Toledo 


\section{RESUMO}

Essa pesquisa tem a finalidade de analisar o atual processo de mobilização e crise do trabalho no distrito de Moatize, em Moçambique, a partir da mineração e seus conflitos consequentes dessa atividade. Para isso retomamos a formação da relação capital-trabalho para compreendermos os aspectos da crise dessa relação. O processo de modernização das forças produtivas provocou uma mudança histórica no setor e, em Moçambique, é possível de ser narrada por duas gerações de trabalhadores que acompanharam a produção de carvão mineral. Baseamo-nos em estudos, dados do distrito e relatos de moradores, principalmente de dois reassentamentos: Cateme e 25 de setembro, provocados pela expansão das atividades da mineradora Vale S/A para Moçambique. Nesses reassentamentos muitos dos moradores narraram o processo de mobilização para o trabalho no período colonial e pós colonial, cuja extração do carvão mineral no distrito era feita em galerias subterrâneas. A mudança na técnica de exploração levou à extração à céu aberto o que colocou o conflito pela remoção das pessoas que viviam na área em que o Estado concedeu à multinacional. A extração do carvão avança rapidamente a área de exploração e consequentemente acentuou o processo de expropriação em Moçambique com a perda das áreas para a produção de alimentos. Contraditoriamente, o processo requer menos trabalho humano e coloca limitações para a força de trabalho que deve ser especializada, provocando um desemprego estrutural ou ainda os supérfluos ao sistema, nesse caso os próprios moradores dos reassentamentos. O limite da relação pode ser pensado ainda pela totalidade do processo de acumulação capitalista em que o aumento nos níveis de produtividade se faz necessário pela concorrência no setor e ao mesmo tempo coloca a necessidade de aumento de consumo da mercadoria, pois para realizar o valor, a mercadoria precisa ser comprada. No entanto, o próprio mercado mostra ter um limite.

Palavras-chave: mineração, mobilidade do trabalho, expropriação, Brasil-Moçambique, crise do trabalho 


\begin{abstract}
This research has the purpose of analyzing the current process of mobilization and labor crisis in the district of Moatize, in Mozambique, from the mining and its consequent conflicts of this activity. We have recurred the capital-labor relationship formation to understand the crisis aspects of this relationship. The modernization process of the productive forces has brought about a historic change in the sector and in Mozambique it can be narrated for two generations by the experience of coal production. We are based on studies, district data and residents' stories, mainly of two resettlements caused by the expansion of the activities of Vale S/A to Mozambique. In these resettlements many of the villagers recounted the process of mobilization for labor in the colonial and postcolonial period, whose extraction of mineral coal in the district was done in underground galleries. The change in the technique of exploration led to the extraction in the open which put the conflict by the removal of the people who lived in the area in which the State granted to the multinational. Extraction of coal rapidly advances the exploitation area and consequently has accentuated the expropriation process in Mozambique causing the loss of areas for food production. In contrast, the process requires less human labor and some limitations for the workforce that must be specialized, causing structural unemployment or even the superfluous to the system, in this case the residents themselves of the resettlement. The limit of the relationship can still be thought of by the totality of the process in which the increase in the levels of productivity is made necessary by the market competition in the sector and at the same time places the need to increase consumption of the merchandise, because to realize the value, the merchandise needs be purchased. However, the market itself shows a limit.
\end{abstract}

Keywords: mining, labor mobility, expropriation, Brazil-Mozambique, crisis of labor 


\section{AGRADECIMENTOS}

Essa pesquisa envolve muitas pessoas e de diferentes lugares. Sou imensamente grata a quem foi minha rede de apoio durante esse período. A quem incentivou, questionou, me indicou leituras, quem me ensinou a caminhar nos meandros acadêmicos da pós graduação... e a quem deu condições para que essa pesquisa acontecesse.

À meu orientador Carlos de Almeida Toledo, Carlão. Desde a graduação acolheu e impulsionou a ideia da pesquisa, sempre me encorajou e tentou me tirar do meu processo de estudar solitário, me mostrando como é estudar em grupo ao me abrir as portas dos grupos no Labur. Grata pelas conversas, leituras e apontamentos e por tornar o processo de pesquisa mais leve.

À Marta Jardim. Foi incrível aprender sobre Moçambique com você aqui em São Paulo. Sou grata pelas memórias-afetivas-gastronômicas-moçambicanas, às aulas de suahili, pelas indicações de leituras e a forma carinhosa com que leu e deu apontamentos em meu texto... sempre faz Moçambique e o que ele representa permanecer vivo.

Aos grupos de estudos no Labur. Foi de grande aprendizado e me ajudou demais quando eu não sabia onde acomodar ideias que estavam agitadas na minha cabeça. Boa parte do que aqui escrevi tem base nas discussões nos grupos, questões coletivas que atravessam muitas de nossas pesquisas: Ceci, Clara, Mari, Pedro, Olívia, Felipe, Daniel, Rafa, Fábio, Cássio, Carol, Erick, Ana, Daniel, Allan. Ceci e Clara agradeço também por, numa rápida conversa enquanto eu estava em campo, terem me trazido de volta para a discussão quando eu estava com a cabeça fervendo, foi coisa rápida, mas bastante importante para mim. Ana e Allan por terem lido e dado bons apontamentos no texto, foram muito generosos e tive com isso um sentido maior sobre o processo coletivo de pesquisa. Carol, por desde o TGI e passando pela qualificação ter me colocado questões e caminhos possíveis de conversa.

Agradeço a Luiz Henrique Passador pelos apontamentos bastante necessários na qualificação.

À família cruspiana, uma vizinhança de pesquisadores quase full time. Sou grata pelos cafés, bolos, almoços, cervejas, pandeiro e violão. Obrigada pelas conversas sobre raça, gênero, classe entre quem está na periferia dessa Universidade, por permitirem conhecer mais sobre a pesquisa de vocês e acompanhar os bastidores. Por dividir sobre o prazer e a dificuldade que é estudar e principalmente escrever, cotidianamente. Agradeço sobretudo à Patrícia Anette (que bom esse reencontro!) que me mostrou o lado das Letras 
e me fez pensar sobre a prática da escrita e Denise Piccirillo que fez os mapas que estão em anexo nessa pesquisa.

Agradeço aos meus pais e minhas irmãs.

Aos amigos que, para não ser injusta não citarei os nomes, entenderam meu tempo de estudo e não insistiam, nem desistiram de mim e, muitas vezes sem saber, me tiraram da solidão acadêmica, trouxeram riso quando muitas vezes estava sendo também duro e pesado.

Marina pela ajuda no abstract! E à querida Vitória, você foi muito importante principalmente enquanto eu estava fazendo pesquisa de campo.

Aos amigos e pesquisadores que fizeram a travessia atlântica em algum momento: Vic, Fabiano, Gabi, Mariana, Marina, Vanessa, Malu, Josi, Letícia, Bruna, Rosa. Vou agradecendo e relembrando quantos encontros incríveis, conversas sobre nossos estranhamentos e encantamentos por Moçambique que nos fazem sempre ter vontade de voltar. Tive sorte em conhecer pesquisadores com variados temas sobre o mesmo país em que somos estrangeiros.

E do outro lado do oceano... Sou grata a Marílio, Joana, Micol, Davide, Magda, Vasco, Delícia, Ivan, e tantos outros que tornaram Maputo ainda mais afetuosa e com quem aprendi muito sobre Moçambique. Jeremias obrigada por ter compartilhado suas causas de luta no país.

Com Carmem a minha gratidão é imensa. Agradeço por ter me apresentado sua família que me acolheu com tanto apreço em Tete. Muito obrigada Maria e Antunes por me receberem na casa de vocês. E Maria permitiu-me ainda ser acolhida em Nampula! Ao menino Jey, Tininha, dona Maria, lembrarei sempre com carinho. Ao Sr. Hunguana e à senhora Tina agradeço por terem me dado o privilégio de conhecer as valiosas histórias que tem e que guardam sobre Moatize.

Ao Sr. Pinho, Sr. Delvino, Sr. Jesse e à Maria Cebola, membros de associações em Moatize. Vocês me deram condições de ir às comunidades e compartilharam as causas que representam. Tenho por vocês gratidão e admiração. Ao senhor Camunga, Domingo, Daniel Dzimba, Armindo, Sérgio, Toneca... eu aprendi muito com vocês e agora que já nos conhecemos poderemos nos encontrar na outra vida.

Aos docentes da UEM que se disponibilizaram a conversas, apontaram parte da minha ingenuidade e me indicaram importantes leituras: Teresa Cruz e Silva, João Paulo Borges Coelho, Elmer Matos e principalmente à docente Inês Macamo Raimundo que recebeu-me. Muito obrigada! Agradeço da mesma forma à Conceição Osório da WLSA. 
Agradeço à FAPESP por ter financiado essa pesquisa por meio de bolsa de estudos. Processo 2016/ 05055-6. As opiniões, hipóteses e conclusões ou recomendações expressas neste material são de responsabilidade do (s) autor (es) e não necessariamente refletem a visão da FAPESP. 


\section{Lista de figuras}

Figura 1: Grupos étnicos entre os séculos XVI-XVIII ................................................. 29

Figura 2: Representação das Companhias - Economia colonial .................................... 44

Figura 3: Representação da área entre 1840 e 1902 ...................................................... 45

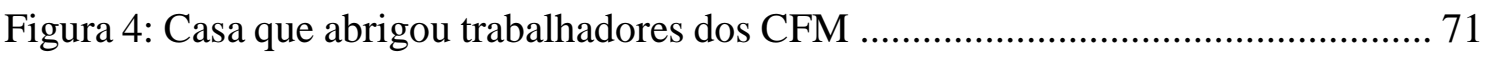

Figura 5: Venda de móveis na vila de Moatize ........................................................... 103

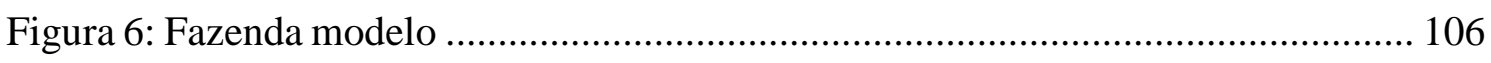

Figura 7: Reassentamento 25 de setembro - poluição ................................................ 108

Figura 8: Reassentamento 25 de setembro - casas .................................................. 109

Figura 9: Limite entre a comunidade e a área de exploração ...................................... 144

Figura 10: Limite entre reassentamento e condomínio dos funcionários da empresa ... 148

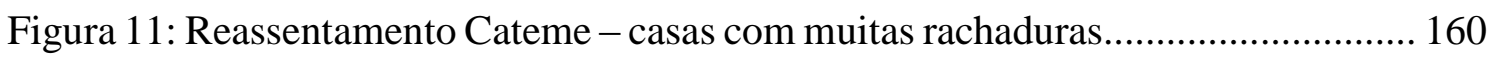

Figura 12: Venda de carvão vegetal próximo ao reassentamento Cateme ......................161

Figura 13: Reassentamento Cateme - casas sem telhados ......................................... 162

\section{Anexos}

I: Mapa administrativo de Moçambique

II: Mapa da Província de Tete, com destaque à Moatize e principais rios

III: Imagens aéreas de Moatize: 2005 - 2018

IV: Áreas de pesquisa, concessão e contrato de exploração mineral na Província de Tete

\section{Lista de siglas}

AAAJC: Associação de Apoio e Assistência Jurídica às Comunidades

ACFI: Acordo de Cooperação e Facilitação de Investimentos

AHM: Arquivo Histórico de Moçambique

BNDES: Banco Nacional de Desenvolvimento Econômico e Social

BRICS: Brasil, Rússia, Índia, China e África do Sul

CAPEMI: Comunidades Afetadas Pela Mineração e Indústria extrativa

CARBOMOC: Empresa Estatal Carbonífera de Moçambique

CEA: Centro de Estudos Africanos

CDE: Centro de Documentação Econômica

CFM: Caminhos de Ferro de Moçambique 
CIP: Centro de Integridade Pública

CLN: Corredor Logístico de Nacala

DUAT: Direito de Uso e Aproveitamento da Terra

EIA: Estudo de Impacto Ambiental

FIPAG: Fundo de Investimento e Patrimônio do Abastecimento de Água

FRELIMO: Frente de Libertação de Moçambique

IBAS: Fórum de Diálogo Índia - Brasil - África do Sul

ICVL: Internacional Coal Ventures Private Limited

IESE: Instituto de Estudos Sociais e Econômicos

IPEA: Instituto de Pesquisa Econômica Aplicada

MAE: Ministério da Administração Estatal

OMR: Observatório do Meio Rural

OP: Operação Produção

RAMBOG: Rede de Associações de Moatize para a Boa Governação

RDA: República Democrática Alemã

RDM: Rio Doce Moçambique

RENAMO: Resistência Nacional de Moçambique

RIMA: Relatório de Impacto Ambiental

SECH: Secretaria do Estado do Carvão e Hidrocarbonetos

SINTICIM: Sindicato Nacional dos Trabalhadores da Indústria de Construção Civil, Madeiras e Minas de Tete

UEM: Universidade Eduardo Mondlane

UNAC: União Nacional dos Camponeses

UPCT: União Provincial dos Camponeses de Tete

WENELA: Witwatersrand Native Labor Association

WLSA: Women and Law in Southern Africa Research and Education Trust 


\section{Sumário}

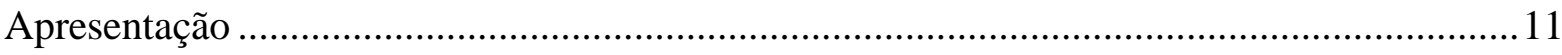

Capítulo 1: Entre fetiches e autoridades: formação do trabalho ............................................19

1.1. Os reassentamentos da Vale S/A: Cateme e 25 de Setembro: "Há problemas, não

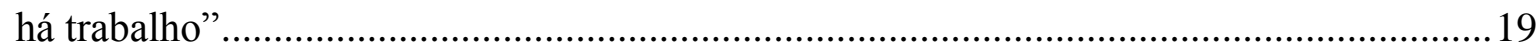

1.2. Relações de fetiche e o trabalho escravo na região do Vale do Zambeze ................27

1.3. O auge da colonização e do trabalho explicitamente forçado (chibalo) ....................41

1.4. A Companhia Carbonífera: "sim, havia trabalho!"..................................................61

1.5. CARBOMOC: Libertação e o trabalho no socialismo ..............................................78

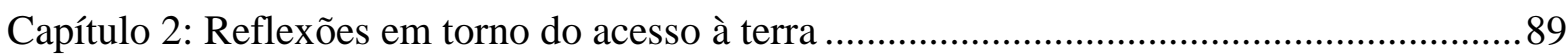

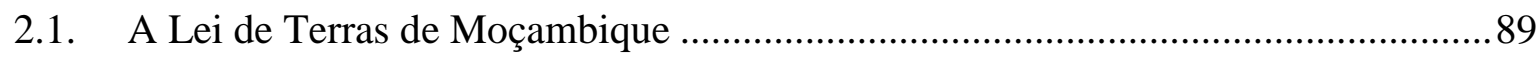

2.2. A divisão dos reassentamentos e o esfacelamento da unidade de produção e

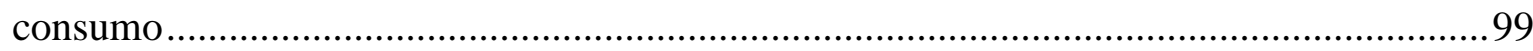

2.3. As mulheres dos reassentamentos: "não há machambas"....................................111

Capítulo 3: Mineradoras multinacionais e capital fictício .................................................. 122

3.1. A modernização pela forma da cooperação para o desenvolvimento..........................122

3.2. Uma solução à brasileira: A Vale S/A em Moçambique ........................................128

3.3. Período (da ilusão) do boom das matérias primas ................................................ 136

Capítulo 4: Desenvolvimento das forças produtivas e crise do trabalho ............................. 144

4.1. O desenvolvimento das forças produtivas e o trabalho especializado .........................144

4.2. “As pessoas não estão a trabalhar, estão a viver à maneira”. Supérfluos ................156

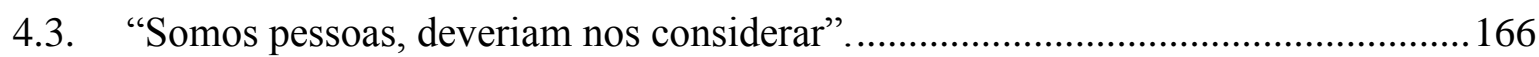

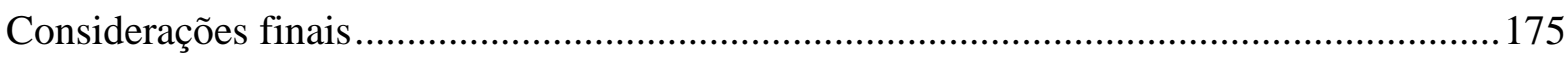

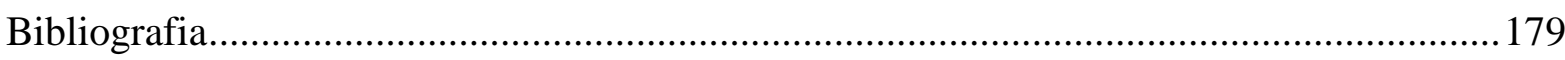

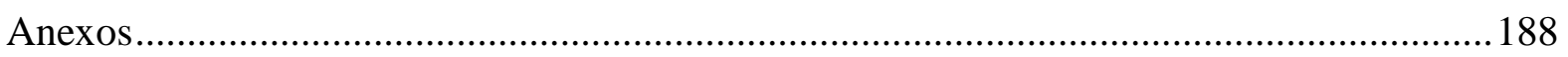




\section{Apresentação}

Essa pesquisa iniciou em 2014 durante a graduação quando fui pela primeira vez à Moçambique para fazer intercâmbio na Universidade Eduardo Mondlane. Nasceu no desejo de estudar e melhor compreender o processo histórico a partir de Moçambique, de estudar sobre relações do país africano no sistema capitalista e a perspectiva de autores moçambicanos. Em 2014, durante esse intercâmbio e quando acreditava que estava começando a conhecer o país, fui "desafiada" por moçambicanos a conhecer o "verdadeiro" Moçambique, a sair da capital cosmopolita Maputo, e assim colocaram-me a pensar sentido desse "verdadeiro". Estariam falando para eu sair da cidade e ir conhecer o campo? Pelas diferenças regionais e da multiplicidade do que constitui o país? Ir para onde o Estado é menos representado e o processo de territorialização do capital se manifesta por outras formas? A partir disso fui pela primeira vez para a Província de Tete, no centro do país, mas não aleatoriamente, pois Tete tinha uma questão que aproximava Moçambique do Brasil de uma forma contemporânea e era bastante noticiado pelos problemas dos reassentamentos causados pela mineração, pois para iniciar a extração de carvão mineral, a mineradora Vale S/A removeu e reassentou famílias no distrito de Moatize.

Acredito que quando defini o tema da pesquisa em torno da mineradora e dos reassentamentos foi porque esse tema me permitiria transitar por questões que me instigavam a estudar: um processo colonial recente, um país que atravessou guerras e que durante a corrida imperial entre EUA e União Soviética, Moçambique esteve no lado socialista. Havia o desejo de estudar as particularidades de Moçambique nesses contextos e me aproximar dos estudos africanos e das especificidades do país. Além disso, havia a intenção de pensar nas relações entre Brasil e Moçambique pela forma e qualidade de acumulação no processo de modernização que passa pela mineração e, conforme a pesquisa revelou, pela financeirização e coloca esses dois países em relação.

Com o orientador prof $^{\circ}$ Carlos de Almeida Toledo, desde a minha graduação, voltamo-nos a analisar tais questões a partir da formação do Estado moçambicano com a territorialização do capital pela imposição das categorias capitalistas. Além disso, como as transformações do imperialismo incidem no país africano, buscando levantar as particularidades de como o processo ocorre. Ainda juntos, mas nos grupos do Labur que participei nesse período de mestrado, estudamos principalmente textos de Robert Kurz e 
Roswitha Scholz e então a crítica à sociedade produtora de mercadorias, sua crise imanente e o valor-dissociação.

A pesquisa em campo para essa pesquisa em si ocorreu no primeiro semestre de 2017 e foi realizada entre a Província de Tete e a Província de Maputo, com atividades divididas entre entrevistas, revisão bibliográfica e participação em eventos em torno da temática. A pesquisa propriamente nos reassentamentos no distrito de Moatize foi realizada em junho de 2014 (1 semana - durante o intercâmbio), julho de 2017 (1 mês) e setembro/ outubro de 2017 (2 semanas). Neles foi possível conversar com os moradores, acompanhar suas atividades diárias na tentativa de compreender as práticas que garantem a reprodução daquelas pessoas no contexto atual. Foi momento também de acessar as narrativas de quem guarda na memória parte do processo de mobilização para o trabalho e, pela oralidade, nos permitiram acessar elementos de como se deu a formação e reprodução das relações capitalistas no distrito, a partir da interpretação desses interlocutores. São esses mesmos interlocutores que compartilharam o momento atual de crise em que são supérfluos ao trabalho.

Inicialmente os conflitos dos reassentamentos foram apresentados pelos meus interlocutores de forma simplificada com reivindicações imediatas organizadas por importantes interlocutores durante a pesquisa de campo em Moatize: as lideranças de associações que também são moradores de dois reassentamentos por causa da mineração. São pessoas que se organizaram e se colocam como porta vozes da então população do distrito de Moatize, denunciando os conflitos causados após o processo de reassentamento com o início da atividade de exploração de carvão mineral pela empresa Vale S/A ${ }^{1}$ e apresentam insatisfações em relação às compensações definidas entre governo e empresa.

São situações expostas e reivindicações que aparecem como uma repetição já um tanto cansada por parte dessas pessoas e, durante as entrevistas realizadas, essas situações apareceram como respostas automáticas às questões variadas que lhes são feitas. Respostas automáticas e fechadas que se baseavam em situações problemáticas atuais e falas que comparavam o antes e o depois dos reassentamentos, no entanto, muitas das vezes desconectadas de uma totalidade e, nesse caso, o tom da conversa ora aparece saudoso em relação aos bairros Chipanga e Mithethe onde viviam anteriormente, como se

\footnotetext{
${ }^{1}$ Em documentos e pesquisas constam como Companhia Vale do Rio Doce ou Rio Doce Moçambique (pelo nome da empresa anterior à 2007), Projeto Moatize ou ainda Vale Moçambique. Trata-se de uma subsidiária do grupo Vale S/A.
} 
não houvesse contradições naquele período. Ora frustrado com a ideia de progresso que não se realizou.

Temos em conta que se a análise fosse restrita a essas narrativas organizadas pelos líderes das associações, sem as particularidades das famílias e dos indivíduos, tal perspectiva do problema poderia levar a uma interpretação como se houvesse uma homogeneização das relações nessas comunidades e como se fosse possível compreender tais relações, ou ainda, os conflitos que são expostos, a partir exclusivamente do tempo presente, com um recorte temporal que se restringe ao período em que a mineradora Vale S/A está em Moçambique. Não que essas falas/ denúncias não digam respeito ao que acontece nos reassentamentos e sejam sérias, mas consideramos uma insuficiência para a análise que aqui temos a pretensão de realizar em torno da sociedade produtora de mercadorias.

Nesse sentido, um desafio durante a pesquisa de campo esteve em levantar elementos nas entrevistas de modo que aparecessem as particularidades das famílias ou mesmo individuais, a partir de suas trajetórias que nos dessem base para compreender o processo de modernização que se desenrola e não ficarmos numa análise que aponta no sentido de conservação do que era. O movimento durante as entrevistas era de, ao ser feita uma pergunta sobre algo do passado, a resposta retornava ao presente com a descrição da catástrofe e em respostas que se tornavam muito semelhantes vindas de pessoas e contextos diferentes para expressar o descontentamento e a situação de humilhação em que vivem atualmente, por sentirem-se enganadas, por passarem extremas necessidades para sobrevivência sem a possibilidade de supri-las.

À medida em que a pesquisa avançou, a violência do processo de modernização e de imposição da forma de reprodução capitalista foi tornando-se mais nítida para mim. E organizei a apresentação da seguinte forma:

No primeiro capítulo tomamos como fio condutor as entrevistas com os moradores mais velhos dos reassentamentos e a revisão bibliográfica, de modo a apresentar os elementos empiricamente significantes ${ }^{2}$ em torno da própria mineração, sobretudo o trabalho nessa atividade, de maneira que possamos estudar a formação dessa categoria e relações em torno do fetiche da mercadoria. A definição desses elementos foram possíveis, pois ao longo das idas aos reassentamentos e com o avançar das conversas, a

\footnotetext{
${ }^{2}$ A importância dos elementos empiricamente significantes - baseado na formulação de Hartshorne - foi abordada por TOLEDO \& BOECHAT (2012) por serem eles a perspectiva do pesquisador sobre a apresentação do objeto e aquilo que caracteriza a área estudada e a diferencia das outras.
} 
relação com a mineração foi se tornando mais evidente como algo marcado na vida dessas pessoas ao constatar que muitos dos moradores mais velhos que vivem nessas comunidades trabalharam para a Companhia Carbonífera no período colonial e/ou na Empresa Estatal Carbonífera de Moçambique (CARBOMOC) no período socialista, após a nacionalização da Companhia. São empresas que já exploravam carvão mineral em Moatize. Então por esse caminho foi possível perceber o histórico de deslocamentos, pelo histórico de mobilização para o trabalho (GAUDEMAR, 1977) por essas mesmas pessoas e a coerção gradual à sociedade produtora de mercadorias. Nesse aspecto, a pesquisa em campo se consolidou por essa perspectiva e coloca os reassentamentos como parte de um processo, não o seu fim.

A narrativa tanto dos moradores membros das associações comunitárias (que entendemos como movimentos sociais), quanto desses moradores mais velhos e exmineiros, ou seja, diferentes gerações, levanta uma reflexão: atualmente eles não são considerados pela empresa, atualmente não há trabalho, mas antes havia trabalho.

Essas personificações (membros das associações e ex-trabalhadores mineiros) não constituem uma homogeneização de quem vive nos reassentamentos 25 de setembro e no Cateme, mas foram meus principais interlocutores. Os primeiros por serem os mediadores entre pesquisadores e comunidade enquanto que os segundos por serem ex trabalhadores e que guardam memória do processo de mobilização para o trabalho na mineração. Além disso, tornaram-se os principais interlocutores por falarem português e não apenas a língua local, onde predomina o nyungwe. Dados do Instituto Nacional de Estatística apontam que $66 \%$ da população de Moatize com 5 anos ou mais de idade não sabem português. Dos que conhecem, a maioria são homens dada a maior inserção na vida social, escolar e mercado de trabalho (MAE, 2005: 16). Assim, ter acesso a esses interlocutores facilitou a comunicação por não exigir a mediação de um tradutor, ainda que em algumas conversas tenha sido necessário e essa própria condição expõe uma limitação da pesquisa, pois essa é também a língua oficial do Estado e de pouca adesão pelas pessoas. Para exemplificar o estranhamento com a língua portuguesa no lado de lá e a naturalização no lado de cá, um dos interlocutores muito bem me questionou: Sua língua materna é a língua do colonizador!?

Ainda nesse primeiro capítulo, com os relatos desses moradores mais velhos, somados à revisão bibliográfica do período e do período que o precede, temos a intenção de conduzir a dissertação numa apresentação do processo de expropriação ao aprofundarmos a compreensão da formação do trabalho na área em que atualmente está o 
distrito de Moatize, onde está a mineradora Vale, numa região de mineração, no desejo de olhar os coloridos diferentes que a história da expropriação da base fundiária do produtor rural (MARX) assume em Moçambique pela territorialização do capital (HEIDEMANN et al, 2014) com o Estado colonial português, ou seja, antes mesmo de ser Moçambique.

Trata-se do processo de mobilização para o trabalho que passou tanto pela obrigação dos pagamentos de tributos, quanto da proibição do que era entendido como vadiagem e assim pessoas foram explicitamente forçadas ao trabalho. Essa expropriação ocorre em processo, pois à medida em que o maior tempo necessário para o pagamento de impostos ou o cumprimento do trabalho forçado, levou à diminuição da produção nas machambas ${ }^{3}$. Compreendemos, portanto, esse processo como de expropriação, mesmo os agricultores mantendo o acesso à terra.

No segundo capítulo partimos do processo de Libertação de Moçambique que pode ser entendido como de transformação na forma de reprodução ao ser uma tentativa de modernização na qual o Estado Nacional aparece em primeiro plano, um Estado centralizador, militarizado, planejador, gestor do processo de produção de mercadorias. Entre as ações durante esse governo socialista esteve a estatização da terra pela Lei de Terras, numa política que pode ser pensada como de ruptura com o processo de latifúndio ou mesmo de monocultura que as Companhias formavam e também da normatização do acesso à terra.

Além de nacionalizar, a Lei de Terras é compreendida por alguns autores, como por exemplo Negrão, como inovadora ao incluir os sistemas costumeiros na determinação do direito de uso da terra. No entanto, qual é a garantia de acesso à terra que a nova Lei de terras proporciona às famílias camponesas, principalmente após o Estado realizar a abertura econômica para o capital estrangeiro com a exploração mineira por multinacionais?

A mineradora Vale S/A foi a primeira grande mineradora no novo momento de exploração, no início dos anos 2000 e então voltamos ao trabalho de campo para perceber nas particularidades o processo que envolve as concessões com as relações de produção locais e como as transformações nas relações de produção em decorrência da dificuldade de acesso à terra fértil recai principalmente sobre as mulheres.

\footnotetext{
${ }^{3}$ Área de cultivo agrícola familiar, roça.
} 
No terceiro capítulo apresentamos como as forças produtivas utilizadas na exploração do carvão em Moçambique tanto no período colonial quanto socialista tornouse obsoleta a partir do novo padrão de produtividade que o desenvolvimento das forças produtivas possibilitou. Ao o país africano não ter estrutura que acompanhasse tal processo de modernização, podemos dizer que em Moçambique não havia mineradoras que tivessem a tecnologia nas mesmas condições que as grandes mineradoras. Assim, tornou-se inviável explorar os recursos e competir nesse mercado, por isso a abertura para multinacionais tornou-se inevitável para que o Estado moçambicano tenha meios de continuar a exploração de carvão mineral, meio de obter dinheiro e manter suas relações no mundo da mercadoria.

As máquinas mais modernas do setor passaram a fazer parte da produção de carvão em Moçambique e esse desenvolvimento das forças produtivas possibilitou de forma irreversível a aceleração da produção da mercadoria e o ciclo da reprodução de capital. Diferentemente dos períodos anteriores que a exploração acontecia em galerias subterrâneas pelas mãos dos mineiros, nesse momento a exploração passa a ser com máquinas e a céu aberto, o que faz avançar a área de exploração velozmente, excluindo dessas áreas de concessão as pessoas que antes viviam e outras formas de reprodução, práticas sociais e simbólicas.

Para analisarmos esse momento, temos como base referências de estudos realizados por pesquisadores moçambicanos vinculados a instituições localizadas na capital Maputo, entre elas o Instituto de Estudos Sociais e Econômicos (IESE), o Observatório do Meio Rural (OMR) e o Centro de Integridade Pública (CIP).

O IESE se define como "uma organização de pesquisa fundada em 2007 com questões em torno do desenvolvimento econômico, social e político". Entre seus financiadores estão a República da Irlanda, da Finlândia, Cooperação Suíça e a Oxfam Ibis - Moçambique (que tem sede na Dinamarca). A OMR é uma organização cujas pesquisas tem como temática o "desenvolvimento (sustentável) rural" e formada por pesquisadores que se colocam na intenção de "contribuir para a elaboração de políticas agrárias". Essa organização tem como parceiros a Fundação Masc e Agir (ambos de Moçambique), a Confederação Suíça, Embaixada da Suécia, Dinamarca e a Universidade Politécnica. Ou seja, quem financia as pesquisas são as mesmas agências na maioria das vezes. Por fim o CIP foi criado em 2005 e coloca-se como apartidária, sem fins lucrativos, com autonomia administrativa e com uma "finalidade anticorrupção, pela integridade e para contribuir com um governo democrático no país". Ainda que se autodeclarem com 
autonomia financeira, entre os patrocinadores do Centro estão muitas das mesmas instituições que financiam os centros de pesquisa citados anteriormente: Confederação da Suíça, Oxfam, UKaid, Embaixada da Noruega, Reino dos países baixos, Embaixada da Suécia, Embaixada do Canadá, Open Society Initiative for Southern Africa (OSISA) e Agir.

Diferentemente do que iremos apresentar no segundo capítulo, em que as pesquisas realizadas pelo Centro de Estudos Africanos (CEA) da UEM tinham a finalidade de dar base às políticas estatais, nesse novo momento de reprodução que apresentaremos no terceiro capítulo as pesquisas no país africano parecem ter sido expandidas para além da Universidade e passaram a ser feitas em organizações formadas por graduados, mestres e doutores do país que são de diferentes especialidades acadêmicas e são financiadas por instituições internacionais. As organizações citadas como referência para essa parte da dissertação tem um número expressivo de publicações na forma de artigos e promovem frequentes eventos na capital moçambicana para debater e apresentar as pesquisas que, em grande parte, apresentam dados sobre o que definem como megaprojetos. Trata-se da expansão da produção de commodities tanto na área da mineração quanto do agronegócio para Moçambique.

A Vale S/A foi a primeira mineradora multinacional a assinar contrato nesse novo momento de produção do carvão no país, e, nesse sentido, apresentaremos nesse capítulo a expansão das atividades da mineradora como política que envolve o Estado de Moçambique e também do Brasil. Por isso baseamo-nos também em publicações de pesquisadores brasileiros.

Por fim, no quarto capítulo apresentamos como as mineradoras multinacionais transformaram as relações de trabalho ao introduzirem em Moçambique as máquinas mais modernas da mineração e, assim, a modernização dos meios de produção coloca como critério a condição de ser um trabalhador especializado e estes são principalmente migrantes. Nesse capítulo apresentamos as relações de especialização do trabalho e como incide sobre as pessoas que vivem no distrito de Moatize, sobretudo a partir dos moradores dos reassentamentos Cateme e 25 de setembro.

É momento em que os moradores mais velhos dos reassentamentos voltam-se para o presente e, como se descolassem da violência extra econômica que acompanhou parte do processo de imposição do trabalho, reivindicam por trabalho ao verem-se diante das dificuldades de reprodução atual, pois diferentemente, nesse novo momento em que a extração se dá a céu aberto, os moradores de Moatize tem pouca participação no quadro 
de funcionários dessas multinacionais e esses mesmos antigos mineiros questionam-se como os jovens poderão um dia vir a ser reformados ${ }^{4}$ se atualmente não trabalham e como viverão quando forem mais velhos. Somado a isso, não há machambas para a produção de alimentos. Apresentaremos, assim, o que o trabalho de campo revelou em relação aos moradores mais jovens de modo a perceber suas estratégias de reprodução em meio à crise do trabalho que se aprofunda, nesse momento em que são tidos como supérfluos ao sistema e também sem machambas.

Ressalto que, para preservar a identidade desses meus interlocutores, os nomes que apresento nessa dissertação são nomes fictícios, uma tarefa conflituosa para mim, mas que compreendo como necessária.

Ressalto ainda que essa pesquisa foi realizada entre o golpe de 2016 no Brasil e as eleições presidenciais de 2018 em que, entre as propostas, esteve a criminalização de movimentos sociais e eliminação de ativistas brasileiros. $O$ que repudiamos veementemente.

\footnotetext{
${ }^{4}$ Aposentados
} 


\section{Capítulo 1: Entre fetiches e autoridades: formação do trabalho}

\subsection{Os reassentamentos da Vale S/A: Cateme e 25 de Setembro:}

"Há problemas, não há trabalho"

Casas com fissuras. Trincas. 7, 8 pessoas tendo um quarto e uma sala. Degradação das famílias. Difícil dormir. Reassentamento teve erros. Pensavam que iam trabalhar. Eram oleiros. Agora vai fazer o que? Fome. Desnutrida. Sem dinheiro. Quem não quer trabalhar? O dinheiro é para acabar com a vida da pessoa. Ficam mais pobres. Tradições precisavam ser respeitadas. Polícia muito forte. Aqui respira-se o não ar puro. Já não podemos estender farinha fora. A roupa, se lava e deixa: sai suja. Vamos ter muitas doenças. Essa vida não favorece. As casas tremem com as explosões. Casas cheias de racha. Aí não temos como viver mesmo. Isso foi uma confusão. Separou famílias. Até hoje é triste. Casas péssimas. Uma coisa muito complicada. A água não é suficiente. A água é salgada. Carvão é perigo. Água salgada é perigo. A vida está difícil. Estamos a sofrer. Sou jovem. Muitos jovens estão a sofrer. É sentimento. A vida está cara. Eles nos enganaram. Fabricava tijolo. Estava perto da cidade. Onde vou trabalhar? Estou morto assim. Está sentada em cima das mãos, sem ocupação. Eu não tenho a $12^{a}$ classe. Tudo é comprar. Água que estamos a beber: urina sangue. Casas que não tem recuperação. Está frágil. Não tem transporte. Há pessoas que estão a usufruir. Casas cheias de problemas. Não temos espaço para agricultura. A mineração está no quintal das pessoas. Desemprego. Não temos boa vida. Temos uma vida negativa. Poluição. Tosse. Tuberculose. Água poluída. Resíduos de carvão. Comida com carvão: comer. Estamos mal. Lá tinha lenha. Perdemos pessoa. Estão a comer com a VALE. O cabrito come onde está amarrado. Não tem escola. É triste. Não há dinheiro. Não estamos de boa vida. Mulher está a sofrer. Machamba: não temos. As casas não tem alicerce. Problemas que estão a nos trazer desgraça. Estou como uma mulher. Não temos ocupação. Sentada a depender do marido. A mulher não ficava tanto aflita. Aqui não tem rio. Aqui pagamos essa energia. Pessoa sofre. A promessa não foi cumprida. Não estamos satisfeitos. Não tem dinheiro para chapa. Nos tiraram de lá, agora estão as máquinas. A tecnologia está bem avançada, mas antes tudo tínhamos. Muitos jovens estão a perder a vida. É uma vida muito triste. As chapas das casas parecem pintadas de preto. Estamos contaminados. Muita doença é fácil de atingir. A terra não é boa para produção. Vedaram: não tem como ir visitar. Deixa a mulher na desgraça. Contrato acaba. Prometia o melhoramento 
da vida futura. Epidemia. Não tem mercado. Demoliu as casas. In-ti-mi-da-ção. Os brancos vieram. Condições péssimas. A pior coisa que foi feita. Zonas pedregosas. Não estou a ver o que estou a fazer aqui. É grande sofrimento. Como vou fazer? Quero comer, epah: tem outros também. Esses filhos vão morrer. Eu tenho essa preocupação. Foi uma farsa. Ninguém explica. O roubo sai da pobreza. Tem problema aí. Há falhas. Assunto crítico. Não tem água aí. Aqui tinha dono daqui. Arrancou as machambas. Serviço não há. Deveriam nos considerar. Nos tiraram, acabou. Grande sentimento... grande mesmo. Somos pessoas! Taj a ver?

Assim é chegar nos reassentamentos e assim o problema se manifesta: pelo sofrimento, situações e sentimentos que são expressos repetidamente em pesquisa de campo, vindos de pessoas que expõem como tem sido o dia a dia numa área de mineração, há quase 10 anos. Poderia ser em Bento Rodrigues, Minas Gerais, ou ainda Parauapebas no Pará. Poderia ser dessas tantas áreas que são concedidas à mineradoras para a agressiva exploração que devasta o lugar tanto em aspectos físicos quanto sociais e simbólicos, gerando assim conflitos com moradores locais ${ }^{5}$. Mas esses fragmentos que aqui apresentamos são vozes vindas de pessoas que vivem nos reassentamentos 25 de setembro e Cateme, do distrito de Moatize, na Província de Tete, centro de Moçambique, para onde foram forçadamente reassentadas pessoas que viviam numa área que o Estado moçambicano concedeu à mineradora Vale S/A. O Estado moçambicano concedeu a área para a multinacional Vale S/A em 2004 primeiramente para pesquisa, em seguida foi feito o Estudo de Impacto Ambiental em 2006 e por fim o contrato firmado em 2007 para extração de carvão mineral, atividade que se iniciou em 2011. Com o contrato a empresa passou a ter direito exclusivo de minerar, processar, transportar, armazenar e comercializar minério de carvão, por um período inicial de 25 anos, podendo ser renovado posteriormente (REPÚBLICA DE MOÇAMBIQUE, 2007). Essa área foi na altura considerada a maior área carbonífera não explorada do mundo.

Esse fragmento inicial é formado por frases simples e cheias de significados ditas em português por pessoas que não tem o português como língua materna, ou seja, a primeira língua não é a do colonizador. Pessoas que a mim pareciam assumir uma postura de denunciar as condições que foram postas a viver, conforme melhor iremos apresentar

\footnotetext{
${ }^{5}$ No Brasil, são muitos movimentos sociais que denunciam a violência em torno da mineração: Movimento Atingidos por Barragens, Atingidos pela Vale, Comitê Nacional em Defesa dos territórios Frente à Mineração, dentre outros. Entre as publicações que conhecemos e que expõem esses impactos recomendamos: O Dossiê dos Impactos e Violações da Vale no Mundo de 2010, o Relatório de Insustentabilidade Vale 2015, ambos do movimento Atingidos pela Vale.
} 
ao longo da dissertação. Essas situações conflituosas que eles atravessam atualmente foram muitas das vezes apresentadas na intenção de que sejam levadas a instâncias maiores, a quem acreditam que tem poder de retirá-los dessa situação. E é dessa forma que o conflito foi apresentado: de modo urgente, pelo que é visível, sentido no momento e a partir disso selecionei frases como uma síntese de um lamento que tem o peso das angústias vividas e o desejo, mas a incapacidade prática de transformá-las. Conforme repetidamente foi colocado por eles, são sentimentos que estão nesses conflitos. Ainda que não tenha classificado exatamente quais sentimentos, um dos interlocutores em pesquisa de campo desculpou-se por tê-los transferido a mim pelo relato que fez. Ao leitor, repasso a mensagem.

O reassentamento 25 de setembro está localizado na vila de Moatize e para chegar nele era possível ir de transporte coletivo, popularmente chamado de chapa, saindo de Tete até a vila de Moatize e de lá era possível ir a pé ou moto taxi. Já para ir ao reassentamento Cateme era preciso ir com um segundo chapa da vila até lá. Esse segundo percurso, de aproximadamente $40 \mathrm{~km}$, levava em torno de $1 \mathrm{~h} 30$ considerando as paragens para descida/ subida de passageiros ao longo do trajeto, além das paradas feitas por policiais que buscavam qualquer irregularidade com que pudessem trocar por dinheiro. Nesses percursos era possível perceber as dinâmicas do lugar, as aglomerações, trabalhos informais e como esses fluxos iam diminuindo à medida que nos aproximávamos de Cateme e a paisagem passava a ser predominantemente a savana rasgada pela avenida com o lado direito da estrada isolado pela cerca da mineradora Vale S/A, daquela área a ser explorada futuramente.

Tete é conhecida como a Província mais quente de Moçambique, possível de chegar aos $45^{\circ} \mathrm{C}$. Por isso as atividades do dia começam muito cedo para que seja possível estar no lugar de destino antes do sol aquecer e assim as atividades encerram cedo também. A escolha da atividade e de qual reassentamento ir no dia de pesquisa muitas das vezes dependeu da disponibilidade dos interlocutores que mediaram a relação: os membros de associações da sociedade civil. Essa dependência de um membro da associação estava por ser a maneira que me sentia mais segura e respeitosa no processo de aproximação: eles mediavam na conduta dos códigos locais, na dinâmica local e ainda faziam a mediação pela questão da língua.

Essas pessoas que fizeram a mediação também são residentes do distrito de Moatize e são membros de associações já formadas ou em processo de formação e de definição de pautas. Eles reuniram-se por causa dos problemas que as comunidades tem 
atravessado em consequência da atividade mineira. Meus principais mediadores são vinculados à associação de Comunidades Afetadas Pela Mineração e Indústria extrativa (CAPEMI) e à Rede de Associações de Moatize para a Boa Governação (RAMBOG). Também conversei com membros da Associação de Apoio e Assistência Jurídica às Comunidades (AAAJC) e na União Provincial dos Camponeses de Tete (UPCT). A UPCT é a única entre essas que é vinculada ao Estado, pois é parte da União Nacional dos Camponeses (UNAC). A UPCT apresentou-se como uma organização que tem como finalidade prestar serviços aos camponeses quando eles buscam o apoio ou esclarecimentos de dúvidas como, por exemplo, sobre legislação, conforme nos relatou a presidente da União. Percebemos dessa organização assim, uma postura passiva por ter uma finalidade que está para o esclarecimento das leis para quem busca informação daquilo que é tido como direito dos camponeses, enquanto as demais organizações acreditamos que assumem uma posição mais ativa por serem formadas por pessoas que estão imersas nas relações as quais problematizam e se organizam para buscar interlocutores para quem possam levar os problemas das comunidades e da mesma maneira com reivindicação dos direitos e cumprimento da lei ou ainda o aperfeiçoamento dela. Assim um ponto de encontro entre as associações: a crença jurídica, na justiça e consequentemente no Estado como responsável pela gestão dos problemas.

São pessoas articuladas e que atualmente fazem essa mediação entre pesquisadores que dirigem-se ao distrito. Esses pesquisadores por sua vez são vinculados à organizações não governamentais, universidades, embaixadas ou mesmo empresas privadas que financiam a mobilização deles para o distrito. Os temas dos estudos dividem-se por diferentes especificidades da ciência, mas geralmente em torno da mineração, o que mostra instituições dispostas a pagar por pesquisas que envolvem o tema, ainda que com diferentes objetivos. Ao longo dessa pesquisa como um todo, deparamo-nos com diferentes trabalhos que tratam sobre a mineradora Vale S/A em Moçambique e de diferentes áreas do conhecimento científico, seja da área ambiental, de saúde, da antropologia, o que demonstra a abrangência dos impactos e de diferentes ordens. Pesquisas realizadas por pesquisadores brasileiros, moçambicanos ou ainda de outras nacionalidades.

Dessa forma, os membros das associações auxiliam nas pesquisas ao colocaremse como mediadores entre pesquisadores e moradores e conhecerem o processo de reassentamentos. Por morarem neles ou mesmo em outros bairros do distrito, viverem da mesma maneira os constrangimentos e as incertezas que a mineração os coloca, pois são 
também pessoas que guardam histórias individuais de mobilidade para o trabalho. Nessa complexidade de relações, um dos membros de uma associação disse dar prioridade para trabalhar com grandes organizações, como a Justiça Ambiental, por ser uma organização que abriu portas e levou os problemas deles para instâncias maiores e possibilitou que eles pudessem participar de conferências internacionais para denunciar as violações de direitos em Moatize e por isso interessa organizações que dão maior visibilidade aos reassentamentos. E nesse ponto, concordamos que de fato dão visibilidade, pois até mesmo essa pesquisa nasceu de um momento em que a questão dos reassentamentos foi divulgada em jornais impressos no país africano, pela televisão e era assunto comentado entre moradores de Maputo.

Comparando os períodos de pesquisa em campo, é possível dizer que em 2017 havia mais associações ao longo do país se comparado a 2014. Esse aumento das associações foi relatado pelo pesquisador moçambicano Feijó (2016) que argumenta tal aumento pela expansão dos megaprojetos (produção de commodities) e consequentemente dos conflitos que eles causam, então cria-se uma demanda em termos de objetivos e necessidade de atuação. Além disso, houve aumento nas fontes de financiamentos para tais pesquisas (FEIJÓ, 2016: 11).

Assim, as associações expõem de forma urgente e imediata os problemas cotidianos e o que consideram como injusto no processo que envolve a mineração e os reassentamentos e tentam legitimar suas reivindicações com base na legislação moçambicana. Um procedimento que não se restringe a tais movimentos sociais, pois é também argumento de pesquisadores que debruçam-se sobre o tema e colocam-se no sentido de aperfeiçoar a lei.

Nesse âmbito, as pesquisadoras moçambicanas Osório \& Silva (2017: 7) realizaram um estudo ${ }^{6}$ em colaboração com essas organizações visando formar activistas que advoguem a protecção e defesa dos direitos humanos, particularmente no que respeita às mulheres que vivem na área carbonífera. Essa pesquisa destaca alguns pontos no processo de reassentamento: falhas na aplicação das leis e pouca participação das comunidades nas decisões; a legislação não considera as diferenciações na divisão do trabalho por gênero agravando situações de violência doméstica; e por fim o que elas chamam de depressão nas comunidades e o sentimento de exclusão. Sendo assim, os problemas são lidos pela forma visível, física e analisados a partir dos reassentamentos

\footnotetext{
${ }^{6}$ Pesquisa financiada pela União Europeia e realizada pela organização não governamental regional Women and Law in Southern Africa Research and Education Trust (WLSA).
} 
em si, cujos problemas seriam passíveis de correção jurídica e consequentemente o Estado aparece como o regulador da situação.

Um importante interlocutor durante a pesquisa em campo, aqui iremos chamá-lo de Sr. Ivan, é membro de uma das associações e ex-trabalhador na empresa "Diagonal transformação de territórios"7 . Essa é a empresa que realizou o plano e execução dos reassentamentos da Vale S/A em Moatize. Trata-se de uma empresa de consultoria que tem projetos em 21 países, entre a América Latina, África e sudeste asiático.

Enquanto trabalhou na Diagonal, Ivan atuou diretamente nas comunidades que foram reassentadas. Ele tinha a função de informar àquelas pessoas, em nyungue, sobre o reassentamento e fazia a mediação entre as famílias e a empresa. Esse momento foi narrado por uma reassentada como momento que: Parecia brincadeira quando diziam que iriamos sair para ser reassentados. Será que é verdade ou não?

Foi verdade. E 1365 famílias foram removidas principalmente dos bairros Chipanga e Mithethe. Isso corresponde a mais de 5000 pessoas que foram forçadamente removidas de seus locais de moradia para serem reassentadas entre 2009 e 2010 (MOSCA \& SELEMANE, 2011: 20). Atualmente, passados quase 10 anos, o número de pessoas nos reassentamentos aumentou. As crianças cresceram, casaram-se, tem filhos. As mulheres foram viver na terra da família do marido. Homens vivem na terra dos pais, com esposa e filhos. Além de outros fatores que levaram pessoas de outras áreas a se juntarem à área do reassentamento.

Nessas circunstâncias, compreendemos que houve um ciclo de pesquisadores que transitam pelo distrito, primeiramente pesquisadores vinculados às licenças para pesquisa de minérios. Após a concessão, pesquisadores vinculados ao processo de estudo de impacto ambiental, compensações e reassentamentos, sendo assim pesquisadores ligados às mineradoras. Num segundo momento viriam pesquisas vinculadas a Universidades e/ou Organizações Não Governamentais após o início das atividades de extração para pensarem nas consequências do processo ou articularem estratégias e projetos que compreendemos como de redução de danos. De qualquer forma, a sensação é de que os moradores estão constantemente sob análise, tem respostas automáticas para diferentes perguntas, ao mesmo tempo mostram-se apreensivos, sob incertezas, insatisfeitos e cansados de estarem nessa posição de quem é estudado. Nesse imbróglio, seria correto

\footnotetext{
${ }^{7}$ O fundador da empresa é Álvaro Oscar Ferraz Jucá, irmão do senador brasileiro Romero Jucá.
} 
pensar que o trabalho nas associações se autonomizou como resultado do próprio processo de modernização que coloca a necessidade do dinheiro?

Meu interlocutor Ivan era, a princípio, contratado pela empresa Vale S/A. Após um período, os trabalhos da empresa foram divididos por áreas, ou seja, iniciou a terceirização de setores. Foi quando ele foi trabalhar na empresa Diagonal onde permaneceu por 5 anos. Para ele algumas relações na empresa foram de estranhamento: havia problemas de ter muitos chefes, uma comunicação ruim, conflitos e podia haver pessoas que trabalhavam juntas todos os dias sem se comunicar por terem desavenças. Tais comportamentos entre os funcionários, que qualificou como competitivos, eram para ele surpreendentes e assim configurou-se um ambiente de trabalho que não considerava bom. Além disso, $\mathrm{O}$ sr. Ivan relatou que tinha que acordar as $5 \mathrm{~h}$ para pegar o "ônibus ${ }^{8}$ como vcs dizem" e só regressava à casa às $20 \mathrm{~h}$. Por não ter uma circulação de transporte público que faça esse itinerário, quando perdia o ônibus ele tinha de ir a pé, mesmo para chegar tarde, caso contrário teria problemas. As relações hierárquicas que refletiam em diferentes regras eram para ele injustas e o trabalho deles [chefes] nunca estava errado ou mal feito, apenas o trabalho dos outros. No entanto, diz que o motivo central que levou à sua saída da empresa foi ao perceber que as famílias que foram reassentadas estavam insatisfeitas: as casas eram pequenas ( 2 cômodos) para famílias grandes, havia a impossibilidade de machambas que era a principal atividade realizada pelas mulheres, a interrupção das olarias que era uma importante atividade para os homens, a distância da cidade, dentre outros aspectos que ainda iremos retomar. O sr. Ivan percebeu que os outros funcionários da Diagonal eram migrantes, seja do Brasil ou de outras partes de Moçambique, enquanto ele não. Assim, ele ficaria mal visto pelos seus conterrâneos. Exemplificou que outros dois colegas de Moatize não perceberam essa relação, não saíram da Diagonal e atualmente não podem ir aos reassentamentos. Disse, então, que é por perceber a injustiça que foi feita que tem trabalhado com organizações que dão apoio às pessoas que foram reassentadas.

Outro elemento que possibilitou que saísse da empresa, foi por ter concluído o curso superior: como a Vale paga em dólar, houve período que ganhava bem mesmo. Sendo assim, concluiu o curso em gestão ambiental e formou uma associação que veio a ser seu novo trabalho. Por isso gosta de conhecer as pesquisas que são feitas, pois diz que assim consegue ter dimensão do que vai acontecer no distrito de Moatize. Dentre as ações

\footnotetext{
${ }^{8}$ Em Moçambique o transporte coletivo regular é chamado de machibombo.
} 
já realizadas pela associação que faz parte está a organização do pedido de indenização que ocorreu após as pessoas já estarem reassentadas.

Refletindo sobre sua experiência pessoal, sr. Ivan lembra: Não vale a pena envelhecer trabalhando tantas horas como fazia lá. E compartilha que os pais dele não compreenderam o porquê dele ter saído, pois antes comiam dois pães agora comem um. Ele considera melhor comer apenas um pão, mas viver em paz e manifesta: A vida está aqui para termos prazer também, pah! Não pode consistir em apenas trabalho. Uma conclusão a partir de sua experiência individual e de quem tem minimamente a possibilidade de reprodução social e acessar as coisas que são mediadas pelo dinheiro. Mas quando pensado em coletivo, e nas pessoas que ele representa, reivindica por trabalho para que possam da mesma forma ter uma maneira de se reproduzir.

Esse princípio aparece de forma bastante ostensiva para os moradores dos reassentamentos e a reivindicação por trabalho é colocada pelos membros das associações e alguns outros moradores dos reassentamentos como um direito, sobretudo por estarem na condição atual por causa de um processo que é liderado por uma mineradora com as dimensões da Vale S/A e a imensa área que explora, a quantidade de carvão que produz, os valores envolvidos no empreendimento. Essa constatação faz com que o emprego da energia humana pareça necessário para que a produção aconteça e, nesse sentido, o trabalhador local é posto por eles mesmo como o ideal, pois são eles quem conhecem o lugar e por serem eles que convivem com os constrangimentos causados pela mineração, deveriam ser eles também que deveriam se beneficiar do dinheiro na forma de salário. Uma premissa que se repete em movimentos sociais ligados à mineração não apenas de Moçambique, como também no próprio Brasil com relação às mineradoras que estão no país latino americano.

Em Moatize há moradores homens que trabalharam muitos anos na mineração, conhecem a área da exploração e dizem estar dispostos a trabalhar novamente na mineração. Eles tem a memória da exploração do carvão bastante abrangente e são capazes de narrar as mudanças nas relações de trabalho ao longo do tempo nessa mesma atividade econômica, atravessando políticas que a organizaram de maneira distinta, como se longos anos tivessem sido comprimidos e agora pudessem ser narrados por uma pessoa, uma geração que experienciou esses longos anos. Esse é um ser de fronteira como diz Mia Couto 9 . Muitos dos moradores dos reassentamentos ou seus antepassados trabalharam na

\footnotetext{
${ }^{9}$ Sobre sua experiência pessoal ele compartilha: "O meu país tem países diversos dentro, profundamente dividido entre universos culturais e sociais variados. Eu mesmo sou a prova desse cruzar de mundos e de
} 
Companhia Carbonífera sob o controle do Estado colonial português e/ou na Carbomoc, após a Libertação, durante o governo socialista.

Nas conversas com alguns desses ex-mineiros, o desemprego aparece sistematicamente como a causa dos problemas que atravessam, pois com salário teriam maneira de acessar as mercadorias de que precisam e aquilo que o processo de deslocamento lhes tirou. Contraditoriamente, ao longo das conversas em que retomamos o histórico da mineração e que chegamos no período colonial, meus interlocutores, sobretudo os mais velhos, apontaram que naquele tempo havia trabalho, ou seja, na Companhia Carbonífera.

Essa constatação pode levar ao espanto pela sua contradição, pois a maneira que esse elemento é colocado na conversa pode parecer como um elogio por parecer um fator positivo do período colonial. Esse é um lugar bastante sensível e lembremos que trata-se de um país que esteve em Luta Armada contra o regime colonial. No entanto, esse argumento se torna positivo apenas quando comparado com o momento atual. Por quê?

O cenário atual de ambos os reassentamentos é anunciado e compreendido como de escassez e que passa pela escassez de alimento e de água, ou seja, o mínimo para a sobrevivência, então ao trazerem essa lembrança de que antes havia trabalho torna-se relevante. Mas o que nos comunicam é que salário e alimento em troca do tempo e da energia que depositavam no trabalho durante o período da Companhia Carbonífera, era uma troca justa? Seria a falta de trabalho o principal fator para a escassez atual?

1.2. Relações de fetiche e o trabalho escravo na região do Vale do Zambeze

Para compreendermos as relações de trabalho no período colonial, fez-se necessário pensar na formação do Estado colonial português, seu processo de territorialização e assim como se deu a organização das relações para a produção capitalista. Fez-se necessário retomar o período que precede a chegada desses europeus àquela região para termos o esboço das relações pré-coloniais da área que atualmente conhecemos como Moçambique e onde um regime colonial desestruturou e impôs relações que, em processo, formaram a relação capital-trabalho.

tempos. Sou moçambicano, filho de portugueses, vivi o sistema colonial, combati pela independência, vivi mudanças radicais do socialismo ao capitalismo, da revolução à guerra civil. Nasci num tempo de charneira, entre um mundo que nascia e outro que morria. Entre uma pátria que nunca houve e outra que ainda está nascendo. Essa condição de um ser de fronteira marcou-me para sempre.” (COUTO, 2009: 123) 
No livro Trato dos Viventes: formação do Brasil no Atlântico Sul, ao analisar o comércio no Atlântico Sul, o historiador brasileiro Alencastro (2000) tem como argumento a dificuldade que Lisboa teve para dominar Moçambique e apresenta essa análise pela região do Vale do Zambeze, área do maior rio da África Austral ${ }^{10}$. Num mesmo argumento, Newitt, (1995: 124) diz que por mais que desde o século XVI houvesse portugueses na área que hoje reconhecemos como Moçambique, quando Vasco da Gama visitou a Ilha de Moçambique em 1498 e nela foi estabelecida uma feitoria portuguesa em 1502, muitas foram as tentativas de avançar para o interior do continente e chegar onde está Tete. No entanto, essas tentativas foram de fracasso.

Foi principalmente nas obras dos historiadores David Hedges (1999) e Malyn Newitt (1997) que encontramos elementos que nos permitem pensar as particularidades das relações no Vale do Zambeze que dificultaram essa relação de dominação naquela região e como os portugueses fizeram para explorar e lentamente impor a estrutura de produção capitalista. O trabalho de ambos autores é intitulado História de Moçambique, mas por mais que possam, com esse título, sugerir uma única história de Moçambique, ambos autores fazem suas ponderações sobre a complexidade daquele país, sem o desejo de que esses livros fossem a história oficial. Newitt (1997: 13) declarou que na pesquisa que realizou pretendia resumir a experiência vivida pelas sociedades que existiam dentro da área que em 1891 se tornou Moçambique e ele fez essa análise considerando processos de integração e desintegração. Além disso, ambas publicações tem a data bastante próxima, nos anos 1990. Newitt se posiciona ao dizer que escreveu num momento apropriado, pois foi logo após "a catástrofe que se abateu sobre o país", o que compreendemos que o autor se refere ao período que inclui a guerra civil travada no país e inclui o colapso do que foi o socialismo em Moçambique, sendo assim, essas publicações ocorrem no período da introdução oficial do país na "livre" economia de mercado, cujo momento do processo histórico da modernização e da sociedade do trabalho é baseado na economia da concorrência.

A partir dessas referências compreendemos que no século XVII, quando os portugueses chegaram àquela área do Alto do Zambeze, ou seja, na área em que está localizada a Província de Tete, conforme atualmente é denominada, já havia relações de

\footnotetext{
${ }^{10}$ A nascente do rio Zambeze está na atual Zâmbia (antiga Rodésia do Norte), país que está a noroeste da Província de Tete. O fluxo segue sentido leste e é um limite natural entre os países Zâmbia e Zimbábue (antiga Rodésia do Sul), atinge o atual Moçambique também demarcando limites das províncias Tete-Sofala e Zambézia-Sofala, até desaguar no Oceano Índico. O relevo escarpado forma as famosas Cataratas Victória possível de ser acessada pela cidade Livingstone, cujo nome é em homenagem ao explorador britânico, na altura em que a rainha era Victória.
} 
produção, comércio e de controle do território e por isso os portugueses não dominaram facilmente. Alencastro (2000) apontou que o acesso à terra no Vale do Zambeze era feito inicialmente em troca de tecidos, assim como mercadores árabes já faziam previamente, cuja relação iniciou no litoral do país ${ }^{11}$. Isso demonstra que o acesso à terra não era necessariamente uma relação monetária, mas para ter acesso e permanência havia a condição do pagamento desse tributo em produto. Tal tributo era pago ao imperador do Monomotapa (ALENCASTRO, 2000: 18). De um modo geral, a historiografia consultada (Alencastro, Hedges, Newitt, Serra) apresenta como Império Monomotapa e estava ao sul do rio Zambeze, ou seja, na margem direita (SERRA, 2000: 35) e abrange onde atualmente está a parte administrativa da cidade de Tete.

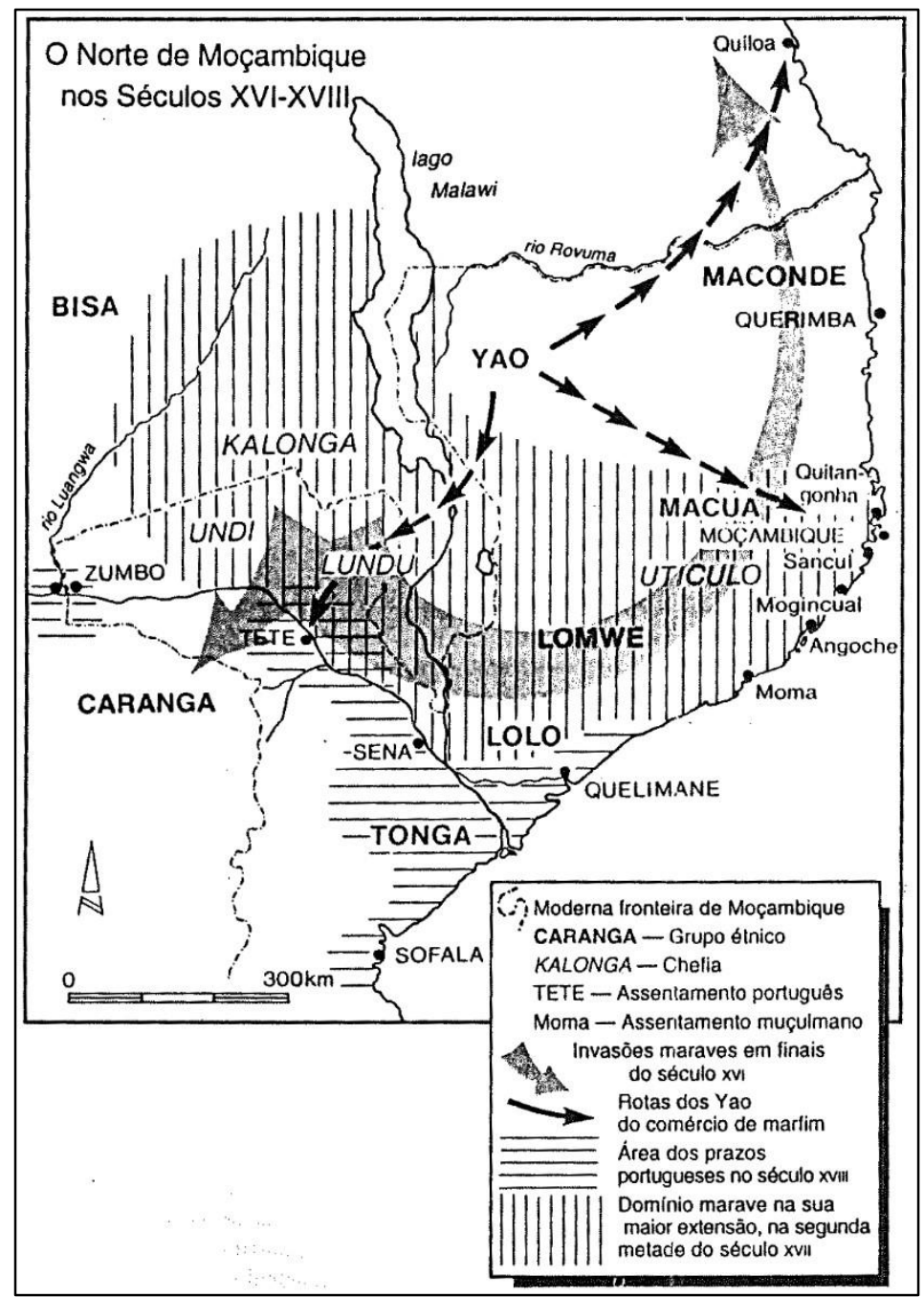

Figura 1:Grupos étnicos. Fonte: Newitt, 1997: 74

\footnotetext{
${ }^{11}$ As capulanas são tecidos que foram inicialmente comercializados por árabes na costa de Moçambique. Atualmente esses tecidos são conhecidos no Brasil, por exemplo, com a característica de serem tecidos africanos, cujas estampas são facilmente identificadas. Em Moçambique é apontado como um dos produtos que representa a identidade do país.
} 
A questão que fazemos é o que mobilizava o pagamento do tributo? O que coagia para que as pessoas realizassem essa transação que então os portugueses seguiram? Ou ainda, aquele que pagava o tributo, compreendia que estava pagando por qual motivo?

Ainda de acordo com os autores consultados, o império teria se formado após agricultores bantos serem subordinados a imigrantes da etnia hima (do Alto Nilo). Deles nascem os Carangas, que falavam shona (MAIA, 2015, 47; SERRA, 2000, 34). Newitt (1997: 83) apresenta que os Carangas teriam relações de controle formadas por várias monarquias cujo poder assentava no culto dos espíritos, no controle dos agricultores das aldeias e dos mercados vindos da costa.

Essa relação de poder nos parece distinguir da relação de poder formulada pelo geógrafo Raffestin (1993: 56), por exemplo. O geógrafo define o poder pela capacidade de transformar o meio natural e social pelo trabalho. Enquanto a relação de poder apresentada por Newitt nos parece que se constitui pelo sentido transcendental, metafísico que nos aproxima de um sentido espiritual e sensível em detrimento ao materialista que o geógrafo formulou. Seria, assim, possível pensar na relação da taxação das mercadorias como uma relação em que o sacrifício do trabalho é resultado do que é tido como sagrado e, nesse caso, os espíritos cultuados? Newitt (1997: 83) segue com o argumento de que durante muito do século XVI, os mercadores portugueses e muçulmanos foram adaptados ao Monomotapa através de relações rituais e o comércio era encaminhado para as feiras oficiais, onde podia ser taxado.

Ao observarmos o mapa apresentado anteriormente podemos perceber áreas bastante fragmentadas, cujas relações de dominação nos parece de pequeno alcance ao compararmos à situação atual após a delimitação da fronteira nacional. São múltiplas etnias e relações comerciais e assim fica evidente que os europeus não chegaram em vazios demográficos e onde chegaram havia uma ordem organizacional estabelecida.

Outro autor que foi consultado e também trata desse período é Maia (2015). Em sua tese de doutorado, ao analisar as mudanças nas estruturas sociais do povo nyungwe ${ }^{12}$, Maia (2015) resgata o comércio realizado no Monomotapa, cujas principais atividades seriam a agricultura, artesanato e o trabalho em minas de ouro. A exploração desse minério, de acordo com ele, é precedente ao século $\mathrm{XVI}^{13}$, ou seja, anterior aos contatos

\footnotetext{
${ }^{12}$ Principal etnia da região em que se formou Tete e Moatize.

${ }^{13}$ O Império Monomotapa teria se formado depois do Great Zimbábue, também denominado de Estado do Zimbabwe que data entre 1250 e 1450 (SERRA, 2000, 31). Tal Estado teria se formado para controlar e tributar ouro extraído na região e o desenvolvimento da arquitetura daquele período permite que ruínas possam ser vistas até hoje naquela região (atualmente na área do Zimbabwe), abertas ao turismo: o Great Zimbabwe.
} 
com euro-ocidentais, mas ainda assim ligados a um comércio internacional de mercadorias que estava baseado na troca. Ouro e marfim eram trocados com abissínios (da atual Etiópia e Eritreia) por bois, sal e ferro (MAIA, 2015, 37). De acordo com ele, essa rota teve a dinâmica alterada com a expansão do Islã e a chegada dos árabes. A partir disso, a circulação deixou de ser continental e passou a ser marítima (idem, 39).

Maia (2015) segue o argumento de que aos portugueses interessava o comércio do ouro, pois o ouro era trocado por especiarias exóticas com a Índia (idem, 43) que por sua vez eram trocadas no mercado europeu. Assim para a circulação desses produtos e a reprodução das relações comerciais, os portugueses dependiam do minério ${ }^{14}$

Sendo assim, quando os portugueses chegam no Vale do Zambeze esse comércio marítimo já ocorria e com relações de poder estabelecidas que não eram necessariamente determinadas pelo dinheiro. Em 1597, os Carangas (do Império Monomotapa) solicitaram aos portugueses que estavam em Tete para os proteger contra a invasão dos maraves, são caracterizados pela historiografia consultada como Estado Marave (não Império). O Estado Marave era formado por migrantes da etnia Phiri, do atual Congo e, segundo a etnologia clássica, tinham tradição matrilinear ${ }^{15}$ (MAIA, 2015, 59). Tal Estado estava ao norte do rio Zambeze (margem esquerda), ou seja, onde atualmente está o distrito de Moatize e comercializava em grande escala enxadas de ferro, tecidos de algodão, além do marfim, o que colocava na divisão social do trabalho a organização de caça aos elefantes (SERRA, 2000, 62). Nessa altura, os portugueses aliaram-se ao Império Monomotapa como estratégia de um possível acesso ao ouro nessa região e, assim, para impedir o avanço do Estado Marave sobre o Império Monomotapa, os portugueses foram autorizados a entrar no território transportando armas (NEWITT, 1995: 84).

Não nos está claro como se dava a coerção ao trabalho nesse momento, mas a partir desse esboço compreendemos que os portugueses seguiam mecanismos já existentes e acreditamos que em processo, os portugueses envolveram-se nessas relações pré-coloniais e aos poucos desestruturaram antigas relações de poder, tendo a força militar como instrumento para validar seu poder.

\footnotetext{
${ }^{14}$ Vale lembrar que esse minério ainda não era explorado no Brasil, que iniciou no fim do século XVII e o auge foi apenas no século XVIII. Moura (2011) argumenta que nesse período a relação com o Brasil era de insignificância e os portugueses voltavam-se para a Índia (Goa) e Ásia portuguesa.

${ }^{15}$ Negrão diz que Moçambique é um dos poucos locais do mundo em que é possível estudar o sistema matrilinear. Esse sistema é caracterizado pela antropologia clássica como uma forma de casamento em que a mulher tem garantia do direito de acesso à terra. Após a sua morte, a produção e a conservação do que é produzido é de responsabilidade do tio materno, ou seja, transmitido para o filho mais velho da filha primogênita da mãe (NEGRÃO, 2000). Ou seja, por mais que seja um sistema matrilinear, o poder nos parece ser semelhantemente androcêntrico.
} 
De qualquer maneira, nesse período que compreendemos como um princípio de tentativa de colonização portuguesa, a intenção não se configura na exportação de trabalhadores europeus, nem na formação de mercado consumidor de produtos portugueses, mas conforme formulou Caio Prado Junior referindo-se ao Brasil, o sentido da colonização nesse caso em Moçambique, pensamos como pelo interesse na exploração de recursos naturais em proveito do comércio europeu.

É nesse processo que compreendemos que se formaram o que foi chamado de Prazos da Coroa. Newitt (1995) apresentou que durante o período que as relações estavam organizadas nessa particularidade, o acesso e controle da terra era por duas maneiras. A primeira entre os portugueses em que as terras eram cedidas mediante contrato de arrendamento com regras do direito romano: os prazos. A outra ele atribui a uma particularidade que se desenvolvia entre os próprios africanos, cuja relação de poder estava nas chefias locais. Para o autor, os prazos constituíam um complexo sistema de relações econômicas e sociais destinadas a aproximar os povos da região. Este caráter dualista é típico da cultura social e política dos Afroportugueses, a qual lhes permitiu viver e operar em dois (mesmo três) mundos ao mesmo tempo (NEWITT, 1995: 203).

Da parte que cabia aos portugueses nos prazos, eram áreas de grande produção cedidas à portugueses ou outros estrangeiros como os goeses (Índia portuguesa), por um período de três gerações. Newitt (1995: 205) considera que o objetivo de Portugal era extorquir tributos dos camponeses e não exatamente um processo de povoamento naquela região por portugueses, ou seja, naquele momento de acumulação interessava à Portugal explorar minérios para comercializar, minérios explorados por pessoas locais. Nesse sentido, esse momento é possível de ser pensado pela totalidade da relação como um momento de acumulação primitiva (Marx), pois cria a relação-capital. E vale dizer que em Tete haviam prazos que pertenciam também a jesuítas (NEWITT, 1997: 209- 210).

Entre as relações de acesso à terra, quem herdava os prazos eram preferencialmente as mulheres, donas dos prazos ou prazeiras, que a historiadora Rodrigues (s/d) aproxima do modelo colonial da Índia portuguesa, Goa, um Estado da Índia Portuguesa ${ }^{16}$, e diferencia em relação ao regime das sesmarias, no Brasil. Ela argumenta que a concessão de terra era principalmente para mulheres portuguesas que eram viúvas ou órfãs (RODRIGUES, s/d) e a condição era que elas deveriam se casar com nascidos em Portugal. Sendo assim elas eram disputadas entre homens que tinham

\footnotetext{
${ }^{16}$ O Estado da Índia Portuguesa foi colonizado por Portugal até 1961 quando foi retomado pela União Indiana que já estava independente da Inglaterra desde 1947 (JARDIM, 2006: 54).
} 
interesse em propriedade naquele território ultramar (ALENCASTRO, 2000: 17-18), os que viriam a ser os senhores da terra.

No entanto, a historiadora Spacachieri apresenta outro elemento importante desse momento: era proibido que mulheres viajassem de navio e isso limitava mulheres europeias naquela região, naquele período, o que contraditoriamente aumentava o número de viúvas e solteiras na metrópole. A historiadora argumenta que os homens portugueses que estavam onde hoje reconhecemos como Moçambique incorporaram relações de uma dinâmica local e isso inclui as relações sociais, relações de trocas. Nesse sentido, para ela quase todos se casavam com as filhas dos chefes locais africanos ou suas parentes próximas e constituíam as suas próprias famílias mestiças (SPACACHIERI, 2011: 9).

Newitt (1995: 211), por sua vez, diz que a sociedade afro-portuguesa encontravase claramente dominada pela mulher muzungo (mulata) de origem local, que acabava por contrair matrimônio ou com um português ou com um indiano. Por fim, Capela (2005:74) diz que entre todas as prazeiras conhecidas nenhuma consta com origem na Europa.

A propriedade da terra pertencia a uma mulher, mas quem chefiava era homem, o Mfumo. Ele era um líder cuja autoridade era reconhecida pelos moradores do lugar anteriormente às relações organizadas pelos portugueses, por isso essas chefias vieram a ser caracterizadas como tradicional, mas trata-se de uma forma ontológica que sugere que tais relações não tenham sido transformadas ao longo do tempo, como se fossem formas puras e naturais de relação. Ao ser chamada de tradicional, coloca ainda em oposição ao que é tido como moderno que é a organização estatal. Uma concepção epistemológica que reproduz de forma iluminista a sociedade capitalista e burguesa e, nesse sentido, aquilo que não identifica enquanto tal, pode ser, inclusive, considerado erroneamente como atraso.

Sine (1976) é um dos autores que volta sua crítica à essa compreensão burguesa desenvolvimentista que positiva o desenvolvimento - processo de modernização -, pois para essa compreensão é como se fosse necessário liquidar o que é tido como atraso, ou seja, tradicional e assim viria o desenvolvimento. $\mathrm{O}$ autor considera que tal perspectiva desvia a crítica da contradição interna do próprio sistema que, para ele, está na formação de classes sociais que é um resultado das relações de exploração e resultam numa relação de dependência. No entanto, esta crítica seria por si suficiente? Voltaremos a essa questão mais adiante na dissertação.

Ao fazermos uso do termo tradicional em alguns momentos da dissertação para nos referirmos a autoridade que estamos apresentando, fazemos com tais ressalvas. 
Mantemos o termo em alguns momentos por ser assim que essas chefias passaram a ser chamadas e ser maneira de diferenciar da autoridade estatal, além de ser assim que consta em algumas das referências bibliográficas que consultamos.

Pois bem, o Mfumo era uma autoridade que aparentemente foi instrumentalizada lentamente pelos senhores e donas dos prazos. A função dele nessa relação era fazer a mediação com os camponeses que viviam e trabalhavam nas terras, num encontro de, digamos assim, dois mundos, pois compreendemos que o que organizava as relações entre as pessoas locais e os estrangeiros tinham lógicas particulares. O Mfumo deveria cobrar dos camponeses um tributo anual, o mussoco e entregar para esses senhores do prazo ${ }^{17}$,

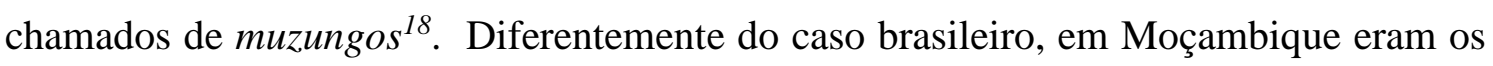
camponeses que eram chamados de colonos. Assim, os colonos pagavam a renda em produto (Marx) para os donos dos prazos: indianos e portugueses. Newitt (1995: 220) apresenta dados relacionados a esse pagamento em gênero e em Tete era realizado com milho e, como o clima de Tete dificultava o cultivo, a consequência foram migrações.

Para melhor esboçarmos a hierarquia que organiza as relações em que o Mfumo constitui enquanto liderança, ou seja, anteriormente e paralelamente à organização que os portugueses impuseram, recorremos à publicação do Ministério da Administração Estatal de Moçambique, com autoria de Ambrósio Cuahela ${ }^{19}$, para assim pensarmos no seu processo de cooptação e substituição por outra lógica. Cuahela (1996: 15-16) chama essa autoridade de tradicional e enfatiza as diferenciações do que constitui a hierarquia dessa autoridade entre as diferentes etnias ao longo da área que atualmente compreende Moçambique. Ou seja, não é possível dizer que há uma característica homogênea nessa lógica organizacional, mas é possível dizer que o Estado Nacional abrange uma área de diferentes organizações sociais na tentativa de as homogeneizar com as categorias da relação capital-trabalho, no processo de territorialização do capital.

De acordo com Cuahela, em Tete, no topo do poder está o Mambo $\left(1^{\circ}\right)$ : que é um espírito religioso e político do antepassado da linhagem. Ele não é concreto, não está

\footnotetext{
${ }^{17}$ Não nos está claro se poderia pagar para as donas dos prazos.

18 Ainda hoje, pessoas brancas ou mestiças são chamados de muzungos, ou mulungus. Em Tete, mais especificamente diz azungo. No dicionário Chisena-português, com autoria do padre Dionísio Simbe, por sua vez, o significado de mulungu é Deus.

${ }^{19}$ Historiador e Antropólogo moçambicano formado na Universidade Eduardo Mondlane (UEM) em meados dos anos 1990, mesmo período em que publicou a série de brochuras sobre Autoridade Tradicional em Moçambique. Sua formação básica foi no início dos anos 1990 na Faculdade para Antigos Combatentes e Trabalhadores de Vanguarda (FACOTRAV), criada no III Congresso da FRELIMO para a formação daqueles que foram guerrilheiros na Luta da Libertação e afinal abriu-se para outros estudantes (HENRIQUE, 1989: 6).
} 
vivo $^{20}$; Em seguida está o Nhakwawa $\left(2^{\circ}\right)$ : que é uma pessoa real, viva. Essa pessoa recebe os poderes do Mambo, numa relação em que estabelece uma mediação permanente entre os vivos e os mortos e seu poder é apresentado por Cuahela como sagrado. A função do Nhakwana é dirigir o território linhageiro ${ }^{21}$ com a ajuda dos Conselhos de Anciões. Os Conselhos, por sua vez, são formados pelos homens mais velhos da comunidade. Nessa conjuntura, o Nhakwana determina as formas de ocupação de terras pelas famílias e nomeia os chefes subalternos; Os Mfumos ( $\left.3^{\circ}\right)$ são esses subalternos e nos interessam particularmente por serem esses apresentados como figuras importantes nos prazos. $\mathrm{Na}$ apresentação de Cuahela (1996), os Mfumos tem como função resolver conflitos que não tem solução em nível familiar, determinar a época das cerimônias ${ }^{22}$ etc. Um Mfumo assume a chefia de mais de uma linhagem dentro do território linhageiro e ele escolhe os Mwananfumo, que deve ser aprovado pelo Nhakwawa. O Mwananfumo $\left(4^{\circ}\right)$, por sua vez, é chefe de uma linhagem.

Cuahela (1996) pontua ainda que na sociedade africana local não tinha chefes maiores que os chefes dos territórios linhageiros, ou seja, essa organização é compreendida de forma separada da autoridade estatal e o autor segue dizendo que $a$ estrutura sociopolítica africana local não exigia, ainda, nenhum título ou papel como o que foi outorgado ao régulo pelos portugueses (CUAHELA, 1996: 30 - grifo nosso por ser figura que iremos falar posteriormente), pois nessa organização a relação está baseada no testemunho e na oralidade, em detrimento à sociedade que o contrato se dá por meios escritos com a forma jurídica de reconhecimento da autoridade.

Ao Cuahela falar sobre a legitimação do poder do então chefe "tradicional", aparecem outras particularidades, pois ao mesmo tempo em que a legitimidade é colocada

\footnotetext{
${ }^{20}$ É importante dizer que é bastante comum nas situações cotidianas em Moçambique que conversas e relações permeiem o mundo dos vivos e o mundo dos mortos, ora mais explicitamente, ora menos. Como exemplo dessa relação, podemos lembrar que ao ser noticiado a morte de uma pessoa é comum não ser anunciado o fato como morte, mas sim o seu desaparecimento físico. "Em África, os mortos não morrem. Basta uma evocação e eles emergem para o presente, que é o tempo vivo e o tempo dos viventes" (COUTO, 2009: 130).

${ }^{21}$ O território linhageiro é definido por Cuahela (1996) como toda área geográfica com os seus limites geralmente naturais, como rios e montanhas, ocupada por muitas linhagens que obedecem ao mesmo chefe grande, o chefe "tradicional". Uma linhagem é composta por pessoas que tem o mesmo antepassado que normalmente é real, reconhecido através da tradição oral. Já a família é uma pequena unidade duma linhagem e constitui a base da comunidade. Cuahela (1996: 5), explica ainda que em algumas línguas esta unidade (família) corresponde à "todos nasceram da mesma barriga", mas geralmente considerada a família alargada, que abrange os tios, tias, avós, não apenas a família nuclear: pais e filhos.

22 "As cerimônias que consistem em oferendas dos vivos aos mortos, visam amainar ou evitar que os defuntos entrem em estado de raiva pensando que foram esquecidos ou, visam pedir que eles intercedam junto das outras forças sobrenaturais, na resolução de vários problemas que podem afetar a comunidade" Cuahela (1996: 38).
} 
como reconhecida pela própria comunidade e reafirmada em cerimônias, há o argumento de que o poder foi conquistado ou se eleva por simbolismos. A legitimação pode ser dada assim para aquele que chegou primeiro no lugar, pois essa condição lhe dá uma ligação maior com a terra onde estão enterrados os seus mortos. Pode ainda ser dada a legitimidade para quem tem uma linhagem mais influente. E o que seria influente? O autor exemplifica com situações tidas como problema e que por meio de um ato mágico ou com a violação de um tabu uma pessoa resolve esse problema. Então, não sendo da linhagem do chefe "tradicional", essa pessoa demonstra ter maior influência, conquistando sua legitimidade no poder.

Entre estranhamentos, essa é uma tentativa de acessar a forma organizacional do que é apresentado como autoridade tradicional e aquilo que lhe conferia poder, mas isso não significa que a partir dessa forma objetiva de apresentar e pensar nessas relações específicas seja possível acessar a pluralidade do que elas constituem.

Para lidarmos com esses estranhamentos, tomamos as formulações de Kurz (2014: 64), para olharmos para as distintas particularidades e assim cabe analisar as relações de fetiche. Para Kurz, as relações de fetiche pré-capitalistas não são possíveis de serem discutidas pelas determinações categoriais de Marx. Na mesma linha, nosso intuito na dissertação não está em ir ao limite para a compreensão dessas relações, visto que estamos lidando com as bases categorias capitalistas e, nesse sentido, a teoria e a própria compreensão de mundo pela forma científica que não oferece elementos para a análise e compreensão das formas de relação chamadas por Kurz de pré-modernas.

Ao trazer a hierarquia descrita por Cuahela, que conforme ressaltamos não são iguais em todo o Moçambique, nos parece importante por nos permitir tatear as relações hierárquicas nos Prazos e pensarmos em sua transformação com o processo de territorialização do capital que homogeneíza as relações. Compreendemos como uma hierarquia que passa pela relação de poder que podemos associar talvez erroneamente à espiritualidade, exatamente pelo nosso limite categorial de análise. Kurz atenta ao perigo de analogia dessa lógica que chama de pré-moderna (ainda que se refira à lógica pré moderna no continente europeu e em outro momento histórico) com a religião, pois não é uma relação meramente ideológica, ou questão de fé, mas uma lógica peculiar que dá forma na reprodução da vida humana terrena e nos seus modos de organização social (KURZ, 2014: 65), por mais que essa sociedade esteja longe de se entender a si própria como um modo de produção, pois produção e reprodução são, conforme as formulações do autor, expressões modernas. 
Com base nas reflexões do autor, compreendemos que o elemento reprodutivo que aparece e ao qual a autoridade dita tradicional organiza as relações não é a forma-capital com a produção de valor e a mediação pelo dinheiro. Então, em que consiste a essência dessa ordem hierárquica? Ao tratar sobre a lógica peculiar que Kurz chama de prémoderna (por ser pré-capitalista), Kurz formula que a essência está ancorada num princípio transcendente, não é empírico, pois está para lá do mundo perceptível que pode ser entendido como essência divina e o fundamento de todas as coisas e, nesse contexto, a hierarquia se estende de Deus (nesse caso nos parece ser um antepassado), até a matéria inanimada e no mundo humano tem de se legitimar perante os poderes superiores, invisíveis (KURZ, 2014: 67).

Kurz (1993: 235) lembra ainda que o termo fetichismo fundamentava-se nas observações de colonizadores portugueses na África e servia para designar uma crença que imagina em objetos mortos uma alma e forças sobrenaturais. Compreendemos que a analogia com o mundo da religião, que é uma expressão moderna, é pela ausência de elementos na relação social capitalista em que as relações são entre coisas. No entanto, essa relação que se coloca como metafísica, quando pensada pela dimensão histórica imprime a sua forma de reprodução da vida humana terrena e nos seus modos de organização social (KURZ, 2014: 65). Uma ordem objetivada com formas de autonomização $^{23}$ diferentes do mundo entendido como moderno, cuja essência dessa ordem é ancorada num princípio transcendente.

Aqui retomamos o Mambo, caracterizado por Cuahela (1996) como o espírito do antepassado, aquele supostamente que orienta a organização social e que constitui no terreno prático em relações sociais que derivam em rituais e sacrifícios. Retomando o argumento de Kurz (2014: 69), ele formula que:

Nunca os deuses nem o princípio divino estão empiricamente presentes ou são tangíveis no mundo.

Como Marx demonstrou, também o valor abstrato enquanto princípio social do moderno sistema de fetiche não pode ser apreendido como tal e de forma empírica em lugar nenhum, e nessa medida, contém em si um momento transcendente. Ainda assim ele é uma abstração real, que não só existe no

\footnotetext{
${ }^{23}$ No capítulo XLVIII do livro 3 do capital (A fórmula trinitária), Marx formula o processo de autonomização quando "os meios de produção monopolizados por determinada parte da sociedade, os produtos autonomizados em relação à força de trabalho viva e às condições de atividade exatamente dessa força de trabalho, que são personificados no capital por meio dessa oposição" (1996: 269). (...) E que "o processo real de produção, como unidade do processo imediato de produção e do processo de circulação, gera novas configurações, em que cada vez mais se perde o fio da conexão interna, as relações de produção se autonomizam umas em relação às outras e os componentes de valor se ossificam entre si em formas autônomas" (1996: 278).
} 
espírito humano, como surge de um modo físico-empírico sob a forma do dinheiro.

Ou seja, duas lógicas cujo fetiche da primeira não é material, mas tem como essência o que é posto a partir dos deuses, enquanto no segundo, o fetiche é o da mercadoria e tem uma mediação material na forma do dinheiro, a sociedade da mercadoria que tem como essência o valor. Assim, o princípio do fetiche outrora transcendente imigrou para a manifestação, terrena e bem tangível, do dinheiro (idem: 68).

Dito isso, acreditamos que seja perigoso igualar nos mesmos termos e princípios aquilo que organiza as relações. Para nós interessa sobretudo o que aparece como dominação sob a abstração da forma valor que estava em processo de formação, mas não é possível necessariamente demarcar daquilo que está pautado pela abstração de princípio divino ou o momento em que se dá essa transição.

A bibliografia consultada sobre Moçambique aponta hierarquias que constituem a chefia tradicional pela forma concreta e como elas organizam as relações. O poder, que pode ter como essência diferentes princípios, é igualado em sua forma aparente e personificado na autoridade definida como tradicional e também na autoridade em formação que é a autoridade estatal. Essa última veio a ser chamada de administração colonial. Assim compreendemos que nos Prazos essa autoridade formada tende a organizar e controlar os colonos (camponeses) e os escravos para os senhores e donas dos prazos.

Acreditamos que seja nessa conjuntura que Alencastro (2000: 19) formula que há diferentes formas de organização social e controle do território numa mesma área e que a exploração colonial não é necessariamente a dominação colonial, pois a presença de colonizadores num território não assegura a exploração econômica desse mesmo território, dando assim o tom do processo que caminha lentamente, com as estruturas e relações que são transformadas pelo processo de territorialização do capital com a imposição das relações capital-trabalho.

Compreendemos que a administração colonial estava entre os senhores dos prazos, ou seja, da terra e os que são apresentados como escravos. Sobre a relação do trabalho escravo, o historiador Michel Cahen (2015) diferencia dois modelos do trabalho escravo em Moçambique. O primeiro estava no comércio internacional e o autor define como escravagismo cuja relação seria no contexto do trato dos viventes. Um comércio que no contexto do tráfico de pessoas que foram escravizadas é considerado tardio naquilo que 
abrange Moçambique. Capela \& Medeiros (1989: 184) atribuem ao comércio do marfim o tardio comércio internacional de pessoas escravizadas cuja origem era de Moçambique:

Durante o século XVII e bem avançado XVIII, a maior lucratividade do comércio do marfim com a Índia não estimulou o desenvolvimento do tráfico de escravos em grande escala, como ocorrerá na primeira metade do século XIX. Este mesmo fator fez com que historicamente o grosso comércio negreiro da região se tenha efetuado com as ilhas do Índico (Maurício, Reunião, Madagáscar, Comores, Seychelles) e em menor proporção com o Brasil e o continente americano.

Capela e Medeiros apresentam ainda duas particularidades: a presença de negreiros árabes (que os portugueses não conseguiam expulsar) em todo o litoral norte que eram comerciantes e que o autor considera como aliados aos chefes tradicionais. Esses escravizariam e vendiam na esteira das caravanas de marfim.

Para Cahen os recrutamentos eram compulsivos e feitos pelos chefes locais e os administradores das circunscrições (divisões administrativas coloniais) que recebiam uma indenização pelo recrutamento ${ }^{24}$. Essa relação de comércio internacional se encerrou apenas em 1902.

A outra forma do trabalho escravo, seria no contexto da reprodução de relações locais, domésticas e produtivas. Cahen (2015: 140) apresenta que antes da chegada do automóvel, era obrigação dos chefes tradicionais de fornecer homens para portagens e essa obrigação seria uma prática de caravanas comerciais com centenas de escravos portadores que iam do interior para a costa. Eram essas pessoas ainda que trabalhavam na extração de ouro, na movimentação das mercadorias e era quem trabalhava nas casas dos senhores e donas dos prazos todos na condição de escravos.

Essas pessoas seriam capturadas por outros escravos, os achikunda, que tinham a particularidade de ser considerados como exército dos senhores dos prazos. A historiadora Spacachieri (2011) define os achikundas como escravos armados que faziam o policiamento nos prazos, cobravam os impostos enquanto eles mesmo não os pagavam, numa relação que nos faz lembrar da figura do capitão do mato no contexto brasileiro ${ }^{25}$.

\footnotetext{
${ }^{24} \mathrm{O}$ autor não oferece maiores detalhes do que seria essa indenização e, por ser também um ponto sensível na historiografia, não temos base para discutir o que mobilizava os chefes tradicionais, no sentido que atribuíssem necessidade para essa relação, ainda que situações de coerção e violência contra eles sejam registradas.

25 "No fim, ou mesmo durante o sistema de prazos, os achikundas fugiram para longe dos seus postos de trabalho, e aí formaram suas comunidades onde se organizavam segundo a tradição local" (CUAHELA, 1996: 22). Essas comunidades eram chamadas de aringas que o historiador José Capela faz paralelo aos quilombos no Brasil. E diz que depois da abolição da escravidão, os achikundas passaram a se chamar cipaios (CAPELA, 2005: 82).
} 
Newitt oferece um panorama da forma aparente da época ao apresentar o estranhamento do médico e missionário Livingstone:

Muitos observadores, entre eles Livingstone, que se deslocou a essas paragens em meados do século XVIII, mostravam-se perplexos perante a imagem de africanos a oferecerem-se para serem vendidos como escravos, mas por esta altura, o facto transforma-se numa prática comum na Zambézia. $\mathrm{O}$ acto de se ligar a uma das grandes casas afro-portuguesas podia ser entendido como uma estratégia de sobrevivência em tempos de fome ou guerra, mas há também que considerar a hipótese de se tratar de uma forma de prosperar e subir na vida, uma vez que os senhores do Zambeze recorriam aos serviços dos escravos para gerir as suas casas, cobrar impostos aos colonos, chefiar missões diplomáticas ou efetuar algumas expedições comerciais (NEWITT, 1995: 217 - grifo nosso).

Naquilo que é visível nem sempre aparece o que mobiliza ao trabalho e pode aparecer como uma relação espontânea, mas Newitt oferece elementos daquilo que poderia levar às relações de subordinação. Assim, tanto Newitt (1995) quanto Cahen (2015) apresentam as relações de dominação, definidas como de escravidão, como relações que se desenvolviam na própria sociedade africana e que se intensificaram durante o período colonial, já inseridas no sistema capitalista.

Sobre a produção nos prazos, diferentemente do que ocorreu no Brasil, Cahen (2015) pontua que o que era cultivado não estava organizado para a exportação e sim para a reprodução local, não havia plantação organizada sistematicamente para a exportação (CAHEN, 2015: 138-139), pois a posse direta de terras no interior era débil e espacialmente muito reduzida (...) e a rentabilidade das plantações brasileiras e santomenses impedia produtos africanos continentais de competirem. A produção agrícola estava assim para a reprodução de práticas locais: para comércio em aldeias de escravos, para o sustento dos proprietários locais, abastecimento de navios. O rendimento dos senhores dos prazos (e vale reforçar que os prazos não eram controlados em sua totalidade por portugueses) estava no comércio, no garimpo do ouro, nos transportes pelo Zambeze. A principal mercadoria de exportação no período era o marfim (CAPELA, 2005) e este comércio era dominado pelos indianos ${ }^{26}$, os maiores concorrentes no capital mercantil.

\footnotetext{
${ }^{26}$ Newitt (1997) aponta que em 1766 havia em Tete 8 casas importantes e 3 delas eram de famílias indianas além de a maioria do comércio na cidade ser de indianos, assim como em todo o Moçambique conforme argumenta Jardim (2006: 148). Com base em Newitt, ela sintetiza a importância indiana na inserção da África no sistema mundial de produção e circulação de mercadorias, ao serem eles que financiavam o
} 
Assim, Portugal não realizou forte acumulação primitiva nesse período que desse condições para ampliar as relações comerciais inclusive no próprio continente. Então por um lado, abre-se ao capital internacional com o arrendamento de terras para as Companhias Concessionárias ou Companhias Majestáticas. Por outro lado, utiliza-se do trabalho forçado (chibalo). Bragança \& First (1981) argumentam que essa estratégia é manifestação da própria debilidade do Estado e capitais portugueses, incapazes de competir no mercado regional de trabalho. E isso é o que discutiremos no próximo item.

\section{(chibalo) \\ 1.3. O auge da colonização e do trabalho explicitamente forçado}

O mapa que apresentamos no início do item anterior mostra a área dos Prazos e eles estão datados entre o século XVI até os anos de 1930 (NEWITT, 1997: 203), ou seja, até o Estado Novo português. No entanto, há uma mudança significativa no final do século XIX, com a entrada do capital financeiro no sistema produtivo e uma nova posição dos Estados Nacionais europeus no controle do território no continente africano com a formação do Estado Colonial. Essa mudança na dominação e controle do território, com a ocupação efetiva de Moçambique, foi oficializada na Conferência de Berlim (1885) em que o controle do território foi demarcado apenas entre os países europeus, excluindo dessa disputa, por exemplo, os árabes que tinham e mantiveram grandes relações comerciais marcadamente em Moçambique. É a partir desse momento que dirigem-se à colônia moçambicana mais comerciantes da metrópole portuguesa, seguidos pelas companhias estrangeiras, as Companhias Concessionárias do século XX.

Moçambique é um país cercado por países que foram colonizados pela Inglaterra: as Rodésias ${ }^{27}$ do sul e do norte (atual Zimbábue e Zâmbia) e Niassalândia (atual Malaui). Colônias britânicas que dependiam de Portugal para ter saída para o mar por Moçambique e exportar mercadorias, ao mesmo tempo em que Portugal precisava de capital inglês para ocupar efetivamente Moçambique. O que resultou em sucessivos acordos entre Portugal e Inglaterra para a consolidação da produção e circulação das mercadorias de origem do país britânico. Além dessas colônias havia a imensa África do Sul, também fronteiriça à Moçambique e colônia britânica.

comércio, a navegação e a compra de excedentes dos agricultores, além da arquitetura moderna (Jardim, 2006 :42).

${ }^{27}$ Nome que faz referência ao imperialista Cecil Rhodes. 
A dependência portuguesa com relação ao capital inglês submetia-os aos interesses do Império ${ }^{28}$. A própria delimitação do que veio a ser Moçambique é resultado de uma série de tratados internacionais assinados entre Portugal e Grã-Bretanha em 1891 (NEWITT, 1997), com o compromisso de construir a linha férrea que dava acesso da Rodésia do Sul à cidade portuária da Beira em Moçambique (BRITO, 1980: 25).

O britânico Livingstone (1813-1873) iniciou suas expedições nessa região da África Austral por volta dos anos de 1850. De acordo com Newitt (1997: 259), o médico missionário atravessou de Angola à Moçambique e parte dessa travessia fez descendo pelo rio Zambeze. Após isso publicou o livro Missionary Travels que constituiu o primeiro relato detalhado sobre os assentamentos afro-portugueses na Zambézia e teria estimulado a expansão das missões anglicanas e a entrada dos britânicos na região do Zambeze.

Independente se é a partir do que ele registrou ou se a própria expedição tenha sido encomendada, a exploração mineira em Tete que já vinha em processo ganhou novos contornos a partir desse momento. Em sua dissertação de mestrado, Inês Miguel (2009: 49) argumenta que Livingstone é considerado entre os primeiros, se não o primeiro, que publicou sobre o carvão em Tete (em 1857) e considerou essa área como potencialmente mineira, o que certamente era uma informação de interesse para os ingleses, pois o carvão mineral era o recurso utilizado para a geração de energia que movia as máquinas da grande indústria na Inglaterra.

Nessa mesma época, Cecil Rhodes (1853-1902) personificava o imperialismo britânico na região da África Austral e ele mesmo se posicionava enquanto tal. Ele foi ministro da Colônia do Cabo (Cabo da Boa Esperança, na atual África do Sul) no final do século XIX (NEWITT, 1995: 85) e a expansão de sua política fez parte da territorialização do capital com a formação das Rodésias. Lênin (2011: 202) argumentou que Rhodes justificava a imposição das relações capitalistas e a expansão territorial britânica com a finalidade de evitar uma possível guerra civil na Inglaterra visto que o país tinha muitos desempregados. O período de intensificação da atuação de Rhodes esteve entre os anos de 1860 e 1890. Os políticos coloniais, conforme o próprio Rhodes se posicionava, apoderavam-se de novos territórios para enviar o excedente de ingleses, então já expropriados. Com isto formava novos mercados para os produtos das fábricas e das

\footnotetext{
${ }^{28}$ É válido lembrar que foi nesse período, início do século XIX, que foi acordada a independência do Brasil por meio de uma compra para que os portugueses de Lisboa pudessem pagar juros à Inglaterra (MOURA, 2011).
} 
minas da Inglaterra. Lênin apontou a ironia de Rhodes que, ao supostamente tentar evitar uma guerra civil na Inglaterra, foi responsável pela Guerra Anglo-Boer entre 1899 e 1902 (LÊNIN, 2011: 204).

Com base nas formulações de Lênin (2011), compreendemos tal expansão enquanto política imperialista que, a partir da fusão do capital industrial com o capital bancário inglês, formou uma oligarquia financeira. Essa oligarquia inglesa influenciou em Moçambique por meio das Companhias, que eram consórcios privados que arrendavam as terras portuguesas, além de realizar empréstimos com os quais Portugal conduzia principalmente a construção de infra estrutura pelo país.

Para o pesquisador moçambicano Brito (1980: 24) ${ }^{29}$, a necessidade que Portugal tinha de emprestar da Inglaterra estava por não ter realizado uma forte acumulação primitiva durante a fase do capitalismo mercantil e isso o diferenciava da Inglaterra. Para o autor, o capital mercantil indiano ${ }^{30}$ foi um forte concorrente no que diz respeito à Moçambique. Assim o argumento do autor joga luz na concorrência em relação ao comércio e na dificuldade de Portugal se impor no capitalismo financeiro. Compreendemos que a formulação dele está no sentido de que outros países europeus acumularam capital, o que garantiu a possibilidade de investir em novos ciclos de acumulação no que veio a ser o capitalismo monopolista.

Essa diferença coloca Portugal de forma retardatária no processo de modernização, pois enquanto Portugal não tinha capital para investir nas colônias, não conseguia realizar uma exploração sistemática e por isso nessa relação estava na posição de arrendatário, apropriando da renda da terra. É nessa relação de arrendamento que estão as Companhias que funcionavam com capital estrangeiro. Do Vale do Zambeze, todos os prazos na margem sul ficaram na concessão da Companhia de Moçambique [...], enquanto no distrito de Tete 126 dos 134 prazos estavam arrendados à recém formada Companhia da Zambézia (NEWITT, 1995: 329).

Nessa territorialização do capital por meio das Companhias, Tete ficou sob liderança da Companhia da Zambézia dominada inicialmente por Albert Ochs, um judeu de ascendência belga, que também tinha ações da Companhia de Moçambique. O argumento de Newitt (1995: 329) é que ele teria a intenção de competir politicamente e comercialmente com Cecil Rhodes que ameaçava disputar a área onde se formou a

\footnotetext{
${ }^{29}$ Pesquisador do Centro de Estudos Africanos da UEM.

${ }^{30} \mathrm{O}$ comércio de marfim foi dominado pelo capital indiano e constituía o maior setor nos portos e povoados do Zambeze e todas as normas comerciais provinham da Índia (NEWITT, 1995: 324).
} 
Companhia de Moçambique. Nesse processo, a área em que estava para a Companhia da Zambézia, por ser de difícil administração, teria sido aos poucos dissolvida e a área arrendada. Apresentamos no mapa abaixo a localização das Companhias e chamamos atenção do leitor para a Província de Tete e para a área de controlada pela Sena Sugar.

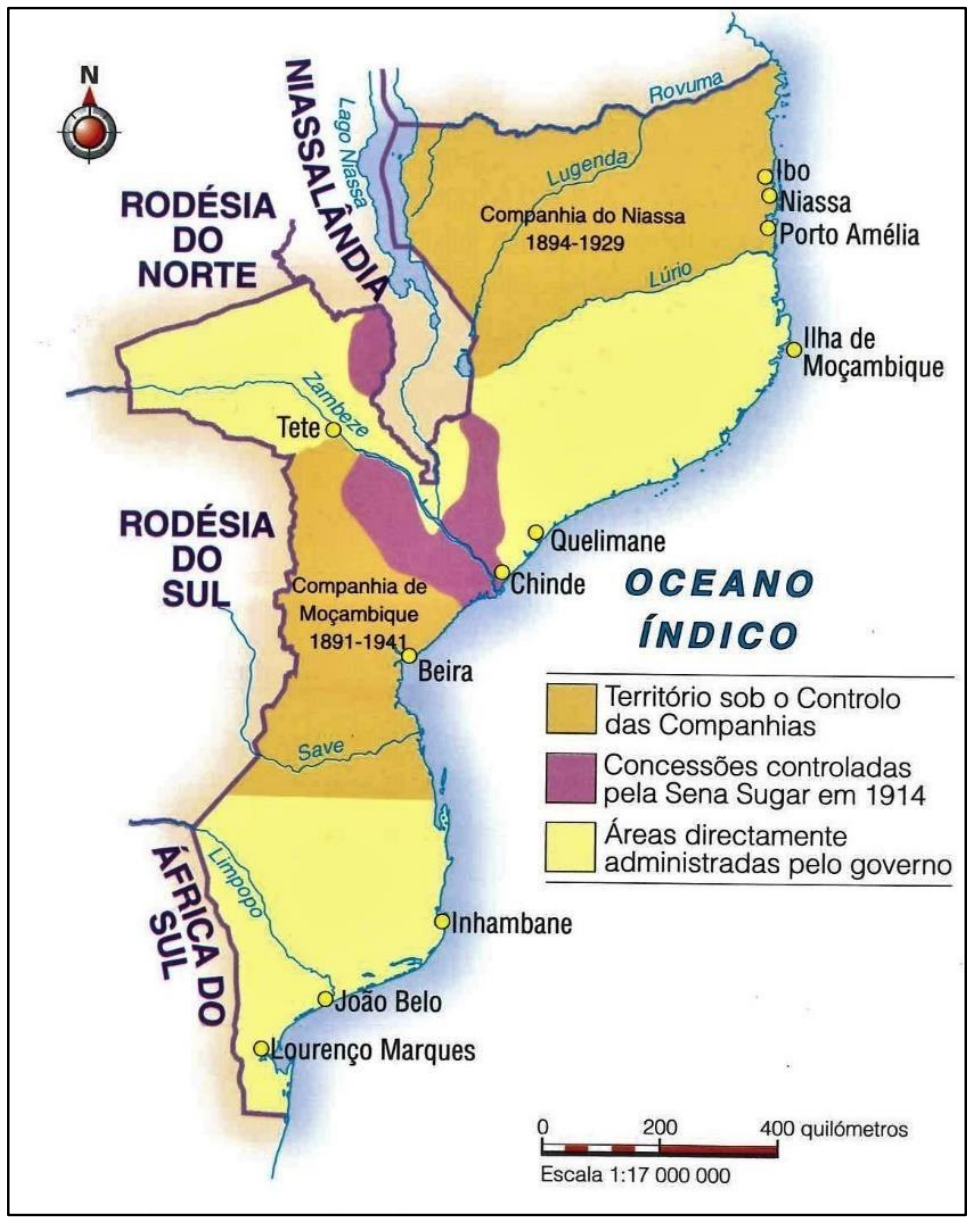

Figura 2: Mapa das Companhias - Economia colonial. Fonte: Atlas de Moçambique. Editora Nacional de Moçambique

O mapa acima caracteriza a área em que Tete está localizado como uma área diretamente administrada pelo governo e de forma homogênea. No entanto, o mapa abaixo coloca a multiplicidade de relações naquela suposta região, ainda que possa corresponder ao período de início da invasão colonial efetiva. 


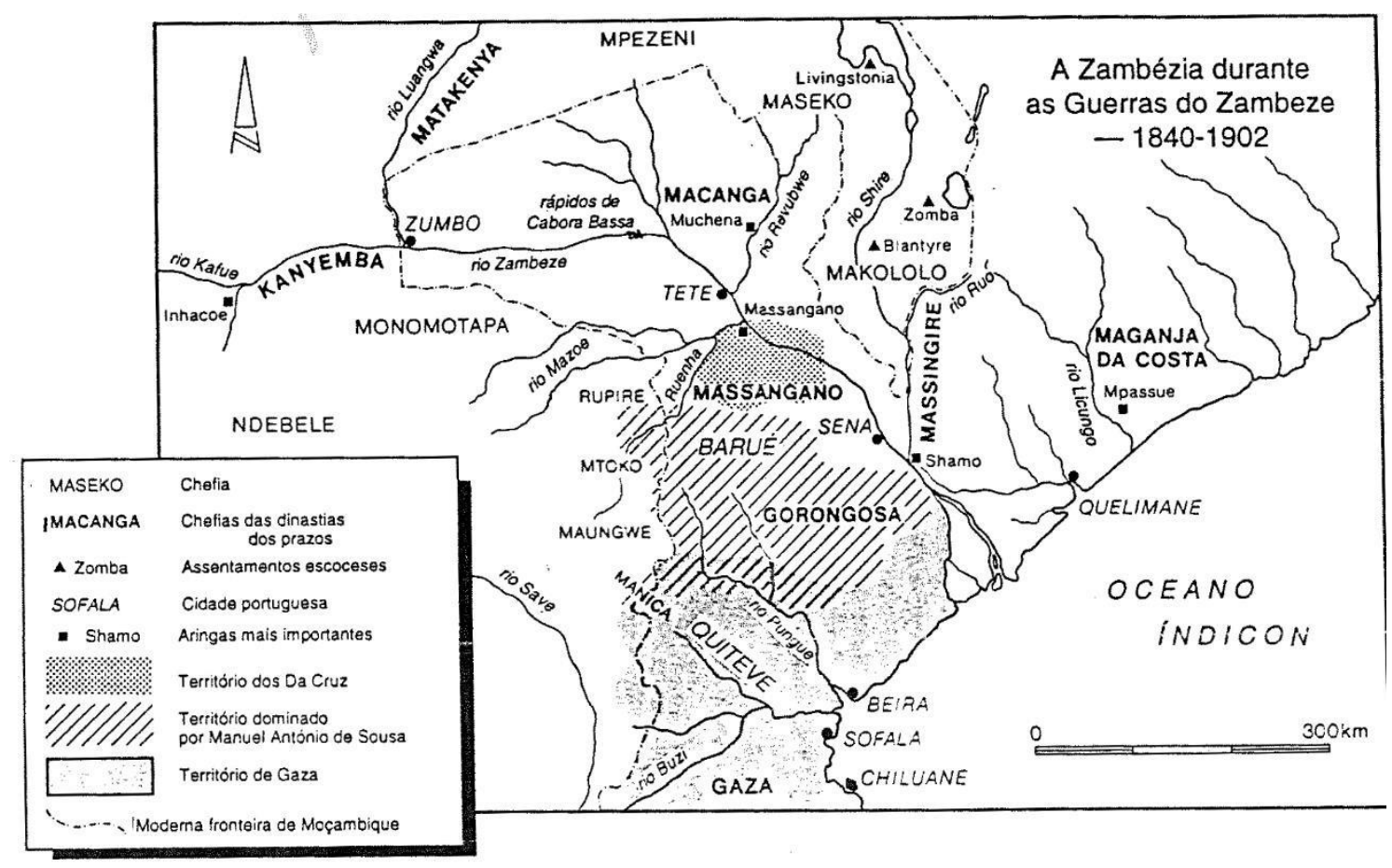

Figura 3: Representação da área entre 1840 e 1902. Fonte: Newitt, 1997: 284

A partir da bibliografia consultada, o que compreendemos é que no período das Companhias com capital estrangeiro, os prazos estão em declínio, ainda que não extintos, e uma nova forma de acumulação se impõe com capital estrangeiro e empresas privadas. As empresas com sua nova forma de produção por sua vez, transformaram as relações de trabalho, então consequentemente compreendemos como um período de transição na região ${ }^{31}$ (OLIVEIRA, 1993).

A base da produção nos prazos foi definida como trabalho escravo. Nesse novo momento de reprodução com as Companhias Concessionárias, a base da produção foi caracterizada pela historiografia consultada como trabalho forçado, também conhecido como chibalo, o que formulamos como um trabalho explicitamente forçado.

Além das Companhias que eram essas áreas de concessões de terras, havia as plantations (algodão, arroz, rícino) ${ }^{32}$. Na província de Tete tinha ainda a Sena Sugar Estates, conforme mostra a Figura 2 e chamamos a atenção do leitor. Essa empresa

\footnotetext{
${ }^{31}$ Francisco de Oliveira, ao pensar sobre o processo de modernização brasileiro nos anos 1970, formula o que toma como elemento para análise e aquilo que forma a região: a divisão regional do trabalho sob a ótica do processo de acumulação de capital e de homogeneização do espaço econômico do sistema capitalista. Compreende assim a região pela especificidade da reprodução do capital e as formas de conflito social (OLIVEIRA, 1993: 25; 27-28). Ele formula ainda como enclaves as regiões ligadas ao comércio internacional de mercadorias, cuja articulação entre si foi débil e que permitia às potencias imperialistas a criação da multidão de pequenos países hoje independentes. Estaria assim Tete numa região de enclave?

${ }^{32}$ Hedges chama de culturas de rendimento e Newitt chama de culturas forçadas.
} 
arrendou os grandes prazos de Angônia. De acordo com Head $^{33}$ (1980), essa foi a empresa privada que mais mobilizou pessoas para o trabalho. A Sena Sugar Estates pertenceu a John Peter Hornung que a princípio tinha intenção de produzir ópio, mas afinal produziu cana de açúcar e com financiamento da Inglaterra.

A mobilização pelo trabalho explicitamente forçado foi instituído juridicamente como negação do que vem a ser vadiagem pela Lei do Indigenato, uma medida jurídica aplicada em todas as colônias portuguesas (com algumas variantes) para definir as pessoas que estariam submetidas ao trabalho forçado, que poderia ser remunerado ou não. A primeira lei foi promulgada em 1878 e passou por alterações (1899: após a Conferência de Berlim; 1914: período do início das atividades na Sena Sugar Estates e produção de algodão; 1926: período próximo ao auge da colonização; 1954: quando o trabalho explicitamente forçado começa a ser criticado internacionalmente; 1962: início dos movimentos de libertação). A legislação regularizava o trabalho (explicitamente) forçado ao proibir a vadiagem, ou seja, as práticas de reprodução que não passavam pelo trabalho abstrato não eram consideradas. Assim, os "vadios" deviam ser submetidos ao "dever moral do trabalho" de acordo com o código de 1899, o que veio a se tornar "dever moral e legal do trabalho" no código de 1914 (CAHEN, 2015: 144).

A definição do que era considerado trabalho ficou mais evidente em 1928, já no período salazarista e fascista em Portugal. Ficou definido em termos jurídicos que trabalho é:

Profissão, arte ou ofício auferindo rendimento necessário para o sustento próprio e das pessoas da família a seu cargo [...] ou que possuísse bens suficientes para o mesmo fim. Estes “bens" são definidos, por sua vez, em termos de propriedade individual como, por exemplo, 5 ha de terra ou 100 cabeças de gado, o que era raríssimo na sociedade indígena onde a riqueza, quando havia, não era assim definida (CAHEN, 2015: 144 - 145).

Então a imposição do trabalho abstrato está posta. Agricultores tinham o dever moral de comprovar atividades que não fossem de subsistência e eram coagidos à sociedade da mercadoria em que o trabalho tem o fim em si mesmo. Kurz (1993: 28) apresenta essa transição como momento de substituição de simples componentes do metabolismo entre os homens e a natureza, que serve para a satisfação das necessidades. E passam a servir apenas para a auto-reflexão tautológia do dinheiro como mais dinheiro.

\footnotetext{
${ }^{33}$ Pesquisadora do Centro de Estudos Africanos (CEA) da Universidade Eduardo Mondlane.
} 
Nesse momento, a relação capital-trabalho foi imposta juridicamente, pois ao não comprovar trabalho (abstrato) e não tendo a riqueza no sentido que foi definida pelos iluministas burgueses, os homens poderiam ser capturados pelos cipaios (antes chamados de achikunda) e enviados forçadamente para alguma posição de trabalho que poderia ter uma finalidade adversa dentro das práticas que realizavam.

De acordo com Head \& Manghezi (1981) eram três tipos de trabalho em que era empregada essa força de trabalho: para agências governamentais e municipalidades; reparação de danos causados por calamidades e serviços ligados às condições de vida dos nativos e à agricultura, incluindo manutenção de estradas. Cahen (2015) aponta que nas próprias plantations e Companhias havia trabalho explicitamente forçado.

Durante o governo centralizador e ditatorial de António de Oliveira Salazar (19321968), o Estado Novo português assumiu medidas protecionistas para maior controle do território sobre as colônias africanas, sobretudo com força militar ${ }^{34}$ e intensificou a imposição do trabalho e cobrança de impostos naquele pós crise de 1929. Esse período é considerado como o auge da colonização em Moçambique: entre 1930 e 1961 (HEDGES, 1999) e com isso podemos também considerar como um auge de violência extra econômica aplicada para mobilização para o trabalho.

Durante o auge da colonização em Moçambique, Portugal tomou empréstimos com a Inglaterra para realizar o novo planejamento estatal e aplicou na construção civil em obras ao longo de Moçambique, obras de interesse da metrópole para circulação e exportação da produção interna. Foram construídas ferrovias, estradas e pontes ${ }^{35}$. Em Tete houve a construção da ponte sobre o rio Zambeze (construída entre 1933-35), seguida da construção dos Caminhos de Ferro que ocorreu entre 1938 e 1949, cujo longo tempo de construção foi justificado pela interrupção por causa da $2^{\text {a }}$ Guerra Mundial que provocou falta de equipamentos (HEDGES, 1999: 109). Esse trecho da ferrovia conectou Moatize à linha que já dava acesso ao porto da cidade da Beira, construída no período da Companhia de Moçambique, a Trans-Zambesia Railway. Lembrando que Tete/ Moatize está numa região nodal e uma estação de trem nesse ponto poderia ser de interesse não apenas de Portugal como também da própria Inglaterra.

A partir de 1938, durante o auge da Segunda Guerra Mundial, o regime salazarista aumentou a violência na colônia Moçambique com o uso do aparato policial para

\footnotetext{
${ }^{34}$ Aqui lembramos o leitor que foi esse governo que inspirou Getúlio Vargas no Estado Novo brasileiro.

${ }^{35}$ Aquino de Bragança argumenta que a cidade de Lourenço Marques, atual Maputo, foi construída em grande medida pelo chibalo.
} 
imposição das relações de trabalho e consequentemente aumentar a produtividade das mercadorias de interesse. E esse é um período que já está mais fortemente marcado na memória de meus interlocutores em pesquisa de campo.

Alguns moradores dos reassentamentos da Vale S/A relataram que pessoas de Angônia $^{36}$, Macanga e Chiparo foram levadas forçadamente à Moatize. Um deles narrou que as pessoas (e acreditamos que principalmente homens) eram colocadas em carros sem que pudessem ver o destino e assim eram levadas para trabalhar. Outro interlocutor explicou a particularidade:

O tempo era obrigado a recolher a pessoa obrigatoriamente. Eu estava aqui em casa e não trabalho, então chegava aqui e recolhiam-me a mim para ir trabalhar. Aquele que não pagasse o imposto era recolhido para poder pagar o governo. O Conselho de Administração cobrava o pagamento uma vez por ano. (ARNALDO, 2017).

Consideramos que o processo durante o auge da colonização recai empiricamente pelo uso da força militar e outros mecanismos de coerção, com a desestruturação daquilo que Kurz (2014) chama de panteão mágico-religioso ou aquilo que é chamado por Cuahela (1996) de autoridade tradicional que guiam os corpos por crenças e rituais. Foi a maneira que o Estado colonial foi instalando os administradores, chefes de postos portugueses e os que vieram a se chamar de régulos. Esses são popularmente chamados de chefes "tradicionais" e aqui lembramos a contradição do termo, pois nessa passagem fica explícita uma mudança na relação e termo tradicional pode sugerir erroneamente uma relação ontológica, como se não tivesse tido interferências passadas.

Se os Mfumos eram definidos pela hereditariedade e pelo Nhakwawa a partir do que o Mambo determinava, ou seja, pela essência divina, os régulos diferentemente eram escolhidos pelo próprio regime colonial que substituía os antigos chefes (HEDGES, 1999: 2), mudando a essência da relação que já está determinada por outra relação de poder: agora é o poder do Estado quem determina a autoridade para a reprodução do capital.

Diante dessa mobilização explicitamente forçada para o trabalho, o leitor pode estar se perguntando sobre a resistência. Seguindo no argumento que estamos apresentando, há uma lógica peculiar representada pela chamada autoridade tradicional que organiza as relações. Essa estrutura da sociedade em modernização se mantém ao longo de todo esse período ainda que os portugueses tenham mantido o desejo e estratégia

\footnotetext{
${ }^{36}$ Angônia era área de concessão controlada pela Sena Sugar que funcionou entre 1914 e 1950.
} 
de cooptar. Em trabalho de campo, outro de meus interlocutores narra como ele lembra a violência que era aplicada:

Os portugueses? Não eram para brincar. Para você dominar aqui você vai ter que matar o seu pai. Portugueses? Basta dizer que meu pai é inteligente, um régulo, basta ouvir assim, ele dá muita coisa até você arranjar pessoas para matar o seu próprio pai, para então você ser chefe. Tem que ser corajoso. Os portugueses faziam assim. Aqueles sabiam nacionalizar. Aqui não era país, era Província de Moçambique. Capital: Lourenço Marques. (LIONEL, 2017)

Com base nas formulações de Heidemann, Toledo, \& Boechat (2014), esse relato é por nós compreendido como processo de territorialização do capital, em que as estruturas e personificações estatais durante o regime colonial são a materialidade do que organiza as relações para a produção capitalista e a formação das relações de trabalho. Esse processo se realiza pelo uso da violência tanto econômica quanto extraeconômica. E então para meu interlocutor, esse processo aparece como "nacionalizar".

Para Cuahela (1996: 29), os régulos fazem parte de um momento da colonização que assumiu novas características, pois o mecanismo da comunidade já havia sido alterado. De acordo com ele, os régulos já colaboravam com as autoridades coloniais, como uma espécie de auxiliar da administração pública e faziam a mediação entre a comunidade e a administração colonial. Seriam assim os antigos Mfumo após sua instrumentalização? Cuahela segue:

Este processo de colaboração das autoridades tradicionais com o regime colonial, é deliberadamente designado instrumentalização (forma de fazer agir alguém sem consciência própria) porque, efectivamente, muitos Chefes Tradicionais passaram a perder aquele prestígio que as comunidades lhes conferiam. Passaram a ser designados Régulos ou Regedores que foi uma forma pejorativa para significar Rei Pequeno porque, segundo os portugueses, os verdadeiros reis estavam na Europa (CUAHELA, 1996: 29).

Pela mudança na essência, a autoridade atravessa um período de não reconhecimento pela comunidade. Nesse processo de transição das relações de hierarquia nas comunidades, Cuahela diz que a principal diferença entre os Mfumos, e os régulos estava na legitimidade, pois enquanto aos primeiros essa legitimidade era dada pela comunidade, aos segundos eram os portugueses quem lhes davam e, nesse sentido, nem sempre os régulos fazem a ligação entre o mundo dos vivos e o mundo dos mortos (CUAHELA, 1996: 31), pois perdeu a relação transcendental. Além disso, diferentemente dos Mfumos que buscavam apoio junto à sabedoria dos mais velhos da comunidade (o 
Conselho de Anciãos), os régulos tinham apoio de policiais locais, os cipaios, por exemplo.

Nesse sentido, os régulos tinham um papel importante naquele auge da colonização: ficavam incumbidos de cobrar o imposto indígena dos agricultores exigidos pelo regime. Imposto que era proibido ser pago em espécie (CAHEN, 2015: 146), ou seja, a renda nesse momento já era cobrada em dinheiro, obrigando-os a buscar maneiras de obter dinheiro para pagar os impostos e não sofrerem punições, que poderia ser o trabalho explicitamente forçado (chibalo) ou a prisão. Ao não pagarem os impostos, os agricultores eram recrutados pelos cipaios ou pelos administradores para o trabalho forçado nas empresas ou para os trabalhos públicos da Administração ou ainda para as machambas dos colonos (CUAHELA, 1996: 33), as plantations, o que constituía como uma punição.

No entanto, Head (1980) apresenta que os cipaios e os administradores tinham uma meta definida pelo Estado com o número de trabalhadores que eles deveriam recrutar e designar para as Companhias, ou seja, era necessário que alguém infringisse a lei para que a meta fosse cumprida. Contraditoriamente, toda essa violência aparece como aquilo que dignifica o homem, um dever moral. O geógrafo português Oliveira Boleo escreveu em 1951 referindo-se à Moçambique:

É preciso ter em conta que o indígena é mais um inadaptado (mas que facilmente se adapta) do que um preguiçoso. Torna-se necessário, portanto, ensiná-lo pacientemente, incutindo-lhe na inteligência a verdade de que o trabalho dignifica o homem e constitui uma obrigação (BOLEO, 1951: 341).

O geógrafo mostra-se assim alinhado à política colonial em que a ciência é instrumento do Estado. No livro intitulado "Moçambique", esse autor caracteriza o território ultramar pelos seus aspectos físicos e, ao falar sobre as pessoas que nele vivem, as chama de mão de obra, num tom bastante utilitarista e de objetificação dessas pessoas. Com isso sugere uma estratégia que ele chama de princípio da obrigatoriedade moral de trabalhar com a criação de necessidade ao indígena, impondo a obrigatoriedade de, por exemplo, se "vestir com decência" o que seria uma maneira indireta de o fazer trabalhar para ter o dinheiro para comprar a vestimenta, além de sugerir maior fiscalização dos contratos de trabalho.

Nessa nova estrutura social que tenta se impor, a força física/militar se sobrepõe ao saber ancião e a capacidade relacional de outras formas de existência. Força física para manter a organização das práticas, o controle dos corpos e do tempo para a produção que 
atende à metrópole, numa esfera funcional ao capital e, conforme Kurz (2008) se refere ao trabalho, cindida da vida.

Os dados da fiscalização nesse auge da colonização encontram-se hoje como material de consulta no Arquivo Histórico de Moçambique (AHM). É possível ler nestes documentos que a finalidade da fiscalização estava no controle das pessoas chamadas de indígenas ou trabalhadores "vulgar". Dessa forma, as pessoas caracterizadas como indígenas ou vulgar foram marcadas ao disciplinamento para o trabalho e colocadas em oposição aos trabalhadores tidos como especializados: europeus, homens brancos, ocidentais. Assim, podemos dizer que é bastante considerável o dispêndio de energia de europeus que trabalhavam na administração colonial, cuja função estava voltada para a elaboração de planilhas que registravam a contratação e saída desses trabalhadores chamados de vulgares, cujos salários eram registrados em tabelas, somados a relatórios dos acontecimentos e comportamentos dos trabalhadores do distrito, formando assim esse estado de vigilância e punição materializados numa grande quantidade de registros que dizem respeito, inclusive, à Companhia Carbonífera, que iremos falar no próximo item.

O historiador Coelho $(1989,23)$ aponta que em 1966 a Companhia Carbonífera era a única indústria nessa parte do território de domínio português. Esse mesmo autor, escreveu um romance intitulado Rainhas da Noite (2013), cuja história se passa em Moatize durante as atividades da Companhia.

O romance tem uma característica interessante que é ter dois narradores. Um deles é uma mulher branca, portuguesa, autora de um diário. O segundo narrador teria encontrado o diário e, como um pesquisador, tem o desejo de conferir a história que está nele registrada. Com isso esse segundo narrador apresenta seu processo de pesquisa para compreender a história pessoal dessa mulher e dos personagens de convivência dela, contextualizando em situações e nomes históricos do país africano, permitindo-nos ter um panorama da complexidade das relações dissociadas em Moatize naquele momento da colonização. Momento que, conforme estamos apresentando, era auge da imposição das relações para reprodução do capital.

No romance Rainhas da Noite, o historiador João Paulo Borges Coelho (2013) dános elementos das particularidades daquele momento, dá humanidade aos sujeitos que foram coagidos:

Ninguém gostava de cultivar algodão. O algodão não se comia, obrigava a muito esforço, vendia-se muito barato. Em suma, não compensava. O problema é que as autoridades precisavam muito de algodão, para alimentar uma fábrica de descaroçamento que haviam instalado em Moatize e por isso 
andavam sempre em cima das aldeias para garantir que ele era cultivado. Os sipais irrompiam pelas casas e pelos campos de cultivo querendo saber por que razão não se cultivava mais. Pressionavam os chefes. Muita gente foi presa por causa disso. (COELHO, 2013: 186)

No trecho que segue, o autor apresenta um entrave com uma situação de resistência frente à mobilização ao trabalho mostrando que esses sujeitos não estavam passivos diante da transformação em suas dinâmicas cotidianas, em suas práticas de reprodução. Havia inclusive resistência por parte dos régulos:

O régulo reunira a sua gente num grande círculo, no terreiro da aldeia. No meio do círculo colocara dois montinhos, um de algodão e outro de grãos de milho. Entre os montinhos largara uma galinha das suas, vulgar. Sem hesitações, a galinha aproximou-se dos grãos de milho e começou a debicá-los. E o régulo disse:

- Irmãos, se até a galinha, o mais estúpido dos animais, sabe distinguir o que é importante e se pode comer, porque haveríamos nós de pôr de lado o cultivo de milho para nos dedicarmos ao algodão? (COELHO, 2013: 198)

No romance, a consequência para o régulo por essa atitude foi que ele também foi preso e sofreu uma violenta agressão física que o deixou manco. E aqui vale dizer que, ainda que não saibamos a data exata que se passa o romance, compreendemos que seja entre 1948 e 1975, por ser no período de atividade da Companhia, mas antes da Libertação Nacional, quando foi fundada a República Popular de Moçambique.

Sabemos ainda que em 1941:

Com o fim de melhor controlar as várias fases do cultivo, os Governadores das províncias passaram a emitir ordens de serviço que permitiam às companhias concessionárias empregar capatazes na promoção do cultivo do algodão, nas respectivas áreas. Eles deveriam ficar formalmente sob o controlo dos sipaios dos administradores. A partir de então, pancada, torturas, abuso sexual e prisões arbitrárias feitas por sipaios e capatazes, tornaram-se métodos comuns para promover a produção de algodão nas machambas familiares (...). Não eram métodos novos, mas alargaram-se. (HEDGES, 1999: 92).

Ou seja, a violência que consta na ficção foi na realidade garantida juridicamente para o controle da população.

Os cipaios, que anteriormente comparamos à figura do capitão do mato no contexto brasileiro, além de cobrar impostos, punir e forçar ao trabalho, eram responsáveis pelo recenseamento e controlavam os fluxos migratórios na tentativa de 
evitar possíveis fugas que, de acordo com a bibliografia consultada, eram muitas. Além disso, forçavam o aprendizado da língua portuguesa.

Para os autores como HEDGES (1999: 88) e NEGRÃO (2006), esse momento particular de Moçambique era ofuscado no contexto internacional. Para eles o que ofuscava eram os absurdos cometidos associados à Segunda Guerra Mundial, pois outras tantas violações ocorriam ao mesmo tempo e assim a população moçambicana perdia visibilidade e apoio internacional. No entanto, vale lembrar que a invisibilidade do que ocorre no país africano se estende até os dias atuais dado o valor que é atribuído ao mundo branco e ocidental, em detrimento às vidas africanas ${ }^{37}$.

Essa situação registrada no romance Rainhas da Noite, além de expor uma relação da violência imediata, nos permite pensar nas transformações das relações com o tempo e sobre a figura do régulo, que é bastante emblemática. Quando o réguloo volta à cena após a prisão ele havia mudado de lado e passou a cumprir as ordens da administração estatal. Por isso, aqueles que conheciam o régulo diziam que mesmo fora da prisão ele não havia sido solto:

Continuou preso embora o inspector tivesse alongado a corda que prendia o pobre homem. Regressou às suas terras, mas era agora um homem diferente. Passou a pressionar a sua gente a plantar algodão, de que distribuía as sementes, além de informar os sipais de presença de gente de fora com hábitos suspeitos. Em suma, M'Boola [o régulo] era agora um homem atormentado pelo medo, e talvez pelo remorso da traição (COELHO, 2013: 218).

Então, retomando a ordem hierárquica do poder da administração local "tradicional", se o Nhakwawa recebia os poderes do Mambo (espírito do antepassado) e o Mfumo seguia as orientações de Nhakwawa, quem é o Mambo para o régulo? Qual é o feitiço que o régulo segue ou melhor, que ele deve seguir? Aqui voltamos para as formulações de Kurz (2010: 15) sobre a formação do fetichismo da mercadoria, pela perspectiva da sobreposição de uma forma totêmica pela forma do valor não consciente e escravizante das vidas e para propósito alheios. Esse é um ponto fundamental para compreender a crítica de Kurz, ao não ontologizar relações de fetiche do capital. Com base nas formulações desse autor é que compreendemos essa estratégia da colonização como um processo de substituição daquilo que é cultuado (o que é tido como feitiço) e das formas de dominação para a naturalização do culto do dinheiro e do trabalho.

\footnotetext{
${ }^{37}$ Recomendamos a leitura do livro intitulado Necropolítica, do filósofo camaronês Achille Mbembe.
} 
Conforme já mencionamos, no romance de Coelho (2013) um dos narradores realiza uma pesquisa para organizar e conferir a veracidade da história que foi narrada na forma de diário. Entre o processo de pesquisa está a pesquisa em documentos guardados no Arquivo Histórico de Moçambique. Um deles, e que aqui compartilhamos como possível de ser um documento oficial, dá luz à importância da cooptação dos régulos para a coerção ao trabalho:

Num Boletim de Informação com o n. ${ }^{\circ}$ 36, do mês de Novembro, o administrador do Zóbue ${ }^{38}$ afirmava: As populações estão revoltadas por se sentirem lesadas no mercado do algodão em Agosto último (...). Ainda por cima a maior parte das vezes não se faz distinção entre as duas classes de algodão (...). Pôde ser constatado que o caminho de acesso à sede da regedoria, bem difícil dado o acidentado da região, não sofrera as reparações que tradicionalmente foram e são da atribuição das populações, não obstante a recomendação desta autoridade. Situação similar à actual ocorreu no ano passado, em que o próprio regedor, quando se viu prestes a afundar-se por falta de autoridade e de prestígio, solicitou socorro deste Posto que, para lhe valer, lançou mão do feiticeiro de grande prestígio de nome Bissuasse Minjale, que à custa de poderes fictícios teria inculcado naquela autoridade meios para restabelecer certo equilíbrio ${ }^{39}$ nas soltas rédeas do mando tradicional (COELHO, 2013: 187-188 - itálico do autor, grifo nosso)

Seria possível dizer que o fetiche da mercadoria não estava formado e por isso a necessidade do uso de prestígios dos feiticeiros? Ou seja, o trabalho não é pela promessa do salário e da mercadoria que irá acessar. É o medo do feitiço.

De qualquer maneira, em processo, o algodão se tornou um dos principais produtos de exportação e no contexto da Segunda Guerra Mundial era uma mercadoria que estava valorizada no mercado internacional. Hedges (1999: 84) explica que a diminuição da produção de algodão nos países que anteriormente o cultivavam fez com que preço do algodão aumentasse no mercado internacional. E esse algodão cultivado em Moçambique era matéria prima para a indústria têxtil da metrópole, cujos proprietários dessas indústrias eram contrários à implantação de indústrias na colônia, de modo a evitar concorrência. Medidas protecionistas que garantiam parte das condições para os capitalistas na metrópole.

\footnotetext{
${ }^{38}$ Posto administrativo na fronteira entre Moçambique e Malawi, bastante próximo de Moatize.

${ }^{39}$ Ao leitor interessado, alertamos que esse é um trecho que retomaremos adiante quando falaremos sobre coerção ao trabalho no contexto atual.
} 
Um interlocutor de pesquisa em campo trabalhou na fábrica de descaroçamento em Moatize. Ele nasceu em Maputo, e se identifica como um machangana ${ }^{40}$. Com seus mais de 70 anos de idade acompanhou mudanças nas dinâmicas do lugar. Seu pai primeiramente migrou de Maputo para Beira e depois para Tete por causa da profissão que tinha: enfermeiro. Num período em que as funções que exigiam qualificação eram ocupadas pelos brancos, ser enfermeiro era uma das profissões possíveis e incentivadas para serem exercidas por negros, por isso compreendemos como uma profissão que de certa forma possibilitava ascensão social à alguns. Este Sr., filho de enfermeiro, estudou com os europeus e formou-se em contabilidade. Trabalhou no escritório da fábrica de descaroçamento e, para demonstrar os lugares que acessava e como fazia parte de uma minoria, mencionou que era um dos três únicos negros que tinha carro na altura. Diferentemente dele, a maioria dos trabalhadores da fábrica ganhava muito mal, sofria mesmo e era obrigada a trabalhar em troca do salário que era pago em escudo. Nesse período, os negros que trabalhavam e reclamavam dos salários podiam ser demitidos e a função substituída por um trabalhador forçado (chibalo) (HEDGES, 1999: 61). Este, por sua vez, podia estar nessa condição por não ter pagado impostos, não comprovar trabalho, ou mesmo por ter se "rebelado" ao reivindicar melhores condições de trabalho. Ou seja, reclamar da condição de trabalho poderia piorar sua situação e transformá-lo num trabalhador por chibalo.

De acordo com esse interlocutor, o proprietário da fábrica de descaroçamento era o português João Ferreira dos Santos e a bibliografia consultada revela que a empresa desse português iniciou a exploração no país em 1897, inicialmente na Ilha de Moçambique e depois expandiu para o interior. As atividades desenvolvidas estavam na área de agricultura, pecuária e navegação. ${ }^{41}$

O historiador Hedges (1999: 27) expõe que de início (antes do auge da colonização), as culturas forçadas eram produzidas em terras dos colonos, o que exigia investimentos e empréstimos. No entanto, os colonos tiveram problemas por causa da pluviosidade em plantações de algodão. Então, a burguesia metropolitana portuguesa lentamente alterou o sistema e deixou de investir nos colonos, pois eles apresentavam altos custos e tinha reduzida produtividade. A produção do algodão passou para as terras dos que eram explicitamente forçados a trabalhar para eles, aumentando o número de

\footnotetext{
${ }^{40}$ Etnia do sul de Moçambique

${ }^{41}$ Atualmente, constitui-se como um holding chamado Grupo JFS. O Grupo autodeclara que tem uma história que se confunde com a do próprio país pelo impacto socioeconômico causado em Moçambique.
} 
produtores e transferindo para eles os riscos da produção: mau tempo, falta de técnicas (HEDGES, 1999: 28). Com a revisão bibliográfica e relatos do período, entendemos que o algodoeiro de João Ferreira dos Santos reproduziu relações da segunda forma apresentada, ou seja, quando já eram os próprios moradores locais que assumiam os riscos. De acordo com um jornal moçambicano, a empresa do português João Ferreira dos Santos:

Dava dinheiro a todos os camponeses para comprarem os insumos, que ele vendia, lavrava a terra e dizia: o teu campo é este mas não vende a mais ninguém, isto é para eu comprar e daí tinham o arroz, a farinha e o caril garantido durante todo o ano porque sabiam que daquela machamba produziam algodão e era monocultura [...]. Acrescenta João José Uthui que é Conselheiro da organização não governamental Grupo Moçambicano da Dívida (JORNAL VERDADE 30/05/2016).

Esse processo criava uma renda diferencial entre os agricultores e a consequência é que as áreas em que o solo era menos fértil era onde havia mais pessoas que iam para o trabalho obrigatório (HEDGES, 1999: 97) por não pagarem os impostos (renda) e nesse caso, Tete está numa zona árida, quente, de solo pedregoso e pouca vegetação, com exceção das áreas de várzea.

Tanto nas Companhias quanto nas obras de construção da infraestrutura eram encaminhadas as pessoas que estavam na condição de trabalho explicitamente forçado. Havia um contrato de trabalho com duração de 6 meses por ano e depois essas pessoas consideradas pelos colonizadores como indígenas deveriam retornar para as aldeias, onde estava a família deles e onde as mulheres permaneciam nas machambas. Esse momento pode aparecer como "descanso", no entanto era maneira de manter a família no campo e a produção de alimentos que era a base da reprodução dessas pessoas. Isso significa que não era necessário o pagamento de salário que cumprisse a função da reprodução social de toda a família, sequer a reprodução completa do próprio trabalhador, pois ele mantinha a base de sua reprodução que eram as machambas, ou seja, o acesso à terra e o cultivo para própria alimentação e dessa maneira o que havia sido pago ao trabalhador na forma de salário retornava ao Estado na forma de pagamento de impostos.

Cahen (2015: 146) demonstra que a remuneração paga em troca do trabalho forçado era calculada em função do imposto indígena e não calculada em função do valor produzido pelo trabalhador ou do rendimento que o dono pretendia auferir. Então $a$ remuneração mensal devia ser o equivalente a 25-40\% do imposto a pagar, o que 
significa que era preciso trabalhar entre dois meses e meio e quatro meses só para pagar o imposto.

É nesse sentido, por não garantir a reprodução completa do trabalhador, que Cahen (2015: 141) argumenta que o trabalho era forçado e não assalariado. No entanto, o trabalho assalariado não é também forçado? Com base em Marx e Gaudemar, argumentamos que o processo de expropriação obscurece a relação pela reificação do trabalho.

O argumento de Cahen (2015) é que o trabalho (explicitamente) forçado não estava no sentido de proletarizar os indígenas, mas de torná-los subalternos, pois neste contexto colonial de capitalismo periférico, é mais rentável não proletarizar do que proletarizar e por isso a escolha não foi arcaica, mas a mais rentável. Ainda no argumento do autor, quando proletarizado, seria necessário pagar à esse trabalhador pelo custo de sua reprodução social e o salário teria de ser maior. Então, o mais rentável para o proprietário - e aqui compreendemos que ele está pensando pelo aumento da mais valia - está no sentido de manter o modo de produção doméstico, ou seja, das machambas, cuja atividade era exercida pelas mulheres. As mulheres estavam nas machambas e continuavam produzindo para a alimentação, enquanto os homens estavam no trabalho explicitamente forçado pelo Estado. Cahen (2015) diz que o trabalho forçado é uma das formas não capitalistas de dominação capitalista, no entanto, questionamos essa formulação, tendo em vista que a relação estava numa totalidade da reprodução do capitalismo industrial e financeiro. E em crise.

Ao tratar dessa última parte do período colonial, Bragança e First ${ }^{42}$ apresentaram que

O sector camponês não só cultivou a sua própria comida, trabalhou para as plantações e para as economias da África do Sul e da Rodésia, como ainda forneceu, ocasionalmente, cerca de 15 por cento do total da produção agrícola comercializada para consumo interno e exportação. Perante estes factos, como é evidente, desmorona-se de uma vez por todas o mito do campesinato africano tradicional de subsistência (BRAGANÇA \& FIRST, 1981: 6).

Aqui para tentarmos organizar a apresentação do problema, invertemos a análise e saímos do ponto de vista do capitalista e do maior lucro possível, para olharmos para os que estavam na posição de trabalhadores.

${ }^{42}$ Pesquisadores do Centro de Estudos Africanos da UEM. 
BRAGANÇA \& FIRST (1981: 5) expõem como a territorialização do capital estava em processo e em sua forma particular diferia da forma clássica que compreendemos a partir da Europa. Os autores formularam que ao contrário do processo de instauração do capitalismo na Europa, não se tratou de um campesinato expropriado de suas terras e transformado em trabalhadores livres, livres para venderem a sua força de trabalho ao capital.

Sendo assim, duas maneiras de coerção estão no processo. Primeiramente a Lei do Indigenato que proibia os povos originários de manter suas práticas que foram consideradas como vadiagem, por não serem reconhecidas como trabalho. Sendo assim, a Lei obrigava-os ao trabalho explicitamente forçado, conforme apresentamos. A outra maneira de coerção ao trabalho era pela cobrança de impostos. Assim se aplicava uma violência extra econômica sobre essas pessoas, ao elas serem capturadas pelos cipaios, baseada num sistema juridicamente legal.

Gaudemar (1977: 189) afirma que para a transformação de dinheiro em capital é preciso do trabalhador livre. O trabalhador livre se constitui num duplo sentido: o primeiro sentido chama de liberdade positiva, em que o sujeito dispõe à sua vontade da sua força de trabalho como uma mercadoria que lhe pertence. O segundo sentido chama de liberdade negativa, pois o sujeito não deve ter qualquer outra mercadoria para vender, apenas a força de trabalho. Voltando para os sujeitos que estamos analisando em Moçambique, compreendemos que a liberdade negativa é formada pela necessidade de vender a força de trabalho principalmente para o pagamento de impostos, ainda que tenham acesso à terra. A liberdade positiva está em aparecer como uma possível escolha do sujeito de seu lugar de trabalho, caso contrário é que será encaminhado ao chibalo.

O processo de territorialização do capital foi também o aumento da cobrança de imposto que refletiu na produção de alimentos para consumo próprio dos povos originários. O pesquisador Negrão (2006: 51) apresenta que o aumento de dias de trabalho necessários para pagar os tributos teria provocado gradualmente a escassez de tempo para produzir alimentos para autoconsumo. Cahen (2015: 141), na mesma linha argumenta que o trabalho forçado teria provocado o momento em que atingiu toda a população masculina indígena, destruindo também a vida das mulheres, privadas da força de trabalho masculina nas práticas reprodutivas no contexto familiar. Hedges (1999: 106) apresenta ainda que o camponês tinha que vender, cada vez mais, a sua produção de alimentos básicos, diminuindo assim as suas reservas e expõe o registro de um inspetor 
de Manica e Sofala que em 1944 afirmou que pode-se afoitamente afirmar que a população indígena, em regra, passa fome.

Tendo isso exposto, é possível compreender um processo que provocou a fome de moradores do distrito de Moatize e compreendemos assim que havia uma forte transformação nas formas de reprodução social dessas pessoas pela sobrecarga de funções: o trabalho explicitamente forçado na construção civil, no cultivo de matéria prima para os portugueses, como algodão ${ }^{43}$ e arroz, além das atividades de produção do alimento de consumo próprio. Essa é uma contradição do sistema que BRAGANÇA \& FIRST (1981) afirmaram que nunca foi resolvida: ao mesmo tempo em que os homens eram obrigados a trabalhar pelo que era chamado de chibalo, eram necessários à produção agrícola.

Tal processo demonstra primeiramente o avanço da desestruturação das relações de trabalho na agricultura familiar, num processo de expropriação. Mesmo tendo acesso à terra, tais pessoas estavam privadas do tempo de trabalho nela, ao ter que estar a maior parte do tempo no trabalho e nas culturas forçadas, por isso não conseguiam produzir para alimentação própria. Esse é um processo que provoca lentamente a necessidade do dinheiro para mediação social e realização de necessidades, não mais apenas para pagar impostos. Por isso, chegou momento em que o que restava da remuneração para essas pessoas não era suficiente, por ter aumentado a necessidade de dinheiro na mediação para alimentação e outras relações. Um exemplo recorrente é oferecido pela literatura que trata das prestações matrimoniais, o lobolo ${ }^{44}$, no sul de Moçambique que passaram a ser pagas em dinheiro, não mais por bois.

A necessidade do salário está formada. E além dos trabalhos dentro do próprio Moçambique, as migrações para os países fronteiriços aparece como opção. Newitt diz que já a partir de 1935, o salário pago pelo trabalho nas minas de carvão nos países vizinhos tornou-se essencial para algumas famílias comprarem os alimentos que já não podiam cultivar (Newitt, 1995: 433). Os homens passaram a migrar principalmente para Rodésia do $\mathrm{Sul}^{45}$ ou África do $\mathrm{Sul}^{48}$ para buscarem salários, em processos migratórios que

\footnotetext{
${ }^{43}$ A principal cultura forçada era o algodão, pois tratava-se de matéria prima agrícola necessária para a indústria têxtil em Portugal (BRAGANÇA \& FIRST, 1981: 6).

${ }^{44} \mathrm{Na}$ cerimônia de casamento, a família do homem oferece à família da mulher o lobolo.

${ }^{45} \mathrm{Em} 1934$ há um acordo entre os governos que firmam o recrutamento de 15.000 trabalhadores anualmente da Província de Tete para a Rodésia do Sul, recrutamento feito pela Rhodesian Native Labour Bureau (RNLB) para o trabalho sazonal nas minas da Rodésia do Sul (HEDGES, 1999: 40; NEWITT, 1995: 435). ${ }^{48} \mathrm{O}$ início da exportação de trabalhadores para a África do Sul é datada do início da segunda metade do século XIX e em 1897 foi estabelecido o primeiro acordo entre Portugal e o Transvaal. Transvaal era parte da área que atualmente reconhecemos como África do Sul e nessa parte estavam os maiores depósitos de
} 
eram controlados pelos Estados envolvidos, cujos governos mantinham acordos de imposto sobre a migração.

O número de migrantes era elevado, a ponto de que tenha chegado a circular em Moçambique mais moeda britânica (tanto da Rodésia do Sul quanto da África do Sul) do que a moeda portuguesa, pois os trabalhadores eram pagos em libras e não escudo naqueles países.

Um de meus interlocutores em Moatize relatou:

O meu tio foi pro Zimbábue, ficou lá muitos anos e até morreu lá. Ele saiu de Moatize, estava em Chipanga ${ }^{46}$ e foi em 1953. Foi pra lá, casou, teve filhos lá. Foi a pé, não é de carro não. É longe e era difícil. Era época do Ian Smith. Aqui tinha controle no mato, ia longe até a estrada a pé, dormia no mato, carregava alguma coisa para comer, até chegar lá. Dinheiro era difícil naquela altura. Ia até Harare. Muita gente sempre ia até lá, sempre a pé. Iam trabalhar nas minas, mas para sair de lá e voltar mais para cá era problema. Chegava aqui o governo perguntava: "você estava onde? 12 anos no Zimbábue a fazer o que? Aqui não há trabalho, continua lá. Você vai nos trazer bandidagem". Ficavam presos lá. (LIONEL, 2017)

A migração para a Rodésia do Sul e para a África do Sul era controlada pelo Estado colonial para que se cumprissem os acordos entre os países e fosse concretizada a entrada de dinheiro e pagamentos de impostos. Supomos que um migrante que ia à pé e não nos caminhões dos recrutadores era um migrante ilegal e por isso provavelmente não era taxado e não interessava ao Estado o regresso dessa pessoa.

O que compreendemos dessa exposição do sr. Lionel é que mesmo sem a coerção explícita ao trabalho, eles migravam para o pagamento dos impostos e os salários dos migrantes era pago em dinheiro que posteriormente circulava dentro do país pelo consumo de mercadorias, principalmente do comércio de portugueses e indianos. Essa era a maneira que outras pessoas que não trabalhavam em troca de salário dispusessem de dinheiro para consumir e reproduzir relação que já estavam mediadas pelo dinheiro, como o lobolo, por exemplo.

ouro e diamantes que foram base da fortuna de Cecil Rhodes. A empresa Witwatersrand Native Labor Association (WENELA) tinha o monopólio do processo de recrutamento dos trabalhadores mineiros, principalmente homens de origem do sul do Rio Save em Moçambique, ou seja, das Províncias de Maputo, Gaza e Inhambane. Com base em Ruth First, Newitt diz que o recrutamento era realizado a princípio em meio a festas promovidas pela WENELA, onde distribuíam sabão e sacos de sal como aliciantes (NEWITT, 1995: 432).

46 Bairro em que as pessoas que foram removidas e reassentadas pela Vale viviam antes dos reassentamentos. 
O fenômeno da migração evidenciava a fragilidade do Estado português que dependia de fontes de divisas externas. É nesse imbróglio que Newitt concluiu que o lucro real desta política colonial, no entanto, não residiu na colecta do imposto de palhota ${ }^{47}$, mas na mobilização de um vasto exército de mão-de-obra para uso interno e para trabalhar nas minas de ouro da África do Sul (NEWITT, 1995: 339). Ao mesmo tempo, lentamente transformou as relações de reprodução, parte de um processo que leva a formação de sujeitos monetarizados.

\subsection{A Companhia Carbonífera: "sim, havia trabalho!"}

No período pós Segunda Guerra Mundial empresas e Companhias que estavam em Moçambique foram nacionalizadas ou em parte compradas pelo Estado colonial português. Entre elas está Companhia Carbonífera de Moatize. Inês Domingos Miguel (2009) apresentou em sua dissertação de mestrado em estudos africanos, defendida na Universidade do Porto, o que chama de evolução do processo da Companhia no distrito de Moatize, no período entre 1950 e 1973. Ela aponta que as primeiras concessões para exploração mineira em Moatize datam de 1919 para uma empresa belga, a Societé Miniére et Géologique du Zambéze, cuja sede estava no Congo Belga. O argumento dela é que após a Segunda Guerra Mundial Portugal recebeu uma fração do Plano Marshall e com isso pôde investir em Moçambique. Para ela, parte dessa fração foi então aplicada na compra da Companhia Carbonífera (2009: 28) que passou, em 1947 - no período definido como auge do regime colonial - a pertencer a Portugal em 10\% do capital (HEDGES, 1999: 162) e o restante de capital belga ${ }^{48}$.

Nessa nova ordem mundial em que houve a mudança da hegemonia política da Inglaterra para os Estados Unidos da América, houve a abertura de um novo canal de empréstimos para Portugal que, conforme argumentamos anteriormente, vinha num processo de débito com a Inglaterra. No pós segunda guerra, com a criação do FMI e

\footnotetext{
${ }^{47}$ É como o mussoco, cobrado em gêneros.

${ }^{48}$ Nesse mesmo período: “A produção siderúrgica brasileira contou com a primeira intervenção estatal entre os anos de 1940 e 1950, quando foram montadas ao lado da então instalada Companhia Siderúrgica Belgo Mineira, a Companhia Ferro e Aço de Vitória (Cofavi), instalada em 1942, no Espírito Santo; a Companhia Siderúrgica Nacional (CSN), instalada em 1941 em Volta Redonda (RJ); a Aços Especiais Itabira (Acesita), instalada em 1951 em Minas Gerais sob controle do Banco do Brasil e a Companhia Siderúrgica Mannesmann, instalada em 1952 também em Minas Gerais, subsidiária da empresa alemã do mesmo nome" (Leite, 2010: 195). A autora aponta ainda, a importante participação do BNDE(S) na implantação do parque siderúrgico nacional.
} 
Banco Mundial, os EUA assumem nova posição nas relações de domínio pela capacidade de emprestar, acumular por juros e colocam em prática uma padronização da Pax Americana em que o dólar é a nova moeda de reserva e do comércio mundial, ao ser a única moeda convertível em ouro, o sistema Bretton Woods.

Esse é o período de maior migração de portugueses para Moçambique. Hedges (1999: 165) apontou que entre 1951 e 1969, ou seja, quando a Companhia Carbonífera estava nos seus primeiros anos de funcionamento em Moatize, foram mais de 13 mil migrantes portugueses para todo o Moçambique. Miguel (2009: 99) argumenta que a Companhia Carbonífera foi fator de atração de trabalhadores para Moatize, pois eles estariam buscando melhores condições de vida, por isso provocou um crescimento do espaço habitado, geração de empregos e receitas para os cofres do Estado. No entanto, ela não relaciona ao que provocava de forma particular a repulsão desses trabalhadores de Portugal.

De qualquer maneira, o trabalho era necessário a esses imigrantes e para que eles se mantivessem empregados, esses homens brancos seguiam as exigências do regime colonial, submetiam-se e reproduziam as estruturas de opressão, naquele período em que a taxa de desemprego entre os brancos aumentava, inclusive, em Moçambique. Temos que a migração para Moçambique por si não era garantia de trabalho, pois já havia concorrência e com isso esses homens brancos imigrantes submetiam-se às diretrizes do Estado fascista, num lugar em que não necessariamente gostariam de estar e dizemos isso a partir do romance Rainhas da Noite escrito pelo historiador moçambicano João Paulo Borges Coelho (2013).

O romance Rainhas da Noite se passa em Moatize e acreditamos que no início dos anos $1960^{49}$ e consideramos um registro das particularidades das relações entre brancos e negros, homens e mulheres, funcionários da alta hierarquia da Companhia e os mineiros. Não tomamos o romance como verdade, pois é uma ficção, mas uma ficção escrita por um historiador que tem pesquisa em Tete e por isso acreditamos que seja difícil desvincular essas duas posições. Para nós, o romance joga luz a possíveis relações que gostaríamos de explorar e que registra algumas situações e elementos que também me foi narrado oralmente em pesquisa de campo, permitindo questionar os limites dessa ficção.

\footnotetext{
${ }^{49}$ Em dado momento do romance, o narrador pesquisador diz que já tem 50 anos os acontecimentos que investiga e a publicação é de 2013.
} 
Trata-se de um livro com dois narradores. O primeiro é uma mulher branca, Maria Eugênia, que registra num diário o seu cotidiano em Moatize. O segundo narrador seria o próprio pesquisador que teria encontrado o diário dessa mulher e busca compreender aquilo que está ou não escrito no diário. A partir do diário esse narrador realiza uma pesquisa em arquivos e entrevista um senhor que teria sido funcionário de Maria Eugênia, o Sr. Travessa. Configurando assim materiais de registro primário, história oral e a interpretação/ seleção do autor nessa narrativa, um historiador que escreve ficção.

No romance há um lugar central de convívio do pessoal superior da Companhia Carbonífera que é a Casa Quinze. Ela é colocada como lugar central das relações (contraditórias) que se formam em torno da Companhia Carbonífera. Para o autor, tratase do centro da teia estendida sobre Moatize e de onde irradiavam nesse tempo todos os enredos, numa expressão que nos remete à ideia de tessitura de Raffestin (1993), pelas quais atores formam uma rede de poder para se apropriar de um espaço e formar um sistema territorial. Entendemos que pela narrativa que envolve a Casa Quinze podemos pensar pela ficção nos atores que operam no processo de territorialização do capital (HEIDEMANN et al., 2014) por meio da Companhia Carbonífera e consequentemente dar particularidade àqueles que escreveram o que é tido como a história oficial daquele período, registrada em papéis que hoje se acumulam nos arquivos do país e por isso são para alguns aqueles que mais se aproximam da verdade com que se chega ao espírito de uma época (COELHO, 2013: 25).

As relações de poder que se concentram e emanam da Casa Quinze definem ao menos em partes a organização dos atores dessa teia, dessa rede. Nela vive a família do diretor geral da Companhia que no romance de Coelho (2013) se chama Sr. Simon, sua esposa é Annemarie Simon e eles são belgas. Entre os superiores da Companhia que frequentam a casa está outro casal belga, o Sr. Clijsters, engenheiro da Companhia, e sua esposa Suzanne Clijsters. Esses são belgas e também apresentados como extravasados do Congo (COELHO, 2013: 98), marcando possivelmente um movimento migratório de técnicos que trabalharam na mineração no Congo e que se dirigem à Moçambique nesse processo de expansão da mineração naquela parte do continente africano. Por fim há o casal de portugueses Murilo e Maria Eugênia. Murilo engenheiro elétrico e Maria Eugênia que é a autora do diário e que expõe esses outros personagens.

Além dos engenheiros e administradores da Companhia com suas respectivas esposas europeias, nesse restrito mundo dos brancos há um enfermeiro, o Sr. Mascarenhas, que é de ascendência goesa e funcionário da Companhia. Há ainda um 
inspetor, Cunha, que constitui uma espécie de polícia política e representa o Estado. Ele controla, pune e prende aqueles que não seguem as regras do regime colonial e aparece em várias situações de humilhação aos negros e de controle do ir e vir pelo distrito, inclusive dos próprios brancos funcionários superiores da Companhia. É ele quem controla para que as mulheres brancas não socializem com os negros, pune negros que dão qualquer tipo de abertura para elas e também a elas quando dirigem-se a lugares que, do ponto de vista do Estado, não precisariam estar. Compreendemos essa relação a partir das formulações de Scholz (1996), escritora da revista Krisis e Exit!, com a crítica da sociedade em que as relações estão organizadas pela dominação patriarcal. Scholz (1996) formula que a dominação patriarcal baseia-se essencialmente na institucionalização e na internalização de normas sancionadas na coletividade que restringe a influência das mulheres a uma esfera que lhes é atribuída. No caso particular que estamos apresentando, a esfera de influência que é permitida a essas mulheres parece restringir-se à Casa Quinze e as outras casas que tem relação com ela, das outras famílias que compõem a elite da empresa.

Entre os empregados dessas casas sempre há um que é considerado como um espião e informante à Annemarie Simon, esposa do diretor da Companhia, daquilo que acontece na casa dos outros brancos. Na casa de Maria Eugênia e Murilo quem faz esse papel é o Sr. Travessa. Esses empregados legitimavam a presença de madame Simon no interior das casas de todos os funcionários superiores da Companhia. Coelho (2013), que é um homem, descreve que esse estado de vigilância é entendido por Maria Eugênia como de curiosidade da mulher do diretor geral, próximo ao desejo individual de fazer fofoca. No entanto, ao longo da própria narrativa, Maria Eugênia muitas vezes sente-se obrigada a comparecer em reuniões na Casa Quinze, sem ter maneira de mentir o motivo da não ida, ao mesmo tempo em que sua ausência poderia comprometer seu marido na Companhia. A condição para mantê-lo no emprego parece, portanto, revelar a essência dessa dominação.

Esses são os personagens do mundo dos brancos, quando pensada a dissociação pela perspectiva da raça. Desse mundo, os homens brancos são trabalhadores livres especializados na Companhia, os superiores na hierarquia da divisão do trabalho. Em Moçambique esse homem branco tem uma relação de poder que não necessariamente teria na Europa onde poderia estar na condição de desempregado, enquanto em Moçambique eles, esposas e filhos são a high society de Tete, uma classe média em ascensão. No seu aspecto positivo, a liberdade do trabalho tem essa característica de dar uma aparente 
possibilidade do trabalhador escolher o seu trabalho e o local onde exercê-lo. Quer dizer, a mobilidade do trabalho é o exercício dessa liberdade (GAUDEMAR, 1977: 190). Com isso compreendemos que a esses homens brancos era permitido trabalhar distantes do seu lugar de origem - Bélgica, Portugal, ou ainda outros países, uma característica do indivíduo moderno, subordinado à coerção silenciosa das relações econômicas (HEIDEMANN, 2004: 28).

Maria Eugênia apresenta o conflito da ordem patriarcal naquele lugar em que era preciso ser-se homem e branco para se ser alguém (COELHO, 2013: 173). Ela caracteriza esses homens brancos como aqueles que fazem afirmações diretas, muitas vezes grosseiras, convencidos de não haver força na terra capaz de os desafiar (COELHO, 2013: 52) e em outro momento percebe que seu marido, tanto quanto os outros homens brancos, vê o mundo dividido simplesmente entre os que pensam e decidem e aqueles que se movem sem tino, como os "zombies" e as mulheres (COELHO, 2013: 52), ou seja, negros e mulheres não tinham poder de tomar decisões. Esses homens brancos, enfeitiçados pelo trabalho, passavam o dia enfiados no escritório, e seguiam as ordens sem questionar, pelo medo de terem de regressar à Europa e perder os privilégios que tinham em Moçambique.

Em “O valor é o homem”, Roswitha Scholz (1996), formula que a ascensão do princípio masculino do trabalho abstrato como um tautológico fim em si mesmo traz como resultado o confinamento doméstico e a repressão da mulher na história ocidental. Essa história ocidental é narrada no romance mostrando a particularidade dessa relação patriarcal e como se reproduz em África ao expor as mulheres brancas em Moatize. Elas estavam limitadas ao restrito grupo de estrangeiros europeus, confinadas em casa enquanto seus maridos iam ao trabalho. Mais do que isso, o romance expõe um grande distanciamento que elas tinham dos demais moradores do distrito, pessoas negras a quem elas se referem como "os outros", "vultos" ou "zombies".

Ao menos parte das mulheres brancas personagens do romance demonstra o desejo de sair dessa bolha e se aproximar daquele mundo ao redor, ainda que nos pareça mais pelo desejo que elas tinham em romper com o tédio. No entanto, as situações que remetem essa aproximação eram repreendidas pelo Estado colonial como momentos de subversão, por isso resultavam em punições. A rotina dessas mulheres é registrada por Maria Eugênia em seu diário onde descreve o tédio em que se viam repetidamente jogando cartas (canastra) ou se ocupando com revistas e discos antigos da indústria cultural estadunidense ou europeia que os maridos compravam para elas quando iam para cidades 
como Salysburg (atual Harare - no Zimbábwe). Eles iam para Salysburg, no país de colonização britânica, para comprar peças para as máquinas da Companhia.

As mulheres brancas se percebiam numa relação de inutilidade, pois estavam supérfluas naquele mundo em que quem realizava inclusive os serviços domésticos eram os homens e, nesse caso, os homens negros. Um dos personagens do romance diz que nunca vira mulheres a servir nas casas dos brancos (COELHO, 2013: 37). As atividades domésticas eram realizadas por esses homens negros que eram: cozinheiros, jardineiros, guardas, ajudantes, dentre outras muitas funções. E havia ainda a função denominada de macaiaia que eram crianças negras que cuidavam das crianças brancas.

O tédio se torna um problema para essas mulheres brancas. Sem ocupação elas entram num estado de degradação, numa aparente depressão ou ainda histeria, que era uma questão da época. Mas para o Sr. Travessa, homem negro que trabalhava na casa de Maria Eugênia, o estado dessas mulheres era compreendido sob outra lógica, era resultado de um espírito que tomava os corpos delas, transmitindo o que anteriormente outra mulher que viveu no mesmo lugar também sentiu, pois para ele, além do mundo dos vivos, existe o mundo dos mortos, no mesmo lugar.

Nesse ambiente, Suzanne diz à Maria Eugênia que Moatize era lugar onde às mulheres era vedada a possibilidade de exercerem a sua função mais fundamental, precisamente a de serem mulheres. O que revela que quando viviam na Europa tinham rotina diferente por terem outra função social. Então Maria Eugênia se lembra das mulheres negras: marcando o compasso do dia com o matraquear dos pilóes sob os alpendres de palha, ou batendo a roupa nas pedras das margens do rio (COELHO, 2013: 71). Dito isso, notadamente é exposta a dissociação entre as mulheres brancas e negras.

O problema do confinamento era das mulheres brancas, não das mulheres negras, pois as mulheres negras faziam parte de uma sociedade agrária em que o divórcio entre esfera pública e privada ainda não se achava configurado ou apenas em pequeno grau (SCHOLZ, 1996). Assim, nos parece que essas mulheres que trabalhavam nas machambas poderiam ter um relativo poder de influência entre as relações sociais às quais estavam imersas ou ao menos estavam úteis nessas relações. O que, ainda baseado nas formulações de Scholz (1996), não significa que essas mulheres da sociedade agrária estivessem isentas de outras relações de opressão, mas o caráter da diferenciação pauta-se nesse momento da análise, sobretudo pela divisão entre a esfera pública e privada.

Angela Davis (2016: 232), referindo-se aos EUA, afirma que as mulheres negras escaparam, em grande medida, ao dano psicológico que o capitalismo industrial impôs 
às donas de casa brancas de classe média, cujas supostas virtudes eram a fraqueza feminina e a submissão de esposa. As formulações dessa autora permite-nos colocar num padrão essa dissociação entre mulheres brancas e negras e nos permite pensar sobre a construção da ideia de fragilidade associada às mulheres, mulheres brancas, o que não corresponde à ideia construída da mulher negra que não estava confinada e em oposição constrói-se a ideia de que sejam mulheres fortes que suportam o desgaste do trabalho.

À parte da diferenciação entre brancos e negros, voltemo-nos agora ao próprio mundo dos negros. Nele também há diferenciação por gênero, cuja perspectiva da dissociação notadamente foi imposta pelo regime colonial. Os homens foram os primeiros a serem mobilizados para a forma social que aparece como finalidade de trabalhar para os brancos. Além de realizar as atividades domésticas para os brancos, no romance esses homens negros aparecem ainda como trabalhadores mineiros e trabalhadores de obras pelo distrito. Uma das situações de encontro entre o mundo das brancas com o que acontecia ao redor, foi numa cena em que Maria Eugênia e Suzanne vão até uma aldeia e então, ao a primeira descrever o lugar, diz que não via homens naquela aldeia apenas mulheres e crianças, ou seja, os homens estavam no trabalho. No caminho de regresso para casa, já ao fim do dia, é que elas cruzam com grupos de mineiros que voltavam dos seus turnos em fila indiana, pela berma da estrada. Aos olhos dessa mulher branca, esses mineiros mal tinham o que comer (COELHO, 2013: 91; 39).

Conforme expusemos no item anterior dessa dissertação, a atividade da Companhia Carbonífera abrange o período em que os homens negros eram mobilizados de forma juridicamente forçada pela Lei do Indigenato. Um dos meus interlocutores e entre os mais velhos moradores do atual reassentamento Cateme, ao Sr. Arnaldo, com seus 65 anos de idade, narrou a particularidade do processo de recrutamento dos trabalhadores para a Companhia Carbonífera:

A Companhia buscava pessoas na Angônia, em Chiúta. Escolhia a gente e fazia contrato segundo o regime. Esses trabalhadores viviam no bairro Sete. Nos compounds [...]. No tempo da Companhia faziam isso. Levavam para trabalhar mesmo aqui, ou no Chimoio. No Chipanga não podiam ficar sem trabalhar. Se não houvesse lugar, levavam em outro sítio. Triagem, obras, armazém. Ia lá e começava a trabalhar. Para assimilar o trabalho é preciso habituar-se. No princípio é dor. Mas depois de 3, 4 meses automaticamente habituava-se ao serviço. (ARNALDO, 2017).

Tal relato narra a violência extra econômica que submetia os camponeses ao trabalho na Companhia. O bairro Sete, onde estava a moradia dos mineiros migrantes: o 
compound, contrastava do bairro Nove, que atualmente é popularmente chamado de CARBOMOC e onde está localizada a Casa Quinze, que aos olhos de uma moradora atual do bairro eram brancos que aí viviam. No bairro CARBOMOC estão essas casas, em aparente boas condições. São casas que guardam a antiga arquitetura que fez parte do rol de relações da Companhia Carbonífera em detrimento às casas do bairro onde viviam os negros, mineiros da Companhia Carbonífera, materializando a dissociação valor do período.

O historiador Cahen (2015: 149) argumenta que interessava aos portugueses que os indígenas fossem mantidos na forma em que os consideravam enquanto tal e não fossem considerados assimilados. Essa era maneira para que não estivessem no espaço urbano, nem competissem por trabalho com os brancos, pois isso era intolerável para sindicatos corporativistas de trabalhadores brancos. Por isso, ao manter os corpos negros cisionados da forma social, os limitaria às funções que lhes fossem atribuídas e os trabalhos com melhores condições e salários estavam garantidos aos brancos, mantendo privilégios e uma vida mais confortável. Abaixo transcrevemos a formulação de Cahen que apresenta a diferenciação entre os elementos que o colonizador atribuía aos indígenas e aos assimilados:

Se a definição de indígena só pode ser aplicada aos negros, a simples qualidade de negro não é suficiente, uma vez que certos negros podem ser não indígenas. A "raça negra" é definida pela cor da pele, mas essa raça não é suficiente para definir o indigenato. Tem que se definir uma "raça social": o indígena com certeza é negro (às vezes mestiço), mas é aquele cuja vida social é exterior à esfera capitalista. A cultura está presente na definição de quem pode sair do indigenato e se tornar assimilado (romper com os "usos e costumes", conhecer a língua portuguesa), mas o que é mais discriminante socialmente é a definição da natureza do trabalho, isto é, a desqualificação da esfera civilizacional de toda a atividade econômica africana considerada em bloco como um não-trabalho. Uma vez mergulhado no trabalho forçado, era dificílimo sair deste mundo de miséria porque o trabalho forçado não contribuía para o aprendizado da língua portuguesa para além das poucas palavras estritamente necessárias às relações de trabalho, não se podia obter um dinheirinho para comprar sapatos e, ainda menos, investir numa charrua de tração animal, etc. Qualquer ascensão social tornava-se impossível. (CAHEN, 2015: 151-152).

Percebemos que a cor da pele por si não era a razão da diferenciação, mas a dissociação valor é marcada pelo trabalho e reproduz estruturalmente uma relação de 
exclusão, pois o negro não tem maneira de se inserir na relação que supostamente os coloca como iguais e assim não competiam com os brancos.

Essa relação assimétrica é por nós estudada por Roswitha Scholz que argumenta que é uma relação que não é passível de ser explicada pelas ciências naturais, ou seja, não é ontológica e também não é cultural, mas um processo histórico que se formou nesses termos raciais, entre negros e brancos.

A abstração do trabalho é que coloca essas pessoas em igualdade e que, no caso das pessoas consideradas indígenas, tinham como uma fantasiosa possibilidade de competição pelo trabalho a partir do processo de assimilação. O historiador Cahen (2015) compreende essa prática como característica da colonização portuguesa, que diferente da colonização inglesa explicitamente racista, conforme podemos perceber pelo Apartheid sul-africano, no caso português há uma aparente política de integração pelo violento processo civilizatório ${ }^{50}$.

Essa questão se materializa num apartheid social (Krisis) ${ }^{51}$ e aqui utilizamos essa referência por considerarmos que há uma relação do valor e esse vem do trabalho para o que se configura na separação espacial que é lembrada em pesquisa de campo por diferentes moradores como um ressentimento do período de dominação colonial.

Então, retomamos o romance onde fica perceptível que durante o regime colonial a relação assimétrica entre as posições sociais passaram pelo trabalho em que determinadas funções eram restritas ao brancos ou aos negros assimilados, enquanto aos negros considerados indígenas, em processo de disciplinamento ao trabalho e de expropriação, estavam os trabalhos mais pesados e os trabalhos explicitamente forçados, num processo que foi legitimado com bases jurídicas:

No estatuto do indigenato de 1926 são considerados indígenas os indivíduos de raça negra ou dela descendentes que, pela sua ilustração e costumes, não se distingam do comum daquela raça [...]. Já no código de 1928 e 1929, quem não cumprir cumulativamente três condições - ruptura com os usos tradicionais da raça negra, falar português, exercer uma profissão etc, é indígena. (CAHEN, 2015: 145)

Nesse sentido, o negro considerado analfabeto não estava na mesma condição que os brancos analfabetos (CAHEN, 2015: 151), nem aos negros assimilados, ou seja, a lei se aplica ao negro, mas o negro que Cahen (2015: 151) diz estar fora da esfera capitalista. No entanto, questionamos essa formulação de Cahen, visto que na totalidade da relação o

\footnotetext{
${ }^{50}$ Nesse ponto, o autor lembra do modelo brasileiro freyriano, referindo-se ao mito da democracia racial.

${ }^{51}$ Aqui utilizamos o termo com base nas formulações do grupo Krisis no Manifesto contra o Trabalho.
} 
trabalho que os homens negros exercem está na esfera capitalista, pois participam do processo de reprodução.

Em processo, a dissociação valor foi se tornando mais severa e vale dizer que uma pessoa quando reconhecida como assimilada não tornava seus filhos também assimilados. Com isso, uma criança negra podia ser impedida de frequentar a escola do Estado, pois para elas haviam as escolas missionárias e essas crianças poderiam ainda ser recrutadas para o trabalho forçado. Lembramos as crianças negras que tinham como função no romance de Coelho (2013) cuidar das crianças brancas, função chamada de macaiaia.

Em pesquisa de campo, o interlocutor Sr. Arnaldo demonstrou que leva consigo muitas histórias que foram contadas pelos seus antepassados sobre o período de atividade da Companhia Carbonífera. Ele fala bem português, por isso durante a conversa não houve necessidade de tradutor. Ele nasceu em 1952 e diz que nessa altura o pai já trabalhava na Companhia, ou seja, poucos anos após o início das atividades da mineradora. Antes de trabalhar na Companhia o pai dele trabalhou na construção da linha de Sena dos Caminhos de Ferro de Moçambique (CFM). Essa sequência de trabalho: Caminhos de Ferro e depois Companhia Carbonífera foi frequentemente narrada pelos moradores dos reassentamentos da Vale. Eles viviam em Chipanga e Mithethe, mas provavelmente outros moradores do distrito de Moatize e talvez dos distritos ao redor também tenham passado por essa mesma mobilização de trabalho.

No romance de Coelho (2013) ao expor a história de um personagem, o narrador expõe o seu processo particular de mobilização ao trabalho: Lampião Chassafar foi transferido para a Societé Minière em Moatize, obrigaram-no a trocar o caminho-deferro pelas minas (COELHO, 2013: 327). Lembramos que a construção dos Caminhos de Ferro ocorreu no auge da colonização e no auge do trabalho forçado e ela conecta a vila de Moatize ao porto da cidade da Beira, uma ilusão de cordão umbilical que ligava a pequena vila ao resto do mundo (idem: 30$)$. 


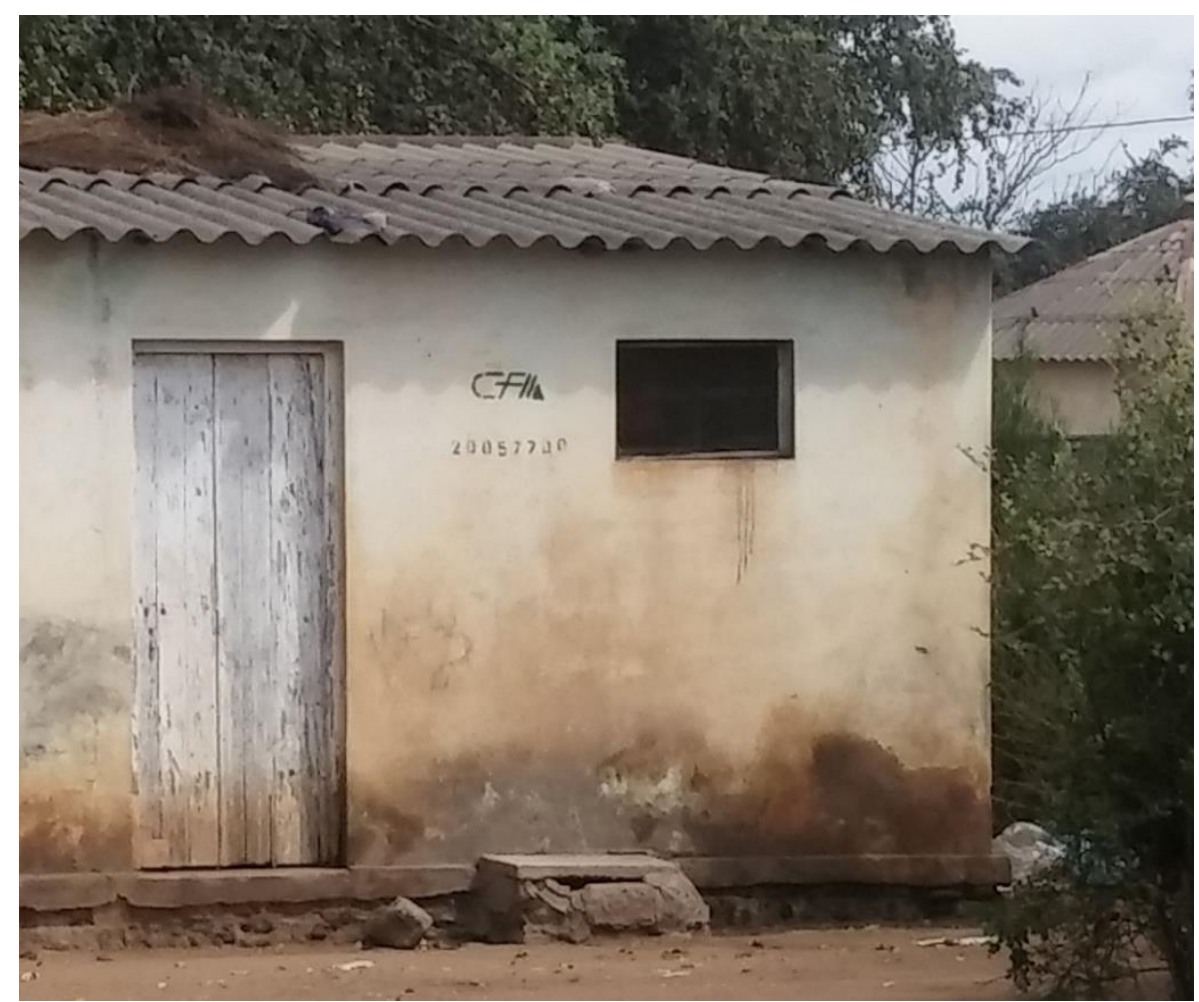

Figura 4: Casa que abrigou trabalhadores dos Caminhos de Ferro de Moçambique (CFM) localizada no bairro 6. Fonte: Viviane Alves Vieira - 2017

O Sr. Arnaldo trabalhou na Companhia Carbonífera e a função dele era despachante de carvão, além de ter sido praticante datilógrafo. Funções dentro da divisão do trabalho naquele contexto exercidas em escritório, não nas minas subterrâneas como a maioria dos trabalhadores da Companhia que nem sempre falavam português. Tal posição acreditamos que seja com a condição de uma mínima formação escolar naquele período, mas teria ele sido considerado um assimilado? Ele frisou bem que quando trabalhou na Companhia Carbonífera ele quem buscou por esse trabalho, por isso ele não reconhece esse como um trabalho forçado, ou seja, como chibalo, pois para ele não é explícito. Ao vender a força de trabalho, o Sr. Arnaldo tinha maneira de obter dinheiro para pagar os impostos e comprar mercadorias que se tornaram necessárias ou acessíveis com a condição do dinheiro. Assim, o que pode parecer de forma "voluntária", a violência permanece na relação, ainda que de outras formas. A violência do trabalho está obscurecida na relação e com isso ele diz em tom de obviedade que precisava de trabalho, de salário para viver, já desconsiderando o processo que o levou a necessitar do trabalho. Ele apresentou que naquela altura era bastante fácil ter trabalho: bastava chegar e dizer que queria trabalho, não era forçado. E assim ele o define, pois o processo já é contado de forma naturalizada. Ele trabalhou na Companhia Carbonífera entre 1970 e 1977, um período de transição que abrange o final do período colonial, o governo de transição e 
após a Libertação Nacional (1975). Narrou que não permaneceu na CARBOMOC após a nacionalização da Companhia Carbonífera, por questões políticas.

O Sr. Arnaldo trabalhou na Companhia já no fim do período colonialista e as relações de trabalho poderiam diferir do período em que a Companhia iniciou as atividades no distrito. Cahen (2015), por exemplo, considera os anos 1950 como período de declínio do trabalho forçado. Ele formula que o trabalho forçado era alvo de críticas internacionais e embasavam argumentos daqueles que defendiam a descolonização, o que não era de interesse da metrópole e faz com que esse declínio possa ser justificado como resultado de acordos internacionais que formulavam o que veio a ser convencionado como direitos individuais e as leis trabalhistas. A juridificação do trabalho obscurece a relação ao legitimá-la e positivá-la e a relação deixa de ser explicitamente forçada. Ao mesmo tempo, a intensificação do processo de expropriação intensificava a necessidade de venda da força de trabalho.

O que queremos dizer é que o que aparece como declínio do trabalho forçado é parte do próprio processo de abstração do trabalho assalariado, pois conforme apresentamos no item anterior, o aumento dos impostos diminuiu a produção de alimentos, provocando maior necessidade do dinheiro e consequentemente pessoas mobilizadas ao trabalho, obscurecendo a relação de obrigatoriedade ao trabalho. O que faz com que não haja a necessidade do sistema do chibalo para a coerção de pessoas ao trabalho pela obrigação explícita.

Durante o regime colonial, a mínima formação escolar era uma imposição, pois era parte do processo de disciplinamento para o trabalho. Hedges (1999) ao levantar os elementos do que constituiu o processo colonial e ao demonstrar o lento caminho da formação da força de trabalho para a produção que era para o regime, coloca a escola como o que dava coesão ao processo de assimilação.

A política de assimilação, mesmo no sentido restrito, de levar a população, através da educação, a participar numa cultura europeia e a gozar os direitos de cidadania do império português, não deixou de ser uma mera justificação teórica para a presença colonial, cuja estrutura de dominação racial, na prática, impediu tal acesso. A discriminação racial, no sistema de educação, no regime jurídico e de propriedade, na legislação e nas práticas laborais, no código comercial e, fundamentalmente, no acesso aos direitos políticos, mostra a hipocrisia da ideologia colonial de assimilação. (HEDGES, 1999: 182). 
Seria o Sr. Arnaldo parte de uma minoria negra que não estava nas minas? Podemos colocá-lo como parte de uma minoria negra que passou por um processo de mobilização ao trabalho com uma formação escolar, tal qual o interlocutor mencionado anteriormente, filho do enfermeiro e que trabalhou na fábrica de descaroçamento?

Hedges (1999) traz ainda o papel da Igreja Católica como principal responsável por aquilo que podemos colocar como educação, ao ser ela quem alfabetizava durante o regime. Ensino praticado em língua portuguesa. Isso significa que a educação foi instrumento do Estado mediada pela Igreja.

O Sr. Arnaldo tem ainda bons conhecimentos do processo de extração do carvão e números exigidos pelo regime colonial: "Tínhamos de fazer produção diária, eram 3 minas. Por isso tinha que ter efetivo para atender a situação da Companhia". Essa exposição demonstra que a compreensão dele era de um trabalho que estava realizando para a empresa, para outros, com uma meta diária. Ele explica a importância de ter estoque, o tipo de carvão de preferência do atual Malaui e da África do Sul, por exemplo, países que estavam entre os compradores do carvão. Além disso, lembra fielmente os horários de trabalho: "1" turno: das $6 \mathrm{~h}$ às $14 \mathrm{~h}$, segundo turno das $14 \mathrm{~h}$ às $22 \mathrm{~h}$ e terceiro turno das $22 h$ às $6 h$ ". Trabalho realizado de segunda a sexta, 8 horas diárias com possibilidade de realizar horas extras. Então, esse trabalhador que estava no escritório tinha uma relação de trabalhador assalariado, com horários regulares a ser cumprido.

Acreditamos que nessa altura já tinham atravessado o processo de disciplinamento para o trabalho e por isso não cabem ao que Coelho (2013) ilustra no romance Rainhas da Noite, ao narrar a função das sirenes para marcar o tempo do trabalho, visto que os mineiros desconheciam haver outras formas de medir o tempo. Relógios, por exemplo (COELHO, 2013: 39). O Sr. Arnaldo segue dizendo que o trabalho tinha meta e um salário em troca, além de alimentação:

Tinha alimentação que o trabalhador recebia: 700 gramas de farinha por dia, 290 gramas de arroz. Havia pessoas que recebiam semanal e havia quem recebia diário. Havia pessoas que trocavam em dinheiro, mas dependia do custo do salário. A pessoa que ganhava pouco não era como a que ganhava mais, as despesas eram diferentes. (ARNALDO, 2017).

Outro morador do reassentamento 25 de setembro complementou em outra conversa. Com um português apressado, mas dispensável de tradução, disse que havia refeição no local que ele chama de lavagem: 1 copo de leite e 1 pão. Esse senhor entrou na Companhia Carbonífera em 1968 e trabalhou como eletricista dentro das minas, não 
no escritório. Ele disse que para ir trabalhar havia uma pessoa que ia até a casa dele buscalo e depois o levava de volta à casa, todos os dias.

Excluindo o processo de formação e olhando para o trabalho em si, por essa perspectiva de comparação entre o presente e o passado que viveram, podemos dizer que meus interlocutores reconheceram que o trabalho na Companhia Carbonífera não era fácil, principalmente ao comparar com o contexto atual da mineração. Naquela altura, a extração do carvão pela Companhia Carbonífera se dava com menos tecnologia e de forma subterrânea, não a céu aberto como atualmente, carvão extraído do subsolo de Moatize, inclusive do subsolo dos bairros Chipanga e Mithethe.

Trabalhar nas minas subterrâneas era um constrangimento que envolvia passar horas com pouca luminosidade, alta temperatura, grande desgaste físico. Por isso, com a exploração atual que é céu aberto, por mais impactante que seja e nas mais variadas formas, lentamente está degradando as práticas sociais e a própria saúde dos moradores do distrito, conforme eles próprios denunciam, a exploração atual é compreendida pelos meus interlocutores como mais segura. Muitos moradores do distrito repetem lembranças de inundações com a elevação do nível do lençol freático em período das cheias dos rios, sem que os mineiros tivessem maneira de sair. Ou explosões nas minas, sejam acidentais por explosão de grisu ${ }^{52}$, seja no cenário da Luta de Libertação, como represália do regime colonial ao movimento de libertação que avançava, conforme moradores dos reassentamentos relataram.

No romance Rainhas da Noite, Maria Eugênia registrou em seu diário o que o marido Murilo contou sobre um acidente nas minas:

Tinha havido um acidente numa das galerias, uma explosão, uma secção inteira ruíra, cinco ou seis mineiros haviam morrido, outros tantos estavam desaparecidos, o lugar ainda estava cheio de equipas de socorro, as picaretas abriam caminho o mais rápido que podiam, os capatazes por dever de ofício e os mineiros com a motivação particular da camaradagem, a pressa de procurarem dentro do chão os seus irmãos (...). Alguns membros partidos mas sobretudo pulmões relutantes em funcionar, cheios de fuligem de gases e das mil e uma substâncias que pululam pelas galerias da mina. Entretanto viera mais gente das outras galerias, gente do compound, e era já muita, concentrada e murmurando, parece que protestava mas ainda não era claro o que pretendia, e chegara também a polícia, os sipaios do Administrador, os homens de

\footnotetext{
${ }^{52}$ Gás inflamável liberado durante a exploração em minas de carvão e que quando numa concentração acima do que era considerado seguro, uma faísca poderia provocar a explosão.
} 
inspector, todos tomando posição em volta. (COELHO, 2013: 156 - grifo nosso).

Esse trecho é momento em que as diferentes camadas da sociedade estão em cena, uns vítimas do acidente, outros técnicos que sentem-se responsáveis em resolver a questão. No romance, Maria Eugênia, surpreende-se em como a notícia espalha-se rapidamente entre os moradores de Moatize e entre os tantos que trabalhavam na casa dela. Assim como alguns mineiros, alguns desses trabalhadores das casas viviam no compound, que eram as moradias coletivas para os trabalhadores da Carbonífera, por terem origem em outros distritos ou povoados:

Em baixo do alpendre, os criados encolhiam-se com os olhos em brasa, também eles cheios de medo. E eu fiquei a perguntar-me como teria chegado a notícia até eles se Murilo falara tão baixo, e concluí que era muitas possibilidades, muitos os canais, o motorista Laissone, por exemplo, nas suas idas e vindas entre a casa e a mina, os camionistas que passavam a todo o momento como se trouxessem notícias embrulhadas como as mercadorias, os polícias e enfermeiros que ao fim do dia despiam fardas, batas e uniformes e eram gente como a outra que ia dormir ao compound ou aos muitos bairros em volta, lá onde também dormiam os criados, e as pessoas conversavam, comiam, preocupavam-se, e afinal era esta a sua vida. (COELHO, 2013: 157).

O elevado número de mortos em tais tragédias faz com que muitas das famílias de Moatize tenham antepassados que morreram nessas condições e, entre eles, numa das explosões, estava o pai do Sr. Arnaldo. O pai dele morreu na explosão das minas Chipanga VI, em 1976, explosão que matou 98 pessoas. Um ano depois, houve uma nova explosão: as minas Chipanga III. Nessa explosão morreram 64 trabalhadores das minas subterrâneas. Essas explosões se deram após a Libertação.

Uma reportagem de 2011, ao lembrar o episódio, diz que escassos foram os corpos retirados das galerias, pelas condições que estas ficaram, mas que parte foram enterrados no cemitério do bairro 25 de setembro (bastante próximo do reassentamento 25 de setembro) e outros tantos foram levados para Angônia ${ }^{53}$ por serem de pessoas naturais daquele distrito, o que nos leva a pensar que eram moradores do compounds. A reportagem diz ainda que os mineiros são moçambicanos e negros. A hierarquia, pelo

\footnotetext{
53 Aparentemente o recrutamento de trabalhadores em Angônia foi durante todo o período de funcionamento da Companhia, visto que em trabalho de campo foi nos relatado o recrutamento forçado de trabalhadores naquele distrito para Moatize já por volta de 1914, ano em que iniciaram as atividades da Sena Sugar Estates. No entanto, Newitt (1999), apresenta outro elemento: em determinadas épocas, muitos indígenas migravam para evitar o recrutamento obrigatório para o serviço militar e aí devemos considerar que a data apresentada pelos meus interlocutores é também no período da Primeira Guerra Mundial.
} 
contrário, é formada por estrangeiros (portugueses e belgas) e brancos (CASTANHEIRA, 2011: 45-46), de acordo com o enredo do romance e evidencia a dissociação que aparece pela raça.

A reportagem de Castanheira (2011) sobre a explosão de 1977 joga luz ao momento conflituoso em que ocorreu o episódio ao primeiramente apresentar as questões que foram colocadas sobre a culpa pelas explosões. $\mathrm{O}$ argumento conduz como um acidente e expõe situações de risco a que os mineiros estavam submetidos como, por exemplo, o que foi visualizado entre os dias da explosão em que um professor italiano, ao visitar as minas a convite do então presidente moçambicano Samora Machel, vê:

Um eletricista de canivete em punho a descarnar um fio elétrico. A simples fricção do metal, ao gerar uma quase inevitável faísca, seria suscetível, se caso houvesse uma concentração de grisu - o gás que coabita em todas as minas de carvão, resultante de mistura de metano e oxigênio - de detonar uma terrível explosão. Isso não é para fazer cá em baixo, essas operações fazem lá fora - protestam exaltados os acadêmicos. (CASTANHEIRA, 2011: 42).

Teria o autor da reportagem considerado que o próprio conhecimento dos riscos pode ser por si restrito aos brancos acadêmicos, relações estruturalmente excludentes?

No entanto, diante do ocorrido, Castanheira diz que a posição da Frente de Libertação de Moçambique (FRELIMO), que é o partido político que assumiu após a Libertação, e das principais mídias de Maputo, assim como o que foi dito por meus interlocutores em pesquisa de campo, é que tratou-se de sabotagem. As explosões teriam sido intencionais, visto que os portugueses colonialistas não aceitaram a Libertação e por isso provocavam os acidentes para fechar as minas, numa espécie de boicote ao novo governo que estava se formando e assumindo a condução do país.

Nesse argumento o boicote ao governo socialista moçambicano poderia vir ainda do apartheid sulafricano, do regime branco da Rodésia do Sul ou ainda da Resistência Nacional de Moçambique (RENAMO) ${ }^{54}$ (CASTANHEIRA, 2011: 57), movimento que fazia oposição ao partido FRELIMO. Esses são os dois grupos que estiveram em guerra civil iniciada naquele mesmo ano, 1977.

\footnotetext{
${ }^{54}$ A RENAMO foi um movimento político anticomunista que se formou com apoio da África do Sul e da Rodésia, países alinhados ao império estadunidense, por isso é historicamente oposição à FRELIMO que tem origem marxista e em sua origem teve apoio dos países alinhados ao império da União Soviética, naquele momento de bipolaridade na expansão das relações de produção de mercadorias. A RENAMO passou a ser um partido político apenas em 1992, com o Acordo de Paz. Foi quando Moçambique deixou de ser uma país monopartidário. No entanto, desde a Libertação é a FRELIMO quem está na liderança do governo, ainda que tenham eleições a cada 5 anos.
} 
O relato na reportagem joga luz ao momento conflituoso ao descrever a reação dos moradores do distrito diante do acidente:

O eng. Sousa Pontes disse-me, muito preocupado, excitado mesmo: "Houve uma explosão na mina e o pessoal está todo à minha volta. Venha por ordem nisto. Estão a arrombar o escritório com picaretas". Devo ter sido a última pessoa com quem ele falou e imagino que já deviam estar muito perto de o agredir. "Ponha ordem nisto!" - foram as últimas palavras que lhe ouvi. Virado para a janela, telefone encostado ao ouvido, Henrique Sousa Pontes é atingido por um bloco de cimento e cai redondo no chão. Morto. Com Sousa Pontes morrem mais oito europeus, incluindo todos os engenheiros. (CASTANHEIRA, 2011: 46)

Henrique Sousa Pontes era português. Chegou em Moçambique em 1964, após trabalhar 10 anos em Angola. A data de sua chegada coincide com o ano do início da Luta Armada contra o regime colonial, liderada pela FRELIMO. Quando ocorreu a explosão, em 1977, Moçambique já era Independente (1975). Pontes era o diretor geral da Companhia Carbonífera, por isso ele e sua família eram os moradores da Casa Quinze. Casa que, de acordo com a reportagem de Castanheira (2011), teria se tornado para moradores de Moatize uma casa mal assombrada e o espírito de Sousa Pontes estaria a vagar pelo distrito.

Se por um lado a explosão da mina é uma questão que se coloca na dúvida entre acidente ou explosão criminosa, por outro lado a reportagem meandra pelo que teria alimentado aquilo que sucedeu e classifica como massacre. Então, para os portugueses, a questão que se coloca é no desejo de compreender se a reação que levou a morte de 9 homens brancos e de nível mais elevado na hierarquia empresarial teria sido como uma convulsão social ou foi orquestrada.

Esses homens brancos que morreram no massacre eram engenheiros, chefes mineiros e o diretor geral da Companhia que naquela dissociação eram os funcionários que formavam a elite da Companhia e diante da complexidade em ter um culpado pelo ocorrido, Castanheira (2011) relatou em uma revista portuguesa, uma situação ocorrida dias depois do massacre e durante um comício da FRELIMO presidido por Marcelino dos Santos (um dos porta-vozes do governo FRELIMO). Ao questionar quem havia matado a direção da mineradora, "dois mil braços se levantaram e a totalidade dos participantes gritou: fomos nós!”.

Entre meus interlocutores há a memória de que pessoas foram presas:

Mataram com picareta, morreu muita gente. Aí foram parar na cadeia, mas o que resolveu? Aquela gente já morreu. Não é assim? Vai pra cadeia, 
depois da cadeia cumpre. O mais sentimental que aconteceu com aquela gente é que não receberam nenhum dinheiro. Porque as pessoas que podiam fazer a documentação, eles mataram. Então onde vão buscar dinheiro? Se quem tem a assinatura do banco, quem tem conhecimento são aquelas pessoas que conhecem o trabalho. (ARNALDO, 2017)

Chamamos atenção para o que esse interlocutor coloca como sentimental, não é nem a morte dos brancos portugueses, nem a prisão dos trabalhadores considerados culpados, que da mesma forma daqueles que morreram nas explosões, trabalhavam em condições consideradas degradantes. Para ele, o que é sentimental é por não ter resultado em acesso à dinheiro que é o maior problema apresentado no contexto atual.

Não nos cabe julgar o ocorrido. O que apresentamos é que as interpretações do conflito que envolve a morte dos superiores da Companhia conforme exposto, se colocam hoje divididas por questões que podem ser classificadas como de classe e raça, pois Sousa Pontes e os outros que morreram no motim personificam uma classe e uma raça. Esse dia é narrado pela história oral, por exemplo, como o dia em que expulsaram os brancos, não necessariamente se referindo aos que morreram no motim (até porque, de acordo com Castanheira (2011), há quem acredite que eles estão a vagar pelo distrito), mas aos sobreviventes que, por medo de também serem mortos, regressaram à Europa após passarem alguns dias exilados na casa do Governador, em Tete. Além de serem brancos, eles eram também a classe dos administradores da Companhia e por isso trabalhadores que não desciam às minas nem corriam os riscos como os mineiros.

No entanto, o que meus interlocutores e ex-mineiros contestam atualmente a partir da experiência pessoal em relação ao trabalho é que naquele período havia exploração por serem pagos com baixo salário, mas argumentam que, mesmo com o que hoje compreendem que era um baixo salário, o trabalho dava possibilidade de sobrevivência, coisa que na conjuntura atual não ocorre, pois atualmente não há trabalho.

\subsection{CARBOMOC: Libertação e o trabalho no socialismo}

Na passagem do sistema colonial para o Estado Nacional, após a Libertação de Moçambique (1975), a exploração de carvão em Moatize continuou no planejamento estatal, naquele que foi o governo socialista no país. A Companhia Carbonífera foi nacionalizada em 1978, passando a se chamar Empresa Nacional de Carvão de Moçambique, a CARBOMOC, numa estratégia alinhada ao marxismo leninismo. Um de meus interlocutores explicou: mudaram depois que veio o "país FRELIMO", o que nos 
parece uma forma de expressar que a organização das relações continuou sob o comando de líderes que lhes pareciam externos.

Numa publicação de 1985, ou seja, 10 anos após a Libertação, o escritor Moreira escreveu aos Cadernos do Terceiro Mundo sobre o primeiro presidente moçambicano Samora Machel:

O presidente sonhava, então, com um Moçambique pacífico, convivendo respeitosamente com todos os povos do mundo, inclusive os portugueses, abrigando uma nova sociedade, progressista e sem opressores nem oprimidos (MOREIRA, 1985:28).

Os Cadernos do Terceiro Mundo circularam durante o período da Guerra Fria com publicações dos países então considerados do Terceiro Mundo. Eram reportagens críticas ao imperialismo que sintetizavam as ideias que circulavam entre os países e a crítica comum entre os correspondentes que escreviam para a revista. Por esse fragmento é possível perceber que a perspectiva da revolução socialista é compreendida por Moreira como uma transformação na relação de classe ao contrapor opressores e oprimidos.

Moçambique tinha suas particularidades naquele momento histórico. Moreira escreveu um ano antes do assassinato do ex-presidente moçambicano, Samora Machel. Era momento em que o país atravessava uma sangrenta guerra. Um conflito entre o governo moçambicano representado pela FRELIMO, na altura um partido único, e uma agressão externa que foi inflamada principalmente pela Rodésia do Sul e África do Sul, e internamente esteve representado pelo movimento guerrilheiro da RENAMO, que mais tarde veio a se constituir enquanto partido político. Esse conflito durou 16 anos (19761992).

De acordo com o sociólogo brasileiro Costa, durante o regime colonial em Moçambique já havia no país um pensamento crítico e contestatório. Ele exemplifica com o Lutar por Moçambique de Eduardo Mondlane que foi escrito sob perspectiva anticolonial. Para ele, as ciências sociais nasceram em Moçambique com o movimento de libertação nacional e as guerras anticoloniais ao ser a partir disso que quebrou $o$ monopólio de casta sobre o conhecimento e da hegemonia ideológica colonialista (COSTA, 2015: 22). O pesquisador coloca a Luta da Libertação (1964-1975) como um ponto de partida para as Ciências Sociais moçambicana propriamente dita.

O historiador moçambicano João Paulo Borges Coelho (2015), por sua vez, também coloca a Luta Armada como um divisor de águas na historiografia moçambicana, ao ser um momento decisivo que define o passado de Moçambique. No entanto, o autor formula que o orgulho da luta contra o colonizador substituiu o trauma que foi a guerra e, 
para ele, esse foi um dos instrumentos para a revolução porque foi maneira de construir uma unidade moçambicana, no desejo de formar a identidade nacional (COELHO, 2015: 155). Por isso, para Coelho (2015) foi de fato uma revolução política e social e considera que não foi uma mera substituição de elites políticas.

A elite política que estava em formação inclui a formação intelectual que que daria base às ciências sociais. Costa (2015) formula que foi a partir da Libertação que os teóricos teriam passado a criticar marxistas no sentido de buscar incluir nas análises as realidades periféricas e assim, no artigo citado, o autor expõe seus estudos sobre a socióloga e militante do Partido Comunista da África do Sul Ruth First além de expor como foi formado o Centro de Estudos Africanos (CEA) da Universidade Eduardo Mondlane, fundado em 1976, e a sua importância naquele período ${ }^{55}$.

O primeiro diretor do CEA foi o jornalista marxista Aquino de Bragança. Ele foi uma das pessoas que estava numa sala na Universidade quando, em 1982, Ruth First recebeu uma carta enviada pelo regime do Apartheid: uma carta bomba. Esse episódio é tido como um golpe contra Moçambique e ao Movimento de Libertação na África do $\mathrm{Sul}^{56}$. Como o próprio Bragança declara, ele e Ruth First estavam envolvidos com os movimentos de libertação de África e escreviam sobre as lutas anti-imperialistas e os movimentos de lutas progressistas (Bragança \& Laughlin, 1996). Ele por sua vez, era assessor do presidente Samora Machel, ou seja, jornalista e militante que trabalhava para o Estado moçambicano em construção. Em 1986 eles estavam juntos no avião que foi derrubado e provocou a morte de ambos (JORNAL NOTÍCIAS, 2013).

Quando era diretor do CEA, em 1977, Bragança convidou Ruth First a retornar para Moçambique após o período de prisão na África do Sul e de exílio em Londres. Ela então lecionou o Curso de Sociologia do Desenvolvimento onde discutia suas bandeiras de luta, cujo cerne era o processo de socialização da produção em Moçambique com as machambas estatais e cooperativas. Eram estratégias compreendidas como forma de romper com a relação de dependência regional (BRAGANÇA \& LAUGHLIN,

\footnotetext{
${ }^{55}$ Os Estudos Moçambicanos que temos como referência bibliográfica em diferentes momentos nessa dissertação são publicações do CEA. Na primeira edição da revista, o editorial assume "como princípio a rejeição da divisão do trabalho na produção do conhecimento característico da burguesia, e o departamentalismo e carreirismo acadêmico, bem como o isolamento profissional que aquela divisão de trabalho gera" (FIRST, 1980, 2), marcando a relação entre teoria e prática como princípio do CEA e a perspectiva do que vinha a ser o pesquisador naquele momento para o país e no socialismo.

56 No Museu do Apartheid, em Johannesburg, há um vídeo que mostra o julgamento daqueles que enviaram a carta à ela. No entanto, não foram punidos dada a política de Reconciliação.
} 
1996:114115), resultado das migrações de trabalhadores para o país sul-africano, conforme apresentamos anteriormente.

O curso que Ruth First lecionou era voltado para estudantes e trabalhadores das variadas partes do país, para compor aquele que era o quadro revolucionário. Bragança \& Laughlin apontam 4 pilares que sustentaram esse curso: 1. formação teórica do método marxista para análise pautado na luta de classes; 2 . implementação da teoria apreendida na prática do trabalho diário, a práxis política; 3. construir o socialismo e nova organização de produção numa luta posta contra a estrutura do subdesenvolvimento e que tinha como ponto central de crítica a mais valia e que aparece como "mão de obra barata", por isso o objetivo era construir "uma classe trabalhadora disciplinada, permanente, consciente e bem paga" (BRAGANÇA \& LAUGHLIN, 1996: 121); 4. A transformação em Moçambique seria a libertação da África do Sul, ou seja, os moçambicanos representavam a luta contra o Apartheid ao romper com essa economia regional de sistema de desenvolvimento desigual.

Foi nessa perspectiva que Ruth First liderou os estudos sobre as migrações de mineiros moçambicanos para a África do Sul, que resultou no livro O mineiro moçambicano: um estudo sobre a exportação de mão de obra em Inhambane, publicado pelo CEA em $1977^{57}$. A principal reflexão do livro está em registrar a história da opressão e exploração durante o período colonial e que teria gerado o subdesenvolvimento da economia nacional (CEA, 1998: 1). A perspectiva de análise está em torno da dependência de Moçambique em relação à África do Sul, dependência que compreendemos pela entrada de divisas ao Estado pela exportação de trabalhadores para trabalharem na mineração e pelo dinheiro cuja origem era o salário desses mineiros que então circulava em Moçambique. O interesse de First, de acordo com o autor, e que concordamos a partir da leitura d'O mineiro moçambicano, era orientar propósitos para a reconstrução nacional e a transição socialista.

Eram mobilizados para o trabalho na África do Sul principalmente homens cuja origem era do sul do Rio Save, ou seja, não abrangia o centro de Moçambique onde está Tete. No entanto, sabemos que durante o período colonial havia fluxo de trabalhadores principalmente para a Rodésia do Sul (atual Zimbábue) e que o regime colonial tentou por diversos acordos com o regime colonial britânico a mesma relação com a África do Sul: regularizar a entrada de divisas para o Estado via pagamento de tributos, o que

\footnotetext{
57 Além desse, há O ouro negro, que Diogo (2015:27) também coloca como clássico nos estudos de Moçambique pelas conclusões teóricas e por integrar campos distintos de conhecimento nas análises.
} 
internamente também poderia constituir entrada de dinheiro para o comércio via consumo. A diferença entre esses dois fluxos migratórios foi apontada por Issufo Adamo, Robert Davies e Judith Head (1981) ${ }^{58}$ por primeiramente aqueles que migravam para a África do Sul serem recrutados legalmente pela empresa chamada WENELA, enquanto os que iam para a Rodésia do Sul iam em sua maior parte de forma clandestina. Isso significa que esses homens não eram contabilizados para a arrecadação dos tributos que eram acordados entre os países. O segundo ponto da diferenciação é que os trabalhadores do centro de Moçambique, ou seja, onde está Tete, saíam de áreas de plantação de monoculturas, a Sena Sugar Estates, por exemplo, onde o trabalho era explicitamente forçado e tinha salários baixos e as condições de trabalho eram péssimas.

No anexo I podemos conferir que Tete estava no meio do caminho para que os trabalhadores de Angônia (onde ficava a Sena Sugar Estates) chegassem à Rodésia do Sul. Como o Estado não controlava toda a área que lhe era tida como jurisdição, haviam as rotas de fuga do trabalho forçado. O argumento de Issufo Adamo, Robert Davies e Judith Head (1981) é que a partir dos anos 1960 os meios de produção no setor agrícola e mineiro na Rodésia do Sul se modernizaram e diminuiu a necessidade de trabalhadores de Moçambique. Então, quando se dá a Libertação de Moçambique, esse fluxo migratório oficialmente já estava bem restrito. Mas não podemos dizer o mesmo em relação ao sul com a migração para a África do Sul.

A questão dessa mobilização de trabalhadores para a África do Sul foi compreendida por um momento pelos pesquisadores do CEA como um problema para a transição para o socialismo, pois a exportação de pessoas para trabalharem nas minas na África do Sul era parte da formação e crescimento de uma relação definida como de trabalhadores-camponeses ou ainda semiproletário, por serem trabalhos sazonais. Para First, o migrante estava integrado num esquema de penetração da economia monetária no período em que as formações sociais moçambicanas se subordinavam aos objetivos da expansão do capitalismo (CEA, 1998: 3). O estudo demonstra que a entrada de dinheiro pelos mineiros provocava uma diferenciação entre os agricultores de Moçambique baseado em duas premissas: era com o salário dos migrantes que compravam bens de consumos (dinheiro disputado nos comércios indianos e portugueses na altura colonial) e era com o salário dos migrantes que as famílias camponesas moçambicanas investiam na agricultura. Ou seja, os próprios moçambicanos mesmo com

\footnotetext{
${ }^{58}$ Pesquisadores do CEA
} 
atividades agrícolas já dependiam desses salários. Nesse sentido, ao ter a base reprodutiva camponesa alterada pelo regime colonial ${ }^{59}$, esses agricultores foram forçados a procurar o assalariamento e, após oito décadas nessa dinâmica de trabalho sazonal, o sistema migratório tornou-se uma necessidade estrutural.

A Teoria da Dependência dava base às formulações da socióloga, enfrentava o imperialismo com o nacionalismo, que era a perspectiva revolucionária na altura. Costa (2015) oferece um panorama do período e argumenta que essa era a sociologia que floresceu nos países em transição ao socialismo, praticada em países como Rússia e Polônia, uma sociologia descritiva e funcionalista para planos econômicos e objetivos políticos (COSTA, 2015: 24) que compreendemos como um instrumento para o planejamento estatal. Nessa perspectiva, naqueles primeiros anos após a Libertação, Ruth First argumentou que a FRELIMO tinha como objetivo político terminar com esse sistema de trabalho migratório (CEA, 1998: 2) e diante da relação estrutural de entrada de dinheiro em Moçambique, os estudos sobre os mineiros tinham a finalidade de planejar e apontar maneira de reintegrá-los ao setor agrícola e utilizar a experiência desses trabalhadores mineiros nos setores industriais, de transporte e mineiro no próprio Moçambique (CEA, 1998: 3). Ou seja, ainda que houvesse o desejo de desestruturar a molibização de trabalhadores para o país vizinho, o objetivo estava em realocá-los para o setor agrícola, industrial e de mineração para a modernização nacional. Newitt (1995: 431) diz que nessa altura, as mineradoras sul-africanas inclusive ficaram alarmadas, pois dependiam do recrutamento dos trabalhadores moçambicanos mal remunerados e por isso importantes no setor produtivo naquele país cisionado com o Apartheid.

Na edição de fevereiro de 1979 dos Cadernos do Terceiro Mundo, dois anos após a publicação do estudo sobre os mineiros, há a publicação de um diálogo entre Samora Machel e os mineiros que regressavam da África do Sul para Moçambique a fim de visitar familiares, o que acontecia num término de contrato, por exemplo. A notícia aponta que durante a visita ao país de origem, os mineiros entregaram dinheiro para o pagamento de um imposto cuja finalidade é dada como de reconstrução nacional. De acordo com o líder dos mineiros, o pagamento ocorreu ainda que houvesse pessoas que foram para a África do Sul há muito tempo, alguns antes mesmo de nascer (no ventre da mãe) (Cadernos do Terceiro Mundo, 1979: 98). Os mineiros foram ainda incentivados pelo presidente Samora a manterem a relação de trabalho migratório e envio de dinheiro para as famílias

\footnotetext{
${ }^{59}$ Acreditamos que já expusemos nesse capítulo anteriormente como a reprodução dos camponeses foi desestruturada durante o regime colonial.
} 
como um dever de patriotas, contrapondo-se assim ao objetivo inicial de interromper o fluxo migratório. Nesse sentido, o trabalho é também um dever de patriota e aqui lembramos que Kurz (1993: 23) formula que o socialismo transformou o trabalho abstrato numa religião, da riqueza nacional endeusada, transcendendo dos fins vinculados às necessidades humanas.

Tal fato demonstra que o Estado nacional moçambicano continuou cobrando o pagamento de impostos dos mineiros, pois era pelas vias sulafricana e por essa relação que era possível a entrada de dinheiro para o país. Como dissemos a origem desses homens era principalmente do sul de Moçambique mobilizados para a mineração no país sulafricano. E Tete?

Primeiramente consideramos o argumento de CEA (1998) ao dizer que já havia uma necessidade estrutural por parte dos moçambicanos em relação ao salário, que no caso da pesquisa sobre o sul do país, a origem do salário era a mineração na África do Sul. Em Tete podemos pensar numa relação com a própria Companhia Carbonífera, ou ainda a fábrica de descaroçamento de algodão. No entanto, mesmo com a dependência do dinheiro nas relações internas entre os familiares desses migrantes, outras formas de coerção ao trabalho mantiveram-se durante a República Popular de Moçambique, como pagamento de imposto como um dever de patriota que citamos anteriormente.

Voltemos à pesquisa de campo para pensar nas particularidades em Moatize no período socialista. Um de meus interlocutores narrou:

No tempo do Samora Machel que houve aquela Operação Produção em Niassa. Entre 1982... 1984. Muita gente foi para lá, em Chipanga saíram alguns... Muitos. Porque aquela campanha ali era para desempregado e ladrão, prostituta. Então, aquela era a campanha. Samora não queria isso. Não queria ladrão, não queria uma mulher é... pros-ti-tu-i-ção! Metia pra Niassa, vai roubar lá com os leões. Abriram uma nova cidade, chamada Unango. É um distrito. (SR. JOSÉ, 2017).

O livro Poder do Poder: operação produção e a invenção dos "improdutivos" urbanos no Moçambique socialista, 1983-1988, de Carlos Quembo (2017) ajuda-nos a compreender o que foi a Operação Produção que é a política a que o Sr. José se refere. Quembo (2017: 9) explica a operação como um programa do governo para expulsar coercitivamente os desempregados das grandes cidades e enviá-los para remotas zonas rurais onde - pelo menos teoricamente - iriam cultivar, naquele momento de crise para o estado moçambicano e que a FRELIMO justificou a operação em nome da legalidade revolucionária, da ideologia do "Homem Novo", da proteção dos ganhos da revolução, 
da necessidade de dinamizar a produção, para a recuperação econômica dum Estado pós-colonial em crise e para combater o crime (QUEMBO, 2017: 61).

A partir do relato de meu interlocutor e da publicação de Quembo (2017), podemos constatar que a relação de obrigatoriedade ao trabalho aparece, tanto quanto no período colonial, como medida contra a vadiagem, e essas pessoas são apresentadas pelos meus interlocutores e pelo próprio pesquisador como pessoas desempregadas, não camponeses necessariamente. Destacamos ainda, o período socialista como momento de mobilização de mulheres, coisa que até então não havia aparecido nos relatos e registros. A mobilização de mulheres para o trabalho aparece como medida contra ou para evitar a prostituição. Um interlocutor narrou em pesquisa de campo particularidades dessa mobilização:

Em Unango existiam mulheres com 30 anos que não conheceu homem. Aquilo ali foi preciso publicar na rádio. Está a ver? Tiravam fotografia das mulheres e mandavam para todo o país. Aquele que é solteiro: se-le-cionava, gostei dessa. Lá tinha mulheres! Tá a ver? Transporte, avião, tudo era do Estado. Levava o homem, chegava e falava assim: é esta aqui. Pronto. Venha com ela e vive aqui. Unango? Era problema sério! Existe aqueles que foram pra operação produção no tempo do Samora Machel, alguns homens não voltaram e ficaram de vez lá. Não voltaram. Aquilo ali transformou-se em vila e distrito. Então não quiseram mais voltar para Tete. (SR. JOSÉ, 2017)

Unango está localizado no distrito de Sanga, na Província de Niassa. Lá foi destino de muitos moçambicanos dentro da campanha agrícola da Operação Produção. No entanto, dificilmente a forma descrita pelo meu interlocutor em relação a essa situação das mulheres tenha ocorrido, dada as condições estruturais no país durante o período em que ocorreu a Operação Produção. Mas está no imaginário de meu interlocutor como método de gestão populacional pelo Estado.

Então, fica-nos a dúvida da relação da prostituição ${ }^{60}$ como fenômeno que já acontecia e era resultado de crise em que o trabalho já estava autonomizado e com isso a prostituição era maneira de acessar dinheiro sem ser necessariamente uma relação de imposição, mas como de necessidade pela própria relação de dependência do dinheiro na mediação de coisas e práticas. Ou se era uma classificação tanto como foi a vadiagem, nesse caso para as mulheres que não comprovassem trabalho e dessa forma era maneira de mobilização. Uma publicação do jornal macua apresenta que na altura do anúncio da

\footnotetext{
${ }^{60}$ Entre meus interlocutores, quando conversamos sobre o período colonial e da Companhia Carbonífera, a prostituição apareceu apenas em relação às mulheres brancas.
} 
Operação Produção, o então ministro da Administração Interna, Armando Guebuza, que veio a se tornar presidente da república, estimou que existiam 75 mil prostitutas só na capital, no entanto, de acordo com a reportagem, esse número presumivelmente contemplava mulheres que viviam sozinhas e mães solteiras ${ }^{61}$.

De qualquer maneira, as formas coercitivas ao trabalho estão postas e com base nas formulações de Heidemann qualquer tentativa de modernizar tardiamente traz consigo mais processos de mobilização forçada (HEIDEMANN, 2004: 36). A Operação Produção ocorreu enquanto o país atravessava uma guerra. As pessoas eram recrutados por Grupos Dinamizadores e polícias para trabalhar na agricultura em Niassa, conforme Quembo (2017) argumenta, nas campanhas de produção. Essas cooperativas agrícolas, também chamadas de aldeamentos comunais ${ }^{62}$, eram formadas pelo governo da FRELIMO para aumentar e melhorar a produtividade, numa política progressista ${ }^{63}$.

Para Costa (2015), Ruth First era contra o trabalho explicitamente forçado coletivamente nessas cooperativas agrícolas. A ideia de First era que as aspirações individuais dos camponeses e trabalhadores deveriam ser consideradas para que a agricultura pudesse apoiar e sustentar a industrialização. Ou seja, ainda que sem o trabalho forçado, o desejo da industrialização, de modernização era latente.

O jornalista Moreira, que referenciamos no início do item em que falava do progressismo de Samora Machel, apresentou naquele período socialista que:

Moçambique é um país com riquezas naturais e muitas carências. A exploração do carvão de Moatize pode ser um fator de desenvolvimento muito poderoso que fortalecerá a balança comercial, hoje apoiada na exportação da castanha de caju. A pesca é outra imensa riqueza. "É o nosso petróleo", nos dizia o presidente Samora Machel. Marcelino dos Santos, então ministro do Planejamento, nos falava com entusiasmo da exploração madeireira e da transformação do seu país num celeiro da África. (MOREIRA, 1985: 28)

Assim, o trabalho na mineração em Moatize permaneceu no período socialista. No entanto, a organização da sociedade para o trabalho e produção das mercadorias não estava mais sob determinações do Estado português e sim sob o Estado moçambicano que entre as ações, organizou uma escola de capatazes de minas de Moatize onde são

\footnotetext{
${ }^{61}$ https://macua.blogs.com/moambique para todos/2013/09/as-feridas-abertas-pelo-processo-dereeduca\%C3\%A7\%C3\%A3o-em-mo\%C3\%A7ambique.html

62 Sobre as cooperativas agrícolas em Moçambique, ver Casal, Adolfo Yañez: Antropologia e desenvolvimento: as aldeias comunais de Moçambique (1996).

${ }^{63}$ Mbembe (2001: 192) critica esse momento de libertação de países africanos em que os nacionalismos africanos substituíram o conceito de "civilização" utilizado pelos colonialistas, pelo de "progresso", sem uma reflexão propriamente filosófica sobre a condição africana.
} 
admitidos elementos com 21 anos de idade e com a mínima habilitação da $6^{a}$ classe (CENTRO DE DOCUMENTAÇÃO ECONÔMICA, 1977: 2).

Numa crítica um tanto ácida, Coelho (2015) pontua que tal instrumento nacionalista da FRELIMO durante o período socialista forneceu base para a legitimidade das políticas governamentais, nas decisões que eram tomadas pelos que ele chama de protagonistas da luta (COELHO, 2015: 155), se referindo à Luta da Libertação. Ao mesmo tempo, de acordo com o autor, tal nacionalismo tornou ilegítimo qualquer contestação política. É a partir disso, e pelos que estiveram na luta, que ele argumenta que a memória política se estruturou (COELHO, 2015: 156). Essa memória que ele considera triunfalista, construiu a memória política que é controlada pelas autoridades e estruturada em torno da luta de libertação e com isso tentam fazer dela uma memória coletiva. Quem mantém essa memória? Para o historiador, são os próprios ex combatentes. No entanto, ao retomarmos Ruth First e aos téoricos da formação no período, tomamos a causa desses combatentes como coletiva que se apresentava como o desejo da construção de uma nova sociedade progressista. A crítica estava ao colonialismo e ao desenvolvimento desigual.

Nas particularidades das relações, a crítica que se colocava estava no estado de humilhação e violência direta durante o regime colonial pela diferenciação entre raças, pelas camadas que se sobrepunham naquela sociedade estratificada. Nesse sentido, retomamos o item anterior e ao cenário da explosão das minas, em que para ser justo com os moçambicanos de Moatize após a explosão das minas, a estratégia do governo FRELIMO foi ouvir os mineiros e a partir deles eliminar quem os insultava, humilhava, ou seja, construir com eles:

O que pensam do José Maria? "Sim! Sim!” - disseram em uníssono e vibrantes. E fulano de tal? "Não! Não!" Porquê? "Só nos insulta e trata mal”. Então está decidido: este não regressa à mina! Sem votações e num clima de grande efervescência, os portugueses são analisados um a um. A reunião termina com os mineiros a cantar e a dançar (CASTANHEIRA, 2011: 54).

Castanheira (2011) aponta o desfecho para o conflito que desencadeou o motim de Moçambique: em uma reunião na escola primária de Moatize entre trabalhadores moçambicanos e o diretor nacional de Geologia e Minas, os portugueses foram analisados individualmente pelos seus comportamentos racistas, representando uma espécie de personificação da opressão em que, com a eliminação desses, a relação de dominação também seria.

Os portugueses que retornam à Portugal foram substituídos por trabalhadores da Romênia e técnicos da ex-República Democrática Alemã, países que foram parceiros 
daquele Moçambique socialista. Assim, no período socialista, os brancos também trabalhavam como mineiros, transformando naquela particularidade a relação de dissociação pela raça e a mercadoria força de trabalho estabelece a relação de igualdade entre pessoas. Um antigo mineiro disse durante a pesquisa de campo: na CARBOMOC o próprio alemão branco entrava na mina, saía preto como um preto. O branco estava a trabalhar com o preto. Além disso, mulheres também podiam trabalhar na mineradora.

A produção da CARBOMOC, por sua vez, era parte consumida internamente em fábricas de cimento, açúcar, nos caminhos de ferro; parte era exportada para Madagascar, Japão $^{64}$, África do Sul, República Democrática da Coreia e Romênia (CDE, 1977: 1). Para aumentar a produção de carvão mineral, as pesquisas do período já apontavam o desejo de modernizar os meios de produção. Um dos membros da atual associação CAPEMI contou que as minas a céu aberto começaram por volta dos anos 1980 - período da terceira revolução industrial - e a primeira empresa que usou essa técnica foi uma alemã-soviética, quando o presidente era Samora Machel. De acordo com ele, a empresa chamava Mijova Company e ficava no bairro Nhacolo. No entanto, nos arquivos consultados, encontrei apenas uma menção da exploração a céu aberto que teria ocorrido entre 1980 e 1982 cuja atividade foi interrompida por questões de segurança ${ }^{67}$. (SECH, 1984). Nesse documento, são relatados ainda estudos de viabilidade para a expansão da produção, com a necessária ampliação de infraestrutura e minas, estudos que estavam em processo de licitação e para a execução disputavam o Brasil, Argélia, RDA URSS e os financiamentos eram da parte da Itália, Kwait e da Organização dos Países Exportadores de Petróleo (OPEP).

Um ponto chave da crítica de Robert Kurz (1993: 29) ao socialismo é que, de acordo com ele, o socialismo não eliminou as categorias fundamentais do capitalismo: salário, preço e lucro e quanto ao princípio básico do trabalho abstrato, levou-o ao extremo. No caso de Moçambique, podemos dizer que de fato a relação com o trabalho abstrato foi mantida e impulsionada, no desejo da formação do Estado Nacional moçambicano, independente. Assim, a contradição do processo de modernização em si foi escamoteada por questões específicas do período no país africano.

\footnotetext{
${ }^{64}$ O Japão era tido como grande consumidor, pois naquela altura com a alta do petróleo, o país asiático buscava outras fontes energéticas. O Japão mantinha exploração de carvão no próprio país, pela Mitsui Mining (atualmente acionista da Vale S/A), no entanto, de acordo com os registros de Moçambique, a exploração não era o suficiente para as necessidades que tinham naquele momento (CDE, 1977: 10). 67 Vale lembrar que o país estava em guerra civil.
} 
O próprio colapso do socialismo em Moçambique se entrelaça com elementos particulares que teriam impossibilitado a continuidade das atividades produtivas, inclusive a agricultura, pois a guerra interrompeu redes, fluxos e a circulação de pessoas e mercadorias. Em Tete, aos poucos as atividades na CARBOMOC foram se encerrando. Em 1986 deixaram de circular comboios na linha de Sena que era a linha que ligava Moatize ao porto da Beira. Um de meus interlocutores que era pedreiro e construía casas para a CARBOMOC contou que deixou de trabalhar na empresa em 1987 por não ter mais trabalho para ele, pois não havia construção de mais poços de água, nem havia necessidade de manutenção das casas dos trabalhadores. A extração do carvão em si encerrou oficialmente em 1993, um ano após o Acordo de Paz assinado em Roma e o suposto fim da guerra em Moçambique. Era momento em que, com a crise do socialismo, Moçambique abria-se para o capital estrangeiro.

Oficialmente a mineradora CARBOMOC foi considerada extinta somente em 2006, um ano antes de ser assinado o contrato com a mineradora Vale. Inicia-se então um novo momento da mineração no país. Os trabalhadores que tinham vínculo com a empresa CARBOMOC quando se deu o fim das atividades, receberam indenização em 2007 e aqueles que contando esse período completaram o tempo de trabalho foram aposentados (MAUVILO, 2007). Pois bem, foi pelos relatos desses senhores aposentados que passamos a considerar importante retomar o que foi apresentado nesse capítulo por dar particularidades ao processo. Retomaremos esses interlocutores principalmente no último capítulo dessa dissertação.

\section{Capítulo 2: Reflexões em torno do acesso à terra}

\subsection{A Lei de Terras de Moçambique}

A Lei de Terras de Moçambique foi formulada no III Congresso da FRELIMO, em 1977, dois anos após a Libertação do país. Esse Congresso é considerado como o mais importante entre os congressos realizados pelo ainda atual partido político no governo, pois nele foram tomadas decisões que definiram as bases naquela que era a revolução socialista de Moçambique ${ }^{65}$. Foi nesse congresso que o movimento tornou-se um Partido

\footnotetext{
${ }^{65}$ No I Congresso da FRELIMO, em 1962, foi confirmada a luta do Movimento: Frente de Libertação de Moçambique (FRELIMO) cujo inimigo era o colonialismo português. A luta armada que se iniciaria em
} 
de Vanguarda Marxista-Leninista (DARCH, 1981) e nele foi organizado o processo de planificação centralizada com a nacionalização de empresas e também da terra. Em Moçambique a terá pertence ao Estado.

Em que difere quando a terra pertence ao Estado de quando a terra é privatizada? Vejamos. A Lei de Terras de Moçambique tem suas particularidades e foi apresentada pelo economista moçambicano Negrão (2000) como resultado de uma ruptura epistemológica na prática jurídica e inédita no país ao incorporar as práticas costumeiras (também denominada de direito consuetudinário) no direito formal estatuário. Para o autor, no período colonial essas duas lógicas de relação com a terra, costumeira e estatuária, são marcadamente distintas como se de dois países se tratasse.

Para evidenciar como o direito costumeiro não era aceito no período colonial, Negrão (2000) cita um trecho de um parecer do arcebispo D. Teodósio Gouveia negando um possível Estatuto do Direito Privado dos Indígenas. Nesse parecer de 1946, o arcebispo argumenta que codificar os usos e costumes bárbaros da raça negra em Moçambique é abraçar a civilização primitiva em lugar de se cumprir o propósito do Estado de elevar a moral dos nativos através das missões católicas (NEGRÃO, 2000: 3). Um argumento iluminista do arcebispo que, numa compreensão dualista da relação, coloca em oposição o sistema costumeiro ao processo civilizatório que ele impulsiona, colocando assim o primeiro modelo como atraso. Nessa perspectiva dualista, para existir um sistema deve haver o apagamento de outro e, nesse caso, o apagamento das práticas costumeira. Para isso, conforme já vimos no primeiro capítulo, há muita violência direta, disciplinamento e coerção.

A Lei de Terras é por isso apresentada por Negrão como inédita ao contemplar as práticas costumeiras reconhecidas pelos sistema de Direito de Uso e Aproveitamento da Terra (DUAT) e portanto, a lei abrangeria a multiplicidade do que constitui a organização social moçambicana. Negrão (2000: 3) sintetiza que:

O direito de uso e aproveitamento da terra é adquirido por: ocupação por pessoas singulares e pelas comunidades locais, segundo as normas e práticas costumeiras no que não contrariem a constituição; A comprovação do direito de uso e aproveitamento da terra pode ser feito por prova testemunhal apresentada por membros, homens e mulheres, das comunidades locais (grifo nosso).

1964 foi definida como forma de alcançar a independência. No II Congresso em 1968 se deu a consolidação da linha revolucionária anti-racista e anti-tribalista. (DARCH, 1981). 
Trata-se assim de um momento em que a oralidade é acatada e não apenas registros escritos e Negrão (2000) considera esse fato como importante na inovação da Lei. Ele argumenta que a lei foi construída com base em discussão entre vários setores da sociedade, no que abrange os aparelhos ideológicos do Estado, com pesquisadores de diferentes especialidades e com pesquisa de campo em todo o país. Dessa maneira parece contemplar mais pessoas, facilitar a comunicação e considera a autoridade local, ou seja, que não faz parte do que constitui o Estado. Por isso aparece como tradicional.

Com base nisso, aderindo termos da etnologia clássica Negrão (2000) classifica cinco práticas costumeiras que ocorrem no país: sistema de casamento preferencial (principalmente no norte de Moçambique onde os sistemas linhageiros são matrilineares), sistemas de territórios consignados (principalmente no sul, onde os sistemas linhageiros são patrilineares e onde há lobolo), sistema de estabilidade dos descendentes nucleares (ocorre na baixa Zambézia, único que permite a recepção e transmissão da herança pela mulher), sistema de dependência do grupo (entre a etnia sena, nas margens do rio Zambeze) e sistema de segurança de três gerações (margens do rio Zambeze - o sistema que ocorria nos Prazos). São essas práticas que, em tese, após o consenso da comunidade local, o Estado passaria a reconhecer e conceder a posse pelo DUAT.

Cada sistema guarda particularidades pelas relações específicas dos grupos de pessoas que neles vivem, das etnias e aquilo que organiza suas relações. Não iremos nos prolongar sobre essas diferenciações, mas podemos dizer que, de acordo com o que compreendemos a partir da apresentação de Negrão (2000), o que determina a herança da terra tem relação com a família e essa é considerada a família alargada, definida pela linhagem, pela ancestralidade. A diferença entre os sistemas está principalmente em termos de gênero, diferenciando-se entre linhagem patrilinear ou matrilinear. Isso recai sobre as regras que marcam as relações matrimoniais e a sucessão sobre o direto à terra e aos filhos após a morte do homem ou da mulher.

Compreendemos que as determinações dessa lógica peculiar que define o sistema costumeiro são de alguma maneira representadas pela autoridade que se apresenta como tradicional, com as ressalvas ao termo que sugere uma forma ontológica de organização social. Anteriormente apresentamos essa hierarquia com base na exposição de Cuahela (1996). Em Tete as determinações da organização social são definidas pelo Mambo e personificada na figura do Nhakwawa, ao menos no que abrange o momento em que Cuahela (1996) aborda. Tendemos a pensar que o que determina a organização no sistema costumeiro não é necessariamente a abstração do valor, podendo ser uma abstração divina, 
um panteão mágico. É nesse sentido que compreendemos o argumento de Negrão (2000: 9) ao dizer, por exemplo, que uma ocupação indevida ou ilegal pode ser sujeitada à punição dos espíritos dos antepassados dos "donos" legítimos da terra em causa. Uma compreensão de legitimidade de uso da terra bastante distinta da forma mercadoria da sociedade moderna, onde o dinheiro é a forma material do que é cultuado pelos enfeitiçados e é com a troca por dinheiro que se tem acesso à terra.

Dito isso, podemos dizer que no processo de herança da terra pelo direito costumeiro entrelaçam-se o mundo dos vivos e o mundo dos mortos, numa compreensão do espaço e do tempo que não é propriamente cartesiana e a abstração que determina a organização social não é o valor, não é um fetiche capitalista. A terra não é entendida como uma propriedade privada enquanto mercadoria.

Negrão positiva a Lei de Terras por ser, para ele, conciliatória ao acatar o sistema costumeiro. Ao mesmo tempo, a lei designa que a terra pertence ao Estado e não pode ser vendida, alienada, hipotecada. Essa relação pode seduzir quem vive num país de terras privadas como o Brasil, por exemplo, pois o processo de nacionalização de empresas e da terra pode ser pensado como de rompimento com a propriedade privada e emancipação da forma capitalista ao não ter a mediação do dinheiro para o acesso e assim entendida como uma política que desestruturou possíveis latifúndios formados pelas Companhias, o que não ocorreu no Brasil, por exemplo, ao fim da colonização.

No entanto, a Lei de Terras foi criada num contexto em que a agricultura era fator dinamizador e entendida como a base de acumulação para o desenvolvimento econômico e numa bem sucedida socialização, a agricultura assenta não só o futuro da agricultura, mas também o programa de industrialização do país (BRAGANÇA \& FIRST). Com esse objetivo, foram formadas as Cooperativas de produção com a formação de Aldeamentos Comunais, em que o Estado socialista ${ }^{66}$ justificava a remoção e concentração das famílias antes dispersas para facilitar a administração, oferecimento de serviços e ao mesmo tempo era a maneira que o Estado compreendia para impulsionar a modernização da agricultura e torná-la mais rentável (CASAL, 1996). Um planejamento para o processo de modernização retardatária (Kurz) que almejava a posterior industrialização nacional. $\mathrm{O}$ Estado socialista organizava, assim, as relações sociais com a imposição das categorias

\footnotetext{
${ }^{66}$ Sobre a imposição do trabalho no período socialista sugiro a leitura de Poder do Poder: Operação Produção e a invenção dos "improdutivos" urbanos no Moçambique socialista, 1983-1988, de Carlos Domingos Quembo. E o livro Antropologia e desenvolvimento: as aldeias comunais de Moçambique, de Adolfo Yañes Casal. Ou ainda pesquisar sobre os campos de reeducação em Moçambique.
} 
para a produção de mercadorias, num processo que podemos considerar tanto quanto de territorialização do capital (HEIDEMANN et al, 2014).

A Lei de Terras de Moçambique passou por mudanças desde a sua criação e acreditamos que o sistema costumeiro por si não as explica, pois compreendemos que essas adaptações acompanharam as formas de reprodução do capital no processo de modernização moçambicano. Explicamos.

Dois anos após a criação da Lei (1977) definiu-se que toda pessoa singular ou coletiva com capacidade jurídica poderia ter um DUAT para fins econômicos privados a um prazo limitado entre 5 e 15 anos (MATOS, 2016: 104). Nessa altura, a lei estatal dava prioridade no acesso à terra ao partido FRELIMO. Sendo assim, entendemos que os aldeamentos comunais, por exemplo, eram prioridade frente outras formas de produção existentes.

Essa política de modernização nacional, influenciada pelo ideal marxista leninista, teria alterado as bases do sistema de produção, ao mesmo tempo em que o modelo de produção coletiva praticado nos aldeamentos comunais não teria vingado (CASAL, 1996). Sendo o próprio modelo insuficiente ou não, destacamos que após a Luta da Libertação que durou 11 anos, os moçambicanos enfrentaram ainda uma guerra de 16 anos. Foram guerras distintas e a segunda não se resume a uma guerra civil entre grupos étnicos em conflito, trata-se de uma guerra que foi inicialmente impulsionada, financiada e de agressão externa. Uma guerra que desestruturou as unidades de produção e sistemas de abastecimentos ao ter provocado milhares de deslocamentos e refugiados, além de ter abalado infraestruturas ao longo do país ${ }^{67}$. Esse período é lembrado popularmente em Moçambique como período da fome.

Em 1986, ano da morte do líder moçambicano Samora Machel e em meio à crise do socialismo, a Lei de Terras foi alterada. Foi ampliado o período de concessão do DUAT passando a ser permitida a concessão de até 50 anos com possibilidade de renovação (MATOS, 2016: 106), ampliou o número de titulares de um mesmo DUAT e permitiu que estrangeiros fossem titulares. Tal mudança foi justificada pelos investimentos em explorações agrárias e industriais naquele contexto em que o país já estava na transição política que levou à abertura econômica ao capital estrangeiro. Nessa altura, o país encontrava-se endividado, sem apoio financeiro e as estruturas políticas estavam frágeis.

\footnotetext{
${ }^{67}$ Para saber mais sobre a guerra civil moçambicana recomendamos a leitura de "A causa da guerra: antropologia da guerra contemporânea em Moçambique" de Christian Geffray.
} 
No livro O colapso da modernização, Kurz (1993: 17) apresenta uma seleção de citações da imprensa que abordam o momento como uma suposta vitória do mundo ocidental em detrimento ao socialismo. Uma delas diz que Moçambique e Angola viram, empobrecidos, as costas ao marxismo. $\mathrm{O}$ autor questiona essa ideia de vencedor, pois nessas formulações aparece como se o socialismo fosse o responsável pelos países então empobrecidos e diz que essa vitória é relativa ao passo que os próprios líderes do ocidente ficaram surpresos com o colapso do sistema real. E, de forma a não colocar os modelos de gestão num conflito em que um devesse superar o outro, ele formula que o socialismo é parte do próprio sistema produtor de mercadorias burguês, e por isso não substitui essa forma histórica por outra (KURZ, 1993: 29). Dessa maneira, entendemos que não tratase de Moçambique ter virado as costas ao socialismo, mas sim as políticas que foram adotadas fazem parte de um mesmo processo e que envolve crise.

A crítica de Kurz (1993) volta-se ao fato de o socialismo não ter substituído as categorias fetichistas da sociedade produtora de mercadorias: salário, lucro e preço. Então ainda que Moçambique tenha na aparência alterado a relação com a terra, manteve relações de trabalho e produção que reproduziam a prática capitalista e o Estado na posição de gestor da produção.

Esse período de colapso foi de grande transformação nas estruturas estatais moçambicanas. Em 1990 a reforma política resultou na nova constituição da República de Moçambique, deixando oficialmente de ser a República Popular de Moçambique. Em 1992 foi assinado o Acordo de Paz e a primeira eleição multipartidária ocorreu em 1994, quando os dois partidos políticos FRELIMO e RENAMO disputaram as eleições.

Diferentemente de quando a Lei de Terras foi criada em que quem tinha prioridade de acesso à terra era a FRELIMO, o novo planejamento estatal colocou a mineração como prioridade sobre qualquer outro uso do solo pela Lei de Minas de 2002 (Lei no 14/ 2002). Para nós isso evidencia a importância que a mineração esteve nesse novo momento da reprodução das relações capitalistas no país. Essa prioridade foi alterada em 2014 (Lei $\left.n^{\circ} 20 / 2014\right)$. No entanto, lembramos que o contrato da Vale S/A e de outras grandes mineradoras foram celebrados entre 2002 e 2014. Ou seja, na altura da última alteração da Lei, a terra já havia sido concedida para grandes corporações em detrimento das famílias que nela viviam e nesse processo as pessoas que viviam na área de concessão da Vale S/A já haviam, inclusive, sido reassentadas.

Tendo exposto o que constitui a Lei de Terras e o momento em que ela foi criada e alterada, compreendemos que na conjuntura atual o fato de o agricultor ter um DUAT 
que oficializa o seu uso da terra é, em lei, uma autorização do Estado. Por mais que o seu direito àquela terra possa ser legitimado oralmente, com testemunhas, a terra pertence ao Estado e é esse mesmo Estado que pode não renovar ou solicitar a terra para conceder para outra finalidade, para outra pessoa, seja ela física ou jurídica. Negrão (2000), inclusive, argumenta que os sistemas costumeiros sofreram mutações com o tempo em decorrência, por exemplo, ao parcelamento das terras, autonomização de segmentos da linhagem, dentre outras interferências. Destaca ainda que as relações de produção destinadas à monocultura (e aqui incluímos a mineração) por concessões legitimadas pelo Estado interferiram no direito costumeiro, ao conceder áreas que pertenciam à determinadas linhagens. Nessas condições que as mineradoras multinacionais, dentre elas a Vale S/A, se inserem legalmente, num processo de concessões de terra pelo Estado.

Compreendemos que a remoção das pessoas de seus lugares de moradia para dar lugar às atividades das corporações interfira nas duas lógicas que organizam as relações sociais e acesso à terra. Tanto pelo sistema costumeiro em que há a relação da ancestralidade e parentesco, quanto na sistema estatal que passa pela mediação do dinheiro ou produção para ter acesso à terra.

Em relação à lógica costumeira, encontramos no próprio Relatório de Impactos Ambientais relações que os técnicos previram como fragilidade pela alteração com a atividade mineira:

Fortes vínculos e sacralização de elementos da natureza. Árvores específicas (Ntondo e Embondeiro) são sacralizadas. A comunidade local considera algumas árvores como herança familiar, onde são realizados cultos e cerimônias. A interferência nestes elementos deve levar em consideração o significado que representam para a comunidade e deve ser discutida com as autoridades comunitárias tradicionais.

Fortes vínculos com os mortos e antepassados. A interferência em cemitérios (remoções) repercute em crenças e valores de grande significado para a população, devendo ser discutida a questão com as autoridades comunitárias e tradicionais. (RDM, 2006: VI.3-20)

Alguns reassentados relataram essa interferência a partir de diferentes situações cotidianas. As áreas que foram concedidas para a mineração estão restritas à circulação de pessoas o que as impede de adentrar nessas imensas áreas que antes tinham referenciais também simbólicos e importantes para as práticas costumeiras. Meu interlocutor, o Sr. Bento, do reassentamento 25 de setembro, argumentou:

O que está a dirigir o nosso país é dinheiro. Agora 2019, aqui, não vamos conseguir chuva. A chuva o que quer? Temos animais lá: leões, jiboia e 
transforma alguma coisa com o antepassado: fazia cerimônias até cair chuva. Agora não. Kalambo: aquela montanha [aponta indicando], tem água ali. Que sai: assim... Todos os animais, toda a comunidade daqui até Matema bebiam daquela água. Sai das pedras. Tomar banho... Porque lá tem espírito: o nosso avô, o pai avô. Em Kalambo dava para cavar, cavar, até ficar uma bacia assim pra 70, 80 pessoas tomarem água, tomar banho. Lá, Kalambo, tás a ver? Agora aqui não. (BENTO, 2017)

Se por um lado o impedimento de acessar a área que foi concedida é também impedimento de acessar uma nascente de água, por outro lado estranhamos a relação dos leões e jiboias com a chuva. No romance de Coelho (2013), encontramos um episódio que parece ir a encontro ao que meu interlocutor narra e tomamos como sugestão de possíveis interpretações. No romance, o narrador busca informações no Arquivo Municipal de Moçambique sobre um episódio em que uma mulher branca, da elite da Companhia Carbonífera, teria ido participar de um ritual no Zóbue e por isso foi punida. Então o narrador do romance encontra um documento trocado por administradores do estado:

É costume tradicional, e que remonta a uma época muito recuada, os habitantes desta região dirigirem-se ao monte Basimuane a fim de procederem à invocação da chuva quando verificam que esta não cai na época própria, cerimónia a que dão o nome de M'patso. Reunidos os habitantes daquelas povoações, dirige-se o cortejo ao monte com os velhos na frente, e quando chegam a um local onde há água ajoelham-se todos, e um velho ou uma criança do grupo oferece ao espírito da jiboia um bolo de milho e mapira, previamente preparado para o efeito. A pessoa escolhida para fazer a oferta conversa com a jiboia, pedindo-lhe chuva, e terminada a cerimônia dançam e cantam ao som de palmas e tambores, e neste ritmo regressam a casa, continuando a festa até ao dia seguinte. Não é o feiticeiro a figura principal da cerimónia, dado que o feiticeiro é quem geralmente guarda a estrela que produz chuva, para com ela fazer os seus medicamentos. Assim, não é chamado nem desejado na aludida cerimónia (COELHO, 2013: 139).

A partir desse trecho conseguimos melhor compreender o que o sr. Bento tenta, a partir de sua cosmovisão, nos explicar ao atribuir a falta de chuva pela ausência de jiboias e leões, pois assim não é possível realizar o ritual, o culto dos antepassados ${ }^{68}$. Noutro trecho Coelho (2013) segue:

\footnotetext{
68 Tomamos a explicação de Bono (2015: 41), que se baseou nas formulações de Vincent Mulago: Por culto dos antepassados se entende tudo quanto serve para meter-se em relação com os seres invisíveis, que são considerados seres dotados de uma força superior à força da natureza e capazes de reproduzir o bem e o mal [...]. Estes permanecem presentes entre os seus parentes, não só na memória, mas como uma presença real. O culto cotidiano, os sacrifícios e as ofertas tem como fim prevenir ou resolver todas as necessidades.
} 
Desde há muito que ouço falar em mortos que escolhem vivos para se expressar. Em todo o extenso território da margem direita do Zambeze vigora a crença no m'phondoro, o ilustre ou poderoso que, depois de morto, se transforma em leão e escolhe um mortal - o caixa, ou demiurgo - para seu interlocutor com o mundo terreno, sobretudo para transmitir a sua palavra no seio dos vivos (COELHO, 2013: 214).

O leão seria uma forma totêmica de comunicação entre os mundos dos vivos e dos mortos? A impossibilidade de continuar cerimônias como essa altera o que representa o chefe tradicional perante a comunidade? Altera a organização social entre essas pessoas?

A área em que as pessoas reassentadas viviam, como dissemos, está cercada. Além da cerca, que é um impedimento físico e constrangedor a quem sempre circulou pelo lugar, há a força física, armada, sob a justificativa da segurança para adultos e crianças diante das imensas máquinas que circulam na área de mineração. Contraditoriamente, em 2017, ao chegar em Moatize para pesquisa de campo, havia grande indignação dos moradores, pois dada a necessidade de circulação, seja para visitar familiares, coletar matéria prima, dirigir-se em locais de referência ritualística dentro de suas lógicas peculiares, a barreira física e humana colocadas como necessárias para a proteção da vida de pessoas, voltou-se contra essas mesmas pessoas em defesa do que é considerado de direito da empresa como quem defende sua propriedade privada. Meus interlocutores explicaram que a situação ocorreu após moradores abrirem passagem para entrarem na área que está sob concessão para extração do carvão mineral, mas onde a exploração ainda não foi iniciada. A finalidade era acessar bebedouros de gado e coletar lenha com que fabricam carvão vegetal. Como a empresa fechou novamente essa abertura da cerca, moradores reuniram-se para o que chamaram de greve, mas a polícia fez uso de armas de fogo contra eles e afinal uma pessoa foi atingida sendo que sequer estava nesse grupo que se manifestava (JORNAL NOTÍCIAS, 2017).

A concessão da terra é da empresa para a exploração do carvão mineral e para reprodução do capital com seu fim em si. Para manter o contrato e o controle do que o Estado acordou com a empresa, faz-se uso da violência pela polícia ou ainda segurança privada da própria empresa diante da fragilidade em termos de estrutura da polícia moçambicana. Violência contra pessoas, para cumprir o contrato.

Retomando nosso argumento de que práticas ditas costumeiras foram alteradas com o processo de reassentamento, dada a impossibilidade de acessar esses lugares compreendidos como sagrados há outro fator transformação nas relações que é o fato de famílias alargadas terem sido divididas entre os dois reassentamentos, conforme melhor 
iremos apresentar nos próximos itens, pois acreditamos que tenha de alguma maneira interferido no processo de determinação de herança de terra e nos próprios cultos aos antepassados.

Quanto ao direito estatal e a sociedade produtora de mercadorias, as relações de produção também foram alteradas conforme também iremos melhor apresentar nos próximos itens. O que a pesquisa de campo revela é que, ainda que a lei de terras apareça como a garantia do acesso à terra pelo DUAT, os moradores dos reassentamentos não tem o contrato do direito mesmo após quase 10 anos vivendo naquela nova área. Essa é uma reivindicação principalmente dos membros das associações, o que nos parece como necessidade de reconhecimento estatal pelo medo de serem novamente reassentados e, nessa reivindicação, o direito costumeiro não parece ser suficiente.

Para finalizar o item, apresentamos que, durante o período de pesquisa em campo em 2017, houve uma conferência na cidade de Maputo em comemoração aos 20 anos da Lei de Terras. Nessa conferência foram lembradas as alterações na lei e foram expostos por lideranças dos movimentos sociais e pesquisadores os conflitos de terra. Os conflitos que foram apresentados são em decorrência principalmente do projeto ProSAVANA ${ }^{69}$, que é um projeto de expansão do cultivo de soja na savana, que inicialmente foi uma parceria entre a Embrapa, governo brasileiro e governo Japonês, semelhante ao que foi o Prodecer no Brasil. No evento foram também expostos conflitos relacionados ao acesso à terra em consequência da mineração na Província de Tete. Essas lideranças questionaram aos representantes do governo suas posições e procedimentos para a resolução desses conflitos entre os moradores e as grandes concessões para as multinacionais.

$\mathrm{O}$ argumento dos dirigentes foi que a lei de minas foi adaptada em 2014 com o objetivo de assegurar o acesso à terra, por isso tirou-se a prioridade da mineração. Os dirigente afirmaram ainda que há possibilidade de novos ajustes e, com isso, o argumento deles não foi refutado em suas contradições. Contradições que são entendidas nesse momento por haver relações irreversíveis e independente da lei ou a mudança da lei não há retorno, além disso a lei foi alterada após as concessões para as grandes mineradoras Vale S/A, Riversdale e Jindal já terem sido feitas. De qualquer maneira, o evento foi de comemoração.

\footnotetext{
${ }^{69}$ Para saber mais sobre o ProSavana recomendamos a leitura de Alves, F. J. (2016). O ProSAVANA e o desenvolvimento contraditório da agricultura em Moçambique. São Paulo: Monografia apresentada ao Departamento de Geografia da FFLCH-USP.
} 
O que é possível concluir do que foi exposto na conferência é que, sendo a terra do Estado e o Estado entendido por eles como uma proteção aos moçambicanos, a lei está para atender os moçambicanos, seja os que vivem na cidade ou no campo. Então, quando há conflito ocorre porque a lei não é cumprida ou ela precisa de ajustes, e nesse ponto, a fala dos dirigentes está de acordo com o que parte dos movimentos sociais reivindicam, num sentido reformista de lidar com a contradição cuja solução dos conflitos se dá pela própria gestão do Estado.

\subsection{A divisão dos reassentamentos e o esfacelamento da unidade de produção e consumo}

Para realizar a pesquisa em campo no distrito de Moatize foi necessária a autorização de duas autoridades. A primeira foi a autoridade estatal representada pela administração distrital de Moatize: carta impressa com justificativa, sala de espera, assinatura e carimbo. Herança da burocracia estatal portuguesa e soviética. Foram outros pesquisadores que estiveram no distrito anteriormente e os mediadores e membros das associações que orientaram a pedir tal autorização para circular no distrito como medida de segurança. Noutro momento, ao chegar no reassentamento considerado rural, o reassentamento Cateme, membros das associações que estavam na mediação para a aproximação com a comunidade e orientação aos códigos locais levaram até uma chefia local, o que não aconteceu no reassentamento 25 de setembro, considerado urbano. Esse foi momento de outro pedido de autorização para circulação no lugar, mas dessa vez não do Estado moçambicano e sim daquele que foi apresentado como chefe local. Ele não se identificou como régulo, mas sim administrador de $2^{\circ}$ escalão. Nesse caso, a necessidade de autorização por parte dele foi justificada numa relação de respeito ao lugar, não exatamente por segurança como no caso anterior.

Moradores disseram que esse chefe local foi escolhido em acordo com toda a comunidade quando já estavam em Cateme, ou seja, ele não era chefe nos bairros em que viviam antes de serem reassentados, nem tampouco tem antepassado que o foi.

De acordo com as pessoas com quem conversei em ambos reassentamentos e com base no Relatório de Impacto Ambiental (RIMA) do empreendimento, antes de serem reassentadas, essas pessoas viviam principalmente em dois bairros: Mithethe e Chipanga. O RIMA é resumo do Estudo de Impacto Ambiental (EIA) e foi finalizado em 2006. O levantamento e a análise dos dados foi realizada pelas empresas Diagonal, ERM e 
Consultec Associados, duas empresas brasileiras e uma moçambicana. No relatório estão identificadas as lideranças em Chipanga classificadas como: secretários, chefes de unidade, chefes de quarteirão, chefes de 10 casas. Já em relação a Mithethe foram identificados: régulo, secretário, chefes de zona, chefes de zoninhas (RDM, 2006: IX.154), caracterizando assim diferentes escalas da autoridade local e que parece juntar a autoridade estatal com a local e nessa caracterização ficam também marcadas diferenças entre os dois bairros.

Para o planejamento do que veio a ser os reassentamentos e como as famílias seriam divididas, um trabalhador que atuou na comissão de reassentamento para a empresa Diagonal relatou as etapas da elaboração do plano de reassentamento. Ele apontou que foi feita uma caracterização quantitativa e qualitativa das famílias que viviam nos bairros: o número de famílias, o número de membros na família, número de escolas e por fim qual a tarefa principal do chefe da família que, na ordem patriarcal das relações, esse chefe da família foi entendido como o homem. A tarefa identificada pelos técnicos foi compreendida como forma de reprodução dos membros da família, nesse caso considerada a família nuclear. Esse foi o elemento que deu base para a divisão das pessoas entre os dois reassentamentos: 25 de setembro e Cateme.

Então quais seriam essas tarefas? Para relatar sobre essas relações nos bairros que precederam os reassentamentos, o chefe local de Cateme indicou um morador desse mesmo reassentamento e que é antigo morador do bairro Chipanga: o Sr. Lionel. Esse senhor tinha um enredo de histórias e das mais interessantes ao longo de toda a pesquisa, por justamente transitar entre elementos do Estado moçambicano com as relações que envolvem a instituição e as mudanças nas relações de trabalho na mineração, e elementos costumeiros com referências que envolvem relações familiares, ritos e feitiços talvez sem perceber o quanto poderia parecer nebuloso e repleto de incompreensão da minha parte essa última cosmovisão.

O Sr. Lionel contou histórias que vem antes daquilo que experienciou, pois compartilhou também aquilo que lhe foi contado pelos seus familiares e transmitidos pela oralidade. Ele iniciou a narrativa explicando a origem do nome do bairro Chipanga: uma rocha onde depositavam os corpos dos mortos daquele pequeno povoado que ali havia se instalado após fugirem de Macanga.

Macanga está ao norte de Moatize, numa área bastante próxima à área onde estava a Sena Sugar Estates e que a partir de 1914 havia o cultivo de cana de açúcar com o trabalho explicitamente forçado. Nesse mesmo período muitos moçambicanos daquela 
região foram recrutados para a Guerra Mundial, o que também teria causado fugas. É 1914 a data que Lionel relata como marco dessa suposta fuga para Chipanga num processo que teria aumentado a concentração de pessoas naquela zona.

O próximo marco temporal de meu interlocutor foi 1940, altura da construção da linha férrea que conecta o distrito de Moatize ao porto da cidade da Beira, por onde seria escoado o carvão extraído do subsolo daqueles bairros pela Companhia Carbonífera. O Sr. Lionel explicou que tornou-se necessário retirar a rocha (panga) mortuária do bairro para que o trilho atravessasse aquele lugar. No entanto, os engenheiros portugueses daquele período tiveram dificuldades em retirar a rocha. Talvez o leitor imagine que naquele período não houvesse técnica que permitisse tal feito, mas na explicação do Sr. Lionel as máquinas e técnicas não aparecem, pois para ele o que impedia estava à parte disso: precisava fazer um ritual em respeito aos antepassados cujos corpos foram nela depositados para conseguir retirar a rocha. Nessa moradia, os antepassados se convertem em deuses (COUTO, 2009: 123).

Ironicamente, atualmente chipanga premium HCC é a classificação de um tipo de carvão que a mineradora Vale S/A extrai em imensas quantidades do local desses antigos bairros e transporta em máquinas imensas, classificadas como as mais modernas da mineração. O carvão com nome de rocha mortuária, chipanga, tem uma característica particular que no setor mineiro é caracterizado como de qualidade, utilizado para produzir ferro, aço e cimento. Após o carvão ser extraído, a paisagem que fica em Moatize é de uma imensidão cinza e monótona, com poucos embondeiros ${ }^{70}$ mantidos em meio ao carvão remexido. O pó cinza do mineral se espalha com o vento pela comunidade ao lado provocando sérios problemas de saúde.

O bairro Chipanga foi narrado por Lionel como local para onde pessoas fugiam do trabalho forçado, do chibalo. Ao retomarmos os relatos que apresentamos no primeiro capítulo, sobretudo sobre o período em que a Companhia Carbonífera já estava em funcionamento, lembramos que alguns interlocutores disseram que para lá, ao contrário, foram levados aqueles que foram enquadrados como vadios e assim foram cumprir o trabalho forçado. De qualquer maneira, a mobilização do trabalho explicitamente forçado está na história da formação do bairro e nele viveram pessoas que trabalharam nos Caminhos de Ferro, na Companhia Carbonífera e posteriormente na CARBOMOC e outras possíveis empresas.

${ }^{70}$ Árvores do tipo baobá 
Como a exploração do carvão era de forma subterrânea, os moradores de Chipanga continuavam a residir sobre aquele lugar. Um interlocutor narrou:

Lá onde eu morava havia 2 minas. A mina estava ali [aponta para um lugar bastante próximo] e a pessoa aqui, não havia problema, não havia poeira. Vivíamos na base da agricultura e pastorícia. Nossos avós conseguiam sobreviver. Água era gratuita, energia era da Companhia Carbonífera. O custo era barato (BENTO, 2017)

Essa é uma importante diferença quando comparado à conjuntura atual, pois a mineração não impedia a continuidade das práticas nas machambas realizadas pelas mulheres, ainda que os trabalhos explicitamente forçados tenham tirado os homens de possíveis atividades realizadas nesse contexto familiar. Essa é uma memória viva em Moatize e muitas das narrativas frisam esse ponto.

No período da guerra civil (1976-1992), também chamada de agressão externa, Mithethe era passagem de guerrilheiros que buscavam alimento nas machambas e realizavam saques no povoado. Acreditamos que o mesmo se dava em outras zonas em que havia machambas, pois entre os relatos está que nesse período Chipanga era tido como lugar mais seguro do que Mithethe. Para Chipanga migraram pessoas que viviam nas margens do rio Zambeze que era entendida como área perigosa.

Para seguir esse processo histórico, questionei a alguns reassentados sobre trabalhos que eles realizavam durante o intervalo entre o encerramento das atividades na CARBOMOC e a chegada das mineradoras multinacionais, em que a primeira a iniciar as atividades foi a Vale S/A. A principal questão buscava preencher uma lacuna: em que eles trabalharam e como se reproduziam durante esse período de mudança no planejamento estatal e atual crise nas relações de trabalho? Já estariam esses trabalhadores em crise?

Para narrar esse período, um ex morador do antigo bairro Chipanga explicou a dinâmica entre Mithethe e Chipanga. Ele descreveu Chipanga como um bairro em que as casas eram principalmente de alvenaria, havia pessoas que tinham trabalho com salário e faziam serviços na vila ou na cidade de Tete. Mithethe, por sua vez, estava à margem do Chipanga, com mais casas em pau-a-pique ou caniço ${ }^{71}$ e menos pessoas que tinham trabalhos assalariados. $\mathrm{O}$ aumento da concentração de pessoas em Chipanga teria levado pessoas a avançarem mata adentro para cultivar as machambas, expandindo aquela pequena fronteira, enquanto em Chipanga a terra esgotava-se em fertilidade por ter sido

\footnotetext{
${ }^{71} \mathrm{O}$ que explica o próprio nome do povoado, pois thethe significa caniço na língua local e é o que dá nome para a própria província: Tete.
} 
cultivada sem descanso ou ainda a área de cultivo teria diminuído pelo parcelamento da terra em consequência do aumento de membros nas famílias.

Muitos narraram que realizavam: marcenaria no fabrico de móveis, corte de lenha e produção de carvão vegetal, olarias nas várzeas dos rios, principalmente o rio Moatize (Ver anexo II). A matéria prima para a produção dessas mercadorias era coletada nas áreas próximas de suas casas, sem necessariamente a mediação pelo dinheiro, por isso o dinheiro não era uma condição para iniciar a produção. São atividades em que não havia grandes intermediários, no entanto, esses pequenos produtores dependiam de pessoas da vila ou da cidade para comprarem os produtos. Esses sim tinham salário, trocavam pelas mercadorias e era por eles que os antigos moradores de Chipanga acessavam o dinheiro.

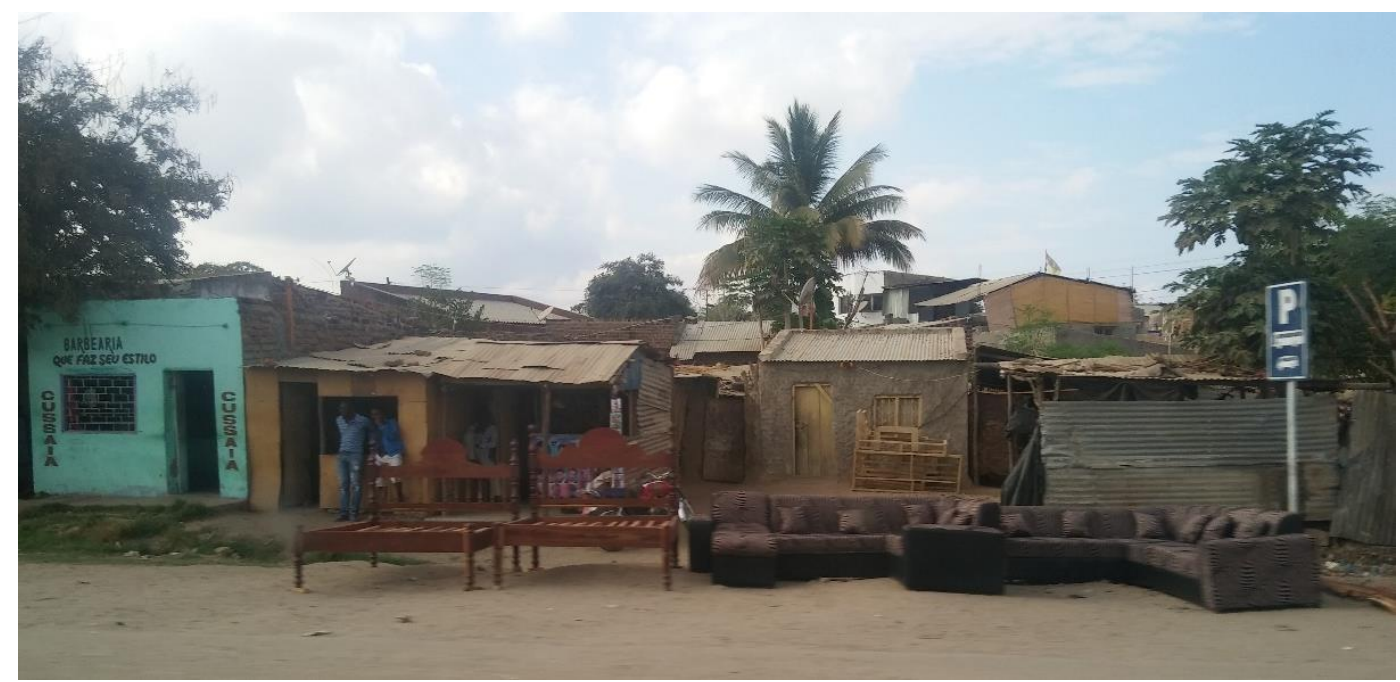

Figura 5: Na principal avenida na vila de Moatize muitas pessoas expõem em frente às casas móveis que fabricam e estão a vender. Fonte: Viviane Alves Vieira - 2017

Moradores dos reassentamentos argumentaram que realizavam as vendas desses móveis e tijolos em quantidade para compradores que se deslocavam até Chipanga e afirmam que foi com tijolos produzidos por eles que foram construídas casas em diferentes bairros de Moatize e na cidade de Tete. Os pesquisadores que realizaram o RIMA e o Plano de Reassentamento concluíram que havia uma interdependência entre os povoados rurais e as sedes polarizadoras urbanas (Tete e Vila de Moatize) do ponto de vista comercial e produtivo. Possíveis interferências nessa "rede de cooperação" podem acarretar em desequilíbrios econômicos (RDM, 2006: VI.3-91).

Podemos dizer que a produção de tijolos foi a atividade mais citada e é com base nela que são reivindicadas possíveis indenizações pagas pela mineradora Vale S/A, pois a remoção deles do antigo bairro e a vedação da área retirou-os das proximidades dos rios 
onde coletavam os sedimentos, sendo impedidos de dar continuidade nessa importante prática.

A pesquisa revelou que a circulação de dinheiro é e já era bastante pequena e que outras relações também não estavam mediadas pelo dinheiro. No RIMA constam várias espécies vegetais que eram encontradas nas proximidades das casas, onde hoje se extrai o carvão e tal vegetação já não existe mais, e que eram usadas para diferentes finalidades. Constam na lista espécies usadas para fazer objetos domésticos como esteiras, peneiras, cobertura de casas, celeiros, vassouras, esponja de banho. Constam plantas alimentícias tanto para pessoas quanto para os animais que eram criados. Constam ainda plantas para curar doenças identificadas na medicina científica como tosse, diarreia, epilepsia, impotência sexual, problema de útero, para tratar picadas de insetos. E havia ainda plantas que foram registradas pelos técnicos, com base na pesquisa de campo que fizeram, como "para fazer amuleto", "proteger contra trovoadas", "para divórcio", "dar sorte" ou ainda "usadas em sessões espirituais".

Desse contexto, o funcionário da Diagonal argumentou que a maioria das pessoas realizava as tarefas identificadas como olaria, venda de lenha e agricultura e eram poucos os moradores que tinham vínculo com o trabalho - aqui compreendemos o trabalho em sua forma autonomizada - e estes trabalhavam na vila de Moatize ou na cidade de Tete. O RIMA, resultado do trabalho em que ele participou, apresenta assim que $22 \%$ dos chefes de família tinham situação ocupacional ligada a empregos formais, $46 \%$ dos chefes tinham renda inferior a 1 salário mínimo e 92\% dos agregados familiares possuíam machambas (RDM, 2006: IX.15-3).

Sabemos que as machambas era uma atividade realizada predominantemente pelas mulheres, conforme ainda apresentaremos melhor, mas destacamos que foi registrada como uma característica coletiva, uma atividade que representa um grupo familiar, em detrimento dos outros dados que são apresentados como exercidos pelos homens individualmente, com o trabalho autonomizado, ainda que o dinheiro obtido pudesse ter uma finalidade de uso que fosse coletivo. Chamamos atenção, sobretudo, ao fato de as machambas fazerem parte da reprodução da maioria desses grupos familiares, o que significa que as pessoas não dependiam exclusivamente da venda da força de trabalho para ter acesso a alimento, diminuindo o peso de importância do trabalho assalariado para a reprodução básica dessas pessoas.

Mesmo com os estudos realizados e com esses dados que apresentamos pelo próprio RIMA, os agregados familiares, assim chamados no relatório, foram divididos no 
processo de reassentamento. Para a divisão foi considerado predominantemente o fator trabalho em detrimento das machambas, numa desestruturação dessas relações que se complementam, colocando em desconexo a relação de produção de alimentos para consumo e venda da relação dos trabalhos formais ou informais.

A divisão entre o reassentamento urbano e rural colocou como determinante o fator trabalho. Família foi considerada a família nuclear. Sendo assim, as pessoas não foram reassentadas contemplando a forma da família alargada conforme apresentamos ser de suma importância em Moçambique, quando apresentamos as relações do sistema costumeiro. Com isso, irmãos, tios, primos foram divididos entre os dois reassentamentos: Cateme e 25 de Setembro (Ver anexo III-b), colocando membros de uma mesma família distantes.

O reassentamento Cateme é o reassentamento classificado como rural. Nele foram reassentadas as pessoas em que a produção nas machambas foi a principal atividade identificada pelos técnicos, se não a única atividade desenvolvida, por isso, em tese, nesse reassentamento essas pessoas teriam uma área para fazer machamba. No entanto, esse reassentamento está localizado em área pedregosa, de solos inférteis e os moradores tem dificuldade em acessar água e insumos. A água é coletada por poços que estão distribuídos ao longo da área do reassentamento, foram construídos e são mantidos pela mineradora Vale S/A. Para os moradores é uma água que não serve: é salgada e argumentam que, por ser área de mineração, a água causa danos à saúde. Muitos moradores relataram que em consequência ao uso dessa água há quem urina sangue.

Podemos visualizar no anexo III-b que Cateme está distante de outros bairros formados e a aproximadamente $40 \mathrm{~km}$ da vila de Moatize. Nesse reassentamento as casas são de alvenaria, padronizadas e alinhadas por quarteirões, distinguindo do sistema de organização das casas quando observamos nas “zonas”, ou nas "aldeias”, ou seja, em áreas que poderíamos dizer que são rurais. A empresa mineradora coloca como um fator positivo o fato de as casas serem de alvenaria, pois a maioria dos moradores desse reassentamento vivia em Mithethe e tinha casa construída em pau-a-pique ou caniço. No entanto, essas casas de alvenaria apresentam atualmente muitas rachaduras, problemas na estrutura e os moradores temem essa degradação, pois não tem dinheiro para reformá-las. Afinal, essa também se tornou uma nova necessidade que foi colocada na vida dessas pessoas, visto que antes coletavam os materiais com que construíam suas casas.

Em Cateme há escola primária e secundária, uma "fazenda modelo" e foi formada uma cooperativa de avicultores. Os relatos em campo apresentam que a escola primária e 
principalmente a secundária mantém alunos predominantemente de outros distritos. Trata-se de um colégio interno e que é referência nas proximidades, por ter, inclusive, ensino em inglês ${ }^{72}$, mas lembramos que naquele reassentamento muitos falam apenas a língua materna: nyungwe. Assim, a maioria dos alunos não é de crianças do reassentamento.

A fazenda modelo é um projeto da Vale S/A para cultivo de hortaliças. Na área dessa "fazenda", a empresa instalou um sistema de rega e instalou estruturas que protegem algumas culturas do sol de Tete, naquele reassentamento que o acesso à água está entre as maiores dificuldades.

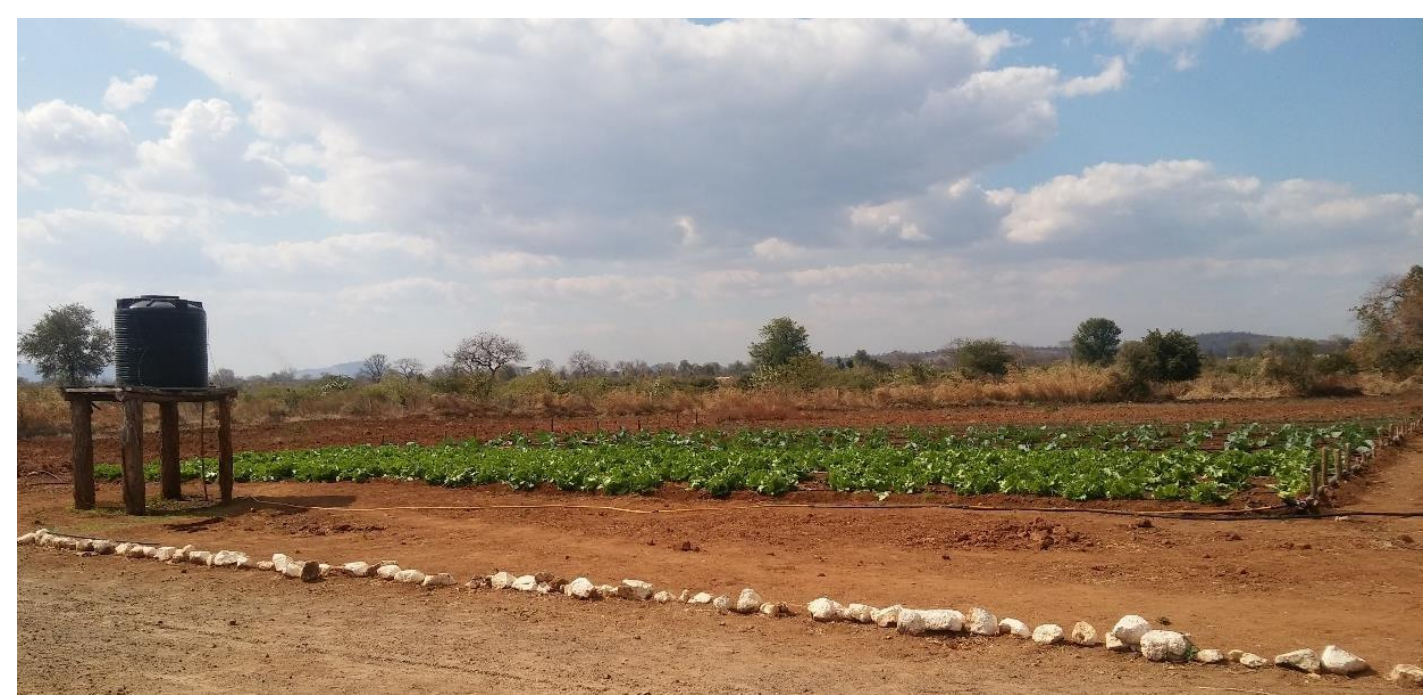

Figura 6: Área da fazenda modelo junto à caixa d'água exclusiva para tal atividade. Fonte: Viviane Alves Vieira2017

Arbitrariamente, essa área é colocada como "modelo", mas as condições de cultivo não são as mesmas para os moradores para que eles possam seguir o exemplo. Assim, nessa pequena área organizada e com suporte técnico de funcionários da empresa, é possível desenvolver algumas culturas, sendo a principal o tomate. Para participar do projeto os moradores devem se inscrever e se dedicar a ir cultivar. Então a segunda arbitrariedade: a produção não é para quem produziu, não fica no reassentamento, mas sim é doada pela empresa para o Instituto Nacional da Acção Social (INAS). A consequência é a "Fazendo Modelo" foi apontada pela empresa como um projeto de baixa adesão dos moradores.

${ }^{72}$ Em Cateme há a atuação da Organização Não Governamental Peace Corps. 
Já a Cooperativa de avicultores foi formada para a produção de ração das galinhas. Em Cateme há um galpão para produção e armazenamento da ração feita com milho e gergelim, com uso de máquina que foi comprada pela Vale S/A. No entanto, os produtores não tem clientes, pois estamos falando de um reassentamento que está a 40km de distância da cidade, distante de outras localidades e assim esses produtores tem dificuldades de divulgar, transportar etc. No próprio reassentamento não tem compradores por falta de dinheiro e os moradores dos distritos mais próximos não se deslocam até lá para comprar, dada a distância. Dessa forma, a venda não acontece e não desenvolve nova produção, ou seja, a atividade não se reproduz.

O reassentamento 25 de setembro, por sua vez, é classificado como urbano. Para esse reassentamento foram encaminhadas as pessoas caracterizadas como trabalhadores assalariados ou que realizavam trabalhos informais em serviços prestados na Vila ou na cidade de Tete. Esse reassentamento está localizado na vila de Moatize, isso significa que está próximo à estação de trem, ao centro comercial e administrativo de Moatize e relativamente próximo à cidade de Tete, por isso podemos dizer que ele está mais integrado ao distrito pela proximidade. Nesse reassentamento as casas também são em alvenaria e estão numa disposição de maior densidade, por isso não tem área para machambas, cuja justificativa está por ser um reassentamento urbano, como se, pelo fato de terem salário (e isso não significa que seja regular), ou prestarem serviços, a produção nas machambas fosse desnecessária ou não fizesse parte das práticas de reprodução daquelas pessoas. Essa é uma compreensão que contraria o que visualizamos ao longo do país, inclusive na capital Maputo, em que é bastante comum ter machamba mesmo em áreas urbanas.

As áreas ao redor do reassentamento 25 de setembro estão cercadas. Isso impede práticas de coleta de matéria prima, pois além de estar próximo da vila o reassentamento está também próximo às áreas de concessões das mineradoras. Essa proximidade à área de exploração torna o dia a dia dos moradores problemático em consequência das explosões que são barulhentas e aumentam as rachaduras das casas, além da poluição do ar e sonoro com todos os constrangimentos que são gerados a partir disso. 


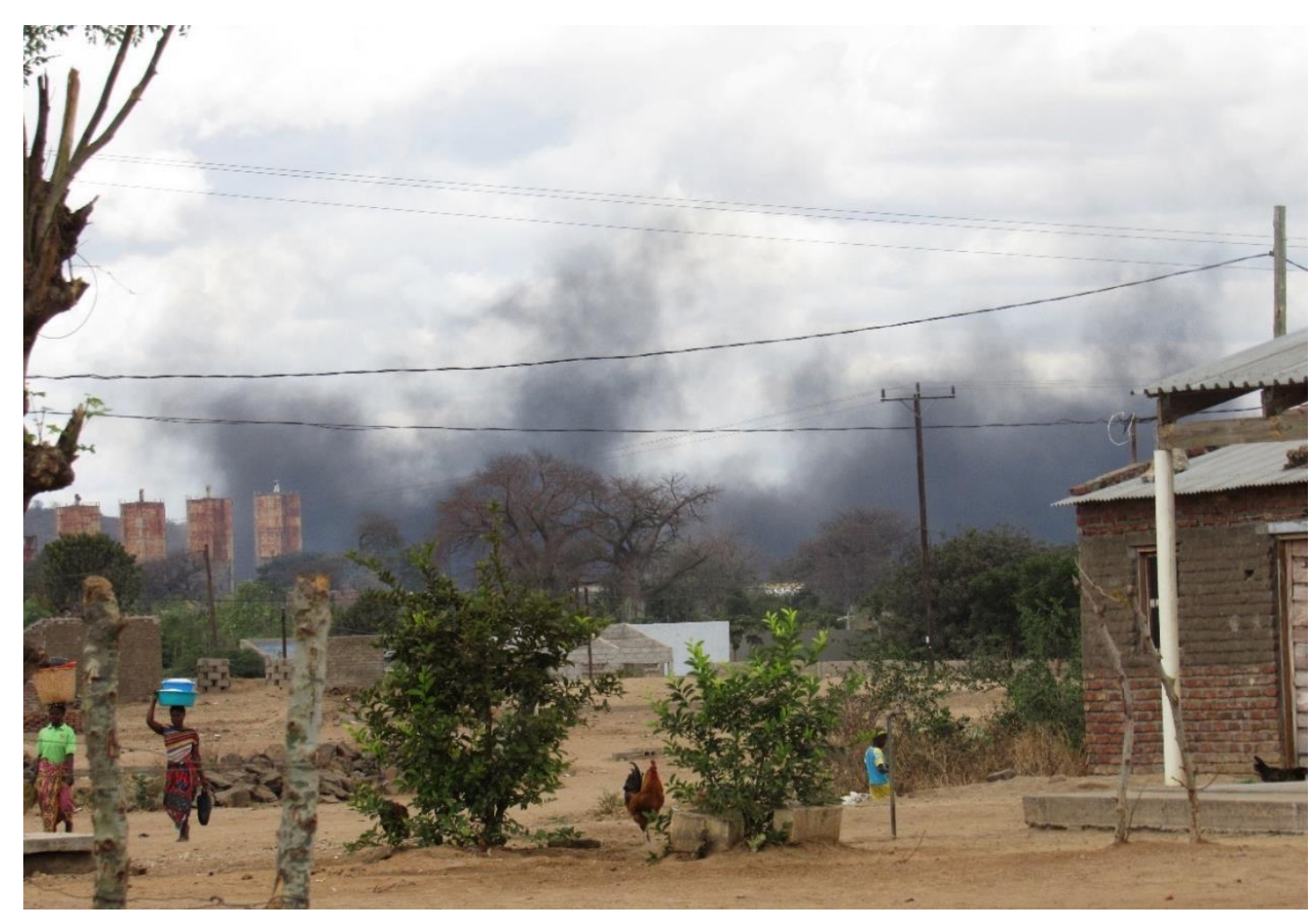

Figura 7: Reassentamento 25 de setembro durante explosões na área da mineradora Vale S/A. Fonte: Viviane Alves Vieira - 2017

Os interlocutores em pesquisa de campo citaram inúmeras vezes os problemas que tem em consequência da poluição do ar, pois contamina alimentos expostos a céu aberto, causa muitos problemas respiratórios. Esse é um problema particularmente desse reassentamento e de outros bairros próximos à área de concessão das mineradoras.

Outra característica própria desse reassentamento, é que no 25 de setembro não há poços para coleta de água como em Cateme. A distribuição da água é feita pelo Fundo de Investimento e Patrimônio do Abastecimento de Água (FIPAG) que é uma instituição pública e o acesso à água aos moradores do reassentamento é por meio de uma torneira em frente de cada casa e o uso é controlado, pois é preciso pagar. Como estamos falando de um lugar em que há escassez de dinheiro, o acesso à água em troca de dinheiro resulta na escassez de água na mesma medida. O problema é agravado pela distância do rio ou outros meios de acessar água. Ou seja, o processo autonomizou esse serviço e o dinheiro tornou-se a forma para ter acesso ao que passa a ser compreendido como um recurso e que é comprado, a água. Passa por tratamento e entra num sistema, uma rede para distribuição, cujo controle e venda é feito de forma institucionalizada, torna-se mercadoria. O que pode aparecer como uma relação justa tendo em vista que Moçambique é um país de grande incidência daquilo que a medicina moderna reconhece como cólera. Mas tornou-se uma nova necessidade e aumenta a dependência do dinheiro. 


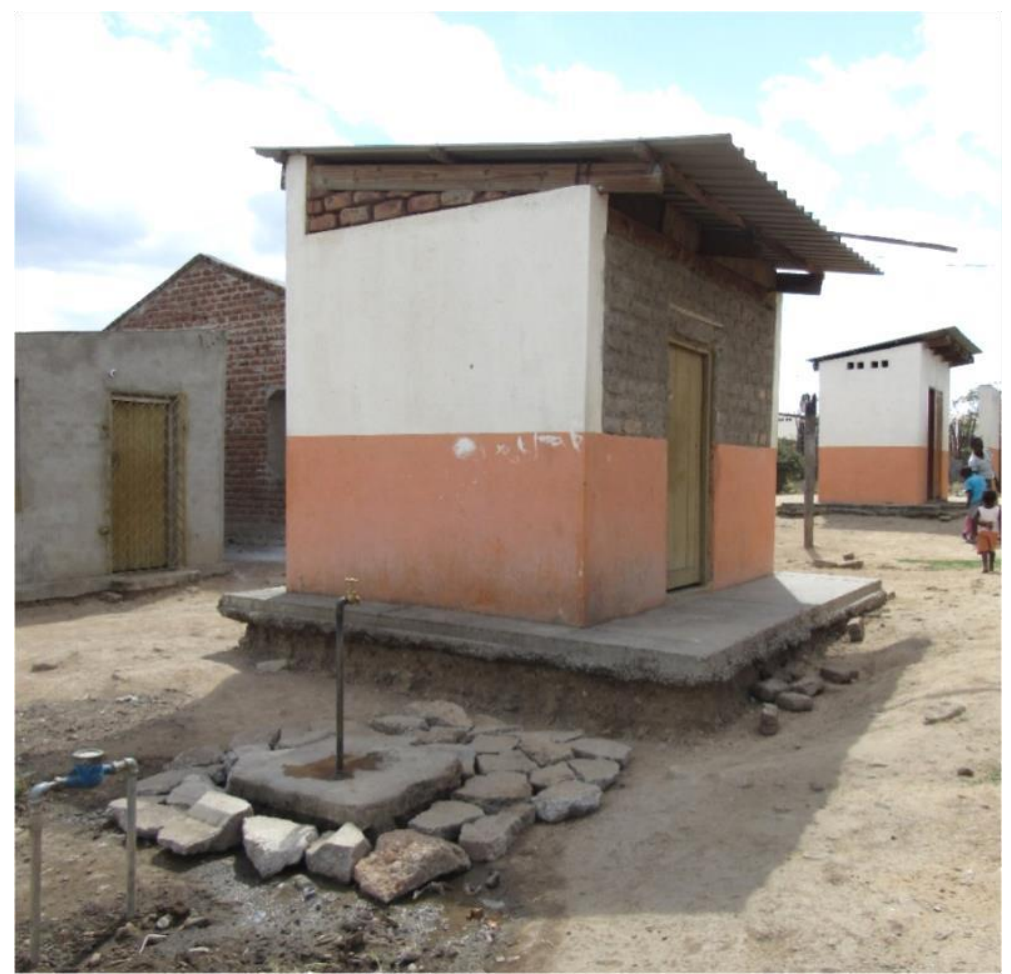

Figura 8: Reassentamento 25 de setembro. Fonte: Viviane Alves Vieira - 2017

A imagem acima mostra uma casa do reassentamento 25 de setembro e destacamos a torneira, conforme mencionamos. Quando os moradores não pagam a conta de água, o consumo é interrompido e por isso muitas torneiras ao longo do reassentamento estavam vedadas. Na foto acima chamamos atenção ainda ao fato de que esse é o cômodo que se destinaria inicialmente à cozinha de uma das casas e assim como em tantas outras casas, esse cômodo foi modificado ao ser erguido o muro até o telhado, tornando um cômodo fechado e para outros usos. Em Moçambique o ato de cozinhar geralmente é realizado nos quintais das casas, visto que geralmente o fogo é alimentado com carvão vegetal. No entanto, no momento de tirar a fotografia a intenção principal foi registrar outro incômodo dos moradores da casa: o medo da casa ruir, visto que a cada chuva, aumenta a erosão do solo e, como dizem com frequência, as casas não tem vigas. É como se fossem casa feitas para não durar.

No reassentamento 25 de setembro há ainda um hospital financiado pela Vale S/A e não há escola. Ao lado dele está o condomínio construído para os trabalhadores migrantes empregados na empresa, mas migrantes moçambicanos de origem principalmente da cidade de Maputo e Beira.

Um de meus interlocutores narrou: 
O reassentamento foi mal feito. Eu já fui ao Brasil e sei que a Vale sempre faz reassentamento que deixa a desejar. A Vale veio para ficar: vão ficar 50 anos. Se vão ficar tanto tempo aqui, tinham que fazer uma coisa digna. As casas que construíram vão cair. Se os moradores estivessem como passageiros, como quem está a fazer estradas e quando acabou a obra vão se embora, tudo bem. Agora esses vão ficar aqui e vão ter muitos problemas. Eles [a serviço da Vale] disseram: "Nós vamos fazer casas boas, as pessoas estavam a viver em palhotas, casas de chapa", mas se eu vivo numa casa de palhota, coberta de palha, epah! Eu nasci lá, vivi lá e sou assim! É aquilo que me agrada. Agora dizer que você vai sair desse ambiente, vai viver até em São Paulo, pode ser bom, mas eu não vou aguentar o ambiente, tá a ver? Aqui: lenha a gente corta no mato, água a gente não paga nada, não sei o que, não sei o que. Agora eu vou na cidade e ter que comprar tudo!? Pra mim não favorece (RAUL, 2017).

Quando ele diz que tem que comprar tudo, acreditamos que ele se refira à necessidades que são criadas lentamente com o processo de modernização e a autonomização de mercadorias. Outro interlocutor, o Sr. Arnaldo, comparou ao período colonial e lembrou do salário que recebia da Companhia Carbonífera: "Era complicado, mas resolvia. Hoje não resolve. E ainda tem que pagar água, tem que pagar luz, tem que pagar alimentação", gastos que naquele período não tinham, mas que tem atualmente e aumenta a necessidade de dinheiro para o consumo.

Tanto no reassentamento Cateme quanto no 25 de setembro, para ter acesso à energia elétrica precisa comprar créditos pré-pagos pelo sistema da CREDELEC, produto que não é vendido em Cateme. Isso significa que para os moradores desse reassentamento comprarem créditos para energia elétrica, precisam ter dinheiro também para o transporte para ir até a vila.

Tendo apresentado o panorama geral dos dois reassentamentos, fazemos o apontamento que nem todos os moradores de Mithethe foram reassentados, pois a área de concessão não abrangeu todo esse bairro. As famílias que não foram reassentadas vivem atualmente bastante próximas da área de exploração mineira e ficaram isoladas. Um interlocutor explicou as dificuldades que elas atravessam diante dessa situação:

Até hoje lá não tem água. Fizeram uma estratégia de levar uma empresa para fazer um furo de água lá, fizeram. Saiu água salgada! Então, vivem ali e nem dá pra ficar aquela gente. Então, levam água para dar para eles. Quando avaria o carro, não há água. Estão a reclamar cada vez mais. Estão lá a sofrer. Estão próximos à mina (Lionel, 2017). 
Isso demonstra que não são apenas os moradores que foram reassentados que tiveram suas práticas alteradas, mas estende-se ao longo do distrito.

Oficialmente, o que a empresa divulga em relatórios é que realiza uma exploração sustentável e em prol da comunidade, mas como é possível realizar exploração mineira sustentável? É atividade que, conforme o próprio RIMA classifica, a maior parte dos impactos são irreversíveis e, de acordo com o que estamos apresentando, as mudanças nas relações sociais dificultam práticas e aparecem para meus interlocutores como uma degradação da vida cotidiana.

A Vale S/A tem um escritório para atendimento aos moradores do distrito, localizado no bairro CARBOMOC, onde está a Casa Quinze. Esse escritório é divulgado como lugar de reclamações para posteriores medidas de compensação e desenvolvimento de projetos para melhorias das condições dos moradores do distrito. No entanto, de acordo com membros das associações, é bastante difícil ser atendido nesse local. Quando estive lá para conhecer os projetos que são desenvolvidos e as reclamações que chegam até esse ponto de atendimento à população, o pedido não foi aceito e foi dada a condição de que precisava de documentos sucintos sobre a finalidade dessa pesquisa e a partir disso iriam avaliar se dariam as informações. $\mathrm{O}$ argumento da funcionária diante dessa solicitação foi que os pesquisadores difamam a empresa e em seguida essa funcionária brasileira argumentou em defesa da empresa, exemplificando com aquilo que compreende como melhoria para as pessoas que vivem nos reassentamentos: antes essas pessoas viviam em casa de pau a pique, agora elas vivem em casa de alvenaria. Um argumento que positiva o processo e tem por base os discursos burgueses sobre o continente que de maneira controversa o coloca como atrasado e como se qualquer ação possa ser benevolente. Demonstrou, portanto, pouca sensibilidade à questões que são colocadas frequentemente pela comunidade.

\subsection{As mulheres dos reassentamentos: "não há machambas"}

Uma questão nos parece importante analisar separadamente está relacionada às mulheres nos reassentamentos. Essa foi uma problemática posta por pessoas entrevistadas, sobretudo dos movimentos sociais, numa fala que não está clara para nós se foi organizada pelos próprios moradores do reassentamento enquanto necessidade de apresentar o problema separadamente ou foi dada por organizações não governamentais 
cuja finalidade está em propor políticas públicas de proteção às mulheres ${ }^{73}$. De qualquer forma, o caminhar da pesquisa nos leva a ter a questão de gênero discutida de forma particular, ao expor diferenças nas formas de socialização entre homens e mulheres.

Enquanto os homens que vivem nos reassentamentos reivindicam muitas das vezes por trabalho, as mulheres apresentam o problema pela perspectiva de que nos reassentamentos não tem machambas e não tem mercado. Conforme argumentamos anteriormente, o trabalho assalariado e a produção nas machambas apareceram como relações complementares na reprodução social das famílias envolvidas e nos parece que a interrupção de uma dessas atividades pode desequilibrar essa relação e assim recai sobre toda a família.

No entanto, ao nos debruçarmos sobre essa problemática, a questão que nos foi colocada é que a perda do acesso à terra fértil e a interrupção das atividades em torno da produção agrícola nas machambas aumentou a violência contra as mulheres. Essa foi uma das conclusões a que chegaram, por exemplo, as pesquisadoras Osório e Silva (2017). Elas argumentam que as mulheres estão numa situação de provedora de comida para as famílias e a impossibilidade de continuar a desempenhar estas funções nos novos locais não apenas se reflecte no quotidiano familiar, como despoleta sobre ela novos focos de violência (OSÓRIO \& SILVA, 2017: 141-142). Nesse sentido, por que e por quem as mulheres são compreendidas como provedora de comida?

Numa exposição etnográfica, o padre Raul Altuna (2014) abordou no livro Cultura Tradicional Bantu, entre outros temas, a divisão do trabalho por sexo. Seus estudos iniciaram nos anos 1960 quando foi à Angola como missionário. Ele argumenta que a divisão do trabalho entre os povos africanos não obedece a instituições, mas estão conforme as características masculinas e femininas. Ele apresenta o homem como caçador, guerreiro, desbravador e justifica que aos homens são atribuídas as características como força física, resistência e coragem, atributos que são apresentados por ele como naturais e como se fossem específicos dos homens! Seguindo na justificativa dessa divisão, Altuna traz o fator biológico como fator que restringiria certas atividades às mulheres e exemplifica pelas seguidas gestações. Ele diz que a maternidade é uma

\footnotetext{
${ }^{73}$ Entre as pesquisas realizadas por organizações não governamentais, temos como referência o livro “Corporações econômicas e expropriação: raparigas, mulheres e comunidades reassentadas no distrito de Moatize", de autoria das professoras Conceição Osório e Teresa Cruz e Silva (2017), cuja pesquisa foi financiada pela União Europeia e publicada pela WLSA, uma organização de mulheres localizada na cidade de Maputo. A pesquisa é baseada em consultas de outras pesquisas já realizadas, análise da legislação e entrevistas com mulheres que vivem em Moatize.
} 
vocação da mulher bantu (idem, 255) e por isso os homens tinham maiores condições de mobilidade. Além disso, apresentou tabus principalmente em relação à menstruação que pesam sobre a mulher e que as transformaram, às vezes, num ser impuro e profanador (idem: 170 e 260).

O padre destacou que as atividades realizadas pelas mulheres africanas que ele observou não são atividades que se restringem ao ambiente privado (ALTUNA, 2014:260) e assim podemos retomar o que apresentamos no capítulo anterior em relação à dissociação entre as mulheres brancas e negras. No contexto em que apresentamos as mulheres negras moçambicanas, elas não estavam confinadas e entediadas em casa como as mulheres brancas que estavam em torno da Casa Quinze e supérfluas nas relações da forma social capitalista. As mulheres negras foram apresentadas pela literatura moçambicana como mulheres sobrecarregadas e que realizavam a maior parte das atividades domésticas no contexto da reprodução das próprias famílias (e sabemos que geralmente levam consigo os filhos, muitas das vezes presos em suas costas com uma capulana), ao passo que os homens negros estavam no trabalho obrigatório pelo regime colonial, em cumprimento à Lei do Indigenato, ou seja, exerciam trabalhos que obedeciam instituições.

No entanto, a ontologização do trabalho e da diferenciação entre as raças e gênero levou Altuna (2014: 170) a definir essas mulheres negras como a agricultura-mãe-esposadona de casa, ou seja, coloca a mulher negra no lugar da reprodução. Roswitha Scholz chama a ontologização das diferenças de culturalização do social. Para ela, a naturalização de um processo não explica a relação assimétrica entre os sexos, "raças" etc. Por isso há de considerar diferentes planos: social-estrutural, individual e o valor dissociação, pois não são meras estruturas, mas também são processos históricos e são dinâmicos.

Dessa maneira, Altuna (2014) parece excluir o processo social que colocou as mulheres nessa situação, pois ainda que ele tenha feito a ponderação de que não se pode dizer que a divisão do trabalho são separações e necessidades que brotam naturalmente, nem que se possa fazer generalizações visto que há "fatores econômicos e as exigências da vida" que também possam determinar essa separação (ALTUNA, 2014:169), o padre não relaciona as relações de trabalho ao processo de expropriação e coerção ao trabalho explicitamente forçado a que foram submetidos os homens durante o regime colonial ${ }^{74}$. A compreensão que temos é que ele mantem um argumento que tira a historicidade do

\footnotetext{
${ }^{74}$ Lembramos que a lei do indigenato também foi aplicada em Angola, área de estudo do padre.
} 
processo e traz um argumento ontológico que posteriormente se põe como tradição. Ou seja, ele formula a partir de uma perspectiva que é entendida como ontológica e a define como cultura, como o próprio título do livro sugere: Cultura Tradicional Bantu.

Nesse sentido, enquanto os homens que vivem nos reassentamentos narraram seus próprios momentos de mobilidade ou de outros homens de sua família, com idas e vindas por causa do trabalho, seja chibalo ou não, ao questionarmos sobre as atividades das mulheres ou onde elas estavam nesses momentos, a resposta predominantemente era que elas estavam na machamba. Lembramos ainda que na pesquisa em campo muitas das vezes era um homem quem respondia pelas mulheres, visto que na maioria das vezes são eles que falam português, resultado do próprio processo de mobilização ao trabalho.

Assim, eles narram que quando estavam no trabalho explicitamente forçado como punição por não terem pago impostos ou quando estavam inseridos na abstração do trabalho em troca de salário na Companhia Carbonífera, no Algodoeiro, ou em outras empresas que poderiam ser até mesmo em outros países, as mulheres estavam na machamba. Enquanto os homens trabalhavam na Carbomoc, ainda que houvesse mulheres trabalhando lá, podemos dizer que as mulheres predominantemente estavam nas machambas. Enquanto os homens estavam nas atividades de olaria, fabricação de móveis, corte de lenha ou trabalhos informais na cidade, as mulheres estavam na machamba. Quando os homens estavam desempregados ou sem realizar as atividades acima citadas, muito provavelmente as mulheres também estavam na machamba. E quando viúvas ou separadas de seus maridos, disseram que também estavam na machamba. A partir disso, um interlocutor homem concluiu: A esposa nunca trabalhou. Na altura não havia necessidade de trabalhar.

Então, voltamo-nos agora para as mulheres no desejo de perceber as particularidades das relações em que elas estão envolvidas. A narrativa colocou o cultivo na machamba como a principal atividade que era realizada pelas mulheres, as mamás ${ }^{75}$. Com base nas formulações de Scholz, compreendemos que não se trata de uma função ontológica em que elas tem vocação para a atividade, mas é resultado do processo histórico da sociedade da mercadoria. No processo de formação das categorias da forma capitalista de produção, o regime colonial colocou os homens negros em mobilização para o trabalho, em grande parte explicitamente forçado, enquanto as mulheres estiveram na produção de alimentos.

\footnotetext{
${ }^{75}$ As mulheres em idade reprodutiva são chamadas de mãe ou mamás, os homens são chamados de pai ou papás, por qualquer pessoa inclusive pessoas que tem a mesma idade se chamam dessa maneira.
} 
Atualmente ao longo do país, inclusive cidades, é possível ver com frequência mulheres em diferentes lugares vendendo produtos das machambas, evidenciando que a relação da produção de alimentos é uma prática corriqueira, mas não apenas a produção para subsistência, pois há a relação da venda. Lembremos ainda que os estudos de Ruth First publicados pelo CEA (1998) já apontaram que a produção das machambas não deveria ser pensada como uma agricultura de subsistência.

Entre Tete e Moatize as mamás vendem em feiras, como a que tem na vila de Moatize às quartas-feiras, nas paragens de $\operatorname{machimbombos}^{76}$, nos mercados populares. Na cidade de Tete tem o mercado Kwachena que tem a mesma forma do mercado Xipamanine de Maputo. O Kwachena é um grande mercado a céu aberto, debaixo do sol de Tete e sobre a terra seca. Muitas pessoas. Em meio a vendedores e compradores há aqueles que oferecem outros serviços, como as crianças que carregam as compras em troca de moedas, os motoristas de tchopela $^{77}$ que oferecem seu serviço motorizado. São maneiras de obter dinheiro.

No mercado Kwachena é possível encontrar alimentos mais baratos do que nos mercados mais modernos, além de roupas e alguns produtos industrializados. Dentre os vestuários estão as capulanas e roupas do tipo calamidades. Essas roupas fazem parte de uma rede internacional, cujas roupas foram doadas por pessoas de variados países para a África. Organizações internacionais fazem a mediação e vendem para pessoas que estão nos países africanos. Após outra intermediação, as roupas são vendidas nas ruas e mercados e com o dinheiro obtido essas pessoas comprarão outras mercadoria. É uma maneira de terem dinheiro quando a necessidade não se resume à roupas e a necessidade da venda da força de trabalho está posta ao mesmo tempo em que não há quem compre, ou seja, não há trabalho. São roupas que foram doadas devido às "calamidades em África" pelos países do centro e formam enormes brechós na periferia do mundo. Os maiores brechós do mundo, mas sem a gourmetização de um brechó da vila Madalena de São Paulo, por exemplo.

Os alimentos vendidos no mercado Kwachena são expostos em barracas ou estendidos no chão sobre capulanas ou esteiras de palha. Sentadas lado a lado no chão, as mamás expõem seus pequenos montinhos de tomate, couve, feijão, batata, tangerina e vendem num ambiente com grande concorrência entre tantas mulheres. Já nas barracas são vendidos carnes de cabrito e peixes do rio Zambeze ou afluentes, como o famoso

\footnotetext{
${ }^{76}$ Paradas de ônibus

${ }^{77}$ Espécie de triciclo motorizado particular. Tuctuc.
} 
peixe chicôa que é um peixe seco, conhecido como o peixe de Tete. São vendidas frutas e legumes sem grande variedade, mas em grande quantidade e esses produtos vendidos nessas barracas aparentemente não são produção própria, mas sim revenda. São vendidas bananas, repolho, muitos repolhos a 5 meticais cada ${ }^{78}$. A origem dessas frutas e verduras vendidas em Moatize, principalmente nas barracas, foi muitas das vezes atribuída à Angônia, um distrito próximo à fronteira com o Malawi.

Há outros tipos de barracas onde se encontra a venda de produtos industrializados, como creme dental, sabão em pó, sabonete, shampoo, salgadinhos, suco em pó. Na cidade de Tete, há ainda o mercado Primeiro de Maio que é semelhante ao Mercado do Povo e ao Mercado Janete que estão em Maputo. Nesses mercados, além da venda de alimentos, roupas das calamidades e produtos industrializados, há a venda de comida pronta preparada pelas mamás: caril $^{79}$, xima ${ }^{80}$, peixes... Aqui retratamos os mercados como lugar possível para as mulheres fazerem negócios ${ }^{81}$.

Minhas interlocutoras apresentaram que em Chipanga e Mithethe as machambas estavam próximas das casas e era uma área fértil por estar na (ou próxima à) várzea do rio Moatize ${ }^{82}$ de onde também coletavam água e por isso, antes de serem reassentadas tinham condições de realizar a prática da machamba. As narrativas apontam que cuidar das machambas ocupava boa parte do dia dessas mulheres e a rotina estava em ir muito cedo para as machambas e retornavam próximo ao horário do almoço. "Machambas grandes, onde dava boa coisa". Em outros dias, iam até a vila ou à cidade para vender produtos das machambas. Ou seja, essas mulheres não estavam restritas ao ambiente doméstico, ainda que a produção de alimentos possa aparecer como uma produção para a família, mas o que parte dessas mulheres dos reassentamentos narram é que elas tinham uma rotina árdua que envolve a produção e venda de alimentos em troca de dinheiro.

Para parte dos meus interlocutores homens, o que aparece é que as mulheres não necessitavam trabalhar e que elas não trabalhavam. Parece que para eles, elas ocupavam a função enquanto reprodutoras, muito próximo do que Altuna (2014) caracterizou como agricultora-mãe-esposa-dona de casa, como uma vocação e como se essas mulheres não estivessem libertas ao trabalho. Aqui compreendemos a libertação para o trabalho com

\footnotetext{
${ }^{78}$ Equivalente a aproximadamente R \$0,25 de acordo com o câmbio de 2017.

${ }^{79}$ Cozidos de verduras ou carnes, cuja base é óleo de coco e amendoim.

${ }^{80}$ Espécie de polenta, feita com farinha de milho branco.

${ }^{81}$ Nos mercados, nas barracas na ruas e paragens dos machibombos foram os lugares onde tive maior aproximação com as mulheres e onde pudemos conversar muitas das vezes sem a interferência de um homem.

${ }^{82}$ Afluente do rio Rovúbwe que por sua vez é afluente do rio Zambeze. Ver anexo II.
} 
base nas formulações de Marx (1986) e Gaudemar (1977) em que o processo de expropriação coloca a necessidade da venda da força de trabalho. Na compreensão desses homens, é como se o trabalho para elas não estivesse autonomizado.

No entanto, ao olharmos para as práticas cotidianas dessas mulheres, percebemos que elas estão sobrecarregadas de atividades tanto no ambiente privado quanto público, realizam as atividades domésticas, mas também atividades que geram dinheiro principalmente em torno das machambas. Assim, temos a tendência em pensar na posição dessas mulheres na reprodução social dessas comunidades mais próximo do sentido que Roswitha Scholz (2017) apresenta como mulheres duplamente socializadas. Roswitha Scholz (2017) elaborou que o processo de modernização coloca as mulheres duplamente socializadas, pois as mulheres são empurradas da esfera reprodutiva para a esfera profissional (mantendo simultaneamente a responsabilidade principal pela esfera da reprodução), ou seja, são responsáveis pelos trabalhos de reprodução que ela chama de trabalhos de amor e ao mesmo tempo necessitam do dinheiro e esse é obtido pelo trabalho.

O processo de deslocamento para os reassentamentos alterou a produção nas machambas e as relações que eram realizadas em torno delas conforme descrevemos. Tais relações não são possíveis de serem reproduzidas nos reassentamentos e assim as mamás argumentam: aqui não há mercado.

Aqui não temos machamba, nem escola, nem campo, nem mercado não temos. Cada um vai lá comprar um cesto de tomate, vender na sua porta assim. Há de haver movimento para acabar o cesto de tomate? Leva muitos dias para acabar um cesto de tomate. (AMÉLIA, 2017)

Quando conseguem produtos para vender, não tem comprador. O dinheiro não circula. No entanto, as atividades que realizavam anteriormente continuam como de responsabilidade das mulheres e muitas das vezes o marido exige que ela o cumpra.

Um homem questionou para as pesquisadoras Osório \& Silva (2017: 142): A mulher tem que ir carregar água, agora eu como homem é que tenho que ir carregar água? Já a interlocutora senhora Amélia, da mesma maneira naturalizando como sua obrigação, compartilhou: A mulher de agora não tem respeito. Como vou ter respeito se esse tempo de ir buscar água, preparar lanche para o marido e não estou na casa. Chega marido e sentar com fome. Não vai me abandonar? Estão a abandonar mesmo (AMÉLIA, 2017). É nesse contexto, que as pesquisadoras Osório \& Silva (2017) formularam que a violência contra as mulheres advém da construção social das identidades que orientam os 
papéis sociais na divisão sexual do trabalho, cujas práticas culturais tem um modelo de dominação. Que é o patriarcado.

A partir disso, mulheres que foram reassentadas tem o tom saudoso em relação aos bairros em que viviam antes de se mudarem para os reassentamentos. Nessa narrativa os antigos bairros aparecem como lugar possível de se reproduzir socialmente e com isso, pode aparecer como se neles não tivessem contradições, mas compreendemos que isso se dá pela comparação ao contexto atual em que as relações estão transformadas e há a impossibilidade da prática das machambas, ou seja, no contexto atual as relações estão em maior nível de degradação e obscurece ou amenizam os problemas anteriores.

No reassentamento 25 de setembro não há área próxima às casas onde possam cultivar as machambas enquanto no reassentamento Cateme o solo é bastante pedregoso, infértil, distante dos vales dos rios.

Hoje quando alguém aqui quer fazer machamba tem que apanhar carro também. Ir lá! Tem que arranjar dinheiro de chapa. Não tenho dinheiro que eu possa ir logo, trabalhar, depois outro dinheiro para voltar e dormir aqui. Lá você tem de arranjar meio de fazer uma palhotinha pra dormir lá mesmo. Tem que ficar uma semana. Aí quando voltar hei de apanhar já janela que não tem: ladrões tiraram (MIRIAM, 2017).

Esse relato demonstra que essas mulheres buscam alternativas para manter a produção na machamba, mas acreditamos que não seja para cumprir uma função como se sentissem menos mulheres com isso, mas por necessidade.

A expropriação aparece para os moradores de Cateme pelo isolamento do reassentamento e a distância de áreas férteis, o que impede a produção, além da distância dos lugares de venda dos produtos e outros possíveis trabalhos informais. Para quem mora no reassentamento 25 de setembro, a expropriação aparece pelo cercamento da área ao redor para a mineração e por não terem área para machamba na área que foi concedida a cada família. Cabe lembrar que foram ainda relatadas dificuldades de encontrar áreas férteis onde não estejam organizadas outras comunidades.

Não são apenas as diferentes características do lugar que interferem na produção e reprodução das famílias. O processo de reassentamento também dividiu os membros da família alargada entre o reassentamento urbano e o rural. A Sra. Miriam, moradora do reassentamento (urbano) 25 de setembro, explicou que ao viver numa casa tanto com os filhos quanto com os pais, ou seja, a família alargada: o filho ia trabalhar, o pai não trabalha. Aquilo que o filho vai ter um pouco, também consegue repartir e dar aos pais. Num prato ou num balde: enche e entrega quando cozinha na panela, todos estão aí a 
servirem-se. Era boa coisa (MIRIAM, 2017). Nesse sentido, homens e mulheres de diferentes gerações compartilhavam o consumo do que vem de uma mesma produção e/ou fonte de renda. E as mulheres, as mamás, também faziam parte dessa composição: nós mesmo que somos mãe, lá em Chipanga ia capinar. Na machamba dava muitas coisas. Essas coisas tavam a beneficiar nossos filhos para estudar ${ }^{83}$ (AMÉLIA, 2017). Ao expor a possibilidade de estudos a partir dos produtos das machambas, coloca a machamba nesse lugar de reprodução de práticas mediadas pelo dinheiro, pois esses produtos eram vendidos, trocados por dinheiro e talvez tanto quanto o que os homens produziam em termos de olaria e marcenaria, por exemplo. Atividades que faziam parte de um circuito para a venda e que estava conectada à vila de Moatize e à cidade de Tete, trabalhos informais autonomizados.

Com o dinheiro que essas mulheres obtinham com a venda dos produtos das machambas, elas poderiam pagar ainda o transporte e outras formas de consumo, ou seja, era possível chegar aos mercados onde acessavam os consumidores daquilo que produziam e, assim, o dinheiro continuava a circular por mais que pudesse não haver acumulação. Nesse panorama percebemos que a atividade da machamba não se encerra na própria machamba e é o meio que permite que essas mulheres reproduzam relações mediadas pelo dinheiro.

No entanto, parte dos homens reassentados dizem que elas não trabalhavam. Por quê?

Aqui é importante dizer que, ainda que os homens realizassem atividades que geram dinheiro, ao questionarmos sobre qual trabalho realizavam, geralmente eles respondiam que não trabalhavam e acreditamos que estavam se referindo ao trabalho formal, com salário frequente. Retomamos que é bastante recente a Lei do Indigenato na qual o Estado colonial proibia a reprodução pela forma e qualidade que definia como vadiagem. Era considerado trabalho quando havia a mediação do Estado ou empresas, quando o trabalho formava valor. Assim, o trabalho aparecia explicitamente como obrigatório, num processo civilizacional do patriarcado produtor de mercadorias. Nesse contexto, os trabalhos domésticos e as machambas para produção de alimento cujo consumo era da família eram práticas realizadas pelas mulheres que não produziam valor, ainda que garantissem as condições para que os homens pudessem retornar para continuar

\footnotetext{
${ }^{83}$ Entre as principais finalidades do dinheiro, além da troca por alimento, sempre foi apresentada à mim, pesquisadora, a necessidade do pagamento da escola para os filhos. Lembramos que a taxa de analfabetismo em Moatize é de 88\% (MAE, 2005).
} 
a vender sua força de trabalho e produzir valor. Seria por esse motivo que o trabalho realizado pelas mulheres não é por eles identificado como trabalho? É por esse motivo que eles não reconhecem seus trabalhos esporádicos e informais enquanto trabalho?

Ao olharmos para as particularidades das relações que estão em torno das machambas e retomamos o processo histórico é que percebemos que essas mulheres quando foram reassentadas já tinham a necessidade do dinheiro e era pela venda de produtos da machamba e outras relações nos mercados que entravam na relação da circulação do dinheiro. Elas tinham o meio de produção e tinham necessidade de dinheiro para a reprodução familiar.

A expansão da mineração intensificou a crise da reprodução social mediada pela forma do dinheiro, pois deu novos passos no processo de expropriação e atualmente o meio de produção nas machambas é tolhido, dificultando a continuidade da prática agrícola que era base da alimentação dessas pessoas e de troca por dinheiro para as mulheres. O processo de modernização torna mais escassas as possibilidades de reprodução ao mesmo tempo em que aumenta a necessidade do dinheiro para comprar, inclusive, o alimento básico, por isso coloca homens e mulheres numa situação de maior instabilidade, com potencial aumento da fome. E segundo meus interlocutores, não há trabalho.

Outro passo no processo de expropriação é a separação das famílias alargadas e a transformação nessa reprodução coletiva. Entre os moradores do 25 de setembro, o reassentamento urbano, em tese o chefe da família nuclear tem trabalho, mas ainda que ele o tivesse, os baixos salários ou mesmo os trabalhos sazonais não são suficientes para a reprodução total dessas famílias. Enquanto no reassentamento Cateme, mulheres solteiras ou viúvas e idosos que foram separados dos outros membros da família são os que menos tem acesso ao trabalho, não falam português e como dissemos, por mais que seja o reassentamento rural, não há possibilidade de desenvolver machambas. Para esse reassentamento foi a maioria das mulheres, até porque, como dissemos a atividade das machambas são realizadas pelas mulheres e esse é o reassentamento rural. Então uma reassentada explicou: a separação que a empresa nos fez, foi por acaso, foi triste para nós. Até hoje é triste. Porque lá tem outras pessoas que estão a viver como velhos, os maridos já morreram, não tem ocupação. A terra não é boa para produção (MIRIAM, 2017). E então ela narra que o processo de divisão das famílias alargadas colocou novas situações cotidianas, como quando os mais velhos adoecem e estão no reassentamento Cateme. Os filhos que estão no 25 de setembro nem sempre podem ir visitá-los e levar 
alimento por falta de dinheiro para transporte. Mesmo visitas rotineiras que gostariam de realizar, já não podem.

A perda da machamba e consequentemente o meio de socialização pela forma mercadoria, acentua a crise em que a mulher negra está posta no processo de modernização.

Muitos homens abandonaram, a mulher ficou sem marido, foram casar outras mulheres. Abandonaram a casa. A mulher está sozinha. Casaram a segunda mulher menina, deixaram a antiga mulher porque já velha. Isso sempre acontecia também, só que lá a mulher não ficava tanto aflita porque lá havia negócio, a mulher ia no mato cortar lenha, carregava na cabeça até o mercado. Iam apanhar malambe ${ }^{84}$, partiam e revendiam. Compravam para fazer aquela coisa tipo iogurte, põe nos plastiquinhos e vai no mercado vender. Voltavam com vassoura, verduras. Lá uma mulher sem marido suportava viver. Aqui não tem ocupação. Não tem. Agora o homem te abandonou e você está sentada em cima das mãos, não tem nenhuma ocupação (MIRIAM, 2017).

O processo expõe essa mulher numa reprodução que é individualizada, não mais familiar, pois, conforme as formulações de Roswitha Scholz (2017), as instituições trabalho e família se desfazem em pequenas autonomias individualizadas, é o asselvajamento do patriarcado (Scholz, 2017). Nesse contexto de catástrofe, as autoras Osório \& Silva (2017) formulam que as formas de violência contra as mulheres aumentaram nos reassentamentos:

O aumento da violência doméstica tem a ver com a imposição de novos elementos no quadro das relações de poder como é o caso do desemprego masculino, a entrega da indemnização aos chefes de família e com a inexistência de terras aráveis onde as mulheres possam produzir para a sobrevivência familiar, de mercados e outras fontes de renda, como esta fala bem descreve:

"Há muita violência doméstica quando a mulher exige dinheiro para comprar comida e roupa para a criança. Em Chipanga não tínhamos tanta violência porque com o dinheiro que a machamba dava podíamos comprar roupa para as crianças. As mulheres não esperavam pelo dinheiro do marido". (OSÓRIO \& SILVA, 2017: 158)

Em relação às mulheres dos reassentamentos é bastante perceptível a ausência de trabalho formal para elas e apontamos ainda que é possível dizer que a maioria dessas mulheres pouco estudaram e uma minoria delas fala português. Então, diferentemente do

${ }^{84}$ Fruto do embondeiro (baobá) 
que observamos e de como a mulher moçambicana aparece na literatura, no contexto dos reassentamentos elas não estão sobrecarregadas de atividades como noutros tempos, pelo contrário nos pareciam e relatavam estar entediadas e sem atividades para realizar durante os dias. Mas diferentemente das mulheres brancas do romance Rainhas da Noite, essas mulheres não estão em relações burguesas com a reprodução realizada por outro.

Osório e Silva concluíram que as mulheres reassentadas estão em situação de agravamento da pobreza, solidão, violência e as recomendações que as autoras fazem diante desse quadro estão no sentido de transformar as mulheres em sujeitos no que chamam de empoderamento pela autonomia econômica com a escolaridade e formação profissional (OSÓRIO e SILVA, 2017: 167-168). E entendemos essa como reivindicação de dignidade humana para as mulheres, ainda que seja sobre a própria humilhação e sem a emancipação das categorias capitalistas, num contexto que entendemos naquilo que Heidemann (2004: 27) chama de dignidade humana secundária. Entendemos que essa reivindicação que as autoras chamam de empoderamento da mulher e que aparece como reivindicação por trabalho possa ser a busca por uma, digamos, redução do dano que o processo de modernização e expropriação causa a elas nessa forma particular.

No entanto, haverá trabalho para elas?

\section{Capítulo 3: Mineradoras multinacionais e capital fictício}

\subsection{A modernização pela forma da cooperação para o desenvolvimento}

No capítulo 2 dessa dissertação apresentamos o contexto interno moçambicano em que se deu as concessões de terra para mineradoras multinacionais explorarem carvão mineral na Província de Tete, mais especificamente no distrito de Moatize. Trata-se de um período de abertura econômica ao capital estrangeiro logo após a assinatura do Acordo de Paz. Mas e o contexto brasileiro, como podemos analisar essa relação?

O período recente das relações do Brasil com o continente africano, o qual inclui o início das atividades de mineração realizada pela Vale S/A em Moçambique, é muitas vezes analisado como um momento de aproximação por cooperação entre os países SulSul e assim foi definido pelo próprio governo brasileiro. O Instituto de Pesquisa Econômica Aplicada (IPEA) realizou um estudo para o Banco Mundial, com dados colhidos entre 2010 e 2011, ano de início das operações da Vale em Moatize, publicado 
com o título Ponte sobre o Atlântico: Brasil e África Subsaariana-Parceria Sul-Sul para o crescimento. Esse estudo expõe a aproximação entre o Brasil e o continente africano que tem como justificativa o pagamento de dívida histórica com a África e para isso sugere arranjos alternativos exemplificados com os BRICS e o Fórum de Diálogo Índia-Brasil— África do Sul (IBAS). Esses arranjos constituiriam novas esferas de articulação, cujos atores emergentes poderiam ser mais ativos (BANDO MUNDIAL \& IPEA, 2011: 15).

De acordo com o relatório, esses arranjos alternativos são uma resposta às análises que tem por base a Teoria da Dependência, em que as relações comerciais entre os países são compreendidas como de exploração dos países centrais aos periféricos. A crítica que teóricos dessa perspectiva apontam é que o subdesenvolvimento não é o estágio preliminar de uma trajetória que levaria ao desenvolvimento, pelo contrário, a relação entre países desenvolvidos e subdesenvolvidos perpetuaria a diferença entre eles. Assim, os países periféricos, do sul, se tornam dependentes dos países centrais, ou seja, dependentes dos países do norte e reféns do mercado internacional (BANCO MUNDIAL \& IPEA, 2011). Nesse sentido, os arranjos alternativos seriam maneira de equiparar os países na sociedade produtora de mercadorias?

A atual forma de reprodução capitalista que é colocada como de cooperação entre os países do sul, incluindo entre Brasil e Moçambique, parece ter um princípio parecido ao que se aplicou nos anos 1970. Naquele período, a proposta para Moçambique formulada pelos sociólogos que apresentamos no capítulo 1 , colocava o enfrentamento à exploração imperialista com o nacionalismo pela mobilização para o trabalho. Nesse novo momento a proposta é colocada como uma política para ampliar as relações comerciais entre os países periféricos, do sul, para romper a dependência em relação aos países centrais, do norte (BANCO MUNDIAL \& IPEA, 2011). Dentro da ideia do que vem a ser a cooperação está a transferência de tecnologia. Essa seria uma medida para superar o atraso na esteira da modernização ao ser um benefício ao pais que recebe por dar condições de, supostamente, competir no mundo da (produção da) mercadoria. Uma análise que não tem crítica ao processo de modernização em si nem à forma capitalista de reprodução. Além disso, outra medida seria empréstimos de dinheiro entre os países do sul, o que adequa-se às novas formas de reprodução do capital cuja acumulação além do lucro, se dá pelos juros.

Os autores do relatório citado apontam que a Teoria da Dependência está alinhada à visão de mundo do ex-presidente brasileiro Luiz Inácio Lula da Silva e o então ministro das relações exteriores Celso Amorim e apontam a importância da diplomacia 
presidencial no processo que então incentivou tais arranjos alternativos (BANCO MUNDIAL \& IPEA, 2011). Dito isso, os autores formulam que a iniciativa de Lula de aproximar as relações de Brasil com a África não apenas buscava construir parcerias estratégicas na região, mas também se relacionava ao compromisso assumido com a população afrodescendente do Brasil (BANCO MUNDIAL \& IPEA, 2011: 43).

A cooperação Sul-Sul é assim apresentada nesse relatório como a criação de uma nova ordem mundial, pela nova dimensão dos sistemas internacionais econômicos, financeiros e comerciais, justificada como uma política estimulada por solidariedade, afinidades histórico-culturais, econômicas e políticas (BANCO MUNDIAL \& IPEA, 2011).

Outro material que consultamos foi produzido pelas jornalista brasileira Amanda Rossi (2015). Durante pesquisa em campo entre 2010 e 2013, a jornalista fez um levantamento das atividades que o Brasil mantinha em Moçambique e publicou no livro “Moçambique, o Brasil é aqui". Ela dividiu essas atividades entre negócios, cooperação e outras atividades (nesse último caso está a Igreja Universal). Nesses conjuntos de atividades a jornalista Rossi colocou como cooperação: o projeto ProSAVANA, a Fiocruz pela fábrica de medicamentos antirretrovirais, parcerias com os ministérios brasileiros: da educação, desenvolvimento agrário, desenvolvimento social e do esporte que realizaram trocas de experiências e tecnologia com os ministérios moçambicanos, dentre outros setores $^{85}$. Já como negócios está a Vale S/A, o Banco Nacional de Desenvolvimento Econômico e Social (BNDES), Banco do Brasil, BRF, dentre outros, além das empreiteiras Odebrecht, Camargo Correa, OAS etc. que a jornalista bem ilustra ao dizer que são empresas satélites principalmente da mineradora Vale S/A, pois é para a exploração do carvão que as empreiteiras realizaram obras de infraestrutura. Foram construídos ou reformados portos, ferrovias, hidrelétricas, aeroporto, ou seja, consolidaram o capital fixo, para a circulação das mercadorias destinadas à exportação. De todos os negócios, a jornalista frisa que a Vale Moçambique desponta em números, tanto em financiamento quanto em produção.

Rossi (2015) separa a apresentação das atividades em grupos por tipos de relações comerciais. Essa separação repetiu-se na própria embaixada brasileira em Maputo, durante entrevista realizada em 2017. Nessa entrevista, um funcionário da embaixada justificou os agrupamentos divididos entre negócios e cooperação, baseando-os na

85 "Segundo a agência brasileira de cooperação (ABC), mais de 70 instituições brasileiras estão envolvidas em projeto de cooperação" (GARCIA \& KATO, 2016: 72) 
(aparente) finalidade da atividade. Se a finalidade for lucro, é negócio. Se não for, é cooperação.

As pesquisadoras brasileiras Garcia e Kato (2016: 69), por sua vez, analisaram a cooperação Sul-Sul a partir do Corredor Logístico de Nacala (CLN) em Moçambique que corresponde à duplicação da ferrovia que conecta Moatize ao Porto de Nacala e o próprio porto. Elas definiram a relação que oficialmente é chamada de cooperação como políticas públicas e interesses privados e fizeram um recorte temporal que inicia em 2003. Com base em Vigevani e Cepaluni, elas argumentam que a expansão das relações entre os países do sul caracteriza a busca de autonomia pela diversificação e essa autonomia resulta da abertura de relações políticas e comerciais com mais parceiros e economias emergentes. Então, tendo por base o relatório do IPEA que mencionamos, somado a outras pesquisas, elas apresentam que os discursos oficiais dividem as atividades em três pilares: investimento, cooperação e financiamentos, onde cooperação corresponde à diplomacia solidária para inclusão social, desenvolvimento agrícola e sustentabilidade. Enquanto investimento seria uma lógica empresarial para a expansão dos negócios pelas empresas com redução de custos e aumento dos lucros (GARCIA \& KATO, 2016: 70). Elas expõem os financiamentos que foram realizados para as atividades, num momento em que o próprio banco BNDES se internacionalizou e destacamos esse ponto, pois é momento em que esse banco estatal empresta capital para além das fronteiras nacionais, principalmente para a área da construção civil. A partir desse contexto, as autoras argumentam que em pesquisa de campo cooperação e investimento se confundem. E concordamos com elas.

Não nos debruçaremos a analisar por atividade mencionada, mas apontamos que as atividades realizadas pela Vale S/A constam no relatório do IPEA e muitas das atividades que aparecem como negócios estão em torno da mineradora, além de algumas atividades que constam como cooperação terem algum tipo de incentivo da empresa. Além disso, a Vale S/A declarou publicamente participação nas discussões sobre o modelo do Acordo de Cooperação e Facilitação de Investimentos (ACFI) assinado em 2015, que volta-se àquilo que foi chamado de cooperação industrial (VALE, 2015).

A justificativa desse Acordo referido é estimular as exportações do Brasil para Moçambique, assim como promover uma integração produtiva entre os países, apresentado na figura de uma relação generosa que representaria laços de amizade e espírito de cooperação. Além de estabelecer as regras na relação, o acordo criou o Comitê Conjunto e Pontos Focais, com a finalidade de serem fomento da governança institucional na matéria, através do estabelecimento de foro específico e de canais técnicos que atuem 
como facilitadores entre os governos e o setor privado, ou seja, foi um momento de personificar os agentes burocratas que lidam com a relação e em contrato estabelecer uma relação juridificada. $\mathrm{O}$ acordo garante ainda que, mais do que ampliar as relações produtivas, essas não sejam menos vantajosas do que as relações que Moçambique mantém ou venha a estabelecer com outros países ou empresários/ conglomerados, conforme consta no acordo ao compactuar que cada parte permitirá aos investidores da outra parte estabelecer investimentos e conduzir negócios em condições não menos favoráveis que as disponíveis para outros investidores estrangeiros (REPÚBLICA FEDERATIVA DO BRASIL, 2015 - grifo nosso).

O acordo contempla as atividades de mineração, energia, investimentos agrícolas e construção civil. No início desse item apresentamos que entre as ações colocadas como da relação Sul-Sul, esteve a construção civil e a infraestrutura nos países africanos foi quantificada pelo IPEA em dados estatísticos antes mesmo de existirem: o custo para corrigir o déficit de infraestrutura da África está estimado em US\$ 75 bilhões e os autores seguem no argumento de que a mobilização financeira tanto do setor público como do setor privado é essencial para o desenvolvimento da infraestrutura (BANCO MUNDIAL \& IPEA, 2011: 24). Então podemos aqui estabelecer relações entre o que é colocado como ajuda para suprir os gargalos na infraestrutura com os financiamentos que foram realizados.

O ACFI aparece sob a perspectiva da cooperação, conforme o próprio título do acordo aponta, e foi a empresa Vale S/A quem mediou a elaboração para facilitar os investimentos. O Acordo coloca-se positivamente ao processo de modernização como propulsor à geração de empregos, redução da pobreza e nesse sentido proporcionariam o desenvolvimento humano, como sinônimo de felicidade. Chamamos atenção do leitor para a positivação do trabalho por esse argumento institucional em que a expansão das atividades é posta como necessária e não considera que o próprio processo cria simultaneamente desempregados ao acentuar processo de expropriação. Ao longo desse capítulo tentaremos demonstrar como o próprio processo incide contraditoriamente nesses mesmo elementos que positiva. Além disso, a abstração que constitui o trabalho é inquestionável e a compreensão que o coloca como necessário naturaliza essa relação, sem importar o que será produzido, nesse caso carvão.

A maneira que o processo é apresentado, sob a justificativa do pagamento da dívida histórica com a intensificação da territorialização do capital no país africano, periga repor a ideia iluminista sobre o continente africano que o apresenta como atrasado. Ao 
justificar esses projetos em África, por exemplo, o ex-presidente Luiz Inácio Lula da Silva argumentou para a jornalista Rossi (2015: 337):

Sou o tipo de político motivado à emoção. E quanto mais eu via essas coisas [pobreza] na África, mais eu sentia que esses países tem tudo para fazer... Vale a pena investir! Eles não tem nada, então qualquer coisa que você faz é muita coisa. $E$, mesmo que o Brasil não tenha todo o dinheiro que a gente queira, o pouco que o Brasil tem, se o Brasil investir, ajuda demais (grifo nosso).

Aqui percebemos um posicionamento contra a desigualdade e o que qualifica a análise em que conclui que "eles não tem nada" é uma concepção moderna que passa pela ideia da mercadoria, própria do mundo moderno.

O filósofo moçambicano Ngoenha (2014: 17), ao criticar a etnografia sobre o continente africano, afirma que há dois imperialismos: o imperialismo mercantil, que se apropria das terras, dos recursos naturais e até mesmo dos homens. Depois, o imperialismo histórico, que se apropria de um novo espaço conceptual: o homem não histórico. O argumento do filósofo está no sentido de que a etnografia coloca povos como exóticos, sem história e teria sido essa a base científica de um processo que fundamenta em parte o dualismo em que coloca oposição entre o civilizado e o bárbaro.

Sendo assim, em que medida essa fala do ex-presidente brasileiro repõe a ideia do homem sem história por não ser propriamente do mundo moderno, do mundo da mercadoria? Ou estaria ele se referindo a homens incluídos no mundo moderno, mas mundo moderno em crise, ou seja, a barbárie? No segundo caso, em que medida a relação apresentada como de cooperação seria potência contra a sociedade em crise?

Mbembe (2001), por sua vez, em seu texto "As formas africanas de autoinscrição" faz crítica à representação do continente africano nas pesquisas que são feitas por não africanos e também às que são feitas por africanos. Para ele, dois discursos essencialistas foram construídos: o nativista (ou metafísica da diferença) e o instrumentalista (ou economicismo). No centro dessas duas correntes ele coloca três eventos históricos: a escravidão, o colonialismo e o apartheid, que promoverem a ideia de que os africanos tornaram-se alienados de si mesmos e que os africanos não tem bens materiais. Uma degradação histórica que teria causado uma morte social. Compreendemos que tal crítica volta-se à consciência que transforma a pessoa em mercadoria, em que o africano aparece 
como alienado de si mesmo e torna-se objeto, coisificado ${ }^{86}$. E é nesse sentido que compreendemos que está a invenção do indígena, que inclusive passou por um amparo científico, criticado por Ngoenha (2014) e também por Sine (1976), pois esse amparo científico deu base à missão civilizatória que pontuou quem estava dentro e fora da forma social para impor o processo de homogeneização das práticas sociais pela imposição da forma capitalista de reprodução. Segundo Costa (2015: 20-21), no caso moçambicano, esse processo teve respaldo de descrições etnográficas para assim subjugá-los ao trabalho explicitamente forçado.

Mbembe (2001: 180) critica ainda a ideia iluminista que coloca o africano como passivo e uma vítima de outros, que legitima o discurso democrático e progressista e se coloca como emancipatório, pois a noção de civilizatório, mesmo sendo recolocada como de progresso, autoriza a distinção entre o não humano e o não suficientemente humano que poderia se tornar humano se lhe fosse dado um treinamento adequado.

O camaronês Nkolo Foé (2013:178), por sua vez, ao escrever sobre os discursos sobre África expõe esse dualismo entre o atraso e o moderno exemplificado com o discurso do ex-presidente francês Nicolas Sarzoky numa universidade no Dakar que diz que: o drama da África é que o homem africano não entrou totalmente na história e ao falar sobre os ciclos agrícolas conclui que nesse imaginário onde tudo recomeça sempre, não há lugar para a aventura humana, nem para a ideia do progresso. Foé compara o discurso de Sarzoky a um discurso de Victor Hugo em 1879 que, da mesma maneira, colocava a África como um continente sem história e em oposição à civilização, classificando o continente como bárbaro e onde todos os homens são feiticeiros (FOÉ,

2013: 179). No entanto, quem estaria enfeitiçado e por qual feitiço? E qual o limite do “eles não tem nada"? Qual o limite dessa benevolência?

\subsection{Uma solução à brasileira: A Vale S/A em Moçambique}

Quando analisada a relação entre Brasil e África pela perspectiva das relações SulSul, em que Moçambique notadamente é nosso interesse, o recorte temporal que se faz é marcadamente após o ano de 2003. No entanto, a exposição que o IPEA faz, joga luz ao período que precede e para pensarmos esse processo foi no livro da jornalista Rossi (2015)

\footnotetext{
${ }^{86} \mathrm{Na}$ tese de Toledo (2008) o escravo-coisa é discutido no sentido que ultrapassa a determinação da forma do pensar do sujeito, mas como relação comercial de venda de escravos, quando a pessoa é igualada à coisa dinheiro na troca (TOLEDO, 2008: 100), assim torna-se mediação social.
} 
que encontramos base para apresentarmos o histórico das relações entre os países em que, somados à revisão bibliográfica que realizamos, podemos perceber que uma mesma intenção apareceu em outros momentos da história dos países e sob diferentes planejamentos estatais.

Baseada em Mazzuchelli \& Oliveira, Leite (2010) apresenta que, na compreensão desses autores, a recessão é resultado de um padrão de acumulação que teria se iniciado nos anos 1950 com o Plano de Metas do governo de Juscelino Kubitshek. O Plano de Metas, teria aumentado a produção de bens de consumo duráveis, resultado das novas condições tecnológicas e de aumento de força de trabalho no Brasil pelo avanço do processo de expropriação. Assim, o aumento de produção somado aos baixos salários culminou nos anos 1960 numa crise de concentração e de realização dos excedentes internos que não podem retornar à circulação internacional do capital-dinheiro (LEITE, 2010:192).

A autora segue o argumento de que, durante o período ditatorial no Brasil, a política de recessão organizou um processo de concentração de capitais que os autores Mazuzuchelli \& Oliveira apresentaram como momento de formação da fase monopolista do capitalismo no Brasil, cuja reforma fiscal teria promovido políticas de incentivos fiscais e criou uma nova forma do capital financeiro, administrada pelo Estado, entrando no mercado de capitais. A autora formula como momento de instauração nacional das bases do capital fictício ${ }^{87}$ (LEITE, 2010: 193).

Em processo, os baixos salários e o aumento da produtividade mencionados do período anterior resultaram em excedente de mercadorias caracterizadas como bens não duráveis que o mercado interno não era capaz de consumir, ou seja, no mercado interno foi esgotada uma determinada fase de valorização no Brasil. Nesse sentido, para lidar com a crise, o Estado brasileiro adquiriu empréstimos com os EUA para investir na indústria e na construção civil, esse último marcadamente como uma estratégia keynesiana em que possibilita salário sem produzir mais mercadorias.

Nesse mesmo período, o Estado brasileiro governado pela ultradireita se aproximou do Estado moçambicano, socialista. Rossi (2015: 90) diz que foi um escândalo diplomático, pois a princípio o regime militar brasileiro apoiava o governo português de Salazar e após a independência de Moçambique houve um esforço do governo brasileiro

\footnotetext{
${ }^{87}$ Kurz define que o capital é fictício em sentido estrito quando o malogro do processo substancial de valorização é maquilhado, pagando-se créditos que se tornaram malparados com novos créditos (KURZ, 1995).
} 
em demonstrar que havia mudado de posição e estava contra ao colonialismo. Por esse motivo a FRELIMO teria alegado que não poderia aceitar a proposta brasileira porque as mentes e os corações moçambicanos, depois de sofrerem quatorze anos de guerra, de verem durante todo esse tempo o Brasil apoiando Portugal, não estavam acostumados a considerar o Brasil um país amigo (ROSSI, 2015: 77). A jornalista diz que situação mudou quando, estrategicamente, Geisel faz do Brasil o primeiro país a reconhecer a independência de Angola e, nas palavras de Rossi, conquistando Angola e Moçambique (idem: 79), apaziguando a relação. Noutra perspectiva, podemos dizer que eram dois países de governo centralizador, nacionalista, cuja economia era administrada pelo Estado, Estados militarizados. No entanto, não simultâneos no processo de modernização.

Nessa altura, o Estado brasileiro realizou empréstimos pelo Banco do Brasil ao Estado moçambicano para que o país africano pudesse comprar mercadorias das próprias indústrias brasileiras. Entre as mercadorias estavam locomotivas, tratores, barcos, aviões e livros didáticos (ROSSI, 2015: 84). Tal relação permitia a circulação das mercadorias e a realização do valor nelas contido com a compra. Ao mesmo tempo o Estado credor acumulava pelos juros do empréstimo. De acordo com Rossi (2015), a intenção em aumentar as exportações das indústrias brasileiras para Moçambique se deu principalmente durante o governo de Figueiredo, nos anos 1980, ou seja, quando a terceira revolução industrial causou um salto na produtividade.

Acreditamos que no período que estamos tratando já havia interesse do governo brasileiro na produção por commodities em Moçambique, tanto na exploração mineral quanto no agronegócio, pois o Brasil, inclusive, participou do processo de estudos de viabilidade no processo de modernização da mineração em Moatize e lembramos que nesse período a exploração era feita pela CARBOMOC. Além disso, a crise do petróleo após a Guerra do Ramadão colocava o carvão mineral como uma mercadoria alternativa ${ }^{88}$

É nesse período que o economista Samir Amin (1978: 32) formulou que tanto o fim do colonialismo nos países africanos quanto o fim do socialismo foram momentos de renovação da aliança de classes entre o capital dos monopólios e as burguesias locais. Para ele, o conteúdo do neoimperialismo está associado ao desenvolvimento das técnicas

\footnotetext{
${ }^{88}$ Conhecida também como a guerra do Yon Kippur. A intensificação da produção de carvão em Moçambique era dúvida para o governo socialista de Moçambique por dois motivos: faltava capital e materiais para investir na produção de carvão e também havia incerteza de compradores para a quantidade de carvão que seria produzido. A oscilação do preço da mercadoria no mercado internacional dependia do preço do petróleo, pois o carvão era alternativa quando havia alta no preço do petróleo (SECH, 1984: 15; $25)$.
} 
produtivas, por isso concluiu que não se pode comparar a produtividade das indústrias "clássicas" localizadas na periferia e a das "novas" indústrias concentradas no centro. Nessa perspectiva (centro-periferia), o autor formula que:

Os países sub-imperialistas importariam capitais e tecnologia do centro, exportariam os produtos das indústrias "clássicas", principalmente para o centro, acessoriamente para as zonas da periferia mais desprovidas, e, com estes meios, cobririam os pagamentos que deviam ao centro a título de capital e tecnologia importados. A concentração das indústrias "clássicas" nestes países em conjunto com a elevada taxa de exploração do seu proletariado, permitiriam às burguesias sub-imperialistas beneficiar de uma fracção do excedente suficiente para assegurar o equilíbrio econômico e político do sistema (AMIN, 1978: 30)

O que Samir Amin (1978) não cogitou nessa formulação foi o não pagamento dos empréstimos pelos países da periferia aos países ditos sub imperialistas, exatamente por não terem meios de o fazerem, pois ao não produzir, não tem lucro para pagar juros. E o saldo desse imbróglio de países em diferentes momentos do processo de modernização foi uma dívida do Brasil com os EUA e de Moçambique com o Brasil. São países não simultâneos no processo de modernização que, quando na posição de devedor na relação, não realizaram o fim em si da valorização do valor emprestado, pois essa seria realizada com a venda de mercadorias e com o lucro poderiam pagar os juros do empréstimo. Nesse sentido, Moçambique não pagou a dívida para o Brasil. Assim como o Brasil não pagou a dívida aos EUA. Não necessariamente que uma relação seja consequência da outra.

Nessa relação, o Brasil pode ser entendido como sub imperialista, conforme a formulação de Amin (1978), pois transita entre devedor e em processo de modernização retardatária em relação aos EUA, e credor em relação a Moçambique que se encontra atrás nessa esteira da modernização.

A dívida que Moçambique contraiu com o Brasil nesse período foi pauta durante o governo do presidente Fernando Henrique Cardoso que em 2000 propôs o perdão. Nesse mesmo período esteve a política de privatizações com a abertura para o capital estrangeiro de algumas estatais e uma delas foi a Companhia Vale do Rio Doce que foi privatizada em 1997 entrando no mercado de ações. A privatização aparece sob a justificativa de que o desempenho econômico das empresas estatais estava fraco, que o governo não tinha possibilidade de maiores transferências de recursos e por isso havia a necessidade de iniciar um processo de privatização (VALE, 2012, 217). A abertura para o capital privado rompeu o monopólio estatal e fragmentou as ações da empresa, tornando-a uma 
multinacional. A privatização fortaleceu grupos, formando uma fusão de indústrias, bancos e o próprio Estado. Entre os principais acionistas atualmente estão a Litel, Bradespar (do Banco Bradesco), Mitsui\&Co e BNDESPar.

Lembramos que no fim dos anos 1990 Moçambique encontrava-se em processo de reestruturação. O Acordo de Paz de 1992 oficializou (em tese) o fim da guerra civil, também chamada de agressão externa. Com a crise que, nesse caso aparece como do socialismo, o país abriu-se para o capital estrangeiro e o Estado mudou de função, deixando de ter monopólio sobre as empresas. Esse processo mostra que mais do que o capital personificado em classes, conforme formulou Amin (1978), para continuar o processo de valorização o próprio capital se transforma.

Kurz (2015: 39), ao analisar o processo de valorização do valor, afirma que cada vez que se esgota uma determinada fase de valorização, também as instituições, os conceitos e as ideologias políticas que a ela se encontram associados se tornam obsoletos. Nesse sentido, com o processo que afinal é marcado como de abertura econômica, Moçambique adequa-se à padronização de relação social em que são os Estados Unidos que conduzem as leis desse sistema mundial.

No relatório do Banco Mundial e IPEA (2011), os autores formularam que a nova África coincide com o Brasil global ao analisarem essa relação no início dos anos 2000. Nessa caracterização, o continente é apresentado como de oportunidades e que está em rápida transformação. Além disso, os pesquisadores argumentam que países do continente passaram por reformas políticas e atualmente são democráticos.

O Brasil global que atua nesse novo Moçambique é apresentado pelo Banco Mundial \& IPEA (2011) como um país benevolente, que teve sucesso em reduzir a desigualdade social e teve uma experiência de desenvolvimento. Sendo assim, teria lições a oferecer aos países africanos no desejo de apoiar e participar do desenvolvimento, pois considera que as capacidades institucionais dos países africanos são deficientes, os países tem ainda gargalos de infraestrutura, dentre outras necessidades.

Nessa perspectiva que coloca o governo brasileiro benevolente na relação, Garcia, Kato \& Fontes (2013: 8) lembram o artigo de Celso Amorim do período em que ele diz que:

Lula revelou-se o mais africano dos presidentes. Pediu perdão pelos crimes de escravidão, visitou duas dezenas de países e abriu caminho para as ações de cooperação e negócios. Segundo o ex-chanceler, o Brasil seria visto por diversos países do continente como um modelo a ser seguido, afirmando que para cada problema africano existe uma solução brasileira. 
Qual é esse problema e problema para quem? E qual a solução? De um lado, o Brasil é entendido como o país que tem a contribuir positivamente no processo de modernização do continente africano, por outro, a nova África é apresentada como a nova fronteira para os que buscam parcerias e mercados (BANCO MUNDIAL \& IPEA, 2011: 2). Nessa relação que aparece como amigável, de cooperação, a dívida de Moçambique foi renegociada em 2004 pelo Estado brasileiro, durante o governo Lula (BANCO MUNDIAL \& IPEA, 2001; Rossi, 2015: 90) ${ }^{89}$ e de Joaquim Chissano em Moçambique. Esse mesmo ano, foi quando iniciou o processo de expansão da exploração de minérios pela Companhia Vale do Rio Doce na África e é nesse processo de territorialização da empresa em outros países que, em 2007, o nome da empresa mudou para apenas "Vale".

No contrato com a mineradora Vale S/A, ao Estado moçambicano foi garantida a entrada de dinheiro: Fica reservado a favor do Estado Moçambicano uma participação gratuita correspondente a cinco por cento (5\%) do capital social da Concessionária (REPÚBLICA DE MOÇAMBIQUE, 2007). Isso resulta que a exploração dos recursos naturais é maneira de arrecadar dinheiro pelo Estado moçambicano.

A empresa multinacional tem sede no Brasil e o Estado brasileiro, personificado na figura do ex-presidente brasileiro Luiz Inácio Lula da Silva (2003-2011), mediou as negociações da empresa junto ao Estado moçambicano, personificados primeiramente pelo ex-presidente Joaquim Chissano, seguido por Armando Guebuza. Esses por sua vez concederam a entrada das empresas. Com a ida da Vale S/A para Moçambique para a expansão da exploração do carvão mineral foi aberta também a fronteira para outras empresas brasileiras atuarem no país africano. A jornalista Rossi (2005) argumenta que o ex-presidente brasileiro foi central e o populismo dele essencial na aproximação entre os governos e as empresas. Ao ser entrevistado pela jornalista, o ex-presidente brasileiro questionou: Para que serve o governo senão pra isso?

Nesse contexto, o ex-presidente Lula explicou que a renegociação da dívida foi uma estratégia em que liberamos as pessoas (Estado) para fazerem novas dívidas. É apenas isso. Eles não iam pagar porque não tinham dinheiro (ROSSI, 2015: 143). E assim, a expansão do crédito, característica do governo petista, é regularizada para o país africano para que voltassem a consumir, mas mais do que isso, para que tivessem meios de pagar obras em infraestrutura etc.

\footnotetext{
${ }^{89} \mathrm{O}$ ex-presidente Lula explicou que foi uma estratégia em que "liberamos as pessoas para fazerem novas dívidas. É apenas isso. Eles não iam pagar porque não tinham dinheiro" (ROSSI, 2015: 143).
} 
E assim como ocorreu nos anos 1970-1980, o ex-presidente brasileiro analisou esse novo momento de modernização brasileiro e moçambicano:

Se o Brasil quiser ir para a África, o Brasil tem que financiar as empresas brasileiras a irem para a África. Como os americanos financiaram as empresas americanas a virem pra cá, como os ingleses financiaram empresas para virem construir ferrovia aqui. Sabe, é assim. É assim ou não tem. (LULA em ROSSI, 2015: 352)

Os bancos brasileiros financiaram a ida das empresas brasileiras para o continente africano. Os empréstimos foram realizados para Moçambique por bancos estatais (Banco do Brasil ${ }^{90}$ e BNDES). Essa é a forma de acumulação pela transformação de dinheiro em mais dinheiro, ou seja, o dinheiro acrescido de juros. Para esses projetos em específico, houve contrapartidas para o caso de os juros não serem pagos. Em Angola, por exemplo, foram feitos empréstimos tendo como garantia o petróleo (conta-petróleo). Os empréstimos para o então Projeto Vale Moatize foram realizados pelo BNDES, pela sulafricana IDC e pelo IFC, esse vinculado ao Banco Mundial (Mosca \& Selemane, 2011: 20). Em relação aos empréstimos realizados pelo Estado brasileiro, Rossi (2015: 146-147) argumentou que houve a tentativa de colocar como garantia os royalties do carvão a serem pagos pela Vale (conta-carvão). No entanto, como os royalties ${ }^{97}$ são muito abaixo do que o valor emprestado, pois equivalem a apenas $3 \%$ do valor do minério retirado, vendido ou não (REPÚBLICA DE MOÇAMBIQUE, 2007), não restaria à Moçambique nenhum valor daquilo que foi produzido com a mineração por parte da Vale S/A. Por fim cada obra financiada passou a ter uma garantia própria, baseada na renda futura e paga socialmente.

O Banco Mundial \& IPEA (2011) sustentam em sua análise que África é uma nova fronteira. Tal análise nos remete ao que o geógrafo David Harvey chamou de ajustes espaciais. Para Harvey (2005), o ajuste espacial é maneira de desbravar novos ramos produtivos para manutenção do sistema. Nesse sentido, em períodos de superprodução de mercadoria e superacumulação de capital faz-se necessária essa expansão geográfica para buscar novas áreas de investimentos, novos mercados consumidores e tarefas produtivas para excedente de força de trabalho. Harvey (2005) baseia sua formulação tanto em Rosa Luxemburgo quanto em Lênin e o sentido da superacumulação é tanto em mercadoria,

\footnotetext{
${ }^{90}$ Pelo Proex. O Proex financiamento é o principal instrumento público de apoio às exportações brasileiras de bens e serviços criado em 1991, com recursos financeiros obtidos junto ao Tesouro Nacional. ${ }^{97} \mathrm{De}$ acordo com telegrama que Rossi teve acesso diz que "seriam 425 milhões de dólares ao longo de 35 anos de vida útil da mina, uma média de 12 milhões de dólares por ano. Nada mais" (ROSSI, 2015: 119). No entanto, é duvidoso se considera as oscilações do preço das commodities no mercado internacional.
} 
inclusive a força de trabalho, quanto em capital. Então tanto pela necessidade de buscar novos consumidores para o consumo da mercadoria excedente, quanto na necessidade do capitalista monopolista ampliar suas áreas de investimento para acumulação há a prática da expansão geográfica da atuação e assim, nessa maneira de lidar com possíveis crises entendidas como cíclicas, o ajuste espacial contrabalancearia e o mercado voltaria ao equilíbrio. O processo de expansão geográfica da área de atuação, ou seja, a expansão de fronteira e a territorialização do capital, também por vezes é chamado de globalização ou internacionalização. Essa relação só é possível pela não simultaneidade, nesse caso entre dois países, e por ser uma relação desigual pode ser compreendida por alguns autores como neocolonização.

Se por um lado a relação entre Brasil e Moçambique é posta como cooperação e uma possibilidade de igualar os países no processo de modernização, por outro lado o processo pode indicar que seja próprio do sistema para evitar uma crise. Ou adiar. Assim, o ex-presidente Lula argumentou:

Eu penso que a África poderia ser uma das soluções para a crise mundial. Eu disse isso já em 2008. Uma das formas de você resolver uma crise econômica de magnitude dessa de 2008 - em que você tinha uma dificuldade enorme de consumo nas grandes potências - era você incentivar o consumo nos países que precisavam se desenvolver. E fazer isso financiando o acesso a tecnologias que eles não tem. (LULA em ROSSI, 2015: 341-342)

Essa estratégia só é possível pela não simultaneidade entre os países no processo de modernização, pois ao Moçambique não ter a tecnologia, nem a força de trabalho qualificada de acordo com o desenvolvimento das forças produtivas dos países centrais, o Brasil pode exportar força de trabalho brasileira para trabalhar no país africano, maquinários, dentre outras mercadorias, além do capital investido que retornaria com os juros. Essa não simultaneidade que possibilita isso, é contraditoriamente o que a própria Teoria da Dependência crítica e que dá base à cooperação Sul-Sul. Assim, o ex-presidente brasileiro segue:

Quando eu dizia em 2012 que o Brasil tinha que ter política de Ministério de Exterior como se fosse um mascate, é porque mascate não vende nada na avenida Paulista, ele vende em Itaquera. Ele vende em Santo Amaro. Ele vende na periferia. Onde o Brasil tem mais competitividade hoje? (LULA em ROSSI, 2015: 353)

Nesse sentido, o ex-presidente não coloca o Brasil como uma periferia tanto quanto Moçambique, não são iguais por serem do sul. E lembramos que a Vale S/A foi a 
primeira multinacional a iniciar a exploração mineral em Moçambique nessa nova escala de produção no país e abriu fronteira para outras empresas que Rossi (2015) chamou de empresas satélites.

Então a finalidade da atividade mineira em Moçambique pode ser pensada pelo controle da mercadoria carvão e assim um possível controle especulativo no mercado internacional e, ao mesmo tempo, por ser uma relação permeada por empréstimos. É a expansão do sistema de crédito e a expansão daquilo que Roswitha Scholz (2016) chamou de antecipação do trabalho futuro, pois é com o trabalho futuro que Moçambique pagará a dívida.

Percebemos, assim, que a lógica que orientou as relações entre Brasil e Moçambique que apresentamos do período de crise dos anos 1970-80, à qual mencionamos anteriormente com a definição do que Samir Amin (1978) chamou de sub imperialismo, manteve-se nos anos 2000 e com pretensões maiores ${ }^{91}$. Garcia \& Kato (2013:83) concluem que o Brasil se encontra diante de profundo dilema entre ser “explorador" e "explorado", num interior cinzento que não é centro nem periferia.

Compreendemos que essa forma aparente justifica a forma de reprodução do capital financeiro contemporâneo. O que aparece é colocado como um processo de reparação pelo sistema colonial, marcado na história do Brasil em referência à África, no entanto as formas de reprodução do capital eram outras. Essa aparência esconde a sua essência da relação: o "pagamento dessa dívida histórica" é com cobrança de juros pelos bancos estatais brasileiros, resultado de empréstimos.

\subsection{Período (da ilusão) do boom das matérias primas}

A expansão da fronteira de acumulação para a África não foi estratégia apenas do governo brasileiro e das empresas cuja sede está no Brasil. Já citamos anteriormente que os países que compõem os BRICS e IBAS, que muitas vezes também são colocados no contexto da cooperação Sul-Sul, estavam tanto quanto o Brasil em busca de novas áreas para acumulação. Podemos dizer que nos anos 2000, além do Brasil, outros países voltaram-se para Moçambique como a Índia, China e Japão, por exemplo. Esse não foi um interesse inédito no continente, mas foi momento de nova forma de reprodução das

\footnotetext{
${ }^{91} \mathrm{O}$ relatório do IPEA apresenta que em 2011 a Vale S/A tinha escritórios não apenas em Moçambique como também na África do Sul, Angola, Gabão, Guiné Bissau e República Democrática do Congo. E empresas de mineração, além de Moçambique, na África do Sul, República Democrática do Congo e Zambia explorando cobre e cobalto.
} 
relações capitalistas com o país africano, em que, para o capital financeiro expandir fronteiras, faz pela financeirização da produção de commodities: agronegócio ${ }^{92}$, mineração, além da construção civil.

Em 2011, os pesquisadores moçambicanos Mosca \& Selemane publicaram o resultado de uma pesquisa sobre a abertura da exploração mineral para multinacionais na Província de Tete e relataram incentivos fiscais no setor mineiro e as vantagens que essas mineradoras tiveram em isenções aduaneiras e redução de impostos ${ }^{93}$ naquele que foi o período de expansão da exploração do carvão em Moçambique. O período iniciou em 2004 com a mineradora Vale S/A, com processos de licenças de pesquisa, estudos de impacto e por fim o contrato de concessão da área a ser explorada, seguido pelos reassentamentos das pessoas que viviam nessa área.

Esse período pode ser compreendido como o período (da ilusão) ${ }^{94}$ do boom de matérias primas e, como já dissemos, a expansão das concessões em Moçambique foram internamente chamadas de megaprojetos (MOSCA \& SELEMANE, 2011). Dois termos que trazem a ideia de velocidade/ expansão e tamanho.

Em Moçambique há carvão metalúrgico utilizado na fabricação de aço e carvão térmico utilizado para gerar calor e energia em usinas termelétricas, por isso é mercadoria que teve crescente consumo pelos países chamados de emergentes, ou ainda em processo de expropriação com a expansão industrial e/ou urbana, além dos países que já utilizam há mais tempo o carvão ou mercadorias que dele resultam ${ }^{95}$. O carvão é a principal fonte de energia elétrica do mundo. Entre os principais compradores do carvão de Moçambique atualmente estão a Índia, África do Sul e China, países que compõem o BRICS (OBSERVADOR, 2018).

A área de concessão da Vale S/A em Moçambique equivale a 23.780 hectares (REPÚBLICA DE MOÇAMBIQUE, 2007). Outra mineradora que teve concessão é a anglo-australiana Riversdale Mining Lda que passou a explorar no distrito logo em

\footnotetext{
${ }^{92}$ No caso brasileiro o agronegócio é representado pelo Projeto ProSAVANA, numa parceria com o governo japonês e a Embrapa; a mineração pela empresa Vale S/A e em torno dessas atividades há a construção de infraestrutura para comportar a produção e circulação das mercadorias produzidas. Fizeram parte dessas relações grandes empreiteiras brasileiras.

${ }^{93}$ Sobre o processo de pesquisa, eles apresentam a dificuldade ao acesso à informação e concluem que: ou os dirigentes não tem as informações sistematizadas, ou há uma recusa ao debate ou ainda os funcionários tem medo de represálias (MOSCA \& SELEMANE, 2011: 16).

${ }^{94}$ Em referência ao artigo de Robert Kurz: A ilusão do boom das matérias primas. Disponível em: http://www.obeco-online.org/rkurz191.htm

${ }^{95}$ Com base num estudo divulgado pela World Resources Institute a Revista Exame publicou em 2016 os principais países com instalação de usinas a carvão: China, EUA, Índia, Rússia, Alemanha, África do Sul, Japão, Polônia, Austrália, Coreia do Sul.
} 
seguida e, considerando as áreas distribuídas em diferentes distritos, a área concedida pelo Estado moçambicano à Riversdale soma um total de imensos 127.900 hectares (MOSCA \& SELEMANE, 2011: 22).

A Vale S/A iniciou a extração do carvão em 2011, mesmo ano que a Riversdale foi comprada pela também australiana Rio Tinto num preço considerado inflacionado e num processo sem a mediação do Estado moçambicano na transferência da concessão de terras (idem: 28). Em 2012 a terceira grande mineradora iniciou a exploração na Província pela indiana Jindal Steel and Power Limited, cuja área de exploração está no distrito de Marara, bastante próximo de Moatize.

A extração do carvão por essas multinacionais é realizada a céu aberto, por isso vem a necessidade de reassentar quem vivia nessas áreas de concessão e a paisagem que resulta é bastante horrorosa. No entanto, a mineradora Jindal ainda não reassentou as pessoas que vivem na área que lhe foi concedida pelo Estado moçambicano e explora o carvão em meio às pessoas que vivem na área, a comunidade de Cassoca. Em 2018 a ordem dos advogados de Moçambique interferiu juridicamente para que a mineradora realize o reassentamento num prazo até meados de 2019. O argumento da empresa por não ter reassentado até então é que se você olhar para um mapa, há tantas concessões à volta da nossa, não há espaço [para o reassentamento] (HRW, 2013 :81). Aqui lembramos os projetos piramidais a que Kurz (2016) chamou de elefantes brancos, que deslocam as populações locais pelo desenvolvimentismo e para ele essa é uma das pragas apocalípticas do sistema global capitalista.

No Anexo IV apresentamos a imagem recente que retrata as áreas destinadas à pesquisa e possíveis novas concessões para exploração na Província de Tete. Entendemos que a abrangência e quantidades de licença de prospecção e pesquisa possa demonstrar como o Estado moçambicano parece estar disposto à novas concessões e contratos, por esse ser um dos poucos ramos de negócios que possibilita a entrada de dinheiro no país. Considerando as concessões já ativas e as que estão em processo de estudos, conforme a imagem em anexo revela e tendo em vista que a exploração é a céu aberto, questionamos para onde seriam reassentadas todas as pessoas que atualmente vivem nessas áreas?

Além das grandes mineradoras citadas, há ainda as menores Minas Moatize e Minas Revuboe. A última tinha previsão de reassentar em 2018 a comunidade que vive na área de concessão, no entanto ainda não ocorreu e quando foi realizada a pesquisa de campo em 2017, os membros das associações não tinham conhecimento da área para onde iriam ser reassentadas essas famílias de modo que eles pudessem dar apoio. Então, à 
medida que são feitas concessões, aumenta o problema dos reassentamentos e a dificuldade de acesso à terra.

As modernas forças produtivas dessas grandes mineradoras impulsionaram a produtividade do carvão, tomaram enormes áreas, mas demonstraram que a capacidade de escoamento em Moçambique não correspondia à capacidade de produção das mercadorias, são os gargalos em infraestrutura, conforme consta no relatório do IPEA. Nesse sentido, em 2012 foi iniciada a construção do Corredor Logístico de Nacala (CLN).

O CLN consistiu na expansão da ferrovia para conectar Moatize ao novo porto de águas profundas de Nacala, onde é possível atracar navios de maior porte, diferenciandose assim do porto da Beira que era utilizado até então, cujo acesso era pela linha de Sena que foi construída com base na produção da Companhia Carbonífera, quando a extração se dava em galerias e manualmente, evidentemente em menor escala. O CLN foi construído sob a justificativa de redução dos gastos com transporte e para acelerar a circulação da mercadoria carvão.

A ferrovia atravessa o país vizinho Malawi e por isso fez-se necessário, inclusive, a conciliação entre Moçambique e Malawi que guardavam estranhamentos de longa data, ao menos desde o período em que o presidente Kamuzu Banda governou, entre 1966 e 1994. No fim do período da colonização em Moçambique, os portugueses não queriam aproximações dos moçambicanos com o Malawi pelas ideias nacionalistas e anticolonialistas que cresciam naquele país, pois poderia fortalecer o movimento de libertação em Moçambique. Após a libertação de Moçambique, os países vizinhos continuaram não tendo boa relação, pois diferentemente de Moçambique, o Malawi teve apoio dos países capitalistas e Kamuzu Banda era anticomunista, ou seja, contrário à FRELIMO daquela altura. Um de meus interlocutores que trabalhou no processo de reassentamento para a empresa Diagonal em Moatize, também trabalhou no Malawi com a mesma empresa e relatou contrastes entre os países na representação do Estado. De acordo com ele, foram processos bastante diferentes e no Malawi a atuação do Estado foi mais ausente do que em Moçambique: o governo do Malawi não decidiu nada. Era a Diagonal e a população que decidia o procedimento, sem a intervenção do Estado. Mas ele avalia que foi melhor, pois em Moçambique a negociação foi entre o Estado e a Vale, a Diagonal apenas informava à população. Ao fim da construção do empreendimento, a Vale S/A agradeceu a cooperação tanto do governo de Moçambique quanto do Malawi pelos enquadramentos legais que permitiram os negócios.

Então, trazemos uma parte da entrevista que Mia Couto concedeu à Rossi: 
Eu acho que há empresas - não vou dar o nome - que também não ajudam. Porque acham que o que funcionou no Brasil funciona aqui. Por exemplo, eu tive na mão inquéritos que empresas brasileiras fizeram para reconhecer a realidade social de Moçambique e que eram tirados copy and paste do que faziam no Brasil. Então o inquérito tinha: "Qual é o povo indígena a que você pertence?", "Você tem alguma referência com quilombola?”. Foi preciso chamar atenção, dizer “Olha, mas porque [essas perguntas]?” Há uma certa leviandade. Não perceber que este mundo, apesar de tudo, é um outro. E não é o fato de termos a mesma língua, compartilharmos afinidades históricas, cultural e política que também eu chego ao Brasil e vou fazer coisas que não posso (COUTO em ROSSI, 2015: 362).

Essa exposição de Couto confronta a ideia da relação das proximidades históricas e culturais, ao mostrar que o trabalho feito em gabinete e no Brasil não condiz com as práticas contemporâneas em Moçambique. São duas realidades distintas.

A construção do CLN, feita inicialmente pelas empreiteiras Odebrecht e Camargo Correa, parecia uma boa ideia para empresários como, por exemplo, Miguel Peres, da Odebrecht. Em 2013 ele expressou seu contentamento à jornalista Rossi (2015: 48):

Esse país [Moçambique] evoluiu muito rápido. Daqui a quatro anos a gente não vai reconhecer. Você viu o investimento da Vale em Nacala. Há dois anos, o porto era um fantasma. Hoje está lotado. É impressionante o que aconteceu e o que vai acontecer daqui pra frente.

Nessa perspectiva é como se a produção fosse aumentar ad infinitum. E se retomarmos a imagem das concessões, poderíamos considerar que sim.

A expansão da ferrovia e a construção do porto de Nacala foi uma parceria público privada (PPP) em que a Vale S/A se sobressaiu no consórcio que envolve várias concessionárias e sociedades. Garcia \& Kato explicam que:

Os trechos que exigiam a construção de ferrovias ficaram a cargo da concessionária Corredor Logístico Integrado do Norte (CLIN) que é uma joint venture detida em $\underline{80 \%}$ pela Vale e $20 \%$ pela estatal Caminhos de Ferro de Moçambique (CFM). Na parte de recuperação da ferrovia, a concessionária é o Corredor de Desenvolvimento do Norte (CDN) que é controlada em 51\% pela Sociedade de Desenvolvimento do Corredor do Norte (SDCN) - na qual a Vale tem $85 \%$ e investidores nacionais moçambicanos $15 \%$ - e a Caminhos de Ferro de Moçambique 49\%. Essa concessionária controla também o Porto de Nacala (GARCIA \& KATO, 2016: 76 - grifo nosso).

Isso significa que a Vale S/A e o Estado moçambicano (CFM) investiram mais dinheiro no capital constante do empreendimento. No período de entrada da mineradora 
em Moçambique o capital monetário era de origem de bancos brasileiros, conforme mostrou Rossi (2015). Para a construção do CLN, diferentemente, o capital monetário foi declarado pela mineradora como de origem principalmente do Japão ${ }^{96}$. Ou seja, o crédito já não é do país sub imperialista e aqui podemos lembrar a interrupção de empréstimos realizados pelo BNDES dada as investigações que ocorreram no período. Nesse sentido, a Vale S/A e o Estado moçambicano voltam-se à um país central, o Japão.

Essa nova dívida gerada será paga pela empresa (capital funcionante, nos termos de Marx $^{97}$ ) num período de 14 anos com recursos provenientes da tarifa relacionada aos serviços de transporte de carvão e aos serviços de carga geral fornecidos pelo CLN (VALE, 2018). O que compreendemos como uma dívida que será paga socialmente ao compor o valor das mercadorias que circulam pela ferrovia e porto, principalmente o carvão. Sendo assim, o pagamento dos juros do empréstimo sai do valor da mercadoria produzida pelo capitalista funcionante e por isso o carvão precisa ser útil e ser comprado, pois o valor da mercadoria só se realiza com a compra dela.

No entanto, a partir de 2014 o cenário mudou. Primeiramente a Rio Tinto vendeu a mina para o grupo Internacional Coal Ventures Private Limited (ICVL), um consórcio indiano, por um preço bem abaixo daquele que comprou (DW, 2014). No mesmo ano, a Vale iniciou um processo de vendas de ativos no chamado Programa de Desinvestimento com a finalidade de reduzir sua dívida. A Vale vendeu $50 \%$ da fatia de $70 \%$ que tinha do Corredor Logístico de Nacala e 15\% das minas de carvão para a japonesa Mitsui (que por sua vez também tem ações da Vale S/A), sugerindo que o boom das matérias primas tenha sido de fato uma ilusão.

Isso significa que num curto período, podemos dizer que em torno de 10 anos, foi de grande movimentação entre concessões e transferência de concessões que colocaram em circulação muito dinheiro e também dívidas entre empresas e Estados. E, retomando a imagem IV em anexo, iremos ver que são poucos contratos firmados se comparados ao que o Estado parece disposto a fechar negócio. As áreas que representam contratos de exploração são dessas mineradoras que citamos e foram firmados antes de 2014.

\footnotetext{
${ }^{96}$ Japan Bank for International Cooperation (JBIC); Nippon Export and Investment Insurance (NEXI), que representa as seguintes instituições: Sumitomo Mitsui Banking Corporation; The Bank of Tokyo Mitsubishi UFJ Ltd; Mizuho Bank Limited; Sumitomo Mitsui Trust Bank Limited; Nippon Life Insurance Company e Standard Chartered Ban; Export Credit Insurance of South Africa Limited (ECIC), que representa as seguintes instituições: ABSA Bank Limited; Investec Bank Limited; Rand Merchant Bank e The Standard Bank of South Africa Limited; African Development Bank (AfDB) (Vale, 2018).

${ }^{97}$ Organizamos a apresentação desse raciocínio com base no capítulo XXIII d'O Capital, de Marx, onde o autor discute sobre a autonomização dos juros.
} 
Os países sede dessas mineradoras são os mesmos países que seriam a nova ordem mundial, nos termos do Banco Mundial e IPEA (2011), ou ainda os países sub imperialistas no termo de Amin (1978), países que buscavam novas áreas de produtividade para o ajuste espacial, mas afinal é um país do centro, nesse caso o Japão, que parece re-monopolizar os ativos do setor.

Para alguns, o motivo da venda das concessões ou de parte delas foi em consequência do período de baixa do preço do carvão e o alto custo da produção, o que resultaria em prejuízo para as multinacionais. A promessa do Corredor de Nacala em reduzir os custos não parecia o suficiente (DW, 2014).

O motivo da baixa do preço do carvão pode aparecer como resultado de o Estado chinês ter adotado uma política de redução da poluição para cumprir acordos internacionais em relação às mudanças climáticas, pois o carvão é tido como o principal responsável por emissões de gases que causariam o efeito estufa. Nesse sentido, o consumo do carvão dependeria do inverno chinês que é período de maior poluição e restrição ao consumo do minério. Sendo assim, o período de inverno é apontado como o período de aumento de estoque e diminuição do preço.

No entanto, ao pensarmos pela totalidade da sociedade produtora de mercadorias, percebemos que de forma sistemática a produção na indústria chinesa sofreu uma queda nos últimos anos, principalmente após o colapso nos Estados Unidos da América que despontou a crise em 2008. A crise desacelerou a economia da China por ter provocado a diminuição do consumo das mercadorias produzidas pela indústria chinesa. Isso resultou no aumento de oferta da mercadoria carvão, visto que a China era grande consumidora, e assim consolidou-se o fim do boom das commodities. Ou seja, não é exatamente culpa da política de restrição durante o inverno chinês e a sazonalidade imposta ao mercado.

Nesse sentido, podemos dizer que a expansão geográfica para realizar o ajuste espacial e conter superprodução ou superacumulação conforme formula Harvey parece não ser suficiente, pois o aumento da produtividade não é necessariamente a expansão do consumo e não é necessariamente expansão do fim em si da valorização do valor, pois a mercadoria realiza o valor apenas se for útil para outro, caso contrário será dívida. E como dissemos, há o período de recessão global.

O capital realmente produtor de mercadorias suga por assim dizer o seu próprio futuro (fictício), prolongando assim num meta nível a sua vida, para lá do limite interno já visível. Este mecanismo só funciona enquanto o modo de produção continua a expandir-se (como foi o caso até ao último terço do século XX) e apenas na medida em que a massa de valor futuro ficticiamente 
antecipada se realizar efectivamente, ao menos em escala suficiente para pagar os juros dos créditos. (KURZ, 1995)

Ou seja, o processo leva à expansão da dívida ${ }^{98}$, pois nem sempre os juros são pagos e cada vez mais empresas e Estados estão endividados.

Em pesquisa de campo foi relatado anda que o Estado moçambicano não tem o controle da quantidade de carvão que é extraído, vendido e consequentemente da parte do lucro que lhe cabe, conforme movimentos sociais denunciaram, e acreditam que seja "injusto" que a empresa assuma o comando da produção. Então, a contradição do processo de modernização aparece como problema de gestão, uma crítica voltada aos administradores, sejam nacionais ou internacionais e não há totalidade do processo que se desenrola.

O problema que surge aqui é, porém muito mais complicado do que parece nos diversos discursos sobre a "Justiça", os quais muitas vezes supõem que aos países pobres seja subtraída uma parte da "sua" produção de valor, através talvez de pressões políticas, etc. Na verdade, é a própria "igualdade" do parâmetro de valor que faz com que os países capitalistas com pouco capital possam apropriar-se duma massa relativamente menor de valor em relação a países com muito capital. (KURZ, 1995)

Assim, a crítica do valor é central para compreender a contradição do processo e os limites e barreiras internas do capital e que a contradição não é necessariamente um problema de gestão e o limite não é necessariamente no plano ecológico, por exemplo, tal qual pode parecer quando olhamos para a imagem das áreas de concessões. O limite está nas próprias relações econômicas.

\footnotetext{
98 Para compreendermos a abstração desse processo, tornou para mim mais fácil ao co-relacionar ao processo de uma pirâmide financeira. Para ter o retorno do dinheiro, sempre se deve incluir mais pessoas. São relações que tem base apenas com a mediação do dinheiro, sem mercadoria.
} 


\title{
Capítulo 4: Desenvolvimento das forças produtivas e crise do trabalho
}

\author{
4.1. O desenvolvimento das forças produtivas e o trabalho \\ especializado
}

Neste capítulo voltamos para as particularidades dos trabalhadores de Moatize por meio dos interlocutores em pesquisa de campo e em seu contexto mais contemporâneo.

Em Moatize a estação de trem está no centro do distrito. Atrás da linha férrea há um morro onde está o bairro Seis. Nele há casas de alvenaria construídas dispersamente sobre aquele solo exposto e pedregoso, há pouco verde, há muito calor. Há crianças que brincam entre as casas, adultos que circulam, homens e mulheres em frente às suas casas em suas atividades cotidianas. Ao fazer esse trajeto foi possível ver o limite do bairro com a área da mineração concedida à empresa Vale S/A, marcado por uma grade. Ao subir o morro, no alto do bairro Seis, meu interlocutor e guia nesse caminho, apontou a imensa área que corresponde à Vale S/A e atrás de um outro morro apontou a área que atribuiu à Riversdale, mesmo esta concessão já tendo sido vendida à Rio Tinto e depois para a chinesa ICVL.

Desse mirante, o que mais chamava atenção são as diferenças na paisagem entre o bairro Seis e a área de concessão de onde se extraem o carvão.

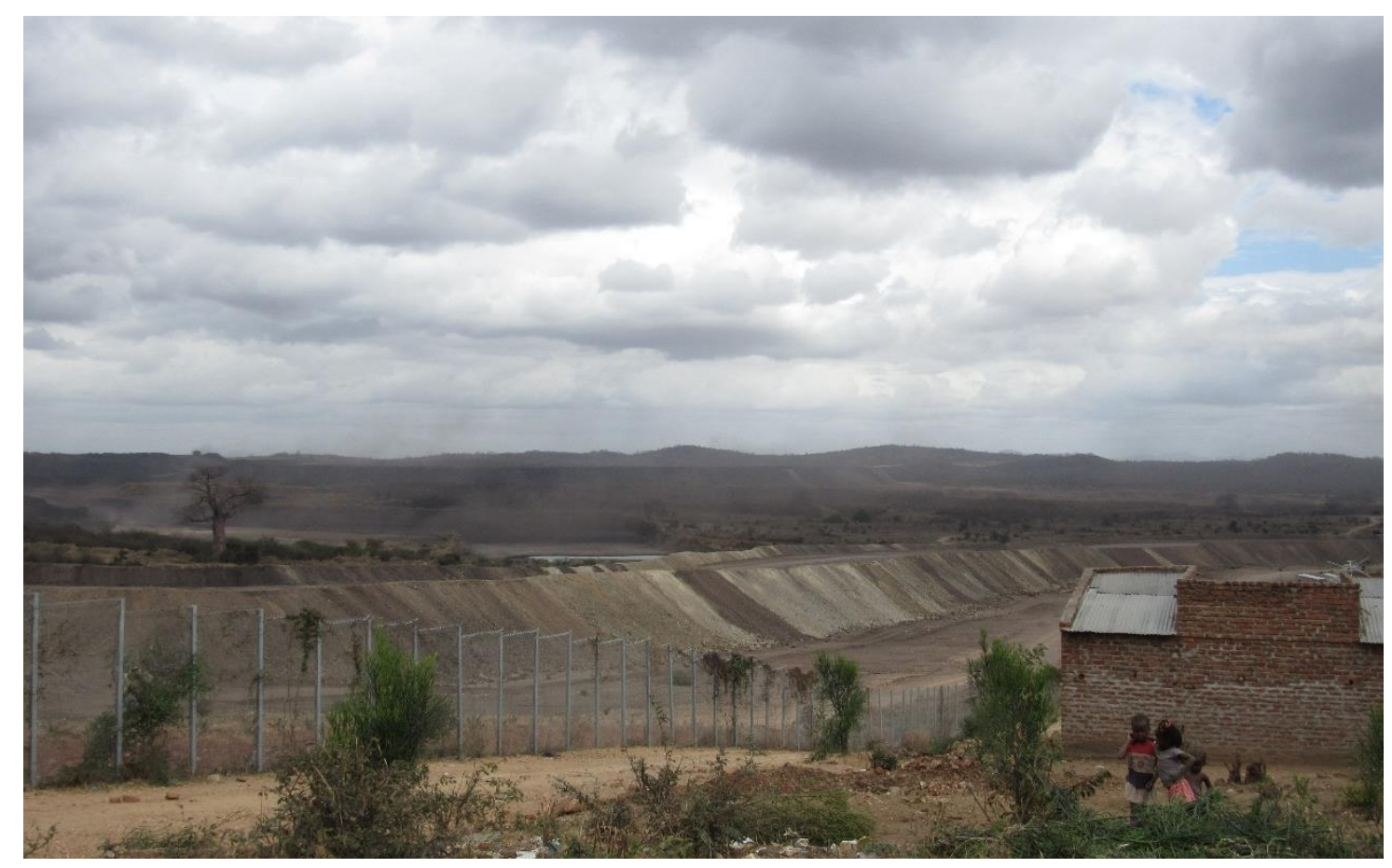

Figura 9: Limite entre o bairro 6 e a área de exploração da VALE Moçambique. Fonte: Viviane Alves Vieira - 2017 
De um lado, a paisagem é monótona, envolvida por um pó cinza que sobe depois de todo o solo ter sido retirado e o carvão remexido. Uma imensa área onde quase não se vê pessoas, há alguns embondeiros ${ }^{99}$ mantidos em meio ao carvão, máquinas maningue big $^{100}$, algumas delas se movimentam, outras assustadoramente ficam paralisadas e destacam-se naquela imensidão sem cor até onde os olhos já não alcançam.

Para o lado do bairro Seis, o pó cinza é espalhado pelo vento sobre as casas e pessoas que nele vivem, o que faz com que alguns dos interlocutores da pesquisa reivindiquem que essas famílias também sejam reassentadas por já apresentarem problemas de saúde e que atribuem a responsabilidade à mineração. Outras comunidades que vivem próximas às áreas de concessão vivem os mesmos problemas decorrentes da poluição em suas variadas formas, além de outras dificuldades que esse imenso vizinho impõe. Entre essas comunidades está parte da comunidade Mithethe que não foi reassentada. $\mathrm{O}$ interlocutor aponta Mithethe, numa direção que contorna essa imensa área da Vale S/A que, inclusive, já engoliu onde ficava o antigo bairro Chipanga.

A questão que colocamos nesse momento é: onde estão e quem são as pessoas que trabalham nessa imensa operação realizada com as máquinas mais modernas do setor da mineração?

A pesquisa em campo revelou que, com a expansão das atividades da mineradora em Moçambique, houve a exportação de máquinas para esse novo padrão de produção visto que Moçambique não realizava a extração do carvão nas condições e proporções atuais, ou seja, o país não tinha a técnica e nem os trabalhadores especializados que tivessem o conhecimento e domínio dessa técnica para a produção. Podemos dizer que ao menos inicialmente foi significativa a mobilização de trabalho estrangeiro para Moçambique, e mais especificamente para Tete, principalmente de brasileiros. São pessoas que foram contratadas diretamente pela mineradora ou ainda para trabalharem numa das tantas empresas terceirizadas que prestam serviços para a Vale S/A.

De acordo com Fernando Raice, secretário do Sindicato Nacional dos Trabalhadores da Indústria de Construção Civil, Madeiras e Minas de Tete (SINTICIM) 64 empresas (consideradas as empresas que tem mais de 10 trabalhadores) prestam

\footnotetext{
99 Árvores do tipo baobá

${ }^{100}$ Máquinas muito grandes. Foi assim que um interlocutor qualificou utilizando três idiomas numa mesma expressão.
} 
serviços para a multinacional, ou seja, são terceirizadas. Essas empresas são brasileiras, sul-africanas, zimbabuanas ou da capital moçambicana Maputo.

O secretário do sindicato apresentou a relação conflituosa em torno das empresas, pois, de acordo com ele, essas empresas terceirizadas tem marcadamente condições de trabalho mais problemáticas do que as condições de trabalho das pessoas que são contratadas diretamente pela Vale S/A. Esse é efeito próprio do processo de terceirização do trabalho: os principais problemas que chegam ao Sindicato estão relacionadas à essas empresas subcontratadas e se forem problemas avaliados como graves, elas serão denunciadas e poderão ser substituídas rapidamente por outra empresa do mesmo segmento sem paralisar as atividades da Vale S/A. Consequentemente pode provocar maior rotatividade de trabalhadores que tem contratos de trabalho de curta duração.

Além disso, Raice afirmou que a principal reclamação que chega até ele está relacionada ao salário: há pessoas que exercem a mesma atividade, mas tem salários diferentes. Ele explicou que essa diferença é feita sobretudo entre quem é migrante e quem não é. Ao contrário do que o leitor possa pensar a partir da experiência em outros lugares, nesse cenário o migrante não recebe menos, ele recebe mais, pois trata-se de uma mobilização de trabalho que tem a qualidade de ser um trabalhador considerado especializado em detrimento da força de trabalho local. Nesse sentido, a diferença salarial é justificada como benefícios e auxílios que as empresas oferecem a esses trabalhadores, uma justificativa que aparece como benevolente ao serem pessoas que supostamente deixaram o conforto de suas casas ou até mesmo do país para irem prestar serviço em Tete, no continente africano. Para um burguês esclarecido essa mudança pode parecer uma relação sacrificial e, nesse sentido, justo receber mais do que os outros trabalhadores.

Além da diferença salarial entre quem é imigrante e quem não é, Raice expôs que há grande diferença salarial entre os trabalhadores da Vale S/A e os trabalhadores das empresas terceirizadas, pois quem trabalha nas empresas terceirizadas não tem as regalias que a Vale S/A oferece. Raice revelou que houve período em que a empresa pagava até $16^{\circ}$ salário, o que ele classificou como um imã que atraiu brasileiros para Moçambique. A partir desse panorama, o secretário do sindicato afirmou que a diferença salarial era tamanha e chegou um momento em que na balança da folha de pagamento 5 brasileiros pesarem mais do que 100 trabalhadores moçambicanos (RAICE, 2017).

Além desse fator colocado como de atração, interessa-nos pensar o fator de repulsão desses trabalhadores que tornaram-se imigrantes. Como seriam as condições de 
vida deles no Brasil? Infelizmente dentro dos objetivos de pesquisa, condições e tempo para realizá-la não incluímos essa questão, mas deixamos esse apontamento.

O processo de terceirização demonstra a autonomização de setores produtivos por especialização de técnicas e a energia que o sujeito automático emprega é numa pequena parte do que é produzido, potencializando a abstração do trabalho e seu fim em si mesmo. Trata-se de um processo que coloca uma relação de distanciamento da força de trabalho da totalidade do processo produtivo e da própria empresa central, nesse caso a Vale S/A. No cotidiano de trabalho na mineração em Tete, a relação entre os trabalhadores é mediada pelas empresas terceirizadas que tem suas próprias relações de hierarquia e gestão. Isso faz com que o trabalhador, por mais que realize sua atividade na área da empresa Vale S/A, não seja funcionário diretamente dela.

No entanto, o processo mantém-se em movimento e com o passar do tempo o salário e o que é posto como benefícios que a Vale S/A pagava aos imigrantes foram sendo cortados. Meu interlocutor do sindicato pontua: com a crise cortaram essas regalias. Em diferentes momentos no trabalho de campo em Tete, meus interlocutores se referiam aos brasileiros como um fenômeno do passado, pois foi quando, de acordo com eles, os brasileiros estavam em Tete. O que argumentam é que com a construção do Corredor Logístico de Nacala (CLN) é possível que atualmente tenha mais brasileiros em Nacala do que em Tete.

A pesquisa em campo revelou que os trabalhadores especializados brasileiros foram em parte sendo sistematicamente substituídos por trabalhadores moçambicanos, pois com o tempo esses tornaram-se relativamente especializados ${ }^{101}$. No entanto, não são moçambicanos necessariamente da Província de Tete.

Em Moatize conheci Márcio. Ele é moçambicano, nascido em Maputo e atualmente trabalha na Vale S/A. Ele contou que no tempo difícil de Moçambique, que compreendo como o período da guerra, ele e sua mãe foram para Cape Town, na África do Sul. O pai já era falecido. Ele disse que era bem jovem quando eles migraram. Lá a mãe trabalhava como doméstica, ele estudava e fez até a $10^{\text {a }}$ classe. Depois abriram um internet café. No entanto, com o tempo ele percebeu que o ambiente na África do Sul era bem hostil para ele, por ser negro e a África do Sul atravessava o regime do Apartheid. Por causa do racismo sul-africano ele voltou para Moçambique, num momento em que

${ }^{101}$ De acordo com João Feijó, a própria Vale investiu na especialização de trabalhadores moçambicanos em formação realizada no Brasil (FEIJÓ, 2016: 11). Essa informação também foi apresentada por Fernando Raice, funcionário do sindicato. 
considera que o país estava economicamente melhor. Em Maputo ele trabalhou em diferentes funções, sobretudo em muitos trabalhos informais. Então conheceu um brasileiro que viu o seu esforço e decidiu ajudá-lo. Eles conheceram-se numa empresa que aluga equipamentos pesados e presta serviços na área de construção civil, inclusive minas. Em 2014, Márcio foi convidado para trabalhar na Vale S/A em Tete. A princípio a função dele seria de tradutor e observou: Vocês brasileiros não sabem falar inglês. Além de falar inglês, ele fala nyungwe, changana e o português. Depois de migrar para Tete, ele contou que concluiu a $12^{\mathrm{a}}$ classe com a ajuda desse mesmo brasileiro e em seguida, ao ser avaliado como capacitado foi promovido para operador e agora trabalha diretamente nas minas. No entanto, no percurso dessa promoção, ele explicou que era momento em que havia uma situação de crise e a Vale S/A precisava diminuir o salário dos operadores, com isso ele "aceitou" o salário menor, se comparado ao salário dos trabalhadores anteriores.

No processo de substituição da força de trabalho imigrante pela força de trabalho migrante ou ainda de morador local, o secretário do sindicato com quem conversei disse que o salário foi de fato reduzido e a justificativa esteve no sentido de que um trabalhador local não precisa dos benefícios que um migrante estrangeiro necessita, como auxílio moradia, por exemplo, dentre tantos outros. Para esses migrantes moçambicanos ou ainda dos países fronteiriços, foi construído um condomínio. No entanto, para viver nele devem pagar aluguel e o que era benefício para os estrangeiros, passa a ser custo para os moçambicanos.

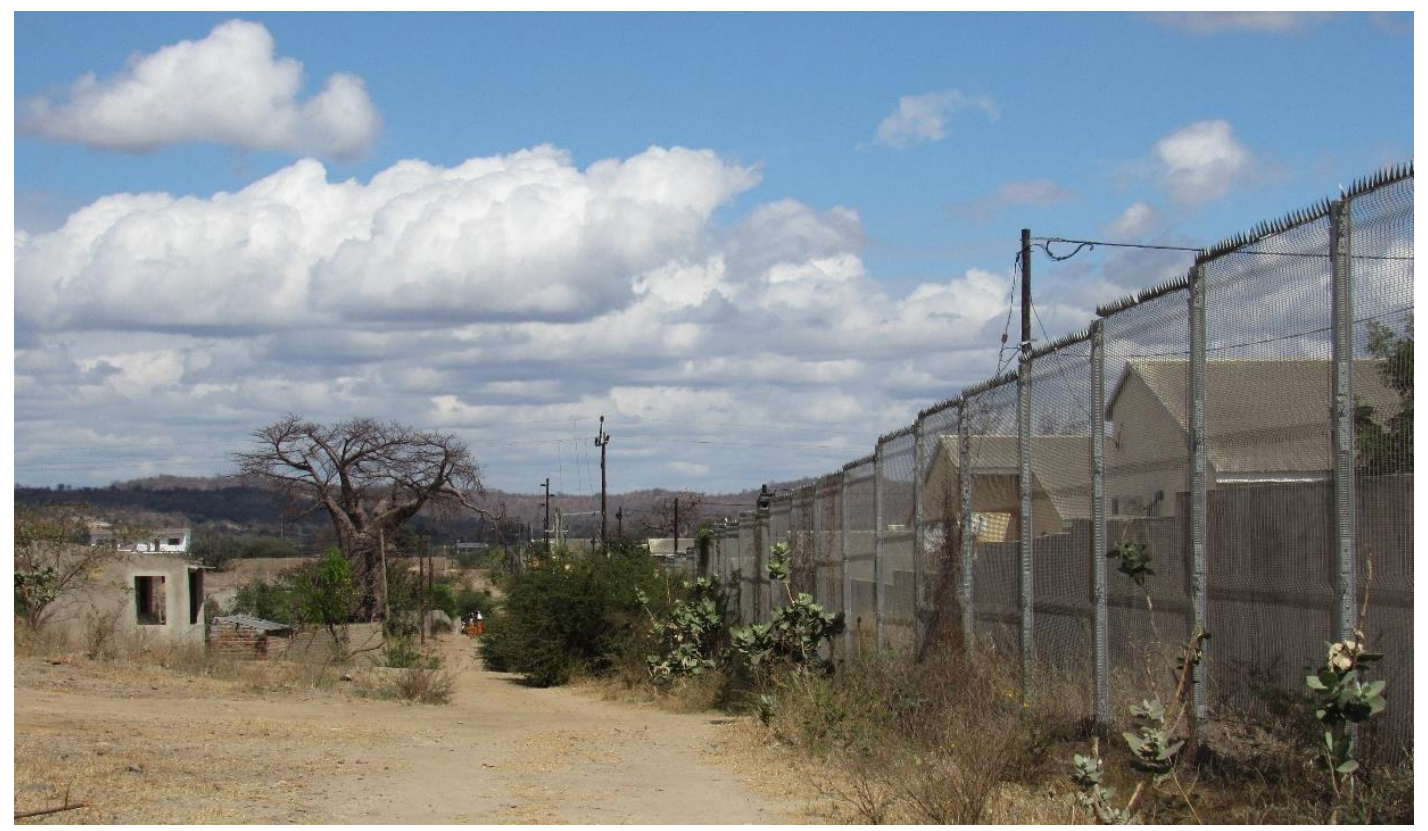

Figura 10: Limite entre o reassentamento 25 de setembro e o condomínio dos funcionários. Fonte: Viviane Alves Vieira - 2017 
Esse condomínio está ao lado do reassentamento 25 de setembro, cuja arquitetura e condição de ambas as instalações destoam na paisagem, materializando as diferenças entre quem é funcionário da empresa e quem foi reassentado.

E quanto aos moradores dos reassentamentos? Voltemos aos ex-mineiros e seus familiares que são os antigos moradores dos bairros Chipanga e Mithethe.

Fagundes é morador do reassentamento Cateme, único falante de português na família. Conversei com ele em meio a vizinhas, filhos, sua mãe, seu pai e um vizinho que foi tradutor nessa conversa nos momentos em que foi necessário. Fagundes relatou que quando a Diagonal fez a reunião em Chipanga durante o processo de reassentamento, falaram: todos vão trabalhar na Vale S/A. Vencimento mínimo 7 paus. Aí muita gente pensou: até o meio do ano sou patrão! Mas quando foram contratados não foi 7 paus. Foi 2200, um salário mínimo ${ }^{102}$. Muitos dos homens atuais moradores dos reassentamentos trabalharam na etapa de abertura da área em que foram construídas as minas e na construção dos reassentamentos, realizado pelas empresas Odebrecht e a Ceta Engenharia e Construção ${ }^{103}$. Essa fala de Sr. Fagundes coloca a expectativa em relação ao salário que as pessoas que foram reassentadas iriam receber em troca da venda da força de trabalho e ele segue descrevendo a diferença salarial que percebeu quando era funcionário das construtoras e estava na relação:

A diferença era a seguinte: vinha motorista da Beira, vinha motorista de Maputo, de Tete e o salário não era o mesmo. Aquele era motorista e aquele era motorista, mas o salário era diferente. Então perguntaram porquê? Esse é moçambicano e eu sou moçambicano (FAGUNDES, 2017).

O relato expõe a dissociação entre pessoas que vivem no mesmo lugar, mas consomem e socializam diferentemente. O que aparece tanto no relato de Fagundes, quanto no que Raice é como se a desigualdade do salário fosse justificada pela nacionalidade do trabalhador. Ainda que as empresas contratem moçambicanos, esses são das principais cidades do país e poucos são de Moatize o que pode ser quase um estrangeiro. Talvez seja por essa aparência que alguns moradores dos reassentamentos

102 Consultando o câmbio de outubro de 2008 (fonte: http://www.bancomoc.mz/FILES/DES/NOTICIAS 29.10.2008.pdf), que está no período de construção dos reassentamentos, temos que 1 dólar correspondia a 24 meticais. No mesmo período 1 dólar correspondia a $\mathrm{R} \$ 2,17$. Isso significa que o salário de 2200 meticais que era o salário de quem vive atualmente nos reassentamentos e que trabalhou na Odebrecht correspondia a aproximadamente 90 dólares, ou a aproximadamente R $\$ 200$. E então, não é difícil imaginar que pode ter ocorrido de 1 brasileiro ganhar mais do que 100 moçambicanos.

${ }^{103}$ Empresa criada nos anos 1980, no período de reconstrução nacional moçambicana. Foi privatizada em 1999 tornando-se uma sociedade anônima. 
acreditam que os problemas que atravessam, desde as casas terem sido construídas precariamente até a não contratação deles para os postos de trabalho, é por serem africanos e por isso ficaram surpresos ao serem informados de que semelhantes problemas causados pelas empresas ocorrem no Brasil.

A igualdade formal entre as pessoas na sociedade capitalista é o trabalho, a venda da força de trabalho. Segundo o Grupo Krisis, a lógica da irracionalidade do trabalho já foi aceita, assim, é o trabalho que coloca em igualdade pessoas em processos sociais diferentes, e por isso não brigam mais sobre se cada vez mais pessoas são empurradas para o abismo e excluídas da participação social, mas apenas sobre como impor a seleção (Grupo Krisis, 1999).

A seleção foi revelada ao fim do contrato desses homens que trabalharam na Odebrecht e Ceta. Eles acreditavam que teriam trabalho e salário durante todo o período de contrato da empresa no distrito, ou seja, enquanto a Vale S/A estiver explorando carvão em Tete, o que não ocorreu. Esses homens que são moradores dos reassentamentos foram dispensados após o término da etapa de implantação do projeto e não foram mais contratados. A partir disso, entre os interlocutores da pesquisa uma queixa é frequente: para entrar na competição por vagas de trabalho, a empresa Vale S/A coloca como exigência um mínimo de estudos que corresponde à $12^{\mathrm{a}}$ classe, caso contrário o trabalhador não é considerado qualificado e está supérfluo na relação, quando necessita do salário, sobretudo quando já não tem mais acesso à terra fértil onde a família possa desenvolver machamba.

O pai de Fagundes trabalhou forçadamente na Companhia e aposentou trabalhando na CARBOMOC. Então Fagundes faz a comparação:

Hoje não é trabalho forçado, já é uma melhoria para o que está a produzir. Para nós é um juramento. Para entrar no trabalho tem que jurar. Se fosse subterrâneo aí tinha muitas pessoas, já o trabalho nas máquinas são pessoas diferentes. É melhoração. Melhoraram! As coisas são assim, mas o nosso sentimento é que deviam nos levar também. Nós não conhecemos a máquina, mas tem outro trabalho. Mas até para esse outro trabalho tem que ter a $12^{\mathrm{a}}$. Para você trabalhar na Vale S/A precisa da $12^{\mathrm{a}}$. Eu não tenho a $12^{\mathrm{a}}$. (FAGUNDES, 2017).

Quem conhece a máquina é o diferente, o estrangeiro, o trabalhador especializado. No livro Com todo valor ao colapso, Robert Kurz (2004) formula que o desenvolvimento das técnicas produtivas, ao mesmo tempo em que aumenta a quantidade de mercadorias 
produzidas num menor tempo, torna necessário menos trabalhadores no processo produtivo. Menos trabalhadores e os trabalhadores necessários devem ser especializados.

Assim, Fagundes traçou o processo de modernização do setor. Partindo do período em que a mobilização para o trabalho era explicitamente forçada juridicamente, como atravessou seu pai e tantos outros homens que trabalharam nas galerias subterrâneas. A humilhação (Heidemann, 2004) acometia essas pessoas que eram transformadas em mero material do processo de valorização. Na forma de reprodução atual, os trabalhadores não são mais explicitamente obrigados (chibalo) por terem a necessidade do trabalho, ou seja, estarem expropriados.

Diante dos tantos trabalhadores livres, não há mais a necessidade de o trabalho ser explicitamente forçado e as empresas podem selecionar o trabalhador. Isso se dá pelo próprio processo de expropriação que coloca as pessoas livres para vender sua força de trabalho e tem necessidade disso, por isso competem entre si. A competição é acirrada ainda à medida em que as máquinas contraditoriamente impulsionam o processo de desemprego estrutural, a crise da terceira revolução industrial (KURZ).

Nesse contexto, Fagundes deixa bastante claro que a $12^{\mathrm{a}}$ classe é o limite entre quem compete por trabalho e quem é supérfluo na relação, esses que se tornaram obsoletos do trabalho abstrato, ou seja, pouco rentáveis e já não servem para a acumulação.

Então, ainda que Márcio e Fagundes sejam moçambicanos, eles encontram-se em situações distintas. Márcio está empregado, ainda que possa ser em condições precárias ele tem salário. Já Fagundes é tido pelo processo como supérfluo e ao não ter trabalho potencializa esse momento de escassez em que vive, escassez que é escancarada após o processo de reassentamento que retirou o que era base para a reprodução de sua família: a machamba.

Entre o que tem trabalho e o supérfluo, há ainda aqueles que se mantém na competição por trabalho. Por exemplo Enia. Ela vive atualmente com a mãe, o marido e um filho numa casa que é mantida pelo companheiro de sua mãe, um zimbabuano, migrante sazonal, que divide sua vida entre Moçambique e Zimbábue. Enia já esteve em situação de prostituição. Recentemente fez um curso de formação com a Vale S/A e diz que vai ser contratada, mas ainda não sabe qual trabalho exatamente vai realizar, quando vai começar, nem quanto vai ganhar, disse que deve ser entre 12 mil e 40 mil meticais ${ }^{104}$. Ela não considera nenhum dos dois valores baixos e acentua que ao salário são somados

${ }^{104}$ Entre 200 e 600 dólares. 
outros benefícios e lamenta que serão 12 horas de trabalho diariamente, das $8 \mathrm{~h}$ às $20 \mathrm{~h}, \mathrm{e}$ dependendo da função pode ter de trabalhar a noite, fazendo turnos. É uma ideia vaga de uma possibilidade futura, com informações imprecisas, mas grandes expectativas e o que a coloca na relação e permite competir pela vaga de trabalho é o fato de ela ter cursado a $12^{\mathrm{a}}$ classe.

Nesse contexto, alguns interlocutores dos reassentamentos positivaram que a Companhia Carbonífera pagava escola, pois essa é a barreira que aparece atualmente e por isso é uma das reivindicações para com a Vale S/A de que possibilite que os jovens estudem para poderem competir pelos postos de trabalho, a reivindicação da dignidade humana secundária (HEIDEMANN, 2004).

É como se naquele período a Companhia realizasse o que reivindicam que a Vale S/A realize no momento presente: vagas de trabalho para os moradores dos reassentamentos para que eles possam ter salário, vagas em escolas, que sejam incluídos e por isso a contradição positiva o período colonial. Entre outras situações colocadas como de benevolência por parte da Companhia, ao compararem à Vale S/A, interlocutores lembraram das festas de fim de ano que participavam na Companhia. Sem olharmos para a totalidade do processo, esses momentos podem parecer como elementos que qualificam positivamente a Companhia Carbonífera, como um ato de generosidade sobretudo ao ser analisado de forma comparativa ao contexto atual. Mas Coelho (2013) em seu romance ilustra a "festa da firma":

Um funcionário negro vestido de vermelho, com barbas de algodão e bochechas enfarinhadas para parecer um Pai Natal de verdade, crianças brancas refugiadas no colo das mamãs, assustadas com a incongruência do monstro. Quanto às outras crianças, que também havia - os futuros funcionários filhos dos actuais funcionários, dizia o diretor-geral, como se lhes concedesse uma benesse - permaneciam ao fundo do salão caladas e quietas, cientes já da hierarquia, capazes já de uma timidez de adulto subalterno embora ainda não de reparar em quão suspeita era a generosidade dos patrões dos seus pais. E por fim as prendas, distribuídas em rigorosa consonância com a dita hierarquia, deslumbrantes bonecas francesas para as filhas dos engenheiros belgas, minúsculos carrinhos de lata para os filhos dos estafetas e dos cozinheiros (COELHO, 2013: 177).

Para nós, esse trecho expõe as relações de dissociação valor naquele período.

O processo inverte a relação. A princípio os estudos eram obrigatórios por parte do regime colonial, hoje os estudos passaram a ser uma reivindicação, mas com a mesma finalidade: ter condição de competir pelo trabalho. Com a situação atual que se apresenta 
e vive como de escassez e de necessidade de dinheiro, as contradições do que foi a imposição do trabalho tomam outros níveis.

O que é apresentado hoje é que a Vale S/A não oferece a possibilidade daquilo que é compreendido por eles e pelos movimentos sociais como de direito: estudar, enquanto a Companhia Carbonífera pagava para que os estudos fossem realizados. E nesse sentido, eram incluídos no processo e na sociedade produtora de mercadorias, pois de fato era essa a finalidade dos estudos, enquanto que atualmente estão excluídos do processo e a responsabilidade é jogada para os próprios sujeitos.

Nesse aspecto, o interlocutor Fagundes expôs como a dissociação entre o migrante (trabalhador especializado) e ele (supérfluo) é um processo estrutural a partir do que ele relatou sobre sua particularidade:

Tenho 42 anos. Cresci num tempo difícil. Casei. Eu não estudei, mas meus filhos podem estudar. Mas estão na mesma e vão ser como a mim sempre. A escola secundária aqui paga-se. Com 3, 4 filhos é muito, precisa dinheiro. Eles vão dizer: "Ah vocês não querem meter os filhos na escola, querem ser brutos”. Mas eu não tenho possibilidade! Por causa: caderno é comprar, lapiseira é comprar. Tudo é comprar! Esse dinheiro onde vou encontrar? É ficar camponês. Em casa não é bom ser todos cegos. Quando todos vocês são cegos, quem vai ver? (FAGUNDES, 2017)

O processo é estrutural e é iluminista.

Pela particularidade do empírico que Fagundes relata, a ideia de que a empresa multinacional gera empregos em Moçambique e com isso promove o desenvolvimento humano é desconexa. A ideia abstrata à qual os sujeitos burgueses impõem de que a felicidade se realiza pelo trabalho não se realiza para ele e para muitas das pessoas que vivem nas mesmas condições, pois contraditoriamente o processo reverte o sentimento para frustração por ter, inclusive, piorado o que eles viviam antes, aumentando a escassez. Práticas que envolvem as necessidades físicas e também os seus desejos, ou seja, tanto no plano concreto quanto no plano abstrato das relações sociais são frustradas, ao mesmo tempo em que joga para os próprios indivíduos a responsabilidade para que a tal felicidade e a reprodução das necessidades se realize, conforme Kurz formula:

A pressão para que os indivíduos busquem sua felicidade em meio às pressões do movimento de valorização é, nessa medida, idêntica a uma monstruosa ameaça, porque em primeiro lugar, predetermina a história da felicidade como a história do sofrimento e do abuso, e, em segundo lugar, porque, mesmo no interior do sofrimento e do abuso, admite o completo fracasso e a perda da existência social (KURZ, 2010: 45). 
Os abusos e o sofrimento são representados pela $12^{\mathrm{a}}$ classe que é o que aparece como justificativa da não contratação culpabilizando o próprio indivíduo pelo fracasso do sistema. Mosca \& Selemane (2011: 29), pesquisadores moçambicanos, tiram essa pressão dos indivíduos e atribuem a baixa qualificação e experiência profissional dos moradores de Tete e Moatize como um resultado da rápida procura por trabalhadores qualificados, sem que houvesse tempo suficiente para que o Estado pudesse ter dado orientação política educativa na formação técnica e profissional, ou seja, os pesquisadores apresentam o problema como uma questão de planejamento estatal e resultado da aceleração do processo de produção que não permite o tempo necessário para formação da força de trabalho. O que acrescentamos ao argumento é que na totalidade essa força de trabalho já existe e nesse sentido, para o fim em si do processo, já existem as condições de produção.

O desenvolvimento das forças produtivas acelera a circulação das mercadorias e entre elas a força de trabalho. Com isso a circulação de trabalhadores no distrito é alta e os contratos firmados para trabalho são de curto período. Foram inúmeros os relatos que os interlocutores fizeram sobre migrantes que faziam a mediação entre a empresa e a comunidade e que agora já não estão mais em Moatize. São muitas as funções executadas, diferente duração de cada atividade e diferentes origens dos migrantes, conforme já apresentamos. E eles tem uma relação de sociabilidade no lugar, mesmo que temporária.

Nesse sentido, a partir desses trabalhadores considerados aptos para trabalharem e que então supostamente atingiram o objetivo da felicidade que foi vendida pelos ideais burgueses, desdobram-se outras questões na comunidade de Tete, de Moatize. Uma interlocutora apresentou:

Há os que chegam para trabalhar e conquista uma miúda. Ela faz tudo para o marido. Há meninas que abandonam a escola: arranjaram bom homem, tem bom salário. Engravida. Ai acaba o contrato do homem, ele vai embora, sai sem se despedir, desliga o telefone, nem atende! Deixa a criança sem nenhuma condição. Ela deixou a escola cedo, os familiares sem condições para apoiar. Muitas das meninas estão a ser afetadas. Outros aparecem, não são honestos... Apanham uma miúda e não consegue falar que está nestas condições. Alguns são soropositivos, escondem. As meninas não tem coragem de dizer "vamos ao teste" porque parece que está a desprezar. Aceita logo sem saber que o homem já está infectado. Ele fica pouco tempo, deixa criança e já te contaminou! São moçambicanos, sul-africanos, zimbabuanos. Muitas das mulheres abandonaram o marido também. Muitas envolveram-se com brasileiros. Dizem que apanharam homem empregado, aceita o homem, fica 
com ele por meses. Mas ele basta acabar o contrato e vai. Deixa a mulher na desgraça (MIRIAM, 2017).

Essas situações foram apresentadas como relações que tem contribuído com o aumento da violência contra as mulheres, tanto quanto a obrigação das atividades domésticas e das machambas que já apresentamos no capítulo 2. As relações mesmo que efêmeras interferem nas práticas sociais em meio a suas famílias e sua comunidade, aumentando assim a vulnerabilidade social dessas mulheres.

O asselvajamento da ordem patriarcal (Scholz) faz com que a situação se apresente como de desejo e esperança para as mulheres a relação com um homem bem empregado, enquanto para os homens, conforme acima mencionado, uma relação que envolve o que não está dito, pois ele está no controle da situação e é quem está de passagem por ser migrante. Vale dizer ainda que a mulher negra moçambicana foi caracterizada por algumas das interlocutoras como uma mulher idealizada por brasileiros, ao elas terem uma postura de quem agrada aos maridos e realizam os trabalhos domésticos, expondo assim a dissociação e a relação de dominação sobre uma mulher que não trabalha e não tem salário, ou seja, depende financeiramente do salário do homem.

Esse processo nos remete à análise da migração temporária no Brasil que Martins (1986) fez. Ele diz que a migração temporária é uma transição em que a vida divide-se em espaços geográficos diferentes. Uma pessoa é como duas pessoas ao mesmo tempo por ter em cada lugar uma relação específica. $\mathrm{O}$ autor formula que:

Sociologicamente falando, o migrante temporário, ao retornar já não é o mesmo; e, por ter que sair, nas condições em que sai, modifica as relações sociais do seu grupo de origem, altera a organização da família, a divisão do trabalho familiar, o lugar de cada um. O que encontra, quando retorna, já não é o que deixou (MARTINS, 1986: 45 - grifo nosso).

Acreditamos que esse processo pode ser bastante semelhante ao processo que já expusemos anteriormente, como o caso dos moçambicanos migrantes que iam trabalhar na África do Sul ou na Rodésia do Sul, ou ainda trabalhadores que iam de forma sazonal para os trabalhos forçados e assim eram retirados da unidade de produção. Mas a partir dos registros e relatos das mulheres que vivem em Moatize, podemos olhar para o lado das mulheres que se relacionam com migrantes. Esse é o lado onde o trabalhador migrante está de passagem. Ao olharmos para as mulheres que estão nesse outro lado dessa vida dupla masculina, o lado temporário e que pode nem mesmo ser relatado por esses homens por não ser, digamos, a história oficial, compreendemos em maior profundidade que o que eles deixam quando vão embora também já não é como encontrou. Sendo assim, além 
da perda das machambas - conforme expusemos no capítulo 2 - incidem sobre essas mulheres questões morais em torno do que vem a ser as relações matrimoniais e as relações familiares, que são as relações que as colocavam em coletividade tanto no aspecto da produção nas machambas quando tinham acesso à terra, quanto pelo aspecto do compartilhamento de práticas familiares. O processo faz com que elas sejam entendidas individualmente, como sujeitos, mas sem trabalho e retomamos a reivindicação do que entendemos como dignidade humana secundária (HEIDEMANN, 2004) com o que Osório \& Silva (2017) apresentaram como empoderamento das mulheres e raparigas.

\section{2. “As pessoas não estão a trabalhar, estão a viver à maneira”. Supérfluos}

Há uma importante diferença geracional na forma em que os moradores dos reassentamentos se relacionam enquanto sujeitos no processo de modernização. Os homens mais velhos em parte são ex-mineiros, enquanto os homens mais novos dizem ter tido suas expectativas por virem a trabalhar na empresa de mineração frustradas. As mulheres mais velhas estiveram boa parte de suas vidas nas machambas, enquanto as mulheres mais novas desdobram-se para tentarem continuar suas práticas nas machambas e declaram que já não tem possibilidade de manter a atividade, o que também se apresenta como uma grande frustração e que se desdobra em muitas preocupações do porvir.

Ao olharmos para a história em Moçambique, voltamo-nos ao período pós Libertação em que a dignidade humana secundária (HEIDEMANN, 2004; KURZ, 2016) é lembrada por meus interlocutores: Esse tempo era bom! O jovem entrava na CARBOMOC até ser madala, até reformar. Esse madala levava o filho pra ir trabalhar. E ele trabalhava. Trata-se de uma memória que exclui os conflitos daquele momento, mas acreditamos que seja por contrapor a escassez em que vivem atualmente. Compreendemos que no ponto em que meu interlocutor narra, os trabalhadores podem ser entendidos como sujeitos de direito num contexto em que a primeira geração que apresentamos acima viveram, de modo que alguns dos homens mais velhos dos reassentamentos são atualmente aposentados, que em Moçambique dizem ser trabalhadores reformados. Isso lhes garante um salário mensal de aproximadamente $3400^{105}$ meticais, compreendido por eles como resultado do trabalho assalariado que exerceram. E isso os diferencia dos jovens que, por mais que se coloquem disponíveis ao trabalho, não encontram quem compre sua

\footnotetext{
105 Aproximadamente US\$ 60,00 conforme câmbio na data da pesquisa em campo.
} 
força de trabalho, pois se tornou pouco rentável e, dessa maneira, os mais velhos do reassentamento questionam sobre o futuro desses jovens que não irão se aposentar por atualmente não trabalharem, ou seja, não terão essa mínima possibilidade de entrada de dinheiro e as incertezas estão postas.

Durante a pesquisa de campo foi frequente essa exposição de que não há trabalho e, até determinado momento, dificultou a intenção que era perceber as práticas rentáveis que eram realizadas e de compreender como aquelas pessoas se reproduziam. Essa lacuna foi preenchida mais pela observação que as idas aos reassentamentos permitiram e, assim, pude perceber quais os trabalhos informais que eram realizados. Ao retornar da pesquisa de campo e retomar a trajetória e entrevistas foi então possível perceber que a pergunta estava sendo feita errada. O Sr. Julio, membro de uma das associações e morador de Cateme, explicou que: as pessoas não estão a trabalhar, estão a viver à maneira. Não tem nenhuma atividade, mesmo para sobrevivência é difícil.

Conforme já apresentamos anteriormente - principalmente no item 2.3, quando falamos sobre as atividades realizadas pelas mulheres -, o trabalho não é uma relação entendida de forma naturalizada, como mero metabolismo com a natureza. Ao apresentarmos a Lei do Indigenato, levantamos a questão do que era considerado trabalho, pois era o que produziria valor para o Estado colonial. Supomos assim que trabalho é entendido por meus interlocutores como aquilo que tem a mediação de uma empresa, em que a produção é para o outro e realizam uma parte da produção. Portanto, não há trabalho e os trabalhos informais e as atividades agrícolas não são considerados como tal e por isso são chamados de tarefas, maneiras...

Outro interlocutor, o Sr. Julio, seguiu em sua exposição sobre as formas de reprodução no reassentamento:

No tempo de salário muita gente aqui do reassentamento ia pra Angónia, comprava milho, feijão, verduras, alguns tinham bancas, compravam arroz. Já não necessitava das pessoas que chegavam da vila. Logo que recebiam salários, faziam suas compras. Ai era o desenvolvimento praquela gente que não tem emprego. Trazia mercadoria e vendia para aquele empregado. (SR. JULIO, 2017).

O tempo do salário a que ele se refere foi quando alguns dos homens que hoje vivem nos reassentamentos foram contratados pelas construtoras Odebrecht e Ceta para trabalharem na etapa de implantação das minas e com isso recebiam salário. Atualmente é bastante comum ver moradores nos reassentamentos transitando com antigos uniformes e equipamentos da empresa. 
O Sr. Julio explicou a dinâmica a partir da circulação do dinheiro no reassentamento que era obtido por alguns moradores na forma de salário a partir desse trabalho. Esse dinheiro permitia o comércio daqueles que não estavam empregados e não necessitava das pessoas que chegavam da vila. Nesse sentido, o isolamento gerado pela distância dos reassentamentos em relação à vila de Moatize não parecia ser problema, pois havia dinheiro que circulava entre eles que chegava pelos próprios moradores que tinham trabalho assalariado.

As mamás tinham dinheiro para pagar transporte, iam buscar alimentos e revendiam no próprio reassentamento. Com a venda dessas mercadorias, tinham dinheiro para comprar outros produtos para continuar a revenda. Os homens que fabricavam móveis vendiam para os próprios moradores do reassentamento, ainda que em algum momento os compradores pudessem chegar ao seu limite de necessidade da mercadoria. Essa última atividade era realizada principalmente ao reassentamento Cateme, pois de lá é possível acessar matéria prima. No reassentamento 25 de setembro, essa atividade tornou-se praticamente impossível, visto que as áreas ao redor estão cercadas impedindo o acesso à matéria prima.

Assim, o tempo do salário ficou na memória dos meus interlocutores: Eles quando começaram com a empresa, quase recrutou todo jovem de Moatize. Os jovens tavam a trabalhar.

Eles vinham e faziam reunião com a população: "Vocês jovens vão trabalhar, não vão ficar desempregados". Então pensamos: os brancos vieram, nós vamos trabalhar mesmo. A Vale? Nos levaram bem. Foram no bairro [Chipanga]. Falavam com líder e então o chefe de quarteirão inscrevia as pessoas e ia trabalhar, mas quando nos tiraram de lá para aqui, acabou. (FAGUNDES, 2017)

Essa etapa da operação realizada pela Odebrecht teria durado em torno de 2 anos e com o fim dos trabalhos dessa etapa, aqueles que foram contratados e recebiam salário foram dispensados e não mais contratados para nenhum trabalho envolvendo a mineradora, conforme apresentamos no item anterior. O ser supérfluo ao sistema, marcado por não ter a $12^{\mathrm{a}}$ classe, reivindica por trabalho, pois: Agora ficamos aqui de braços cruzados, sem fazer nada. Esse é um ponto que aparece como de desilusão para quem acreditava que o período do trabalho, ou melhor, o período de salário seria igual ao período de exploração do carvão mineral.

A desilusão desses trabalhadores segue ainda por constatarem que eram incluídos quando o trabalho na mineração era explicitamente mais penoso e perigoso pelas 
explosões nas galerias, inclusive podendo ter sido motivo do estopim para um massacre marcado na história do distrito e da Companhia Carbonífera. Enquanto que, na atual conjuntura, quando as relações de trabalho são mais modernas e consideradas mais seguras, eles não são considerados. Nesse aspecto, entre os ex-mineiros e moradores dos reassentamentos predomina a incompreensão da exclusão, pois acreditam que são eles que conhecem bem o lugar e o carvão. No entanto, não conhecem as técnicas do trabalho, o atual processo que transforma o carvão do lugar em mercadoria.

O tempo do salário foi seguido por uma indenização que os reassentados receberam após muito reivindicarem. Essa indenização foi inicialmente fixada em 87.500,00 Mt e, mais tarde, reajustadas para 112,000,00 ${ }^{106}$ Mt (SELEMANE, 2010) e visou compensar um hectare de terra que seria para machamba para cada uma das famílias mas que não há nos reassentamentos (OSÓRIO \& SILVA, 2017: 56). Essa entrada de dinheiro deu possibilidade de consumo por um período, sobretudo aos homens, visto que na ordem patriarcal das relações capitalistas, a indenização foi paga àquele que é entendido como chefe da família. Quer dizer, o dinheiro foi dado ao homem e ele tomou as decisões do uso do dinheiro, sem consultar as mulheres e muitas das vezes sem incluílas no consumo desse dinheiro. Pelo contrário, algumas mulheres relataram que com o dinheiro da indenização, muitos homens pagaram lobolo de outra esposa e afinal elas ficaram sem o marido, sem machamba, sem indenização. Um membro de uma das associações explicou como ocorreu aquele momento:

As pessoas foram indenizadas pelas machambas. Agora o dinheiro, tu indeniza uma pessoa que nunca teve projeto, nunca pegou aquele tipo de dinheiro. Dinheiro né, para ele pode ser muito. Agora ele vai fazer o que com esse dinheiro? Não tinha projeto, dar ao camponês, sem um projeto sustentável da vida dele. Isso foi a pior coisa que foi feita. As pessoas usaram o dinheiro para fazer isso, não sei o que que que. Compraram motorizadas, televisão, coisas que eles não tinham e querem ter também né. As pessoas querem ter boa vida, quem não quer? Mas epah! Acabaram ficando mais pobre. Não foram capacitados a ter um projeto que aquele dinheiro que estão a receber possa sustentar a eles a curto, médio e longo prazo. (IVAN, 2017)

No que ele aborda, o dinheiro da indenização foi usado para realizar o desejo do consumo material. Mesmo assim, muitas das casas visitadas ao longo da pesquisa de campo mantinham seus cômodos um tanto vazios, sem móveis e principalmente sem eletrodomésticos, evidenciando o baixo consumo dessas mercadorias. Para muitos dos

${ }^{106}$ Equivalente a aproximadamente US\$ 3.000,00 naquele período. 
reassentados esse aspecto não aparecia como problema, pois quando descreviam suas necessidades materiais, o problema que era exposto estava relacionado às rachaduras das casas, o medo delas ruírem.

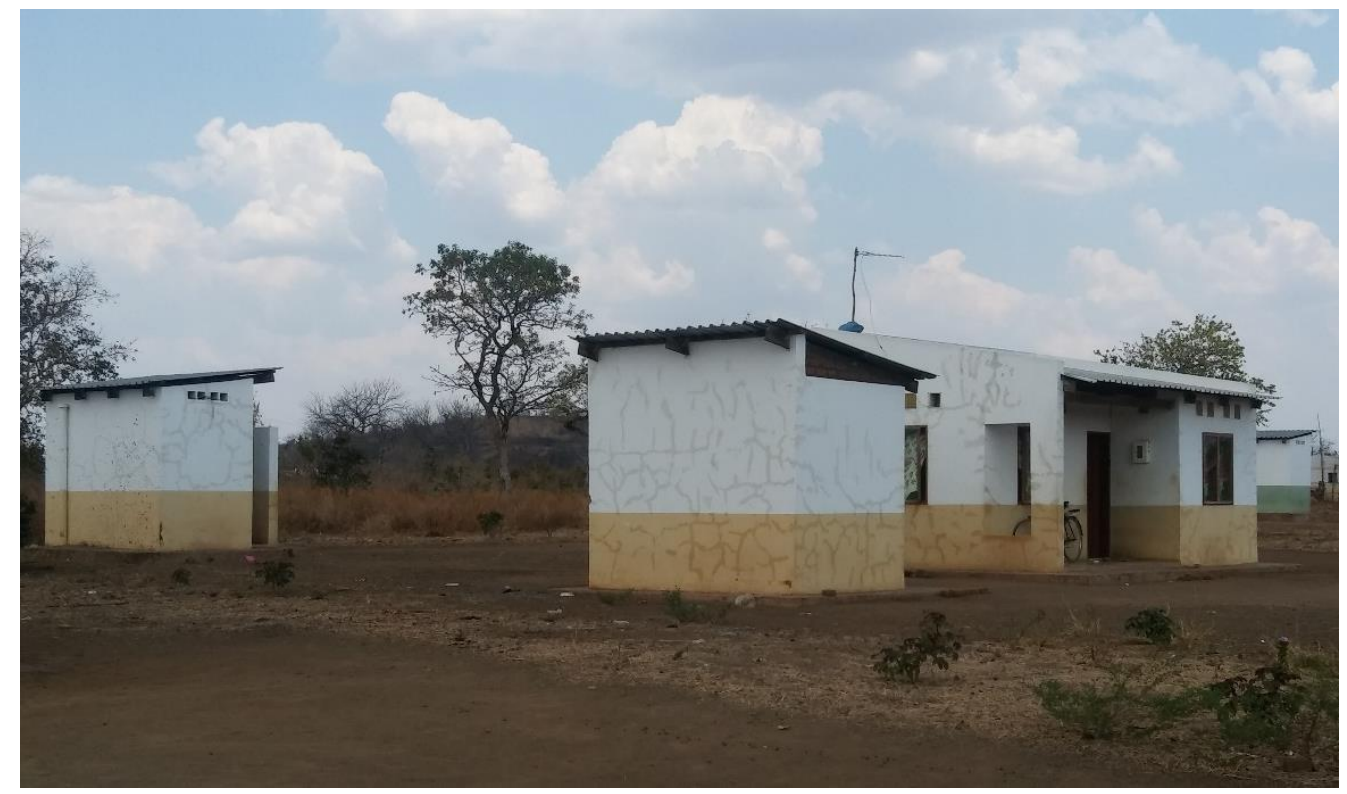

Figura 11: Casas com muitas rachaduras no reassentamento Cateme. Fonte: Viviane Alves Vieira - 2017

Voltamos para o processo que Ivan apresentou: o dinheiro recebido pelas indenizações acabou e ele reclama que não houve programas que orientassem as pessoas no uso do dinheiro ou como poderiam investir em algum negócio. Conforme expusemos, a relação com o dinheiro entre as pessoas que foram reassentadas sempre esteve pela forma de salário ou ainda como equivalente na troca de mercadorias. Não esteve como capital, ou seja, não reproduzia, não acumulava. Deste modo, o uso do dinheiro esteve como sempre foi, mas essas pessoas não tiveram novos pagamentos e, após esse dinheiro ser colocado em circulação, não retornou e acabou.

Então como se vive à maneira atualmente?

Qualquer forma de obter dinheiro pode ser considerada. Os homens vendem a força de trabalho nos trabalhos esporádicos, como um senhor do reassentamento 25 de setembro que ajudava uma pessoa na cidade a carregar materiais de construção civil num galpão. Há mulheres que tentam manter a atividade de venda dos produtos da machamba e estendem em frente a suas casas ou mesmo no mercado construído pela Vale S/A em Cateme pequenos montinhos de murchos dentes de alho soltos, punhados de grãos de 
feijão, sementes de malambe ${ }^{107}$, espetinhos de ratos fritos, bananas bem pequenas e ainda verdes. Para quem comprar?

Em Cateme ainda é possível a coleta de madeira das árvores chamadas de chanfuta, madeira utilizada para a fabricação de móveis, é também possível a coleta de lenha para uso e venda como carvão vegetal. No entanto, para a venda desses produtos, eles devem ser levados para a cidade, pois não há consumidor no local e são escassas as maneiras de levar. Alguns moradores insistem na atividade pela necessidade do dinheiro e se organizaram de modo que motoristas do transporte coletivo, os chapas, carreguem sacos de carvão vegetal sobre os automóveis, quando vão levar passageiros até a vila. Para os moradores que entregam a lenha para esse mediador fica uma quantidade de dinheiro um pouco inferior do preço que a lenha é vendida na vila de Moatize. Essa é uma atividade pouco rentável e de grande concorrência na vila.

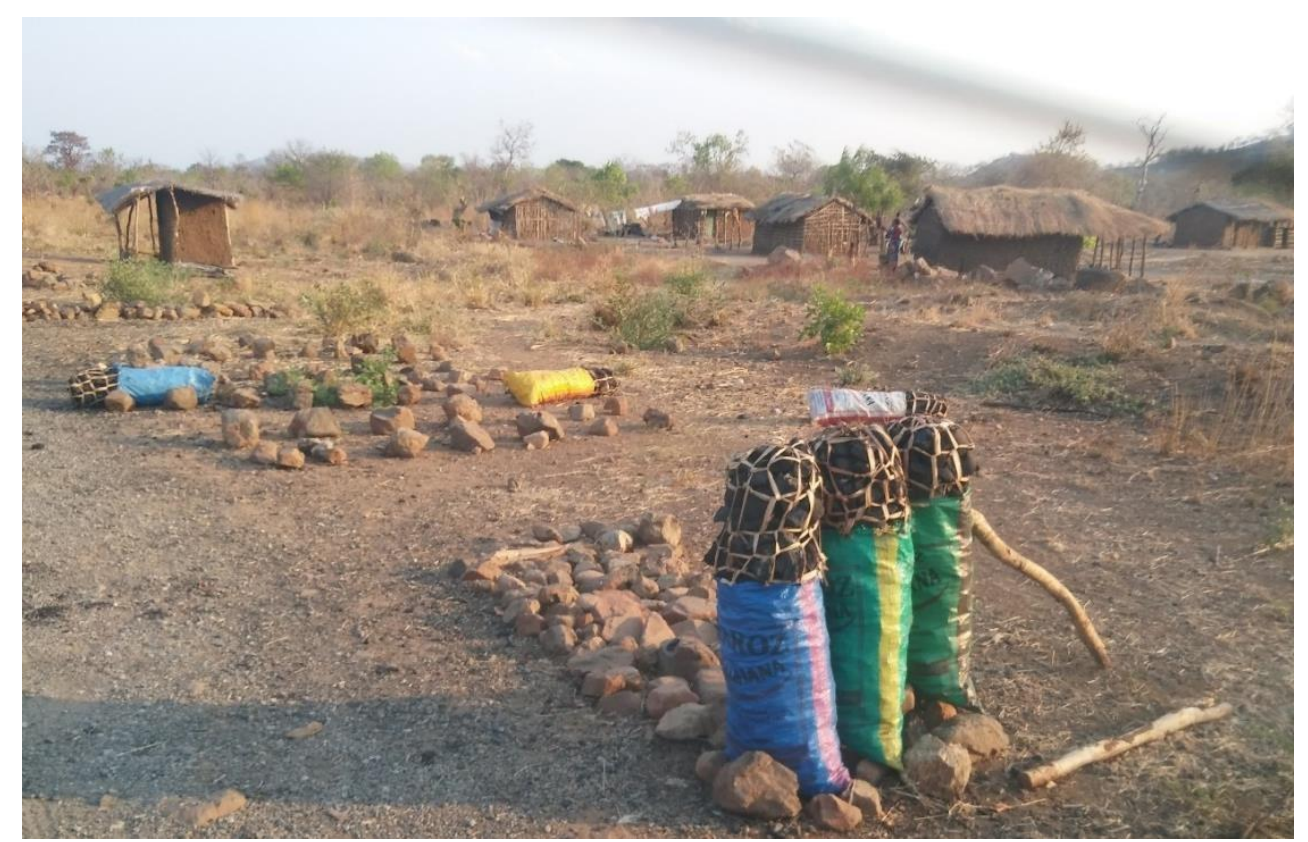

Figura 12: Venda de carvão vegetal no caminho entre o reassentamento Cateme e a vila de Moatize. Fonte: Viviane Alves Vieira - 2017

Ao irem se esgotando as possibilidades de obter dinheiro, as pessoas que vivem nos reassentamentos vão vendendo o que podem: as chapas de zinco que antes cobriam as casas, as portas e as janelas. Aos poucos as casas que já aparentavam não ter sido construídas para durar, vão aumentando o estado de degradação, aumentando a aparência de improvisação do que constitui os reassentamentos e o desconforto no dia-a-dia das pessoas.

\footnotetext{
${ }^{107}$ Semente do embondeiro, também conhecido como Baobá. A semente é usada principalmente para fazer iogurte.
} 


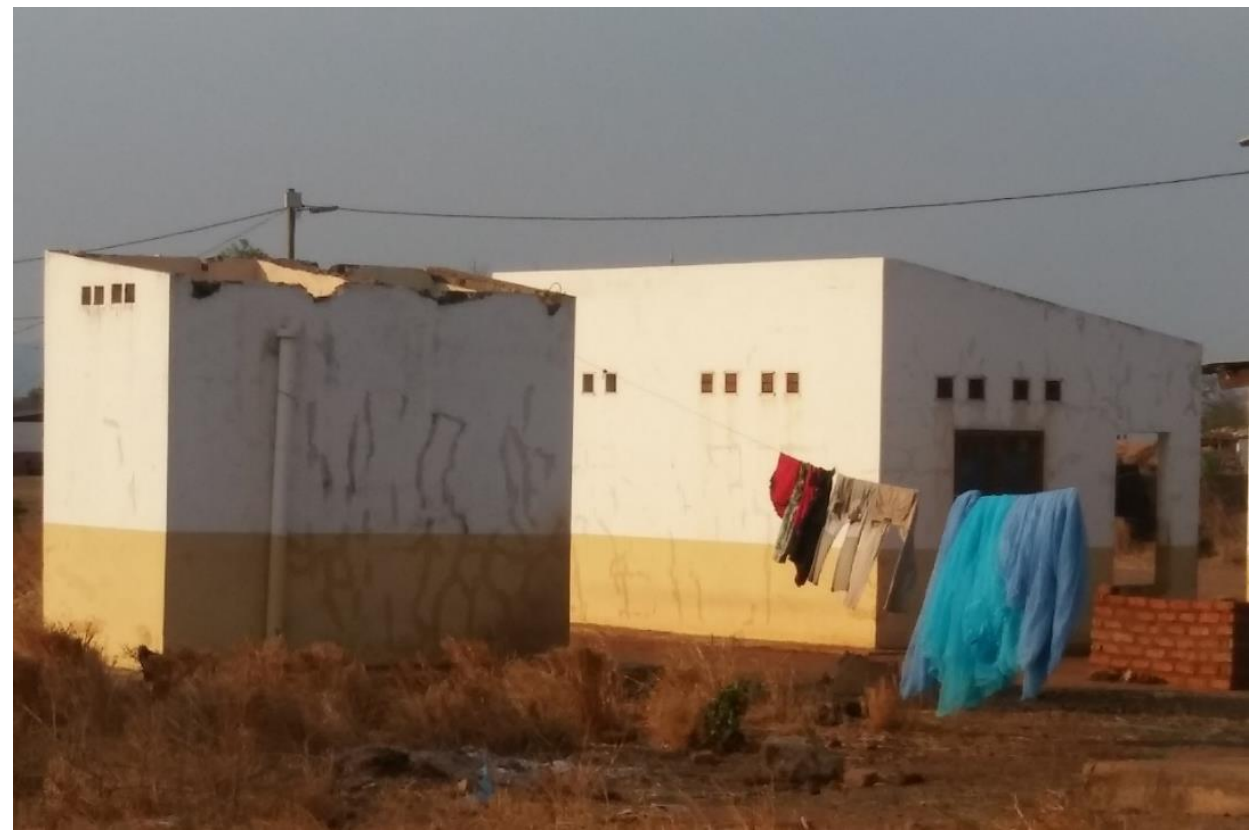

Figura 13: Casas sem telhados. Fonte: Viviane Alves Vieira - 2017

Sobre esse aspecto um morador de Cateme explicou:

Muita gente vendeu chapa da cozinha, da casa de banho, por causa de sofrimento. Não tem meio de fazer. Até outras pessoas estão a vender a casa, para ter maneira de comer. Ir pro mato! Fugir porque é uma vergonha. Fugir no mato e não dá para ficar no mato. É sentimental... Aí vem alguém perguntar: “tão a vender casa porquê?” Se não esses filhos vão morrer! Então vendem a casa para viver. É melhor ter uma casota no mato e comer (FAGUNDES, 2017).

Vendem o que pode ser útil para o outro para terem meios de comer. Ainda assim tem se alimentado mal e passam fome. Num limite das possibilidades e do esfacelamento das relações, essas pessoas, vítimas de um megaprojeto de desenvolvimento, refugiam-se dessa catástrofe para áreas mais distantes, no mato, como dizem, sendo desagregadas e desenraizadas socialmente mais uma vez e atiradas para fora do sistema global capitalista.

Fagundes vive em Cateme. Alguns moradores de Cateme relataram que há quem vendeu a casa ou parte do terreno que seria destinada às machambas e de onde poderiam ter alimento, caso eles tivessem meios para produzir naquela terra infértil. Esses moradores vendem parte do terreno para pessoas de outros povoados que por algum motivo vão viver na área do reassentamento. Ao serem questionados, os interlocutores não souberam dizer o fator de repulsão do local de origem dessas pessoas que vão viver no reassentamento, mas afirmam que há interesse em ir viver onde há energia elétrica, onde há uma aglomeração se formando. 
A transação da transferência da terra é feita com a legitimação de testemunhas. Sr. Julio explicou:

A cada um de nós reassentado foi atribuído uma área de 100x45m. Então aquela pessoa se chegar a mim e contactar: preciso de um talhão para fazer a minha casa, então eu combino com ele. Ele dá me dinheiro. Então eu vou lhe dar uma porção.

[Mas e se quiser a terra de volta?]

Não, não. Já não vou precisar. Já não vou querer. Tem um documento, com testemunha do comando das lideranças. Servem de testemunho. (SR. JULIO, 2017)

Ou seja, aqui não há DUAT, nem a relação de herança da terra pelo sistema costumeiro.

Já no reassentamento 25 de setembro, foi relatado que pessoas que tem famílias em outras zonas deixaram as casas para alugar: Abandonaram casa sim. Meteu cliente ali, alugaram. É preferível ficar lá lá lá fora na machamba. Alugam e levantam dinheiro para levar criança a escola, mas aquele que não tem família lá fora como vai conseguir machamba? (AMÉLIA, 2017). Apontamos primeiramente que a relação de aluguel é possível, visto que esse reassentamento está na vila e próximo de pessoas que recebem salário e entre as pessoas que alugam as casas dos reassentamentos estão os próprios trabalhadores da Vale S/A, aqueles trabalhadores moçambicanos migrantes. Um interlocutor disse que são pessoas do sul, que saíram de Maputo, Beira ou Gaza para trabalhar na Vale S/A. No condomínio da Vale S/A, os trabalhadores pagarim 8.000 meticais mensais, então ao alugar uma casa no reassentamento, que está ao lado do condomínio, pagam 2.500 meticiais mensais ${ }^{108}$. Em segundo lugar, a saída das casas é possível por serem pessoas que tem família em outro lugar, pois conforme relataram e já apresentamos, as poucas áreas férteis naquela província quente e seca, muitas das vezes já tem família que cultivam machamba.

Por fim, quando não se tem mais meios de vender a força de trabalho, nem objetos para serem vendidos, nem casa, nem terreno, o que fazer? Os corpos são postos em risco, das mais variadas formas de violência: nós jovens vamos sofrer. Não temos $12^{a}$ [classe] e precisa de nível para trabalhar. Mas sou jovem! Como vou fazer? É roubar. Esse mesmo interlocutor coloca luz ao processo e transcrevemos sua fala, por apresentar de forma particular o que à distância não se percebe:

${ }^{108}$ Equivalente a aproximadamente $\mathrm{R} \$ 470,00$ e R \$145,00 respectivamente com câmbio de 2017. 
A vale está a sofrer com o roubo de verdade, mas deveriam analisar de onde sai o roubo. O roubo sai da pobreza! Você quando tem não vai roubar. A Vale deveria contratar da zona. Um exemplo né: Você vieste aqui e você pode conhecer coisa daqui? Não! Pra conhecer tem que ter conosco. Quando ter conosco, nós vamos dizer: aquela casa não está boa, cuidado aí. A vale não faz isso! Vai na zona e dá uma camisola, enquanto a pessoa não quer camisola. Quer dinheiro para sustentar os filhos! Aí fizeram o que? Uma vedação! Eu nasci aí, eu sei mesmo. A vale está vedando com aquela população que está aí. Tem muitos jovens que não estão a trabalhar e todos os dias entra na vale: "o que posso levar?" Então hoje choram: “estamos a ser roubados, os moçambicanos são ladrão". São ladrão sim! Porque estão desempregados, estão a sofrer. Eu não posso ver uma pessoa a comer e eu ir dormir com fome. Vou roubar! Vou roubar mesmo! Eu, para comer, vou fazer o que? Vou levar aquela farinha e vou comer com meus filhos. Porque eu já fui roubado! Vocês estão a comer sozinho e eu não! Então faz aqui também um pouco e então não há de haver o roubo. Eu estou a ver, está na minha vista! Aí colocam segurança. Segurança é o que? Segurança é de onde? Segurança dorme. Dorme mesmo! A Vale é grande mesmo, é conhecido mesmo. É pra poucas pessoas, não são negros não. Há uma barreira no meio. É sentimental mesmo.

A barreira é física e é uma dissociação pelo próprio processo de modernização que segrega e exclui da relação ao mesmo tempo em que interfere nas práticas cotidianas dessas pessoas, intensificando o processo de expropriação o que o faz sentir-se roubado primeiramente.

Nesses meandros, ao relatar sobre as mulheres que ainda vivem em Mithethe, atrás da área de concessão da Vale S/A, ou seja, daquele grupo que faz parte das famílias que não foram removidas e hoje vivem próximas à área de mineração, um interlocutor relatou:

De lá pra vila é uma distância para ir à moagem e com uma lata de milho para moer. ${ }^{109}$ Tinha uma estrada, mas já não há. Ali está cheio de bandidos lá: arrancam as motorizadas, motocicletas. Esse tempo de fome também quando vê uma senhora sozinha com milho na cabeça, arrancam. Torna difícil para ir moer. Estão lá a sofrer. (Lionel, 2017).

O momento presente, de humilhação de segundo grau em massa em que os supérfluos ao sistema perdem as machambas, foi chamado por Lionel de tempo de fome, assim como muitos em Moçambique se referem ao período da guerra e também como a historiografia revelou o período do auge da colonização e de maior exploração de mais

\footnotetext{
${ }^{109}$ Um dos principais alimentos em Moçambique é a xima, um prato feito com farinha de milho branco. As idas às moagens é uma atividade realizada geralmente pelas mulheres.
} 
valia da força de trabalho moçambicana com os trabalhos explicitamente forçados, todos períodos de fome.

O Sr. Lionel, que é um dos moradores mais velhos de Cateme, tem essa memória: fome é fome mesmo. Quando vc está a sentir fome, não há pessoas, não há nada. Tem pessoas que chega a pedir. Tem que arranjar uma forma. Ele lembrou maneiras que naquele período pessoas lidavam com a situação. O pai dele contou que quando esteve no Zimbabwe e via que não tinha onde dormir, pegava uma criança e dava porradas sem motivos, até a polícia aparecer. Então a polícia o levava para dormir na prisão. No dia seguinte revelava a intenção. E o que ficavam eram as reclamações da polícia: " $A h$, você é malandro, vai embora". E então o Sr Lionel resume: são maneiras. Ao retornar para o presente ele coloca essa própria maneira como não mais possível e conta que pode acontecer que quando apanham um ladrão ali, as pessoas pegam, amarram, pega gasolina joga e depois: fogo. Morreu assim. Assim mesmo. Toda a gente vê. Ah... Fome é problema. Essa é uma face do processo de modernização, a sua negatividade, a barbárie.

E como quem pede um respiro no meio dessa barbárie, novos pedidos de indenização são formulados. Em 2017, membros das associações estavam cadastrando os antigos oleiros para oficializarem o pedido de indenização pela perda da atividade. $O$ distanciamento da várzea do rio prejudicou a fabricação de tijolos pela necessidade de sedimento. $\mathrm{O}$ distanciamento da vila rompeu com a rede de comércio em que pessoas iam até o bairro comprar os tijolos e não há maneira de irem de transporte para vender para os boss $^{110}$ na vila. $\mathrm{O}$ resultado foi que parte dos homens perderam uma importante atividade. Mas o que foi noticiado é que em 2018 houve novo acordo com indenização para compensar as casas que estão degradas. No entanto, a questão permanece: e quando o dinheiro da indenização acabar novamente?

O que aparece é esse vizinho gigante, que impede a passagem, que tirou as machambas e que torna o dia-a-dia ainda mais insuportável com o rastro de poluição do ar e vibrações causadas pelas explosões que elevam o desgaste e a humilhação. Aparecem ainda logotipos e máquinas, mas continua uma gigante desconhecida que os moradores dos reassentamentos, para não dizer do distrito, perguntam de quem é a Vale S/A. Muitos acreditam ser uma estatal brasileira, afinal, a fusão do Estado com o capital privado tornou mais obscura a relação. Uma Sociedade Anônima que faz com que não apareça um rosto, quem são os donos? E até mesmo para acessar um trabalhador de qualquer nível

${ }^{110}$ Chefe. 
administrativo, seja coordenador, gerente, diretor, parece não ser possível, dada a distância na relação entre as pessoas que trabalham na empresa dos moradores dos reassentamentos. Como disse Kurz (2002) não só a técnica e o conteúdo material da produção se modificaram nesse processo, mas também as formas elementares das relações sociais foram sacudidas por uma transformação longa, dolorosa e turbulenta.

Então retomamos aqui o massacre aos superiores da Companhia Carbonífera que apresentamos no primeiro capítulo, em que, num ápice após perderem mais vidas de amigos e familiares, moradores do distrito enfrentaram aqueles que personificavam a empresa, o capital. Quando relatou aquele episódio, meu interlocutor disse: um dia poderá acontecer isso com a Vale, porque está a fazer barulho (ARNALDO, 2017). Qual é o barulho? Este senhor argumentou que o barulho é não oferecer trabalho, enquanto o carvão pertence ao povo, mas fica com a Vale. Ou seja, a questão já não são os acidentes, mas a degradação em que vivem e que aparece como resultado da falta de dinheiro, por não terem trabalho, por terem perdido suas formas de reprodução e, nesse momento, o que difere de outros momentos é marcado principalmente pela perda do acesso à terra fértil dada a exploração a céu aberto.

Nesse sentido, relatamos um episódio em que, como num ápice diante da barbárie, alguns moradores do distrito ocuparam a área de concessão da Vale S/A em outubro de 2018, reivindicando a paralização das atividades da empresa e justificaram a ação como repúdio à poluição que já não podem mais suportar. Diante dessa empresa sem rosto, os vídeos divulgados na internet registraram esses manifestantes atirando pedras nas imensas máquinas que operam nessa área de exploração e seguem impedindo que funcionários entrem na área de operação.

\section{3. "Somos pessoas, deveriam nos considerar".}

Falaram-me que no Brasil tem uma outra parte que tem tradição: tem curandeiros, tem tradição... é verdade?

Essa pergunta foi feita por um atual morador de Cateme e antigo morador do bairro Chipanga, o Sr. Lionel. Ele trabalhou entre 1978 e 1987 na CARBOMOC e atualmente é reformado. Diz que trabalhou como pedreiro e se demonstrou bastante orgulhoso do conhecimento que acumulou na construção de tantas casas, inclusive na cidade de Tete. O conhecimento como pedreiro o ajudou a perceber a futura disposição das casas de Cateme e por isso solicitou (e foi atendido) ficar no fim do reassentamento, sem vizinho 
em um dos lados da casa, onde teria área para construir futuramente ou criar animais, ainda que as casas desse reassentamento já sejam um tanto distantes uma das outras, devido à área que seria para as machambas, caso houvesse o conjunto de elementos que as tornassem possíveis.

O Sr. Lionel queria saber se no Brasil tem feiticeiros. Que feiticeiros? Que tradição? Em quantas partes e quais são essas partes que esse senhor divide o Brasil ao perguntar se em uma delas tem tradição? E na(s) outra(s) parte(s) tem o que? O que tem no lado de lá?

Entre os sons das galinhas, porcos, o bater do pilão que uma senhora prepara amendoim, o som das crianças que brincam na terra e o vento contínuo que atravessa o reassentamento, ele segue contando em português sobre o período em que trabalhou na Odebrecht, naquela primeira fase da operação, na construção das casas do reassentamento e, como pedreiro, denuncia: foram construídas sem vigas! Ele trabalhou também na etapa de instalação das minas da mineradora Vale S/A, ou seja, onde estavam os bairros em que viviam antes dos reassentamentos ${ }^{111}$, um trabalho que, como já dissemos, durou dois anos. Então ele explicou de onde vem a dúvida sobre os feiticeiros do Brasil:

Estavam aqui dois brasileiros: Valdo e Inoque. Inoque disse-me assim:

Aquele ali está na cidade agora, mas aquele ali é grande feiticeiro! Porque viveu muito no campo. - Referindo-se a Valdo, o encarregado geral. Ele [Valdo] basta dizer que “ei, gente!”. Toda a gente fica calada.

Gente, eu não quero ver uma pessoa com uma botija de diesel a roubar. Quando eu ver uma pessoa, vou mandar para rua hoje. Eu não quero ver! [Valdo]

Ninguém fazia, basta ele dizer. Bastava fazer ameaças: "eu vou te mandar à rua". Você sozinho pode tremer. Ele nem batia em pessoa, só ele basta falar com a pessoa, o coração bate logo! Então Inoque disse:

Aquele ali é brasileiro também, ele está na cidade. Nós somos brancos, mas aquele ali é feiticeiro porque viveu muito no campo.

Mesmo [sendo] brasileiro igual! Basta dizer que "Valdo está a vir”, logo tens que arrumar uma forma de resolver a situação. Por isso eu perguntei se no Brasil tem

\footnotetext{
${ }^{111}$ Quando questionado se essa foi a etapa de derrubada das casas em que eles viviam e abertura do terreno para a instalação das minas, assim como outros que também trabalharam nas obras, ele não confirmou claramente em palavras, mas sinalizou com o levantar das sobrancelhas e o seguido silêncio, sinais comuns quando se concorda com o que está sendo dito, ou seja, "sim".
} 
tradição. Ah... Valdo!? Basta chegar aqui: toda a gente com o coração a bater. Aquele ameaçava muito. Esse era homem de droga!

Que droga?

De valor. Para ele ter muito valor e quando falar, toda a gente temer. Por ele ter valor, basta ele falar e ninguém vai rejeitar a ele. Se está errado ou está bom, toda a gente a responder sim em tudo.

- $\quad$ Tem que fazer isso, isso e isso. [Valdo]

- $\quad$ Tá bem, tá bem, tá bem. [Todos]

- $\quad$ Isso tem que acabar hoje. [Valdo]

Então: temos que trabalhar até a noite, porque o chefe mandou. Ele chega:

-Meus senhores, por favor. Seu líder, eu quero falar com muita gente hoje. Hoje mesmo eu tenho que falar com muita gente.

O líder já começa a tremer, andar de lados para o outro. Aí em poucas horas está cheio lá de pessoas. Ele fala e todos:

- Aquele falou coisa verdade, temos que fazer isso.

Enquanto ele estava a mentir... Sabe droga? Aquilo é droga. Não são todos os curandeiros que conhecem isso. Apenas certas pessoas... curandeiros antigos conhecem. Valdo? Bate o coração. E só está a falar. Voz ameaçante mesmo. Parece um presidente."

A conversa pode parecer confusa e passa por objetividades e subjetividades, pelo que é posto como tradicional aparentemente por não enquadrar-se nas relações da forma capitalista, por relações de feitiço. Num entrelaçado de coisas que vão além da materialidade, nebuloso. Tal estranhamento de minha parte é descrito pelo escritor Mia Couto ao compartilhar sobre suas experiências por Moçambique e seus momentos em que a oralidade se faz presente na contação de histórias. Então, numa reunião de textos que registram algumas de suas falas em conferências, publicados no livro "E se Obama fosse africano?" ele diz que: as duas partes em mim exigiam um médium, um tradutor. E segue:

Aquele momento agia em mim de maneira contraditória: por um lado, me aconchegava, por outro me excluía. Eu não podia partilhar por inteiro daquela conversa entre deuses e homens. Porque eu estava já carregado de Europa, minha alma já bebera de um pensamento. E os meus mortos residiam num outro chão, longínquo e inacessível. (COUTO, 2009: 124)

Talvez essa citação coubesse inclusive em outro momento na dissertação, em que a relação do mundo dos vivos e dos mortos esteja mais marcado, mas esse momento da conversa com o Sr. Lionel foi um desses momentos de não compreender como o outro 
está compreendendo a situação narrada, de ambos os lados, por não compreendermos como o outro entende feitiço. De qualquer maneira, o que parece é que para ele, o medo do feitiço, desse desconhecido, faz com que as pessoas obedeçam ao que o sujeito burguês ordena.

Viemos desde o início da dissertação confrontando duas lógicas que organizam as relações, sendo que marcadamente a lógica do capital é nosso principal interesse em perceber como ele territorializa. Percebemos que o processo de territorialização do capital atravessa e desestrutura as organizações sociais que precedem, então essa outra lógica e que a partir daquilo que compreendemos da exposição dos interlocutores e da revisão bibliográficas apresentamos como uma organização social que tem relação com o divino. Ao longo desse processo, mecanismos de dominação e controle dos corpos foram utilizados no processo de formação e reificação de conceitos e categorias capitalistas que em diferentes momentos o sujeito iluminista burguês tenta organizar tais relações a partir de sua racionalidade.

No primeiro capítulo, falamos sobre a imposição da autoridade administrativa no período colonial, em detrimento da autoridade que precedia. Cuahela (1996) definiu como autoridade tradicional e criticamos o termo, por compreendermos que essa própria autoridade por ele apresentada já tenha atravessado mudanças no processo histórico. No entanto, fazemos o questionamento se na organização das relações sociais a imposição do fetiche da mercadoria se deu de forma total e se extinguiu a lógica peculiar que não condiz com a forma capitalista, pois acreditamos que diálogos como esse demonstram uma compreensão de que o que organiza as relações podem ter origem em uma relação de totalidade abstrata e que pode ser desconhecida para ele. Nesse sentido, do ponto de vista de Lionel, o que será que os encarregados acessam e que ordena a organização das pessoas, de modo que eles tenham o poder de fazer o coração das pessoas dispararem?

Chama-nos atenção ainda o fato de Lionel comparar esses homens de negócios à figura de um presidente. Parece-nos que o Sr Lionel reconhece na instituição que é o Estado aquela que ordena, organiza as atividades que são executadas e assim, compara a personificação do Estado que é o presidente, e que aparentemente associa a uma figura autoritária, aos encarregados da empresa Odebrecht, atores que aparecem no processo de territórialização do capital para a sociedade produtora de mercadorias. É pelo medo do desconhecido e que aparece de forma autoritária que as pessoas parecem obedecer e entram na forma social. 
Apresentamos esse relato para expor uma forma de coerção ao trabalho utilizada, ou ao menos narrada, no contexto contemporâneo. E questionamos se essa estratégia seria maneira de substituir o uso da força física que não é permitido visto que, nesse caso, com o uso do medo do feitiço não há jurisdição que impeça? Ou seria apenas uma maneira que aos olhos deles aparece como diversão ao usar métodos que somente naquela situação são aplicáveis? Ou ainda relações que o próprio Lionel compreendeu dessa forma sem que de fato tivesse sido intencional? Não temos como saber o que Inoque pensa, mas o medo como método de coerção pareceu eficaz tanto quanto a explícita coerção pela violência física, pois a situação coloca Valdo como um sujeito a ser temido e a ele obediente.

O senhor Valdo personifica o capital e ele disciplina para o trabalho. Ele é colocado como feiticeiro pelo seu par que testemunha e legitima esse poder, como maneira de dominar por outras determinações essas pessoas e os colocam como trabalhadores na relação, ou seja, usa do medo do feitiço para impor seu desejo de organizar a relação para a produção de mercadorias dentro da racionalidade empresarial.

Ainda que tenha havido outros momentos de imposição ao trabalho e que faça com que meus interlocutores diferenciem o trabalho abstrato de outras atividades em que transformam matéria prima, mas sem produzir valor e por mais que meus interlocutores reivindiquem trabalho por necessitarem de dinheiro, sobretudo nesse momento em que a forma de reprodução pelas machambas foi dificultado, essa história que me foi narrada parece revelar que ainda há o estranhamento dessa relação capital-trabalho, não há uma naturalização dessa relação que, conforme apresentamos nessa dissertação, foi construída historicamente.

A jornalista Rossi (2015) entrevistou Mia Couto quando fez sua pesquisa em Moçambique. E uma das ideias apresentadas nos abre uma possibilidade para esse debate dos sujeitos na formação da relação capital e por onde podemos pensar no processo de reificação. O escritor, que também é biólogo, é diretor da empresa Impacto - projectos $e$ estudos ambientais. Ele compartilhou com a jornalista sobre uma situação na Província de Cabo Delgado, no norte de Moçambique, onde atualmente são crescentes as concessões para mineração. Na situação que ele se refere, uma empresa de gás mobilizava trabalhadores e então ele explica que essas pessoas não sabiam o que era uma companhia, uma empresa e era a primeira vez que assinavam um contrato e tinham um trabalho assalariado. Por ele ser da empresa de consultoria, recebeu uma reclamação sobre os trabalhadores que faltavam ao trabalho e por isso a empresa tinha a intenção de trocá-los por trabalhadores moçambicanos do sul, onde está a capital moçambicana. Geralmente os 
moçambicanos do sul são apontados como pessoas mais preparadas para o trabalho. Essa diferença regional no processo de modernização no país foi apresentada por Couto de forma identitária, em que ao contratar migrantes, a empresa poderia criar problemas étnicos, pois iria sugerir que alguns grupos servem para uma determinada atividade enquanto outro grupo não serve e isso iria supor hierarquias. No entanto, é válido lembrar que o sul tem maiores centros urbanos e relações de trabalho podem estar mais naturalizadas.

O fato é que diante da reclamação, o escritor e biólogo foi conversar com o chefe da comunidade:

Eu fui lá e falei com um desses que era chefe da comunidade. E ele disse: 'Não, é mentira, eu sempre trabalhei. Eu fui segunda-feira. Terça-feira o mar estava bom, então eu mandei o meu cunhado trabalhar na companhia. Quarta-feira mandei a minha prima. Quinta-feira mandei a minha mulher.' Ele disse: 'eu sempre estive presente'. Significa que ele se define numa identidade familiar. (COUTO in ROSSI, 2015: 359)

Trata-se de uma situação que ocorreu noutra Província, mas leva-nos a refletir sobre uma individualização dos sujeitos não formada. E então como podemos pensar nessa identidade familiar?

No livro Muntuísmo, o filósofo Ezio Bono reflete sobre a ideia de pessoa na filosofia africana. Primeiramente esclarecemos que Muntuísmo é um neologismo formado a partir da palavra Muntu, que em língua bantu significa pessoa, ideia central do livro. $\mathrm{O}$ autor faz nesse livro uma apresentação da ideia de pessoa com base em outros autores, entre eles missionários como Placide Temples que escreveu sobre filosofia Bantu e outros filósofos africanos, dentre eles o moçambicano Ngoenha.

Das formulações que Bono apresentou, nos parece bastante central a relação da procriação como elemento que dá unidade e sentido a esse grupo de pessoas. Para o filósofo ruandês Alexis Kagame a finalidade do homem é determinada pela procriação que permite a continuação da linhagem. Resulta então que morrer sem descendência é a maior desgraça (BONO, 2015 :30). Já para o congolês Vincent Mulago ter muitos filhos é sinônimo de poder e para ele não existem pessoas isoladas, nem famílias isoladas, nem vidas isoladas, todos estão conectados. Já para o queniano John Mbiti, a desgraça em não ter filhos está no fato de que ninguém fará viver o defunto após a morte, pois enquanto o indivíduo morto for chamado pelo nome ele não está completamente morto.

Em África, o indivíduo não pode existir sozinho, apenas no seio da comunidade, sendo parte de um todo. Não basta nascer, é necessário ser 
integrado na sociedade através de ritos de iniciação. Tudo quanto diz respeito ao indivíduo diz respeito ao grupo inteiro. Para clarificar a natureza deste sentimento fundamental de pertença, Mbiti introduz um princípio, depois convertido num dos axiomas mais famosos e citados da filosofia africana: $e u$ sou porque nós somos e, porque somos, então sou ${ }^{112}$ (BONO, 2015: 64)

Compreendemos a formulação como um entendimento em que o indivíduo não é suficiente sozinho, ele é um ser relacional, não autonomizado. E fazemos esse caminho para a análise, pois nos dá elementos que nos aproxima da compreensão que converge com o trecho de Mia Couto (2009) que expusemos. Em outro texto do mesmo livro, o autor fala sobre palavras do vocabulário europeu que não tem tradução nas línguas locais, as línguas bantus, e vice e versa. A apresentação é para falar dos mundos que existem atrás da linguagem. E então ele narra situações que presenciou em que algumas palavras não tinham tradução para as línguas locais. Dentre os termos que ele exemplificou destaco o termo pobre. Ele diz que em algumas línguas de Moçambique, pobre é chamado de chisiwana, que quer dizer órfão. E segue:

O pobre não é apenas o que não tem bens, mas é sobretudo o que perdeu a rede das relações familiares que, na sociedade rural, serve de apoio à sobrevivência. $\mathrm{O}$ indivíduo é pobre quando não tem parentes. A pobreza é solidão, a ruptura com a famílias. Os consultores internacionais, especialistas em elaborar relatórios sobre a miséria, talvez não tenham em conta o impacto dramático da destruição dos laços familiares e das relações sociais de entreajuda. Nações inteiras estão se tornando órfãs, e a mendicidade parece ser a única via de uma agonizante sobrevivência (COUTO, 2009: 22 - grifo nosso).

$\mathrm{O}$ trecho em destaque expressa uma particularidade do entendimento das relações familiares na sociedade rural. Entendemos que o apoio à sobrevivência esteja relacionado à produção de alimentos, que é produzido e consumido coletivamente entre os membros da família quando tem acesso à terra com as condições necessárias, ainda que seja uma relação que complemente a forma da reprodução pelo salário. Trata-se de uma definição de pobreza e consequentemente de riqueza que não tem no trabalho a sua origem, nem na capacidade de comprar o trabalho de outro, em que a riqueza tem uma materialidade acessada pelo dinheiro e o dinheiro vem do trabalho, na forma de salário e o salário é pago individualmente.

\footnotetext{
${ }^{112}$ Esse é o princípio da filosofia Ubuntu que foi aplicado na política de reconciliação na África do Sul, por exemplo, visando superar erros do apartheid, cujo autor de referência foi sobretudo Desmond Tutu. "A comissão teve a tarefa de processar os criminosos do regime do apartheid, não para puni-los, mas para que com a plena confissão dos seus delitos e com o perdão da parte dos ofendidos, pudessem ser reinseridos na comunidade" (BONO, 2015: 65).
} 
Sendo assim, no caso da pesquisa que aqui apresentamos, a destruição dos laços familiares e a desestruturação dessa entre-ajuda são compreendidas como o processo de expropriação que leva à mendicidade, ou seja, à pobreza. Ainda nesse jogo de palavras, o estado de mendicidade parece ser entendido por Couto (2009) como uma relação que ocorre na cidade, ou a partir da desestruturação dessa sociedade rural.

A sociedade do trabalho autonomiza as relações, individualizando os sujeitos e padronizando as formas de sociabilidade que são mediadas pelo dinheiro. Para Kurz:

O moderno sujeito produtor de mercadorias, isto é, o sujeito do trabalho, da circulação, do conhecimento e do Estado passa a vigorar como "o ser humano" por excelência, sendo que a isso se liga a promessa metafísica de uma "autonomia e autorresponsabilidade" mediante a forma burguesa de agir e pensar (KURZ, 2010: 46).

Nessa lógica, em que a definição de ser humano, ou seja, de pessoa, passa pelas relações da forma valor, exclui socialmente da humanidade todos os indivíduos que, efêmera ou duradouramente, não podem (ou não podem mais) agir dentro dos limites do automovimento do sujeito automático. (KURZ, 2010: 50). Esses sujeitos estão excluídos do sistema por serem supérfluos a ele.

Então, retomamos o início do capítulo. Enquanto os homens mais velhos dos reassentamentos foram em outro momento da reprodução capitalista forçadamente retirados de suas práticas e mobilizados ao trabalho, eles eram úteis ao sistema pela força de trabalho. Ao mesmo tempo a relação familiar e as machambas permaneceram. Atualmente esses homens mais velhos tem o dinheiro da aposentadoria que dá uma mínima possibilidade para eles e suas famílias manterem a sociabilidade mediada por coisas. Por outro lado, atualmente os homens mais jovens vivem e acompanham o crescente processo de expropriação com a perda das terras férteis e menos possibilidades de trabalhos informais, ao mesmo tempo em que são tidos como supérfluos ao sistema e não tem trabalho para eles.

Aos olhos de quem exclui o processo histórico, essas pessoas desempregadas são colocadas na relação do self-made, ou seja, basta a disposição para o trabalho e então teriam dinheiro. A inconsistência desse argumento e dessa ilusão social-darwinista é contraposta pelas particularidades que o trabalho de campo revelaram e apresentamos nessa dissertação, pois o fracasso não pode ser entendido como um fenômeno individual, mas é próprio da sociedade produtora de mercadorias, tal como formulou Kurz (1993).

A desumanização das pessoas que não se inserem no sistema se faz percebida bruscamente nos reassentamentos. E então para encerrar esse ítem, lembramos um 
episódio em Cateme. No mesmo reassentamento onde conversei com o Sr. Lionel em que narrou o controle dos corpos pelo medo do feitiço e o controle desses corpos no sistema, numa conversa em que estivemos cercado de pessoas membros de sua família, foi também o reassentamento em que um jovem já um tanto embriagado (grosso, na maneira moçambicana de definir) numa tarde de sábado, tentou um diálogo com a pesquisadora estrangeira e branca. Esse jovem insistia na conversa quando não tinha abertura para isso, então colocou-se em embate e num ato que ganhou antipatia pelas pessoas que estavam ao redor, gritou mostrando seu crachá de funcionário da empresa Vale S/A:

- Eu sou pessoa!

Era o trabalho que o fazia sentir-se como pessoa, pois pelo trabalho ele estava inserido no sistema, mas ele era o único daquele grupo que trabalhava ao menos para a Vale S/A. Os demais enquadram-se naqueles que buscam maneiras de obter dinheiro e estão excluídos, supérfluos ao sistema. 


\section{Considerações finais}

O estudo da formação da categoria trabalho a partir do distrito de Moatize, em Moçambique, permitiu-nos acompanhar o longo processo de territorialização do capital e imposição dessa forma social naquela parte do continente africano. Ao jogarmos luz à violência do processo de expropriação, violência que o próprio processo histórico obscurece, acompanhamos a transformação da lógica e determinações fetichistas que organizavam as relações, os métodos de coerção e as privações que gradualmente foram impostas aos sujeitos que os levou a necessitar cada vez mais do dinheiro para mediação social.

Os métodos e a juridificação estatal para formação das categorias capitalistas atravessam as histórias particulares de famílias e indivíduos que atualmente residem nos reassentamentos da Vale S/A, de modo que os interlocutores em pesquisa de campo foram capazes de narrar a partir de suas experiências e oferecer elementos de uma importante parte esse processo.

A modernização das forças produtivas no setor da mineração provocou uma mudança histórica nas relações de trabalho em Moatize e na produção da mercadoria carvão. Ao olharmos para os moradores dos reassentamentos, compreendemos que há duas gerações de pessoas que tem funções distintas no sistema de reprodução capitalista.

A primeira geração, formada pelos mais velhos dos reassentamentos, viveu quando a extração do carvão no distrito era feita pela Companhia Carbonífera durante o regime colonial ou ainda pela CARBOMOC no pós colonial, durante o período socialista. No período colonial, a extração do carvão nas galerias subterrâneas colocava a necessidade de muitos trabalhadores e esses eram mobilizados inicialmente de forma explicitamente forçada, o chibalo, pois eles eram úteis e necessários para a produção da mercadoria. A Lei do Indigenato que, ao contrapor o que era entendido como vadiagem, obrigava principalmente os homens ao trabalho enquanto as mulheres permaneceram nas atividades domésticas e agrícolas, formando assim atividades complementares de reprodução: o trabalho assalariada com que pagariam impostos cobrados pelo regime colonial e outras necessidades que foram sendo formadas e a produção de alimentos nas machambas que era base da reprodução dessas famílias e também possíveis mercadorias.

Durante o auge da colonização (Hedges) que foi durante o Estado Novo português, o chibalo e o aumento de impostos foram estruturalmente retirando as pessoas das atividades agrícolas e das práticas que realizavam anteriormente. $\mathrm{O}$ aumento de impostos 
e a mudança do pagamento de renda que de gênero mudou para dinheiro colocaram a necessidade do trabalho assalariado, num processo violento de mobilização ao trabalho, ou seja, o processo de autonomização (Marx) dessa categoria capitalista. A expropriação aparece pela coerção ao trabalho para o outro e resultou no menor tempo disponível para as práticas no próprio contexto familiar.

No pós libertação, a coerção ao trabalho foi alterada em sua aparente finalidade. Enquanto anteriormente o trabalho estava para o outro, para o colonizador, nesse novo contexto as políticas estatais, agora de um Estado nacionalista, centralizador e que tem entre os objetivos a formação do Homem Novo, coloca a construção do Estado Nacional moçambicano como causa coletiva pelo esforço do trabalho. A modernização retardatária (Kurz, 1993) do país africano está lançada e baseada no marxismo leninismo, o desenvolvimento agrícola seria base para a industrialização que viria posteriormente, mas a crise que acometeu também o país não ocorreu. Um dos métodos de organização da produção e da força de trabalho durante o período dito socialista foi a política chamada de Operação Produção.

Os homens mais velhos que vivem nos reassentamentos que compõem o que chamamos de primeira geração atualmente encontram-se aposentados e esse é um elemento importante a ser considerado, pois, em meio a falta de trabalho e dinheiro nos reassentamentos, esse é um elemento que possibilita a mínima dignidade humana em meio à humilhação (Heidemann, 2004) a que foram empurrados. Diante da escassez atual, ao olhar para o período anterior argumentam: antes havia trabalho, hoje não há.

A segunda geração dos também moradores dos reassentamentos da Vale S/A já se apresenta em crise. Diferentemente da primeira geração, os que compõem essa segunda geração não são e nem terão condições de virem a se aposentar futuramente, pois atualmente não trabalham formalmente. Mesmo antes dos reassentamentos, para acessarem dinheiro tinham de realizar atividades já em grande competição, com a revenda de mercadorias ou daquilo que produziam com matéria prima coletada no próprio lugar, o que não precisava necessariamente de capital inicial, mas também não acumulava.

O período que antecede os reassentamentos, ou seja, quando essas pessoas viviam nos bairros Mithethe e Chipanga, havia machambas. Isso dava condição mínima para alimentação a partir daquilo que as mulheres produziam. E esse é um ponto importante na dissertação, pois a perda da machamba potencializa o estado de humilhação em que vivem essas pessoas que se tornaram supérfluas ao sistema e as coloca em estado de fome. A atividade nas machambas colocava as mulheres em coletividade e numa função que era 
importante para toda a família. Como consequência do processo histórico essa atividade é entendida socialmente como uma função da mulher. Ao perderem essa que é a sua principal atividade de reprodução, as mulheres sofrem a pressão social para que realizem a atividade e sofrem com o aumento da violência doméstica. Ao mesmo tempo, as mulheres tem menos possibilidades de vender a força de trabalho.

A modernização das forças produtivas alterou a forma de extração do carvão que de subterrânea passou a ser extraído a céu aberto. Por isso houve a remoção das pessoas de seu lugar de moradia e reprodução. Além disso, houve o cercamento das áreas que foram concedidas pelo Estado moçambicano para as multinacionais. Diferentemente da forma clássica em que Marx (1986) apresentou o processo de expropriação na Inglaterra com os cercamentos e a necessidade de venda da força de trabalho formou os trabalhadores para a indústria, nesse caso que apresentamos nessa dissertação é que os cercamentos potencializam a expropriação, no entanto essas pessoas não são úteis ao sistema e são excluídas da relação, num processo de grande sofrimento.

A terceira revolução industrial elevou a contradição do sistema a outros patamares, pois expropria pessoas mais velozmente ao mesmo tempo em que diminui a necessidade de trabalho humano na produção de mercadorias. E no mundo de expropriados a quantidade de força de trabalho disponível é abundante. Nessa competição pela busca de trabalho é selecionado aquele que tem as melhores qualificações e para os reassentados foi apresentada a condição mínima: ter a $12^{\mathrm{a}}$ classe, no entanto eles não tem, excluindoos da competição e assim sequer podem se candidatar ao trabalho. Estão excluídos, supérfluos.

O resultado tem sido a reivindicação por trabalho, por indenizações e a situação de humilhação agravada. Ao não ter a possibilidade de vender a força de trabalho, vendem o que podem e ao não ter mais o que vender, recorrem, inclusive, a roubos, mas argumentam: fomos roubados antes.

Na totalidade da reprodução da sociedade produtora de mercadorias, consideramos que a contradição pode ser apresentada por dois aspectos. Primeiramente a modernização das forças produtivas e que aparece com as máquinas mais modernas da mineração na operação de extração de carvão em Moatize, acelera a produtividade da mercadoria e consequentemente aumenta a necessidade de consumidores. O início das operações da mineradora Vale S/A, no início dos anos 2000, foi considerado dentro do que é apresentado como o período do boom das matérias primas. Os maiores consumidores da mercadoria carvão eram os países em processo de modernização retardatária e entre os 
países destacamos a Índia e China. Foi período em que outras multinacionais do setor também tiveram áreas concedidas para extração e um número crescente de outras empresas interessadas na atividade. Com isso o Estado moçambicano disponibilizou mais áreas para pesquisa e prospecção, mostrando-se disposto a conceder novas áreas para extração e que levaria a novos reassentamentos, pois essa é uma importante forma que o Estado moçambicano arrecada dinheiro, a mineração é fonte de divisas naquele país na periferia da periferia do sistema capitalista.

O fim desse boom das matérias primas pode ser pensado a partir dessa mesma representação das áreas de concessão realizada pelo Estado moçambicano, pois mesmo com tantas empresas pesquisando sobre os minerais disponíveis na Província de Tete, não resultou em novos contratos. Consideramos o desinteresse na mercadoria carvão como consequência da crise que culminou nos EUA nos anos 2008 e lentamente atingiu outros países e levou, por exemplo, à desaceleração da economia chinesa e consequentemente diminuiu o consumo de carvão. Esse desinteresse levou à políticas de desinvestimento por parte das empresas multinacionais e a venda de concessões, ou parte delas, para outras mineradoras.

A segunda contradição do sistema produtor de mercadorias pode ser apresentada também pelo capital fictício. Junto à Vale S/A outras empresas sobretudo empreiteiras passaram a atuar em Moçambique em atividades ligadas à essa multinacional para a construção da infraestrutura necessária à circulação da mercadoria carvão. Essas atividades foram financiadas por bancos, a princípio bancos estatais brasileiros: o Banco do Brasil e principalmente o BNDES.

Por serem países em diferentes momentos no processo de modernização, ou seja, por serem países desiguais, não simultâneos, é que tal relação foi possível. No entanto, para devolver o capital emprestado acrescido dos juros, é necessário que o carvão circule, que seja útil para o outro, afinal a mercadoria só realiza valor quando é vendida. Ao não ser vendida é prejuízo. É mais dívida. 


\section{Bibliografia}

ADAMO, Issufo, DAVIES, Robert, \& HEAD, Judith. Mão-de-obra moçambicana na Rodésia do Sul. Estudos moçambicanos n.2, pp. 59-72. 1981

ALENCASTRO, Luiz. Felipe. O trato dos Viventes: formação do Brasil no Atlântico Sul. São Paulo: Companhia das Letras. 2000

ALVES, Fabiano José L. O ProSAVANA e o desenvolvimento contraditório da agricultura em Moçambique. Monografia apresentada ao Departamento de Geografia da FFLCH-USP, São Paulo. 2016

AMIN, Samir. A caminho de uma nova crise estrutural do sistema capitalista. Porto: Afrontamento. 1978

AZEVEDO, Desirée de Lemos. Os melhores anos de nossas vidas: narrativas, trajetórias e trajetos de exilados brasileiros em Moçambique. São Paulo: Annablume: FAPESP. 2013

BANCO MUNDIAL \& IPEA. Ponte sobre o Atlântico: Brasil e África Subsaariana Parceria Sul-Sul para o crescimento. Brasília. 2011

BRAGANÇA, Aquino, \& FIRST, Ruth. Do chibalo à libertação da África Austral. Estudos Moçambicanos, $n^{\circ}$ 2. pp. 2-8. 1981

BRAGANÇA, Aquino \& LAUGHLIN, Bridget O'. O trabalho de Ruth First no Centro de Estudos Africanos - $O$ curso de desenvolvimento. Estudos Moçambicanos $\mathrm{n}^{\circ}$ 14. Pp. 113-126.1996

BRITO, Luís. Dependência colonial e integração regional. Estudos Moçambicanos, $\mathrm{n}^{\circ}$ 1 pp. 23-32. 1980

CADERNOS DO TERCEIRO MUNDO. Diálogo com emigrantes, pp. no 11. 97-98. 1979

CAHEN, Michel. Seis teses sobre o trabalho forçado no império português continental em África. Revista USP. 2015 - Disponível em:

http://www.revistas.usp.br/africa/article/view/126697/123692. Acesso realizado em: $23 / 10 / 2018$

CAPELA, José. Como as aringas de Moçambique se transformaram em Quilombos. Tempo, pp. 72-97. 2005. - Disponível em: http://www.scielo.br/pdf/tem/v10n20/05.pdf. Acesso realizado em: 23/10/2018

CASAL, Adolfo Yañez Antropologia e desenvolvimento: as aldeias comunais de Moçambique. Lisboa: Ministério da Ciência e Tecnologia: Instituto de Investigação Científica Tropical. 1996

CASTANHEIRA, José Pedro. O massacre de Moatize: testemunhos da explosão e da chacina em Moçambique, 34 anos depois. Revista Única, pp. 40-58. 2011 
CENTRO DE DOCUMENTAÇÃO ECONÔMICA. Valorização do carvão. Maputo: República Popular de Moçambique. 1977

CENTRO DE ESTUDOS AFRICANOS. O mineiro moçambiano: um estudo sobre a exportação de mão de obra em Inhambane. Maputo: Centro de Estudos Africanos, Universidade Eduardo Mondlane. 1998

COELHO, João Paulo Borges. Abrir a fábula: questões da política do passado em Moçambique. Revista Crítica de Ciências Sociais pp. 153-166. Coimbra. 2015

O início da luta armada em Tete, 1968-1969: a primeira fase da guerra e a reacção colonial. Maputo: Núcleo Editorial da UEM. 1989

Rainhas da Noite. Maputo: Ndjira. 2013

COSTA, Diogo Valença A. Ruth First e a história das ciências sociais em Moçambique: o "ouro negro" e o trabalhador migrante nas minas sulafricanas. Revista de Ciências Sociai, no 2 - pp.17-52. Fortaleza. 2015

COUTO, Mia. E se Obama fosse africano? - E outras interinvenções. Lisboa: Caminho. 2009

CUAHELA, Ambrósio. Autoridade Tradicional em Moçambique. Ministério da Administração Estatal - Núcleo de desenvolvimento administrativo. Projecto "Descentralização e autoridade tradicional". Brochura 1. 1996

DARCH, Colin. As publicações da FRELIMO: um estudo preliminar. Estudos moçambicanos, $\mathrm{n}^{\circ}$ 2. pp. 105-1020. 1981

FEIJÓ, João. Investimentos, assimetrias e movimentos de protesto na província de Tete. OMR. $\mathrm{N}^{\circ}$ 44. 2016

FIRST, Ruth. Subdesenvolvimento e trabalho migratório. Estudos Moçambicanos - pp. 2-8. 1980

FOÉ, Nkolo. África em diálogo, África em autoquestionamento: universalismo ou provincialismo? "Acomodação de Atlanta" ou iniciativa histórica? Educar em Revista, Curitiba, no 47. Pp.175-228. Brasil. 2013

GARCIA, Ana Saggioro, \& KATO, Karina. Políticas públicas e interesses privados: uma análise a partir do Corredor de Nacala em Moçambique. Caderno CRH, pp. 69-86. Jan/ Abr 2016

GARCIA, Ana Saggioro, KATO, Karina \& FONTES, Camila. A história contada pela caça ou pelo caçador? - Perspectivas sobre o Brasil em Angola e Moçambique. Políticas Alternativas do Cone Sul (PACS). 2013

GAUDEMAR, Jean Paul. Mobilidade do trabalho e acumulação do capital. Lisboa: Estampa. 1977

GEFFRAY, Christian. A causa das armas: antropologia da guerra contemporânea em Moçambique. Edições Afrontamento. 1991 
HARVEY, David. A produção capitalista do espaço. São Paulo: Annablume. 2005

HEAD, Judith. A Sena Sugar Estates e o trabalho migratório. Estudos moçambicanos $\mathrm{n}^{\mathrm{o}} 1$, pp. 53-72. 1980

HEAD, Judith, \& MANGHEZI, Alpheus. O trabalho forçado por quem viveu: entrevistas. Estudos Moçambicanos n², pp. 23-32. 1981

HEDGES, David. História de Moçambique, Volume 2: Moçambique no auge do colonialismo, 1930-1961. Maputo: Livraria Universitária. 1999

HEIDEMANN, Dieter. Os migrantes e a crise da sociedade do trabalho: humilhação secundária, resistência e emancipação. Em: Migrações: discriminação e alternativas. pp. 25-39. Serviço Pastoral dos Migrantes. Paulinas. 2004

HEIDEMANN, Heinz Dieter, TOLEDO, Carlos de Almeida, \& BOECHAT, Cássio Arruda. O trabalho no Brasil: traçado interpretativo de sua história de formação e de sua crítica. Estudos Avançados - USP, p.55-67. 2014

HENRIQUE, Arnaldo. FACOTRAV - Antigo combatente está ausente! Tempo, pp. 67. $1989-\quad$ Disponível em: http://www.mozambiquehistory.net/politics/veterans/19890820_facotrav.pdf. Acesso realizado em 23/10/2018

HUMAN RIGHTS WATCH. O que é uma casa sem comida? O boom da mineração em Moçambique e o reassentamento. EUA: HRW. 2013

INE. Estatísticas do distrito de Moatize. Instituto Nacional de Estatística. 2010

JARDIM, Marta Denise R. Cozinhar, adorar e fazer negócio: Um estudo da família indiana (hindu) em Moçambique. Tese de doutorado em Ciências Sociais. Departamento de Antropologia - IFCH/ UNICAMP. Campinas. 2006

KURZ, Robert. A ascensão do dinheiro aos céus. Revista Krisis, n.16/17, 1995. Disponível em: http://www.obeco-online.org/rkurz101.htm. Acesso realizado em $24 / 10 / 2018$

Dinheiro sem valor: linhas gerais para uma transformação da crítica da economia política. Lisboa: Antígona. 2014

. O colapso da modernização: da derrocada do socialismo de caserna à crise da economia mundial. Rio de Janeiro: Paz e Terra. 1993

O curto verão de uma teoria do século XX. Folha de São Paulo. 1996

- Disponível em: https://www1.folha.uol.com.br/fsp/1996/4/21/mais!/11.html. Acesso realizado em 23/10/2018

Poder Mundial e dinheiro mundial: crônicas do capitalismo em declínio. Rio de Janeiro: Consequência. 2015

- Razão Sangrenta: ensaios sobre a crítica emancipatória da modernidade capitalista e de seus valores ocidentais. São Paulo: Hedra. 2010 
LEITE, Ana Carolina. A modernização do Vale do Jequitinhonha mineiro e o processo de formação do trabalhador "boia-fria" em suas condições regionais de mobilização do trabalho. São Paulo: Dissertação de mestrado apresentada ao Departamento de Geografia da FFLCH- USP. 2010

LÊLIN, Vladmir. I. O imperialismo: fase superior do capitalismo. Campinas: Unicamp. 2011

MAIA, Antonio. A. Mudanças socio-culturais entre os nyungwe do Vale do Zambeze: resistências, rupturas e continuidades na estrutura social. São Paulo: Departamento de Antropologia. FFLCH/ USP. 2015

MANDAMULE, Uacitissa. Discursos à volta do regime de propriedade da terra em Moçambique. Observatório do Meio Rural. 2015

MARTINS, José de Souza. O vôo das andorinhas: migrações temporárias no Brasil. Em Não há terra para plantar neste verão (o cerco das terras indígenas e das terras de trabalho no renascimento político do campo) - pp. 45-61. Petrópolis: Vozes. 1986

MARX, Karl. O capital: crítica da economia política. Livro Primeiro. Tomo II. São Paulo: Livro I Nova Cultural (série: "Os economistas"). 1986

O capital: crítica da economia política. Livro Terceiro. Tomo I. São Paulo: Livro I Nova Cultural (série: "Os economistas"). 1986

MATOS, E. A. Desterritorialização e reterritorialização das comunidades atingidas pela exploração do carvão mineral em Moatize, Moçambique. Tese de doutorado apresentada no Instituto de Geociências da UFRGS. Porto Alegre: IGEO/ UFRGS. 2016

MAUVILO, Antonio. Trabalhadores da extinta Carbomoc recebem indemnizações. ANFP, 6. Maputo. 2007

MBEMBE, Achille. As formas africanas de auto-inscrição. Estudos Afro-Asiáticos, pp. 171-209. 2001

MIGUEL, Inês Domingos S. A Companhia Carbonífera de Moçambique: evolução sócio-histórica no período 1950-1973. Tese para a obtenção do título de mestre em estudos africanos. Universidade do Porto. Porto. 2009

MINISTÉRIO DA ADMINISTRAÇÃO ESTATAL. Perfil do distrito de Moatize Província de Tete. Direcção Nacional da Administração Local. 2005

MOREIRA, N. Moçambique: dez anos depois. Cadernos do Terceiro Mundo, VIII. $\mathrm{n}^{\mathbf{o}}$ 79. p.25-29. 1985

MOSCA, João, \& Selemane, Tomás. El dorado Tete: os mega projectos de mineração. Maputo: Centro de Integridade Pública (CIP). 2011

MOURA, M. Luiz Felipe de Alencastro: o observador do Brasil no Atlântico Sul. Entrevistadora: Mariluce Moura. Revista Fapesp. Edição 188 de 2011. Disponível 
em: $\quad$ http://revistapesquisa.fapesp.br/2011/10/31/luiz-felipe-de-alencastrooobservador-do-brasil-no-atlantico-sul/. Acesso realizado em 23/10/2018

MUNGÓI, Cláudio. A. Desenvolvimento Regional no Vale do Zambeze: Moçambique em perspectiva. Revista de Geopolítica, Ponta Grossa - PR, pp. 33-45. 2010

NEGRÃO, José. O acesso à terra pela mulher rural: cinco sistemas de direitos consuetudinários. PNUD. Relatório Nacional de Desenvolvimento Humano. 2000

Editores. 2006

Cem anos de economia da família rural africana. Maputo: Texto

. Sistemas costumeiros da terra em Moçambique. Em SANTOS, \& TRINDADE, Conflito e transformação social: uma paisagem das justiças em Moçambique. Pp. 1-43. Maputo/ Coimbra: CEA/ CES. 2000

NEWITT, Malyn. História de Moçambique. Portugal: Publicações Europa-América. 1997

NGOENHA, Severino Elias. Filosofia Africana - das independências às liberdades. Luanda: Paulinas. 2014

OLIVEIRA, Francisco. Elegia para uma Re(li)gião: SUDENE, Nordeste.

Planejamento e conflito de classes. Rio de Janeiro: Paz e Terra. 1993

OSÓRIO, Conceição \& SILVA, Teresa Cruz. Corporações econômicas e expropriação: raparigas, mulheres e comunidades reassentadas no distrito de Moatize. Maputo: WLSA Moçambique. 2017

QUEMBO, Carlos Domingos. Poder do poder: Operação Produção e a invenção dos "improdutivos" urbanos no Moçambique socialista, 1983-1988. Maputo: Alcance. 2017

RAFFESTIN, Claude. Por uma Geografia do Poder. São Paulo: Ática. 1993

REPÚBLICA DE MOÇAMBIQUE. Contrato mineiro relativo a concessão mineira da mina de carvão de Moatize. Maputo: Ministério dos Recursos Minerais. 2007

REPÚBLICA FEDERATIVA DO BRASIL. Acordo de Cooperação e Facilitação de Investimentos (ACFI) entre o Governo da República Federativa do Brasil e o Governo da República de Moçambique. 2015 - Disponível em: http://www.itamaraty.gov.br/pt-BR/notas-a-imprensa/8511-acordobrasilhttp://www.itamaraty.gov.br/pt-BR/notas-a-imprensa/8511-acordo-brasilmocambique-de-cooperacao-e-facilitacao-de-investimentos-acfi-maputo-30-demarco-de-2015mocambique-de-cooperacao-e-facilitacao-de-investimentos-acfimaputo-30-dehttp://www.itamaraty.gov.br/pt-BR/notas-a-imprensa/8511acordo-brasil-mocambique-de-cooperacao-e-facilitacao-de-investimentos-acfimaputo-30-de-marco-de-2015marco-de-2015. Acesso realizado em 23/10/2018

RIO DOCE MOÇAMBIQUE. Estudo de Impacto Ambiental do Complexo Industrial de Moatize. Ministério de Recursos Minerais. 2006 
RODRIGUES, Eugênia. As donas de prazos do Zambeze: políticas imperiais e estratégias locais. s/d Disponível em:

http://www.humanas.ufpr.br/portal/cedope/files/2011/12/As-donas-de-

prazoshttp://www.humanas.ufpr.br/portal/cedope/files/2011/12/As-donas-de-prazos-

do-Zambeze-Pol\%C3\%ADticas-imperiais-e-estrat\%C3\%A9gias-locais-

Eug\%C3\%A9nia-Rodrigues.pdfdo-Zambeze-Pol\%C3\%ADticas-imperiais-e-

estrat\%C3\%A9gias-

locaishttp://www.humanas.ufpr.br/portal/cedope/files/2011/12/As-donas-de-prazos-

do-Zambeze-Pol\%C3\%ADticas-imperiais-e-estrat\%C3\%A9gias-locais-

Eug\%C3\%A9nia-Rodrigues.pdfEug\%C3\%A9nia-Rodrigues.pdf. Acesso realizado em $23 / 10 / 2018$

RODRIGUES, Maria Eugênia. Cipaios da Índia ou soldados da terra? Dilemas da naturalização do exército português em Moçambique no século XVIII. História: questões \& debates, pp.57-95 UFPR. Curitiba. 2006

ROSSI, Amanda. Moçambique, o Brasil é aqui. São Paulo: Record. 2015

SCHOLZ, Roswitha. A nova crítica social e o problema das diferenças. Tradução de Lumir Nahodil e Boaventura Antunes. 2004 - Disponível em http://obeco.planetaclix.pt/roswitha-scholz3.htm. Acesso realizado em 23/10/2018

Crítica da dissociação-valor e teoria crítica. Exit! $n^{\circ}$ 14. 2017 Disponível em: http://www.obeco-online.org/roswitha_scholz28.htm. Acesso realizado em 23/10/2018

Cristóvão Colombo Forever? Para a crítica das actuais teorias da colonização do "Colapso da modernização. 2016. - Disponível em: http://www.obeco-online.org/roswitha_scholz24.htm. Acesso realizado em $23 / 10 / 2018$

O Valor é o homem: teses sobre a socialização pelo valor e a relação entre os sexos. Novos Estudos - CEBRAP, no 45, pp.15-36. 1996 Disponível em http://www.obeco-online.org/rst1.htm. Acesso realizado em 23/10/2018

SECRETARIA DO ESTADO DO CARVÃo E HIDROCARBONETOS. Programa de Carvão. República Popular de Moçambique. 1984

SELEMANE, Tomás. Questões à volta da Mineração em Moçambique - Relatório de Monitoria das Actividades Mineiras em Moma, Moatize, Manica e Sussundenga. CIP. 2010

. Tete e Cateme: entre a implosão do El Dorado e a contínua degradação das condições de vida dos reassentados. Observatório do Meio Rural, p. n 45.2016

SERRA, Carlos. História de Moçambique - Volume I. Maputo: Imprensa Universitária. 2000 
SINE, Babakar. Imperialismo e teorias sociológicas de desenvolvimento. Lisboa: Moraes. 1976

SPACACHIERI, Marly. Os achicunda da África oriental portuguesa: escravosguerreiros a serviço da administração colonial e dos senhores dos prazos da Coroa, entrelaços e imprescindíveis à existência da sociedade mozungo. Anais do XXVI Simpósio Nacional de História, pp.1-15. 2011

TOLEDO, Carlos de Almeida A região das Lavras Baianas. São Paulo: Tese de Doutorado apresentada ao Departamento de Geografia da Universidade de São Paulo. 2008

TOLEDO, Carlos de Almeida \& BOECHAT, Cássio Arruda. Mobilização do trabalho e o estudo da região. Boletim Campineiro de Geografia, v.2, n.3. p. 448-464. 2012

VALE. Brasil e Moçambique assinam acordo de estímulo a investimento. 10 de abril de 2015. Disponível em:

http://www.vale.com/brasil/PT/aboutvale/news/Paginas/brasilmocambiquehttp://www.vale.com/brasil/PT/aboutvale/news/Paginas/brasilmocambique-acordo-estimulo-investimentos.aspxacordo-estimuloinvestimentos.aspx. Acesso realizado em 24/10/2018

. Vale conclui Project Finance do Corredor Logístico de Nacala. 23 de março de 2018. Disponível em:

http://www.vale.com/brasil/PT/aboutvale/news/Paginas/vale-concluiprojecthttp://www.vale.com/brasil/PT/aboutvale/news/Paginas/vale-concluiproject-finance-do-corredor-logistico-de-nacala.aspxfinance-do-corredorlogistico-de-nacala.aspx. Acesso realizado em 23/10/2018

WUYTS, Marc. Economia política do colonialismo português em Moçambique. Estudos Moçambicanos, pp. 9-22. 1980

Sites de notícias:

DW. Rio Tinto deixa exploração de carvão e arrefece expectativas em Moçambique. 01 de agosto de 2014. Disponível em: https://www.dw.com/pt-002/riotintohttps://www.dw.com/pt-002/rio-tinto-deixa-explora\%C3\%A7\%C3\%A3ode-carv\%C3\%A3o-e-arrefece-expectativas-em-mo\%C3\%A7ambique/a17827221deixa-explora\%C3\%A7\%C3\%A3o-de-carv\%C3\%A3o-e-arrefeceexpectativashttps://www.dw.com/pt-002/rio-tinto-deixaexplora\%C3\%A7\%C3\%A3o-de-carv\%C3\%A3o-e-arrefece-expectativas-emmo\%C3\%A7ambique/a-17827221em-mo\%C3\%A7ambique/a-17827221.

Acesso realizado em 23/10/2018

INFOMONEY. Minério de ferro pode volta para US\$ 50 e Brasil está entre os responsáveis pela derrocada. 29 de novembro de 2017 de novembro de 2017. Disponível em: https://www.infomoney.com.br/mercados/acoes-e- 
indices/noticia/7114644/minerio-ferro-pode-voltar-para-brasil-estaentrehttps://www.infomoney.com.br/mercados/acoes-eindices/noticia/7114644/minerio-ferro-pode-voltar-para-brasil-esta-entreresponsaveis-pelaresponsaveis-pela. Acesso realizado em 23/10/2018

JORNAL NOTÍCIAS. Polícia dispara balas reais contra um cidadão indefeso e matao em Tete. 14 de julho de 2017. Disponível em: http://pda.verdade.co.mz/nacional/62787-policia-dispara-balas-reais-contraumhttp://pda.verdade.co.mz/nacional/62787-policia-dispara-balas-reais-contraum-cidadao-indefeso-e-mata-o-em-tetecidadao-indefeso-e-mata-o-em-tete. Acesso realizado em 24/10/2018

\section{. UEM atribui honoris causa a Aquino de Bragança e Ruth}

First. 29 de agosto de 2013. Disponível em: http://www.jornalnoticias.co.mz/index.php/recreio-e-divulgacao/1822uemhttp://www.jornalnoticias.co.mz/index.php/recreio-e-divulgacao/1822-uematribui-honoris-causa-a-aquino-de-braganca-e-ruthfirst.html?device=desktopatribui-honoris-causa-a-aquino-de-braganca-e-ruthfirst.html?device=desktop. Acesso realizado em 23/10/2018

JORNAL VERDADE. Moçambique já foi auto-suficiente em farinha de milho, arroz, laranja... antes da independência. 31 de maio de 2016. Disponível em: http://www.verdade.co.mz/tema-de-fundo/35-

themadefundo/58114http://www.verdade.co.mz/tema-de-fundo/35-

themadefundo/58114-mocambique-ja-foi-auto-suficiente-em-farinha-de-milhoarroz-laranja-antes-da-

independencia?fb_comment_id=1024073184351382_1024296200995747

f5911f16bbdcfcmocambique-ja-foi-auto-suficiente-em-farinha-de-milho-arroz-

laranja-antes-dahttp://www.verdade.co.mz/tema-de-fundo/35-

themadefundo/58114-mocambique-ja-foi-auto-suficiente-em-farinha-de-milhoarroz-laranja-antes-da-

independencia?fb_comment_id=1024073184351382_1024296200995747

f5911f16bbdcfcindependencia?fb_comment_id=1024073184351382_10242962 00995747\#f591

1f16bbdcfc. Acesso realizado em 23/10/2018

OBSERVADOR. África do Sul, China e Índia são os principais parceiros comerciais de Moçambique. 26 de junho de 2018. Disponível em: https://observador.pt/2018/06/28/africa-do-sul-china-e-india-sao-osprincipaishttps://observador.pt/2018/06/28/africa-do-sul-china-e-india-sao-osprincipais-parceiros-comerciais-de-mocambique/parceiros-comerciais-democambique/ Acesso realizado em 24/10/2018

\section{Outros sites acessados:}

https://cipmoz.org/ http://omrmz.org/omrweb/ http://www.diagonal.net/a-diagonal/quem-somos 
http://www.iese.ac.mz/

http://www.jfs.co.mz/jfsweb/

http://www.mozambiquehistory.net/

http://www.vale.com/brasil/PT/Paginas/default.asp 


\section{Anexos}

I - Mapa administrativo de Moçambique

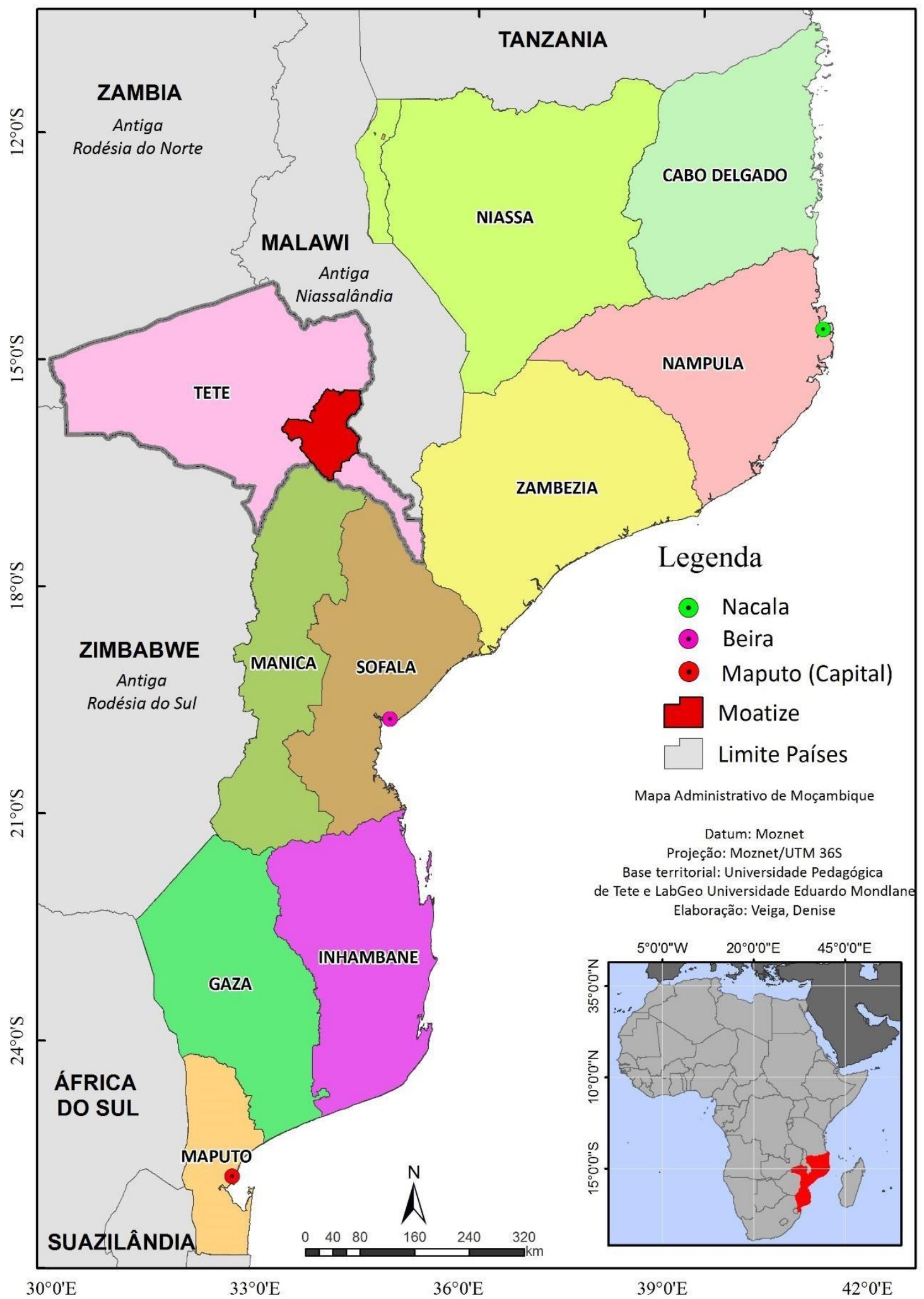


II - Mapa da Província de Tete, com destaque à Moatize e principais rios

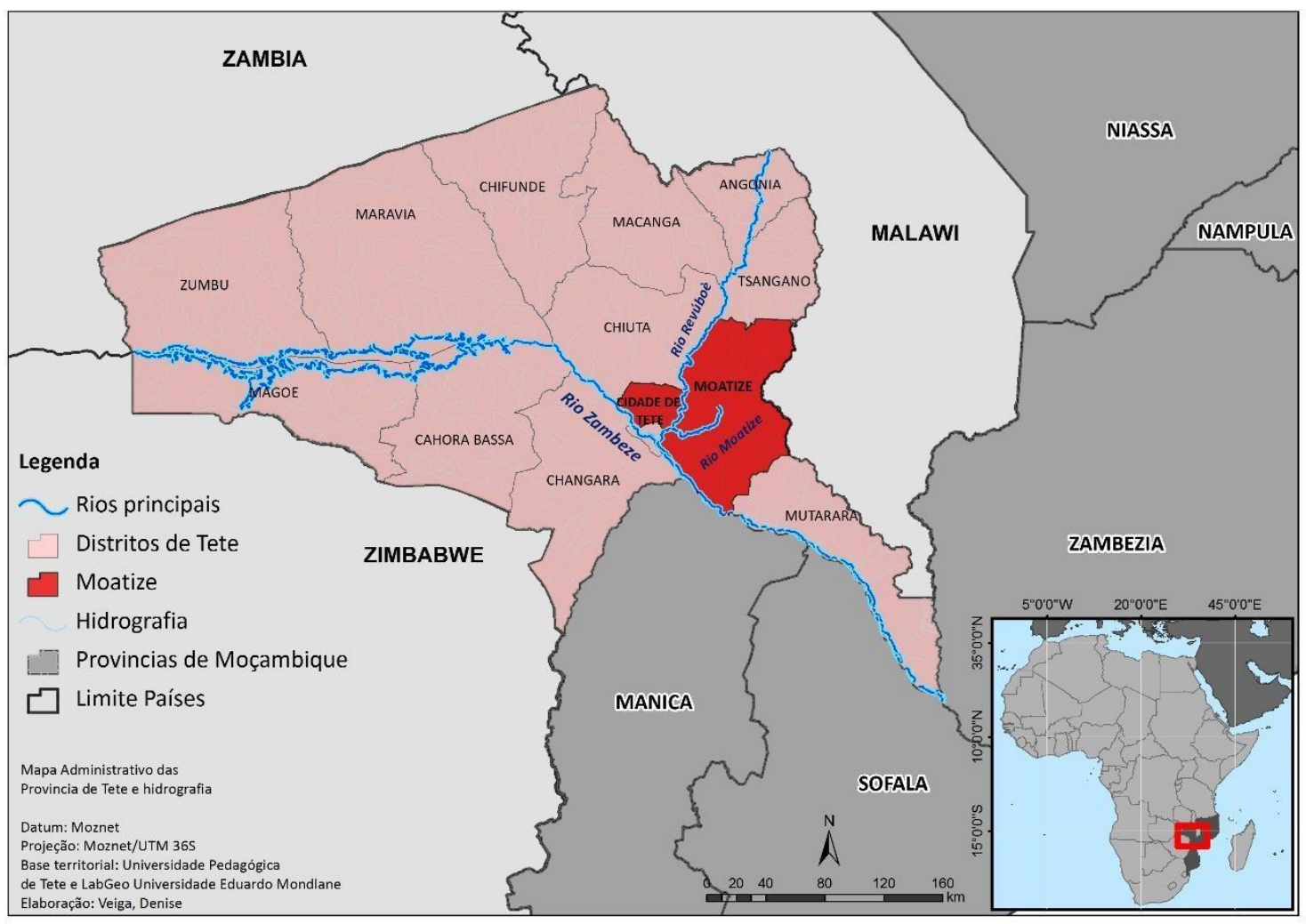




\section{III - Imagens aérea de Moatize}

\section{a) 2005}

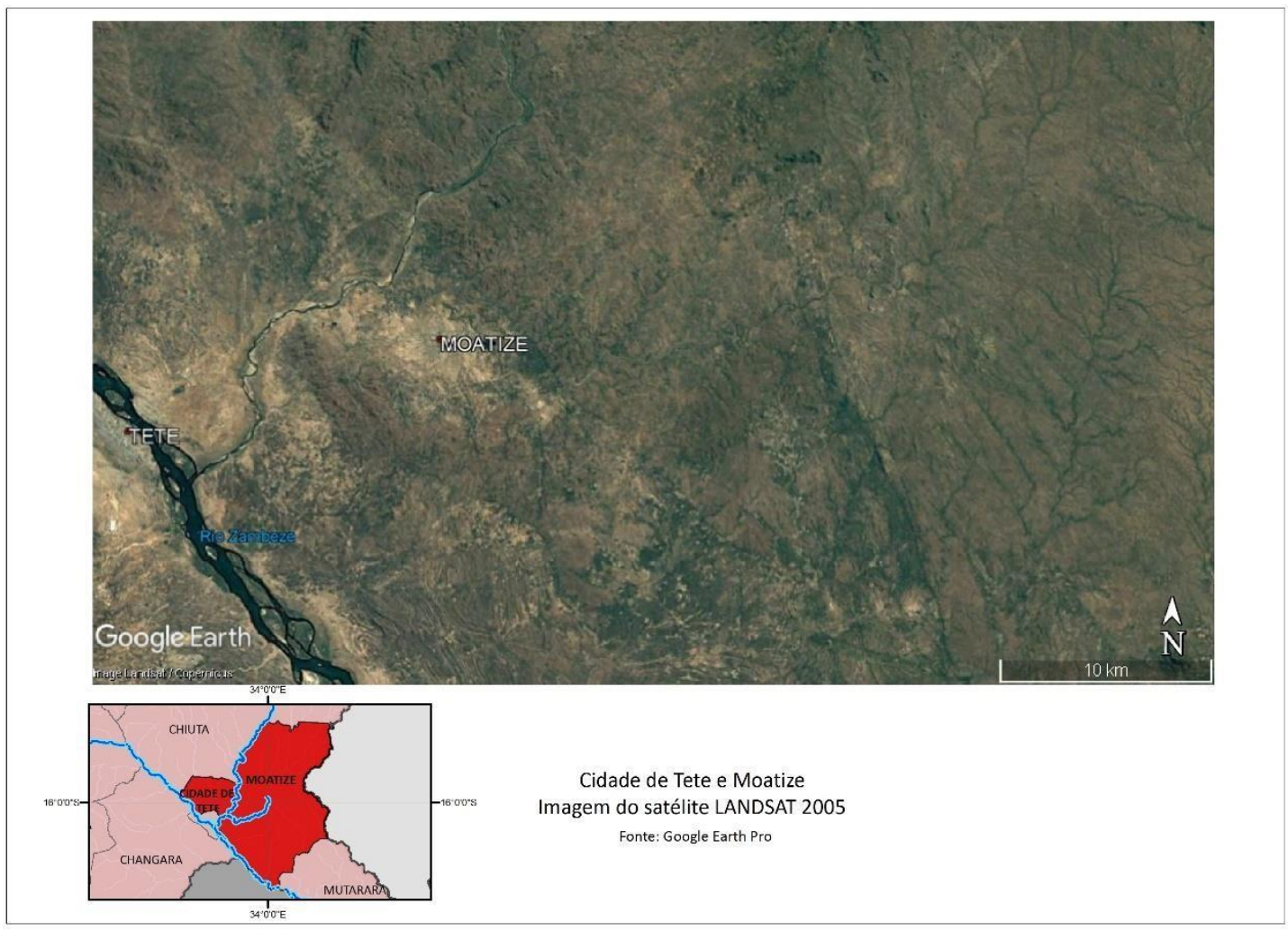

b) 2018

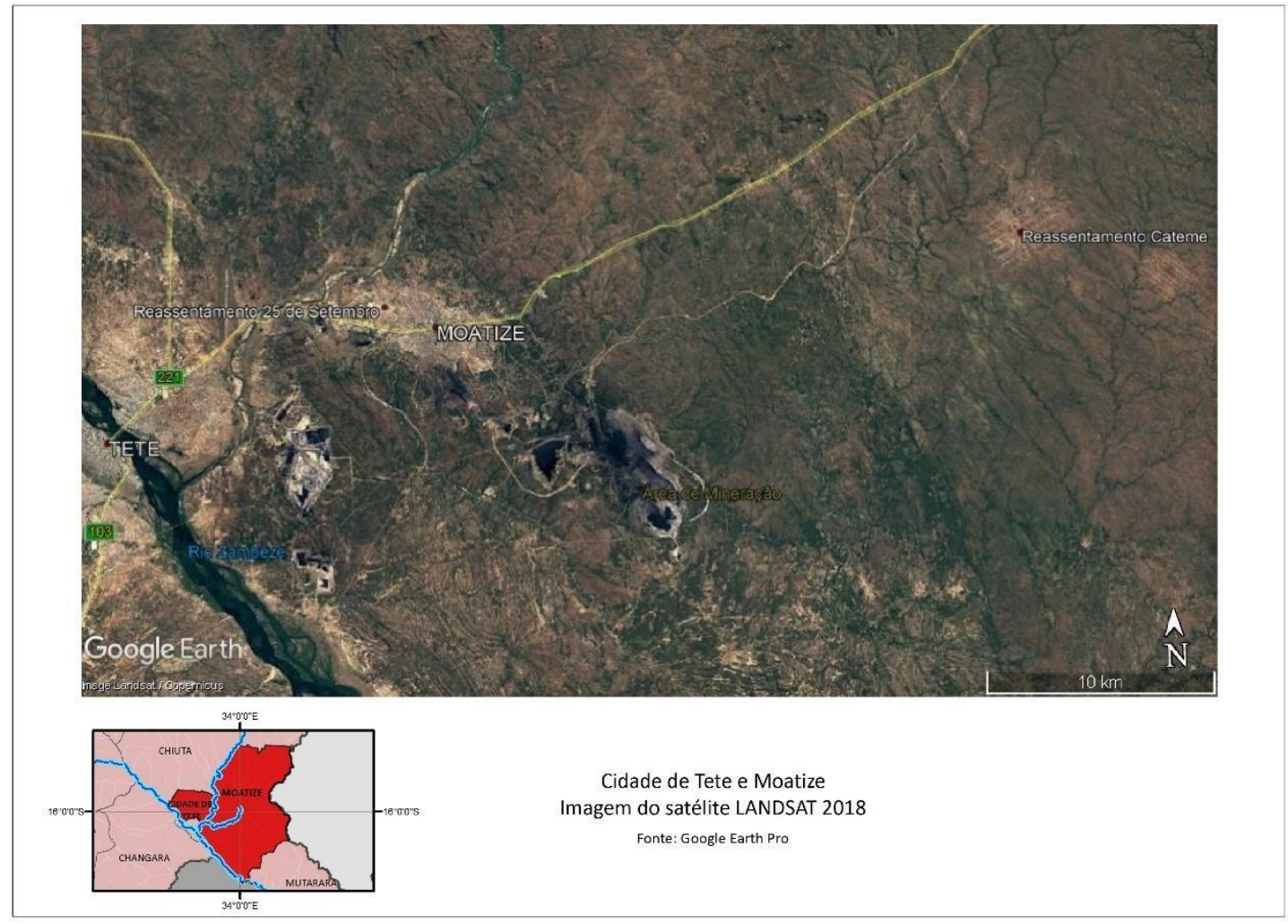


IV - Áreas de pesquisa, concessões e contratos de exploração dos mais variados minérios.

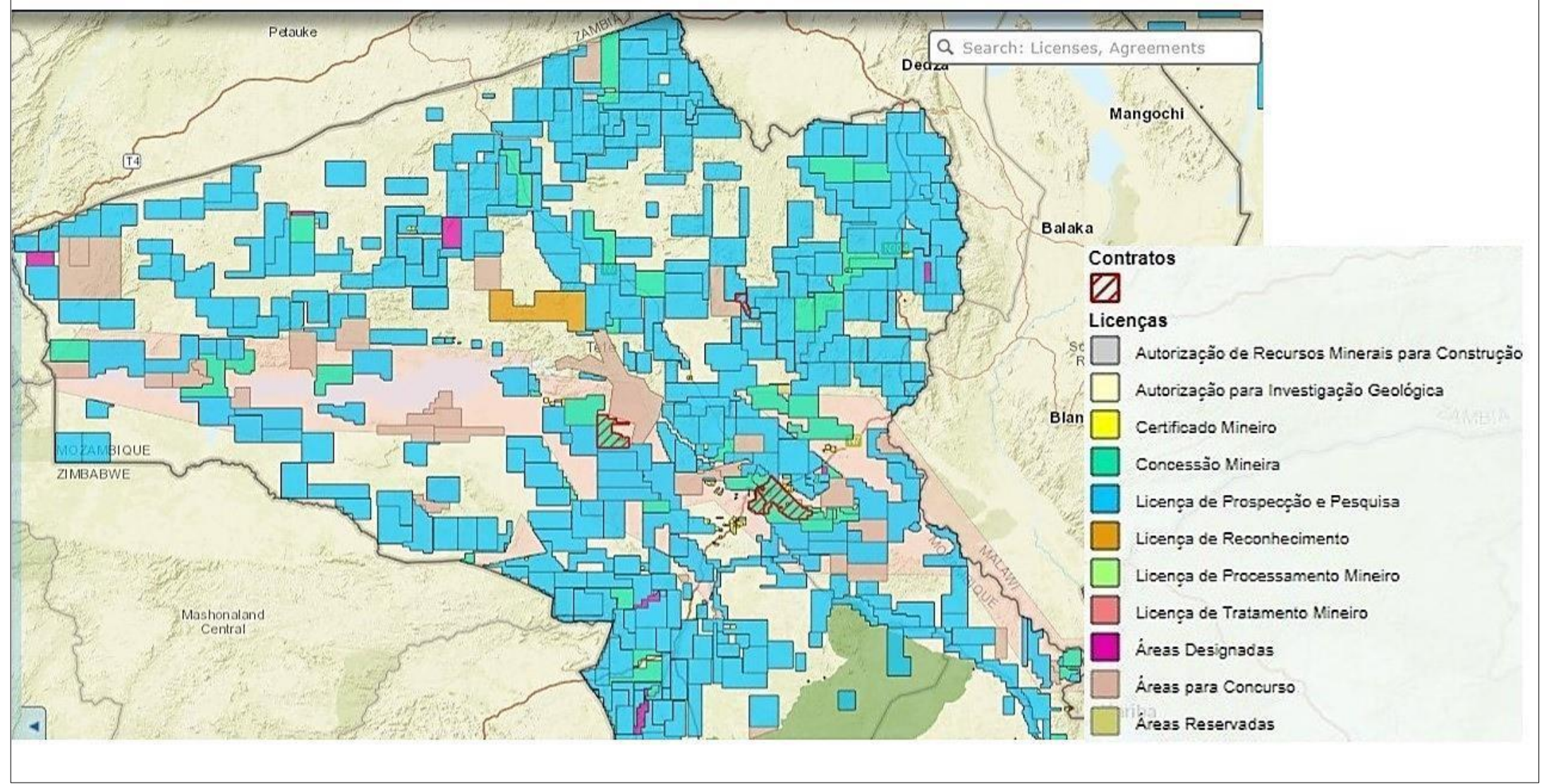

Fonte: http://portals.flexicadastre.com/mozambique/pt/ 